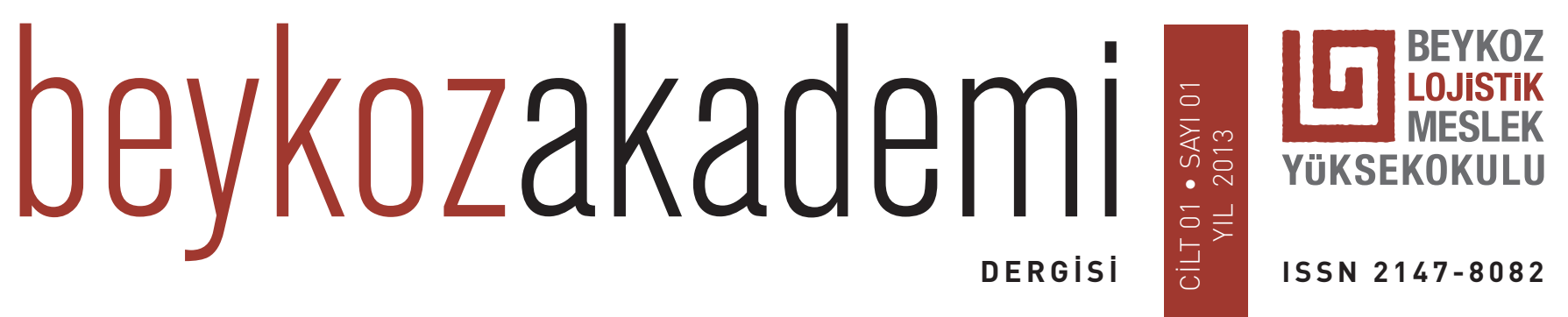




\section{içindekiler}

ÖRGÜTSEL ÖĞRENMENİN

LOJİSTÍK İŞLETMELERİNE ETKİLERİ

BİHTER KARAGÖZ, ALİ EKBER AKGÜN

KUZEY AFRİKA BÖLGESİNE LOJİSTİK

ÜS KURMANIN TÜRKİYE'NİN

ULUSLARARASI TİCARETI

AÇISINDAN ÖNEMİ

NURDAN ÖZYEDİERLER

SELECTION OF CONTAINER PORT

WITH FAHP-TOPSIS TECHNIQUE

İPEK EKER, AYFER ERGİN, GÜLER ALKAN 
TÜRKİYE'DE YAT VE MARÍNA İŞLETMECİİĞİ: İSTİHDAM DEĞERLENDİRMESİ İÇİN MEVCUT DURUM ANALİZİ GÖKÇE YÜKSEK

Fi̇zíKSEL AKTivíte VE SAĞLIKLI BESLENMENİN BİLİȘİM SEKTÖRÜNDE MASA BAŞINDA ÇALIŞANLARIN SAĞLIĞINA ETKİLERİNİN DEĞERLEMESİ BURCU GÜVEN

TÜM YÖNLERİYLE ESNEK ÇALIŞMA MODELLERİ YÜCEL ÖZTÜRKOĞLU 


\section{ÇIKARKEN}

İs hayatında yeni ihtiyaçların ve sorunların ortaya çıkması ile iktisadi ve idari bilimlerin bunları önce tanımlaması, ardından da yanıtlar üretmesi arasında daima bir gecikme süresi yașanıyor. Hatta doğrusunu söylemek gerekirse, hemen her zaman ortaya çıkan ihtiyaçlar ve sorunlar yine iș hayatı içerisinde çözülüyor ve ilgili bilim dalları sadece bu çözümleri bilimsel ve genele uygulanabilir bir biçim, bir sistematik kazandırıyor. Kușkusuz bu hız farkının temel sebebi bilimsel araștırma süreçlerinin gerektirdiği titizlik: bir șirket yöneticisi yalnızca elindeki sorunu, olabildiğince çabuk çözmeye odaklanabilirken; bir bilim insanı tek bir sorunu değil, en azından benzer sorunları da içeren bir sorun kümesini çözebilecek yöntemler geliștirmek durumunda. Yine de șahsi görüșüm iktisadi ve idari bilimlerin, bilhassa günümüzde en hızlı büyüyen, dolayısıyla en fazla sorun da üreten lojistik sektöründe iș hayatının ihtiyaç duyduğu üretkenliğin çok gerisinde kaldığı yönünde.

Bu sebeple bundan beș yıl önce Türkiye Lojistik Araștırmaları ve Eğitimi Vakfı olarak Beykoz Lojistik Meslek Yüksekokulu'nu kurduk. Bu kurumu olușturmaktaki temel amacımız, lojistik sektörünün en önemli sıkıntılarından biri olan nitelikli insan kaynakları ihtiyacına yanıt vermekti. Geçtiğimiz ay dördüncü mezuniyet törenini yapma mutluluğuna eriștiğimiz okulumuzda lojistik teması altında on üç ayrı programda eğitim veriyor ve gençlerimizi sektöre hazırlıyoruz. Diğer yandan, devam etmekte olan üniversite kuruluș çalıșmalarımızla, bu kamusal görevi çok daha geniş bir bağlamda ele alacağımız Beykoz Üniversitesi'nin hazırlığını yapıyoruz.

Illk sayısını elinizde tutmakta olduğunuz Beykoz Akademi hakemli dergisini, lojistik sektörünün ikinci bir eksiği olan, lojistik alanında yapılmıș akademik çalıșmaların sayısını ve kalitesini artırma; bu çalıșmaların paylașılacağı ortak bir platform olușturma iddiasıyla çıkartmıș bulunuyoruz. İtisadi ve idari bilimlerin tamamına, ancak özellikle lojistik bilim dalına dair gerek kuramsal, gerek ampirik, gerekse eleștirel çalıșmalara sayfalarını açacak olan dergimizin, bu alanda yürütülecek öncü tartıșmalara ev sahipliği yapması ve iș hayatı ile akademi arasında eğitimöğretim faaliyetimizin yanı sıra ikinci bir köprü olușturmasını hedefliyoruz.

$\mathrm{Bu}$, bir iddia olduğu kadar, bir de çağırıdır. Ben hem kendi adıma, hem de dergiye yazdıkları makaleler, yaptıkları titiz hakemlikler ve yayına hazırlamak için verdikleri emeklerle katkı koyan tüm arkadașlarımız adına, tüm akademisyenleri bu platformda bilimsel çalıșmalarını paylașmaya, tartıșmaya ve hepsinden önemlisi, inșa etmeye bașladığımız bu köprüyü güçlendirmeye davet ediyorum.

Alanında uzman ve güvenilir bilim insanları tarafından, tamamen șeffaf ve bilimsel etiğe bağlı hakemlik süreçleriyle yayın hayatına bașlamıș olan dergimizin ilk sayısını bu vesileyle ilginize sunuyorum.

RUHI ENGIN ÖZMEN

Beykoz Lojistik Meslek Yüksekokulu

Mütevelli Heyet Bașkanı 


\title{
ÖRGÜTSEL ÖĞRENMENİN LOJİSTİK İŞLETMELERİNE ETKİLERİ
}

\section{BİHTER KARAGÖZ (1), ALİ EKBER AKGÜN (2)}

\begin{abstract}
öz
Bu çalıșmada, lojistik ișletmelerinin öğrenme faaliyetlerine ağırlık vermeleriyle bașarılarının ne derece etkilendiğinin belirlenmesi amaçlanmıștır. Bu amaçla kavramsal bir model olușturulmuș ve dört araștırma hipotezi ampirik olarak incelenmiștir. İstanbul ilinde faaliyet gösteren UND (Uluslararası Nakliyeciler Derneği) üyesi lojistik ișletmelerinden elde edilen veriler analiz edilerek hipotezler test edilmiștir. Son bölümde ise araștırma sonuçları tartıșılmıștır. Araștırma sonuçları göstermiștir ki çalıșma, önceki araștırma sonuçlarını destekler niteliktedir ve örgütsel öğrenme ișletme performansını pozitif yönde etkilemektedir.
\end{abstract}

Anahtar Kelimeler: Lojistik, öğrenme, örgütsel öğrenme

JEL Kodları: D23, D83, L90

\begin{abstract}
The goal of this study is to determine how the success of the logistics companies was effected with they focused on learning activities. It Includes three main parts. For this purpose, a conceptual model is developed and four research hypotheses are emprically examined. Data obtained from member of UND logistics companies located in İstanbul have been analyzed to the test hypotheses. In thes last part, implications of research findings have been discussed. According to the findings of this study supported the results of previous research and possitive effects of organizational learning on business performance.
\end{abstract}

Keywords: Logistics, learning, organizational learning

JEL Codes: D23, D83, L90

1 Öğr. Gör., Namık Kemal Üniversitesi, Çerkezköy Meslek Yüksek Okulu, Lojistik Programı, Tekirdağ. bihterkaragozagmail.com

2 Prof. Dr., Gebze Yüksek Teknoloji Enstitüsü, İșletme Fakültesi, Strateji Bölümü, Kocaeli.

aakgundgyte.edu.tr 


\section{Giriș}

21. yüzyılın şekillenmesini sağlayacak üç temel bilim dalı “Gen Teknolojisi”, “Bilgi Teknolojisi” ve “Lojistik Hizmetler Yönetimi” olarak belirlenmiștir. İlk iki konu, 20. yüzyılda doğmuş daha çiçeği burnunda konular olmasına karşılık; lojistik taş devrinde de var olan, dünyanın en eski ișlerinden biridir. 20. yüzyılın son çeyreğinde bilgi teknolojisinde ve yönetim bilimlerinde sağlanan gelișmelerle gün ıșığına çıkmıș ve gerek üniversitelerde birer bilim dalı gerekse de endüstride bir uygulama alanı olarak görülmeye bașlanmıștır. İçinde yașadığımız çağın en hızlı gelișen ve en popüler sahası haline gelmiștir (Yıldıztekin, 2001). Elbette ki bu gelișime açık sektör, bilișim ve iletișim teknolojilerindeki yeniliklerden çok yakından etkilenmekte, bunun ıșığında sürekli değișmek ve kendini yenilemek zorundadır. 2000'li yılların bașına kadar ülkemizde sadece ürünlerin nakliyesi olarak düșünülen lojistik süreçleri; artan tüketici bilinci ve ihtiyaçlarıyla her geçen gün faaliyetlerine yenisini eklemekte, daha profesyonel ve etkin hizmetler sunmaya çalıșmaktadır. Teknolojide yașanan hızlı gelișimin etkisiyle, yoğun rekabet ortamının yaşandığı lojistik sektöründe müșteri istek ve ihtiyaçlarını karșılamak amacıyla organizasyonlar sürekli gelișim ve öğrenme prensibine karșı kayıtsız kalamamaktadır. Ünlü yönetim bilimci Peter Drucker “ișadamları yenilikçi örgütler kurmayı ve yönetmeyi öğrenmek zorundadır" demektedir. Yine dalın düșünce tekniğinin mimarı Daniel T. Jones'un “üst yönetim eğer yeniliklere açık değilse veya yeniliği rekabet edilebilir olmak için vazgeçilmez bir araç olarak görmek yerine, gelip geçici moda olarak ele alıyorsa, o ișletme en iyi stratejilere sahip olsa da olumlu sonuçlar alamaz (Dinçer, 2003: 167) sözü konunun çok boyutlu önemini göstermektedir.

Bu çalıșmada örgütsel öğrenmenin, lojistik hizmet kalitesi ve ișletme performansı üzerinde etkisinin olup olmadığı tespit edilmeye çalıșılmıștır.

\section{2. Öğrenme, Örgütsel Öğrenme ve Öğrenen Örgüt}

\section{1. Öğrenme}

Öğrenme, bilgi ve deneyim sonucu davranıșta olușan sürekli değișimdir. “Öğrenme genel olarak, bireyin davranıșlarında değișiklik yaratan, yeni bilgi ve anlayıș elde etme süreci veya bilgi ve becerilerin kazanılması süreci olarak tanımlanır. Bu tanımda bilginin tașıdığı iki farklı anlam bulunmaktadır" (Yazıcı, 2001: 64):

i. Beceri veya ișin nasıl yapıldığı bilgisinin (know-how) elde edilmesi ve bunun sonucunda bir olayı gerçekleștirme yeteneği,

ii. İșin yapılma amacını belirten bilginin (know-why) elde edilmesi yani bir tecrübe veya deneyin sonucunda olușan sonucu anlama ve kavramlaștırma yeteneği. 
“Algılamaları ve eski alıșkanlıkları kırmak oldukça zordur. Ancak, eğitim ve öğrenme şartları son $20 \mathrm{yıl}$ içinde çeșitli nedenlerle -uluslararası ișletmelerin meslek eğitimine zemin hazırlaması, çeșitlendirilmiș hizmetler ve artan düzenlemeler ile șekillenen yapılar, artan teknoloji kullanımı, artan kapasite kullanımı ve daha verimli hale gelen süreçler- değișiklik göstermiș ve günümüzde her büyüklükteki ișletmede zorunlu hale gelmektedir" (Wiley, 2005: 8).

\section{2. Örgütsel Öğrenme}

Örgütsel öğrenme ile ilgili çalıșmalar, “Cyert ve March’ın (1963) ilk kullanımıyla bașlamış olup, 1990'lı yılların bașında artış göstermiș (Grosan ve Guatto, 1996) ve yeni yüzyılda hala devam etmektedir (Bapui ve Crossan, 2004). Bu yapılan çalıșmalar, organizasyonların mevcut rekabet ortamında uyumlu yașayabilmesi için “sürekli gelișme" ve "sürekli iyileșme" zorunluluğunu ortaya koymuș ve bu özellikler, Goh ve Richards (1997) tarafından ilerletilmiștir" (Marshall vd., 2009: 37).

“Argyris ve Schon (1978) örgütsel öğrenmeyi eski ve yeni olarak ikiye ayırıp, eski örgütsel öğrenmeyi örgüt için ajanlar olarak bireylerin öğrenmesi hakkında olduğunu; yeni örgütsel öğrenmenin ise, Cook ve Yanow (1993) kollektif olarak ya da Brown ve Duguid (1991), Lave ve Wenger Wenger (1991), Richter (1998) sosyal varlıklar olarak insanlar tarafından gerçekleștirilen öğrenme olduğunu ifade etmektedir" (Ortenbland, 2001: 127). Schwandt ve Marquardt (1999) örgütsel öğrenmenin, performans ile öğrenmenin bütünleșme süreci olduğunu belirtmektedir (Gorelick, 2005: 384).

“Edward Deming'e göre, örgütsel öğrenme iki tür bilgiyi kapsamakta ve ortaya çıkmaktadır. Birincisi teknoloji, insan ve iş gereklerinin tanımlarıyla ortaya çıkan süreç bilgisi; ikincisi ise sistem teorisi, istatistik ve psikoloji gibi bilgilerden oluşan derinlemesine bilgidir. Birincisi, temel süreçler için gereken bilgiyi sağlarken, ikincisi de sorunlara çözümler bulunması ve süreçlerin geliștirilmesi için gerekli yöntemleri sağlamaktadır" (Bektaș, 2005: 23).

Örgütler, sadece öğrenen bireyler aracılığıyla öğrenir. Bireysel öğrenme, örgütün öğrenmesini garanti etmez. Ancak bireysel öğrenme olmadan da örgütsel öğrenme meydana gelmez (Senge, 2004: 155). "Örgütsel öğrenmenin gerçekleşebilmesi için, bireyin yașadığı olaylar sonucunda öğrendiklerini örgüte mal etmesi gerekmektedir” (Yazıcı, 2001: 95). Örgütsel öğrenme, bireysel öğrenme ile örgütsel öğrenme arasında kurulacak bir köprü sayesinde gerçekleșir. Bu köprünün kurulmasındaki önemli yapılar Şekil 1'de gösterilmektedir (Barutçugil, 2004: 152): 
Şekil 1:

Bireysel ve Örgütsel Öğrenme Arasındaki Köprü

\begin{tabular}{|l|l|l|}
\hline \multicolumn{1}{|c|}{ Bireysel Öğrenme } \\
- $\begin{array}{l}\text { Kişisel deneyimler } \\
\text { Zihinsel yapıda } \\
\text { değişim }\end{array}$ \\
$\begin{array}{l}\text { Deneme sonucu } \\
\text { oluşan davranış } \\
\text { değişiklikleri } \\
\text { Bireysel fikir ve } \\
\text { düşünceler }\end{array}$
\end{tabular}

Akademik literatür ve ișletme uygulamalarının çoğu örgütsel öğrenmenin, rekabet ortamını korumak için kritik yol olduğunu öne sürmektedir. Ayrıca literatür araștırmaları, örgütsel öğrenmenin çok yönlü ve karmașık bir konu olduğunu göstermektedir (Barutçugil, 2004: 38). Örgütsel öğrenmenin literatürdeki bazı tanımları șu șekilde yapılmaktadır:

Tablo 1:

Örgütsel Öğrenmenin Literatürdeki Tanımları

\begin{tabular}{|l|l|}
\hline Tanım & Yazar \\
\hline $\begin{array}{l}\text { Örgütsel öğrenme, hataları keșfetme ve düzeltme } \\
\text { sürecidir. }\end{array}$ & Argyris ve Schön, 1978. \\
\hline $\begin{array}{l}\text { Örgütsel öğrenme, çevre ve örgütsel faaliyetler } \\
\text { arasındaki ilișkiler hakkındaki bilgidir. }\end{array}$ & Daft ve Weick, 1984. \\
\hline $\begin{array}{l}\text { Örgütsel öğrenme, daha iyi bilgi ve anlayıș ile } \\
\text { faaliyetlerin iyileștirilmesi sürecidir. }\end{array}$ & Fiol ve Lyles, 1985. \\
\hline $\begin{array}{l}\text { Örgütsel öğrenme, organizasyonların davranıșlarına } \\
\text { yol gösteren rutinleri gösteren geçmișlerini } \\
\text { özümseyip, yorumlamalarıyla gerçekleșir. }\end{array}$ & Levitt ve March, 1988. \\
\hline $\begin{array}{l}\text { Örgütsel öğrenme, yenilik olușturmanın temel } \\
\text { sürecidir. }\end{array}$ & Stata, 1989. \\
\hline $\begin{array}{l}\text { Örgütsel öğrenme, açık fikirli sorgulamalar, bilgi } \\
\text { içeren yorumlamalar ve erișebilir hafızayı takip eden } \\
\text { süreçleri kapsar. }\end{array}$ & Day, 1991. \\
\hline $\begin{array}{l}\text { Örgütsel öğrenme, potansiyel davranıșlar dizisinde } \\
\text { değișime sebep olan bir bilgi ișlemesidir. }\end{array}$ & Huber, 1991. \\
\hline $\begin{array}{l}\text { Örgütsel öğrenme, örgütsel davranıșları } \\
\text { değiștirmektir. }\end{array}$ & Swieringa ve Wierdsma, 1992. \\
\hline $\begin{array}{l}\text { Örgütsel öğrenme, öz amaca ulașabilmek için } \\
\text { organizasyonun eriștiği ve kullandığı paylașılan } \\
\text { bilgiden olușan deneyimleri sürekli olarak test etmek } \\
\text { ve dönüștürmektir. }\end{array}$ & Mayer ve Dohm, 1992. \\
\hline $\begin{array}{l}\text { Örgütsel öğrenme, bireylerin hareketlerinin çevreyle } \\
\text { örgütsel etkileșimi yönlendirdiği döngüsellik olarak } \\
\text { adlandırılabilir. }\end{array}$ & Lee vd., 1992. \\
\hline
\end{tabular}




\begin{tabular}{|l|l|}
\hline $\begin{array}{l}\text { Örgütsel öğrenme, organizasyonun etkin faaliyet } \\
\text { gösterebilme kapasitesinin arttırılmasıdır. }\end{array}$ & Kim, 1993. \\
\hline $\begin{array}{l}\text { Örgütsel öğrenme, biri ya da diğerini vurgulayan } \\
\text { dinamik eğilimlerle yüzleșmede, gelișen yeni bilgi } \\
\text { ve mevcut yeteneklerden yararlanma ile rekabet } \\
\text { hedeflerini dengeleme problemi ile bașa çıkmaktır. }\end{array}$ & Levinthal ve March, 1993. \\
\hline $\begin{array}{l}\text { Örgütsel öğrenme, organizasyonun uzun dönemli } \\
\text { uyum sağlama kapasitesinin arttırılabilmesi için } \\
\text { organizasyondaki enformasyonu kullanılabilir bilgiye } \\
\text { dönüștürmeyi kolaylaștıran, süreçler, semboller, } \\
\text { aktörler ve eylemler sistemidir. }\end{array}$ & Schwandt, 1993. \\
\hline $\begin{array}{l}\text { Örgütsel öğrenme, davranıșı etkileyen potansiyele } \\
\text { sahip olan yeni bilgi ve sezgilerin geliștirilmesidir. }\end{array}$ & Slater ve Narver, 1994. \\
\hline $\begin{array}{l}\text { Güçlü ve kolektif olarak öğrenen ve sürekli olarak } \\
\text { kendini daha iyiye dönüștüren organizasyon; bașarı } \\
\text { için bilgiyi toplar, yönetir ve kullanır. }\end{array}$ & Marquardt,1996. \\
\hline
\end{tabular}

“Bu tür örgütler günümüzün hızla değișen, küreselleșen ve yoğunlașan rekabet ortamında, bilgi bulma, yaratma, içselleștirme ve bu bilgiyi karar ve davranışa yansıtmada, uygulamaya aktarmada yetenekli olușları nedeniyle en uygun düșünce ve yaklașım biçimine karşılık gelmektedirler" (Koçel, 1998: 339).

Örgütsel öğrenmeyi sağlamak için; “neyi bilmek gerektiği keșfedilmeli, bilinçsiz bilgisizlik alanları ortaya çıkarılmalı, ihtiyaç duyulan bilginin yeri belirlenmeli ve ihtiyaç duyulan bilgiyi olușturacak enformasyon ișe uygulanmalıdır" (Barutçugil, 2002: 154).

\section{Lojistik İșletmeleri}

\subsection{Lojistik ișletmeleri ve Türkiye'de lojistik}

Lojistik ișletmeleri, eșyanın tedarik noktasından nihai varıș noktasına kadar tüm bağlantılı tașıma, dağıtım, depolama, gümrük, sigorta vb. ișlemlerin etkin ve verimli biçimde yönetilmesini sağlayarak hizmet üreten organizasyonlardır. “Lojistik ișletmesi, șiddetli rekabet karşısında önceliklerini belirlemek durumundadır. Maliyet, kalite, hizmet ve esneklik eksenlerinde sürekli ilerlemek ve rakiplerinden bir adım önde olmak zorundadır. Yoğun rekabet ile birlikte bugünün lojistik ișletmeleri hangi operasyon türü olursa olsun müșterilerine en hızlı, en ekonomik ve en güvenilir çözümleri üretme becerisini göstermek durumundadır" (Erdal ve Saygılı, 2007: 5).

Dünya ticaretinde yașanan gelișmeler ve 1980 sonrası Türkiye'nin ihracata dayalı büyüme stratejilerini benimsemesi sonucu artan dıș ticaret hacmi, Türk lojistik sektörünün önemli adımlar atmasını sağlamıștır. Sağladığı gelișme sonrası kurumsal yapı ve altyapıdaki eksikliklere karșın Türkiye lojistik sektörü, bulunduğu coğrafyadaki mevcut ve potansiyel pazarlara hizmet verebilecek düzeylere erișmiștir. Rekabette lojistik hizmetlerin artan önemi ise lojistik sektörünü girișimciler açısından cazip bir yatırım alanı du- 
rumuna getirmiștir. Ulusal ve yerli birçok ișletme lojistik hizmeti verme yoluyla önemli adımlar atmıștır. Tüm bunların yanında uluslararası ve küresel ișletmeler Türkiye pazarına yönelmiș; satın alma, birleșme ya da doğrudan sermaye yatırımları ile sektörde rol almaya bașlamıștır (Gürdal, 2006: 48).

\subsection{Lojistik Ișletmelerinde Öğrenme Uygulamaları}

Joe Andraski Nabisco Entegre Lojistik ve Satıș İșletmesi'nin Stratejik Planlama Asbașkanı iken, "lojistik mesleğinin her beș yılda yeniden doğması gereklidir" demiștir. Bunun anlamı șudur ki, "gelecek 12 ay içerisinde lojistik ișletmesi kendi yetenek ve bilgilerinin \%20'sini güncelleștirmek ve yenisi ile değiștirmek zorundadır” (Trunick, 1995: 29).

Bilgi teknolojileri; bilgi sağlama desteği, bilgi yaratma ve iç görü paylașımı ile öğrenen örgütlerde kritik rol oynamaktadır. Lojistik ise bilgi teknolojisi uygulamaları ile gelișmektedir. Ancak lojistik uygulamalarında önemli bilgi sadece son kullanıcıdan gelmez, tedarik zinciri boyunca tüm așamalardan gelebilir. Bunun için çevre bir bütün olarak ele alınmalıdır (Drew ve Smith, 1998: 672).

Örgütsel öğrenme; öğrenme, örgüt içi bilgi paylașımı, paylașılan vizyon ve geniș düșünce arasında bağlantı olarak tanımlanırken lojistik ișletmelerinde müșteri ilișkilerinin geliștirilmesi ve hizmet etkinliğinin ilerletilmesi için ilișkisel değișim geliștirme olarak kavramlaștırılabilir. Bu ampirik önemli çıktı, örgütsel öğrenme ve organizasyon içi ilișki çalıșmalarında henüz ortaya çıkan yeni bir sonuçtur. Illișki geliștirmenin lojistik hizmetlerinin etkinliği üzerinde olumlu bir etkisi vardır. Lush ve Brown'ın (1996) değindiği gibi, çok kanallı ișletmelerin aralarındaki bilgi değișimi sayesinde birbirlerinin ihtiyaçlarına daha hızlı ve doğru bir șekilde cevap verebilmektedir. Baker ve Sinkula (1999) tedarik zinciri boyunca, öğrenme oryantasyonu ve ișletme performansı arasında (pazar payı, yeni ürün bașarısı ve tüm performans) pozitif yönlü bir ilișki olduğunu bulmuștur (Panayides, 2007b: 76).

Ampirik bulgular, lojistik hizmetlerin etkinliğinin işletmelerin ekonomik performansını etkilediğini de ortaya koymaktadır. Bu bulgular, Lambert ve Cooper (2000) ile Martin ve Grbac'ın (2003) tedarik zincirinde müșteri değeri yaratmanın, müșteri ihtiyaçlarına daha hızlı yanıt vermeyi sağlayacağını, Tan ve diğerlerinin (1998) de bu türlü bir müșteri değeri yaratılmasının ișletme performansını olumlu yönde etkileyeceğini belirtmesi ile desteklenmektedir (Panayides, 2007b: 77).

Drew ve Smith (1998) lojistik ișletmelerinde örgütsel öğrenme ile ilgili yaptığı çalıșmada tahmin edilmesi güç, zorlu iș çevresi ile karșı karşıya kalan organizasyonlar için stratejik karar verme lojistik içermesi ve örgütsel öğrenme ile entegre olma, yenilikçi stratejik yönetim ve uygulamaları benimsenme, değișim yöneticilerine (CCO) yer verme, 
mevcut yönetim uygulamaları ve öğrenme yeteneklerini güçlendirme, örgüt ikliminde yeniden yapılanma, değișime gönüllü olma ve hazır bulunma, öğrenme ve değișim için geçmiș hatalardan yararlanma ve bunun için örgütsel hafıza geliștirilmesi vb. önerilerde bulunmaktadır.

Ellinger, Ellinger ve Keller (2002) “Lojistik Yöneticilerinin Öğrenme Çevresi ve İșletme Performansı" üzerine yaptıkları çalıșmada, öğrenmenin lojistik performans üzerinde pozitif yönlü etkisi olduğunu belirtmiștir. Bu araștırmacılara göre, güncel araștırmalar lojistik ișletmelerinde bireysel seviyede öğrenme davranışlarına odaklanmaktadır. Gelecek araștırmalar, çoklu tedarik zinciri bölümlerindeki öğrenen örgüt kavramlarının incelemesine odaklanmalıdır (Ellinger vd., 2002: 33).

Örgütsel öğrenme; “tedarik zinciri ve ișletme performansı sonuçlarına (Hult vd., 2003) ile tedarikçi performansına (Carter, 2005) katkıda bulunduktan sonra tedarik zincirinde stratejik bir kaynak (Hult vd., 2003) olarak adlandırılmıștır" (Panayides, 2007a: 138).

Ratten (2004) “Lojistik İș Ortaklıklarında Öğrenme ve Bilgi Dağılımı” konulu çalıșmasında; gitgide küreselleșen pazarda ișletmelerin rekabet avantajı elde etmesinde iș ortaklıklarının önemini göstermekte, bunu bașarıyla uygulamaya geçirmede ișletmelerin her așamada birbiri ile gerçekleștireceği bilgi alıșveriși ve öğrenme oryantasyonun öneminden bahsetmektedir (Raten, 2004: 74).

Örgütsel öğrenme, lojistik hizmet sağlayıcıların yeteneklerini doğrudan etkilemekte ve lojistik hizmetlerin etkinliğini arttırmaktadır. Bu yapı Sekil 2'de kavramsal olarak gösterilmektedir (Panayides, 2007b: 69):

Şekil 2:

Lojistik İșletmelerinde Öğrenme Yapısı

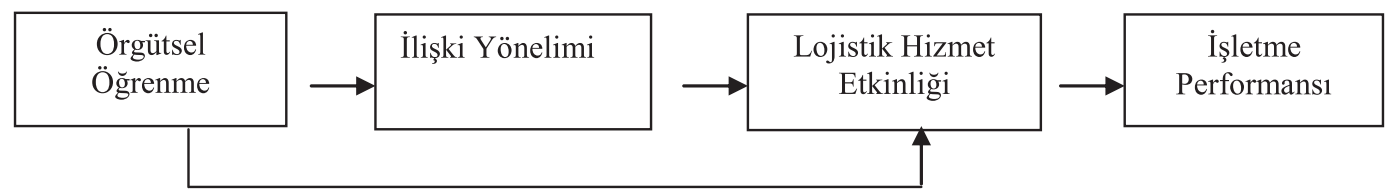

Panayides (2007) Lojistik Hizmet Sağlayıcıları üzerinde yaptığı incelemede bunlara ek olarak, organizasyon içi öğrenme yeteneği ile tedarik zinciri ilișkilerinin önemli ölçüde etkilendiğini bildirmiștir. Bu sonuç, lojistik hizmetlerin etkinliğini, dolayısıyla ișletme performansını geliștirmede ilișkisel yeteneğin ve örgütsel öğrenmenin önemine ișaret etmesiyle desteklenmekte; lojistik hizmet yöneticilerinin örgütsel öğrenme ve ilișki yönelimini, potansiyel olarak olumlu yönde etkilediğini vurgulamaktadır (Panayides, 2007b: 78). 


\section{Araștırmanın Hipotezleri}

Hipotezlerin olușturulmasında; Panayides'in çalıșmalarından (2007a, 2007b) yararlanılmıștır.

Pazarlama, yönetim ve strateji literatüründe örgütsel öğrenmenin ilișki yönelimi üzerindeki pozitif etkisi Argryis (1994), Levinthal ve March (1993) ve Sinkula (1994) araștırmaları tarafından desteklenmektedir. Örgütsel öğrenmede anahtar nokta, müșteri ihtiyaçları hakkında bilgi toplama yeteneğini içermesidir. Müșteri bilgilerini toplamak, müșterilerle daha yakın ilișki kurma ve empati geliștirme ile sağlanır (Panayides, 2007a: 138). Müșterileri ile yakın ilișki geliștiren ișletmeler, onları daha iyi tanıma ve özel hizmet sunma fırsatı yakalayacaktır. Zira, siparișin alınmasıyla bașlayan ilișkiler günümüz rekabet ortamında malın teslimi ile son bulmayarak geri lojistik faaliyetlerini de kapsayan bir süreç haline gelmiștir. Bu da iș ortaklıklarının veya anlașmalarının daha uzun vadeyi kapsamasına sebep olacaktır. Öğrenme, ișletmenin davranıșlarından birçoğunu değiștirecektir (Argyris, 1994). Öğrenme eğilimi, ișletme içinden müșterilere uzanan arenada çeșitli ilișki geliștirmelere (iletișim sıklığı, empati ve dürüstlük gibil dönüșecektir. Gelișen ilișkilerle tüm tedarik zinciri üyelerinin birbirleri ile veri ve belge alıșverișleri kolaylașacak, istedikleri anda ve hızda istenilen bilgiye ulașmaları sağlanacaktır. İstediği bilgiye istediği anda erișen müșteri de, alacağı hizmeti takip etme șansı yakalayacaktır.

\section{$H_{1}$ : Lojistik işletmelerinde örgütsel öğrenme, ilişki yönelimi üzerinde pozitif bir etkiye sahiptir.}

Bu ilișkinin, özellikle pazarlama kanalları üzerindeki performans uygulamalarını geliștirdiği (Jap, Manolis ve Weitz, 1999) saptanmıștır. Jap vd.'ne göre; tedarik zinciri üyeleri, ișbirliği halinde birer ortak gibi çalıștığında, bilgi adımı ve paylaşımını istekli gerçekleștirdiğinde etkinlik ve verimlilik artacaktır. Bu bağlamda, tedarik zincirinde tedarikçi ilișkilerini Hult ve Nicholos (1996); Mentzer vd., (2000, 2001) çalıșmıștır. “Örgütsel öğrenme, pazarda rekabetçi avantajı elde etmede gitgide stratejik bir araç haline gelmektedir" (Hult vd. 2000: 62). Selnes ve Sallis (2003); müșteri ve tedarikçi ilișkilerinin yakınlașması ile maliyet fazlalıklarının düștüğünü, kalitede, güvenirlikte, hızda ve esneklikte artışın sağlandığını tespit etmiștir. Yakınlaşan ilișki ile müșterilere yanıt verme hızı da artmaktadır (Martin ve Grbac, 2003). Lojistik hizmet sağlayıcıları ile müșterileri arasındaki yakın ilișki, ișlem maliyetlerinin düșüșüne de katkıda bulunmaktadır (Dyer, 1997). Lojistik sektörü, ișlem maliyetlerini kısarak satıcı ve alıcı bakıș açılarından uyumlu hale gelmelidir. Birbirlerine uyumlu hale gelen alıcı ve satıcı sistemleri ile hizmetlerdeki hata oranı da azalacaktır. Lojistik ișletmelerinin çıktılarını hız, güvenirlik, bulunurluk, vb. daha etkin ve verimli gerçekleștirmesi; müșterilerle olan ilișkilerinden etkilenmektedir. Öğrenme bu çıktılardaki değișkenliği azaltacak, verilen hizmetlerde standart kalite seviyeleri sağlanmasına yardımcı olacaktır. 


\section{$\mathrm{H}_{2}$ : Lojistik işletmelerinde örgütsel öğrenme, lojistik hizmet kalitesi üzerinde pozitif bir etkiye sahiptir.}

Çalıșmada daha önce de belirtildiği üzere, örgütsel öğrenme lojistik hizmet kalitesi üzerinde olumlu bir etkiye sahiptir. Bu ilișki Lukas vd. (1996) tarafından kavramsallaștırılmıștır. Buna ilave olarak örgütsel öğrenme ile ilgili yapılan diğer çalıșmalar da Hurley ve Hult (1998), Matsuno ve Mentzer (2000) rekabet avantajını sağlamada ve ișletme performansını geliștirmede birleșmektedir. Örgütsel öğrenmenin; ișletmenin yenilikçiliğini, yeni teknoloji ve süreçlere uyumunu etkilediği bulunmuștur (Calantone, Cavusgil ve Zhao, 2002). Celuch, Kasouf ve Peruvemba (2002), örgütsel yetenek üzerinde organizasyon içi öğrenme ilișkisinin etkilerini incelemiș ve öğrenmenin etkin bir bilgi sistemi geliștirmede esas teșkil ettiğini bulmuşlardır. Buna ek olarak, artan örgütsel öğrenme eğilimi ile daha güçlü sipariș gerçekleștirme, dıș ortaklıkların gelișimi, daha güçlü hizmet ve daha üstün yönetim yetkinliğinin sağlandığını da belirtmișlerdir. Yeni sistem ve süreçlere uyumluluk, lojistik hizmetlerin ulașımında etkinliğin artıșına sebep olmaktadır. Örgütsel öğrenme, lojistik hizmetlerin daha etkin sağladığı gibi uygulama maliyetlerini de düșürmektedir. Johnson ve Sohi (2003) öğrenmenin performansı arttırıcı pozitif çıktılar (etkinlik ve verimlilik gibi) ürettiğini saptamıștır. Yakınlaşan çalıșan ilișkileri, müșteriye cevap verme yeteneğini de geliștirecektir (Martin ve Grbac, 2003). Lojistik ișletmeleri ile müșterilerin ilișkileri; müșteri ihtiyaçlarının daha iyi anlașılmasına, verilen sözlerin zamanında yerine getirilmesine ve hizmet kalitesinin geliștirilmesine katkıda bulunacaktır.

\section{$\mathrm{H}_{3}$ : Lojistik ișletmelerinde ilișki yönelimi, lojistik hizmet kalitesi üzerinde pozitif bir etkiye sahiptir.}

Etkin bir tedarik zinciri, dolaylı veya dolaysız olarak çeșitli performans göstergeleri üzerinde katkıda sağlamaktadır (Choi ve Hartley, 1996). Tan, Kannan ve Hnadfield (1998), tedarik zincirinin tamamında müșteri değeri yaratmanın ișletme kârlılığı ve müșteri sadakati yaratma üzerinde pozitif etkisi olduğunu bulmuștur. Daha kaliteli lojistik hizmetlerinin gerçekleșmesi tedarik zinciri boyunca yenilik ve gelișimleri gerektirmektedir. Yüksek kalitede gerçekleșen lojistik hizmetler, ișletmenin performansı üzerinde etkili olacaktır. Lojistik hizmetlerin zamanında gerçekleșebilmesi ișletme performansından etkilenmektedir. Lojistik ișletmelerinde müșteri memnuniyeti; problem çözme yeteneği, tam kayıt tutma, tam zamanında teslimat ve müșteri memnuniyeti yaratma adına etkin bir iletișim sistemi (Leuthesser ve Kohli, 1995) ile sağlanmaktadır. Müșteri sadakati de (Innis ve La Londe, 1994) pazar payını arttırmaktadır. Bununla beraber, yüksek müșteri memnuniyeti ile ișletmenin ekonomik dönüșlerini hızlandıracak, pazar payı ve kârlılığını da (Anderson vd., 1994 ve Crosby vd., 1990) arttıracaktır. Daugherty vd. (1998) ve Stank vd. (2003) lojistik hizmet performansının (ulaşabilme, güvenirlik, hız) pazar payı üzerine etkisini tespit etmiștir. Tedarik zincirinde örgütsel öğrenmenin stratejik olarak 
kavramlaștırılması ise Hult vd. (2003) tarafından gerçekleștirilmiş olup, çalıșmaları sonucu örgütsel öğrenmenin tedarik zincirinde performans sonuçlarına katkıda bulunduğu sonucu tespit edilmiștir. Carter (2005) da örgütsel öğrenmenin, tedarikçi performansına katkı sağladığı sonucuna ulașmıștır. Çoğu zaman öğrenme, performansı geliștirir ve isteklerin açıkça bir arada paylaşılmasını sağlar. İsteklilik performansı belirlerken, performans da istekliliği etkiler (Hult vd., 2000: 62). Hizmetlerini sunarken ekip çalıșmasını benimseyen lojistik ișletmeleri, daha kaliteli hizmet çıktıları sağlayacaktır. Bu da ișletme performansını olumlu yönde etkileyecektir.

\section{$\mathrm{H}_{4}$ : Lojistik hizmet kalitesi, lojistik ișletmelerinin ișletme performansı üzerinde pozitif bir etkiye sahiptir.}

\section{Metodoloji}

\section{1. Ölçeklerin olușturulması}

Literatür gözden geçirilmiș, daha önce geliștirilmiș ve ölçekleri test edilmiş çalıșmalardan yararlanılmıștır. Tüm öğeler birden fazla ölçek ile ölçülmüștür. Örgütsel öğrenme; Sinkula, Baker ve Noordewier (1997) ve Hult ve Ferrell (1997a; 1997b) tarafından geliștirilen kavramlar kullanılarak ölçülmüștür. Bunlar öğrenme taahhüdü, paylașılan vizyon, açık fikirlilik ve işletme içi bilgi paylașımından olușmaktadır. Bu ölçek, daha sonraki çalıșmalara da uyarlanmıș (Calantone, Cavuşgil ve Zhao 2002; Jerez-Gomez, Cespedes-Lorente ve Vale-Cabrera 2005) güvenirliliği ve geçerliliği test edilmiștir. İlișki yönelimi ikinci derece faktör olarak; Sin vd. (2002) tarafından geliștirilen ölçek kullanılması benimsenmiștir. Bunlar; dürüstlük, ilișki kurma, iletișim, paylașılan değerler ve empatidir. Lojistik hizmet kalitesi; Mentzer, Flint ve Hult (2001) tarafından geliștirilen lojistik hizmet ölçeği kullanılarak ölçülmüștür (Panayides, 2007a: 140). İșletme performansı ise, Nick Bontis'in “Managing an Organizational Learning System by Aligning Stocks and Flows of Knowledge" (1999) bașlıklı tezinden yararlanılarak olușturulmuștur.

Araștırma hipotezlerini ölçmek amacıyla, literatüre dayalı olarak olușturulan ve uyarlanan ölçekler kullanılmıștır. Veri toplama için, anket yöntemi seçilmiștir. Bu ankette bașta Panayides (2007a)'den yararlanılmıș olup, kapalı uçlu ve 5'li Likert ölçeğinde (1 = Kesinlikle katılmıyorum, 2 = Katılmıyorum, 3 = Kararsızım, 4 = Katılıyorum, 5 = Kesinlikle katılıyorum.) sorulardan olușmaktadır.

Anket uygulaması sonucu elde edilen veri seti SPSS 19.0 istatistik paket programında analiz edilmiștir. Hipotezler, analizlerle ortaya çıkan sonuçlar doğrultusunda test edilmiștir. Yapılan analizler ve sonuçları aşağıda açıklanmıștır. 


\section{2. Örneklem}

Araștırmanın evreni olarak; Uluslararası Nakliyeciler Derneği'ne (UND) üye, İstanbul ilinde faaliyet gösteren, C2 (Ticari amaçla uluslararası ve yurtiçi eșya taşımacılığı yapacak gerçek ve tüzel kișilere verilen belge türü) yetki belgesine sahip 259 adet lojistik ișletmesi belirlenmiștir. Bu ișletmelerin orta ve üst düzey yöneticilerinden e-posta yoluyla ulaștırılan anket formalarının yanıtlanması istenmiștir. Kolayda örneklem yöntemi ile belirlenen 60 ișletme, araștırmanın örnek kitlesini olușturmaktadır. İlgili ișletmelere ait demografik bilgiler Tablo 2' de verilmiștir.

Tablo 2:

Araștırmaya Katılan İșletmelerin Demografik Özellikleri

\begin{tabular}{|c|c|c|}
\hline \multicolumn{3}{|c|}{ Hizmet Süresi Dağılımı } \\
\hline Yıl Sayısı & $f$ & $\%$ \\
\hline $1-10$ yıl arası & 11 & 18,3 \\
\hline $11-20$ yıl arası & 17 & 28,3 \\
\hline 21 - 30 yıl arası & 10 & 16,7 \\
\hline $31-40$ yıl arası & 12 & 20,0 \\
\hline 41 yıl ve üzeri & 10 & 16,7 \\
\hline \multicolumn{3}{|c|}{ Çalıșan Sayısı Dağılımı } \\
\hline Kiși Sayısı & $f$ & $\%$ \\
\hline 1 - 500 kiși & 26 & 43,3 \\
\hline 501 - 1000 kiși & 7 & 11,7 \\
\hline 1001 - 1500 kiși & 6 & 10,0 \\
\hline 1501 - 2000 kiși & 8 & 13,3 \\
\hline 2001 kiși ve üzeri & 13 & 21,7 \\
\hline
\end{tabular}

Araștırmaya katılan ișletmelerin hizmet süresi dağılımı incelendiğinde; \%18,3'ünün 1-10 yıl arası, \%28,3'ünün 11-20 yıl arası, \%16,7'sinin 21-30 yıl arası, \%20'sinin 31-40 yıl arası ve \%16,7'sinin ise 41 yıl ve üzeri süredir hizmet verdikleri görülmektedir. Çalıșan sayısı bakımından ise, \%43,3'ü 1-500 kiși arası, \%11,7'si 501-1000 kiși arası, \%10'u 1001-1500 kiși, \%13,3'ü 1501-2000 kiși ve \%21,7'si 2001 kiși ve üzeri olarak dağılım göstermektedir.

\section{Bulgular}

Katılımcıların örgütsel öğrenme yargılarına ilișkin görüşlerini ele almaya yönelik oluşturulan 15 yargı unsurunun belirli faktörler altında toplanıp toplanmadığını test etmek 
üzere faktör analizi yapılmıștır. Faktör analizine bașlamadan önce verilerin kendi içinde tutarlılığının olup olmadığını belirlemek için güvenilirlik analizi yapılmıștır. Güvenirlilik katsayısı (Cronbach-Alfa) 0,904 olarak belirlenmiștir. Hair vd. (1998)'ne göre ölçek güvenilirdir. Çalıșma öncesinde örgütsel öğrenme ölçeğinin 4 alt boyutta toplanabileceği düșünülmüș olup, yapılan faktör analizi sonucunda söz konusu ölçeğin 3 faktör altında (Faktör 1: Öğrenme taahhüdü ve açık fikirlilik, Faktör 2: Paylașılan vizyon, Faktör 3: İșletme içi bilgi paylașımı) toplanabildiği görülmüștür. Tüm faktörler toplam varyansın \%65, 57'sini açıklamaktadır (KMO, 0,774; Barlett testi: 532,023; $p<0,000$ ).

Katılımcıların ilișki yönelimi yargılarına ilișkin görüșlerini ele almaya yönelik olușturulan 17 yargı unsurunun belirli faktörler altında toplanıp toplanmadığını test etmek üzere de faktör analizi yapılmıștır. Faktör analizine başlamadan önce verilerin kendi içinde tutarlılığının olup olmadığını belirlemek için güvenilirlik analizi yapılmıștır. Güvenirlilik katsayısı (Cronbach-Alfa) 0.947 olarak belirlenmiștir. Bu kritere göre ölçek güvenilirdir. Çalıșma öncesinde ilișki yönelimi ölçeğinin așağıdaki gibi 5 alt boyutta toplanabileceği düșünülmüș olup, yapılan faktör analizi sonucunda söz konusu ölçeğin 3 faktör altında (Faktör 1: Paylașılan değer ve empati, Faktör 2: İlișki kurma ve doğruluk, Faktör 3: İletișim) toplandığı görülmüștür. Tüm faktörler toplam varyansın \%74,75'ini açıklamaktadır (KM0, 0,823, Barlett's testi: 998,703; $p<0,000$ ).

Katılımcıların örgütsel öğrenme, ilișki yönelimi, hizmet kalitesi ve performans yargılarına ilișkin görüșleri incelendiğinde;

Tablo 3:

Örgütsel Öğrenme ölçeğine İlișkin Betimleyici İstatistikler

\begin{tabular}{|l|l|l|}
\hline Yargılar & Ort. & SS \\
\hline Geçmișten alınan birçok ders ișletmenin hayatta kalmasını sağlamaktadır. & 4,3000 & 0,76579 \\
\hline $\begin{array}{l}\text { İsletmemizde öğrenme, örgütün yașamını sürdürmesi için gerekli } \\
\text { görülmektedir. }\end{array}$ & 4,1833 & 0,89237 \\
\hline İșletmemizin temel değeri, gelișimi anahtar faktör olarak kabul etmektir. & 4,0833 & 1,01333 \\
\hline $\begin{array}{l}\text { İșletmemizde, iș görenlerin eğitimi birer harcama olarak değil yatırım aracı } \\
\text { olarak kabul edilmektedir. }\end{array}$ & 4,0833 & 1,02992 \\
\hline $\begin{array}{l}\text { İșletmemizde bilgi paylașımının önemi üst düzey yönetim tarafından tekrar } \\
\text { tekrar vurgulanmaktadır. }\end{array}$ & 4,0167 & 1,08130 \\
\hline Kendi karar ve faaliyetlerimizi sürekli olarak değerlendiririz. & 3,9833 & 1,03321 \\
\hline Paylașılan vizyon, ișletmemizin temel amacıdır. & 3,8833 & 0,88474 \\
\hline Daima bașarısız örgütsel çabaları analiz ederiz ve öğrenilen dersleri aktarırız. & 3,8667 & 1,03280 \\
\hline Yaptığımız ișle ilgili varsayımlara dayalı eleștirileri yansıtırken korku duymayız. & 3,8000 & 1,14685 \\
\hline $\begin{array}{l}\text { Yöneticilerimiz, rekabetçi avantajı yakalamada örgütsel öğrenmenin anahtar } \\
\text { faktör olduğunu kabul etmektedir. }\end{array}$ & 3,7000 & 1,04638 \\
\hline
\end{tabular}




\begin{tabular}{|l|l|l|}
\hline $\begin{array}{l}\text { İșletme personeli pazardaki yerlerini anlamak için sürekli olarak sorgulama } \\
\text { yapmaktadır. }\end{array}$ & 3,6833 & 1,11221 \\
\hline $\begin{array}{l}\text { İșletmemizin tüm kademe, fonksiyon ve bölümlerinde toplam kabul } \\
\text { görmektedir. }\end{array}$ & 3,6500 & 0,86013 \\
\hline Tüm çalıșanlar, ișletmemizin amaçlarına büyük önem vermektedir. & 3,5333 & 1,08091 \\
\hline $\begin{array}{l}\text { İșletmemiz yönetim çizelgesinde, çalıșanlar yöneticilere iș ortağı gibi } \\
\text { gösterilmektedir. }\end{array}$ & 3,0333 & 1,13446 \\
\hline $\begin{array}{l}\text { Örgütsel aktivitelerden öğrenilen derslerin departmandan departmana } \\
\text { paylașımını sağlayan özel bir düzeneğe sahibiz. }\end{array}$ & 3,0333 & 1,19273 \\
\hline
\end{tabular}

Örgütsel öğrenme ölçeği incelendiğinde katılımcıların yargılar içerisinde yüksek katılım yargının 4,30 yanıt ortalaması ile "Geçmișten alınan birçok ders ișletmenin hayatta kalmasını sağlamaktadır" olarak șekillendiği görülürken, en düșük katılım düzeyine sahip yargı ise 3,03 yanıt ortalaması ile "İșletmemiz yönetim çizelgesinde, çalıșanlar yöneticilere iș ortağı gibi gösterilmektedir" ve "Örgütsel aktivitelerden öğrenilen derslerin departmandan departmana paylașımını sağlayan özel bir düzeneğe sahibiz" biçiminde șekillenmiștir.

Tablo 4:

İlișki Yönelimi Ölçeğine İlișkin Betimleyici İstatistikler

\begin{tabular}{|l|l|l|}
\hline Yargılar & Ort. & SS \\
\hline Temaslarımızı sürekli tutmaya çalıșırız. & 4,4167 & 0,71997 \\
\hline İșletmemizin geçmiș iș ilișkilerine baktığımızda güvenilir olduğunu görürüz. & 4,3833 & 0,73857 \\
\hline Uzun dönemli ilișkiler kurmak için çabalarız. & 4,3167 & 0,70089 \\
\hline Yakın ișbirliği halinde çalıșmalarımızı sürdürürüz. & 4,1500 & 0,89868 \\
\hline Görüșlerimizi sıklıkla birbirimize iletebiliyoruz. & 4,0500 & 0,76856 \\
\hline İlișkilerimiz dürüstlük üzerine kuruludur. & 3,8500 & 0,95358 \\
\hline İșletmemiz çalıșanlarına karșı dürüst davranır. & 3,8500 & 0,97120 \\
\hline Birbirimize karșı her zaman dürüst davranırız. & 3,8500 & 1,00549 \\
\hline Her iletișim yoluyla memnuniyetsizliğimizi iletebiliyoruz. & 3,6667 & 0,96843 \\
\hline Aynı ortak değerlere sahibiz. & 3,5833 & 1,01333 \\
\hline Birbirimizin neler hissettiğini anlayabiliyoruz. & 3,4500 & 1,15605 \\
\hline Birbirimizin değer ve hedeflerini anlayabiliyoruz. & 3,3500 & 1,10200 \\
\hline Olaylara birbirimizin bakıș açısından bakabiliyoruz. & 3,2667 & 1,16250 \\
\hline Birbirimizin düșünceleri için endișelenebiliyoruz. & 3,2167 & 1,19450 \\
\hline Aynı dünya görüșüne sahibiz. & 3,1667 & 1,02786 \\
\hline Birçok șey hakkında ortak düșünceyi paylașıyoruz. & 3,1667 & 1,04422 \\
\hline Etrafımızdaki olaylara karșı aynı duyguları hissederiz. & 3,1000 & 0,91503 \\
\hline
\end{tabular}


İlișki yönelimi ölçeği incelendiğinde katılımcıların yargılar içerisinde yüksek katılım yargının 4,41 yanıt ortalaması ile "temaslarımızı sürekli tutmaya çalıșırız" olarak șekillendiği görülürken, en düșük katılım düzeyine sahip yargı ise 3,10 yanıt ortalaması ile “Etrafımızdaki olaylara karșı aynı duyguları hissederiz” biçiminde șekillenmiștir.

Tablo 5:

Hizmet Kalitesi Ölçeğine İlișkin Betimleyici İstatistikler

\begin{tabular}{|l|l|l|}
\hline Yargılar & Ort. & SS \\
\hline Hizmetlerimiz güvenirlik özelliğine sahiptir. & 4,4500 & 0,64899 \\
\hline Dokümantasyonlar doğru olarak olușturulmaktadır. & 4,4500 & 0,76856 \\
\hline İșletmemiz sorun çözme yeteneğine sahiptir. & 4,4333 & 0,67313 \\
\hline Bilgiler doğru olarak iletilmektedir. & 4,3333 & 0,79547 \\
\hline Hizmetlerimiz zamanında cevap verebilme yeteneğine sahiptir. & 4,2000 & 1,03825 \\
\hline Hizmetlerimiz tam zamanında gerçekleștirilebilmektedir. & 4,1500 & 0,86013 \\
\hline İșletmemiz, kullanıcıları için empati kurabilme yeteneğine sahiptir. & 4,0333 & 0,88234 \\
\hline
\end{tabular}

Hizmet kalitesi ölçeği incelendiğinde katılımcıların yargılar içerisinde yüksek katılım yargının 4,45 yanıt ortalaması ile "Hizmetlerimiz güvenirlik özelliğine sahiptir" ve "Dokümantasyonlar doğru olarak olușturulmaktadır” olarak șekillendiği görülürken, en düsükk katılım düzeyine sahip yargı ise 4,03 yanıt ortalaması ile "İșletmemiz, kullanıcıları için empati kurabilme yeteneğine sahiptir" biçiminde șekillenmiștir.

Tablo 6:

İșletme Performansı Ölçeğine İlișkin Betimleyici İstatistikler

\begin{tabular}{|l|l|l|}
\hline Yargılar & Ort. & SS \\
\hline Ekibimiz ișletmemize güçü katkı sağlamaktadır. & 4,5833 & 0,61868 \\
\hline İșletmemiz sağlık sektöründe oldukça saygın bir yere sahiptir. & 4,4833 & $0 ., 65073$ \\
\hline Ekibimizin çalıșmaları takım halinde gerçekleșmektedir. & 4,4333 & 0,69786 \\
\hline İșletmemiz müșterilerin ihtiyaçlarını karșılayabilmektedir. & 4,4000 & 0,86749 \\
\hline Ekibimiz performans hedeflerini karșılamaktadır. & 4,3000 & 0,67145 \\
\hline İșletmemizi bașarılı buluyorum. & 4,2500 & 0,72778 \\
\hline İșletmemiz çalıșanları kendi performanslarından memnundur. & 4,1833 & 0,85354 \\
\hline İșletmemizin gelecek performansı için kușku duymuyorum. & 4,1000 & 0,89632 \\
\hline İșletmemiz çalıșanları burada olmaktan mutludur. & 3,8500 & 1,05485 \\
\hline İșletmemiz çalıșanları burada çalıștıkları için memnundur. & 3,8333 & 1,02786 \\
\hline
\end{tabular}

Performans ölçeği incelendiğinde katılımcıların yargılar içerisinde yüksek katılım yargının 4,58 yanıt ortalaması ile "Ekibimiz ișletmemize güçlü katkı sağlamaktadır" 
olarak șekillendiği görülürken, en düșük katılım düzeyine sahip yargı ise 3,83 yanıt ortalaması ile "İșletmemiz çalıșanları burada çalıștıkları için memnundur" biçiminde șekillenmiștir.

\section{$\mathbf{H}_{1}$ Hipotezinin Testi}

Bu aşamada ilișki yönelimi, bağımlı değișken olarak ele alınmıș ve örgütsel öğrenme düzeyinin, bağımlı değișken skorlarındaki değișimi hangi düzeyde yordadığı Tablo 7'de sunulan regresyon sonuçları ile irdelenmiștir.

Tablo 7:

İlișki Yönelimi ve Örgütsel Öğrenmeye İlișkin Regresyon Analizi

\begin{tabular}{|l|l|l|l|l|l|}
\hline & \multicolumn{2}{|l|}{$\begin{array}{l}\text { Standartlaștırılmamıs } \\
\text { Katsayılar }\end{array}$} & $\begin{array}{l}\text { Standartlaștırılmıs } \\
\text { Katsayılar }\end{array}$ & t & p \\
\hline & B & S. Hata & Beta & & \\
\hline Sabit & 1,258 & 0,429 & & 2,931 & 0,005 \\
\hline Örgütsel Öğrenme & 0,643 & 0,112 & 0,603 & 5,764 & 0,000 \\
\hline \multicolumn{7}{|l|}{ Model Özeti } & \multicolumn{7}{|l|}{ Düzeltilmiș $\mathbf{R}^{2}$} & S $_{\mathbf{x}}$ & \\
\hline $\mathbf{R}$ & $\mathbf{R}^{2}$ & 0,353 & 0,57481 & \\
\hline 0,603 & 0,364 &
\end{tabular}

$(F=33,219)$

Tablo 7'deki bulgular incelendiğinde, örgütsel öğrenmenin ilișki yönelimi üzerindeki etkisinin anlamlı olduğu görülmektedir $(p<0,05)$. Örgütsel öğrenme düzeyindeki 1 birimlik artıș, ilișki yönelimi düzeyinde 0,643 birimlik artışa yol açmaktadır. Illișki yönetimi düzeyindeki değişimin \%36,4'ü örgütsel öğrenme tarafından açıklanmaktadır. Bașka bir deyișle, lojistik ișletmelerinde örgütsel öğrenme, ilișki yönelimi üzerinde pozitif bir etkiye sahiptir. Bu sonuçlara göre, $\mathrm{H}_{1}$ hipotezinin kabul edildiği görülmektedir.

\section{$\mathrm{H}_{2}$ Hipotezinin Testi}

Hizmet kalitesi bağımlı değișken olarak ele alınmıș ve örgütsel öğrenme düzeyinin, bağımlı değișken skorlarındaki değișimi hangi düzeyde yordadığı Tablo 8'de sunulan regresyon sonuçları ile irdelenmiștir. 
Tablo 8:

Hizmet Kalitesi ve Örgütsel Öğrenmeye İlișkin Regresyon Analizi

\begin{tabular}{|l|l|l|l|l|l|}
\hline & \multicolumn{2}{|l|}{$\begin{array}{l}\text { Standartlaștırılmamıs } \\
\text { Katsayılar }\end{array}$} & $\begin{array}{l}\text { Standartlaștırılmıs } \\
\text { Katsayılar }\end{array}$ & t & p \\
\hline & B & S. Hata & Beta & & \\
\hline Sabit & 1,776 & 0,429 & & 4,738 & 0,000 \\
\hline Örgütsel Öğrenme & 0,664 & 0,112 & 0,667 & 6,817 & 0,000 \\
\hline \multicolumn{7}{|l|}{ Model Özeti } & Düzeltilmiș $\mathbf{R}^{2}$ & $\mathbf{S}_{\mathrm{x}}$ & \\
\hline $\mathbf{R}$ & $\mathbf{R}^{2}$ & 0,50176 & \\
\hline 0,603 & 0,445 & 0,435 & & \\
\hline
\end{tabular}

$(F=46,473)$

Tablo 8'deki bulgular incelendiğinde, örgütsel öğrenmenin hizmet kalitesi üzerindeki etkisinin anlamlı olduğu görülmektedir $(p<0,05)$. Örgütsel öğrenme düzeyindeki 1 birimlik artıș, hizmet kalitesi düzeyinde 0,664 birimlik artıșa yol açmaktadır. Hizmet kalitesi düzeyindeki değișimin \%44,5'i örgütsel öğrenme tarafından açıklanmaktadır. Bașka bir deyişle, lojistik ișletmelerinde örgütsel öğrenme, lojistik hizmet kalitesi üzerinde pozitif bir etkiye sahiptir. Bu sonuçlara göre, $\mathrm{H}_{2}$ hipotezinin kabul edildiği görülmektedir.

\section{$\mathrm{H}_{3}$ Hipotezinin Testi}

Bu așamada hizmet kalitesi bağımlı değișken olarak ele alınmıș ve ilișki yönelimi düzeyinin, hizmet kalitesindeki değișimi hangi düzeyde yordadığı Tablo 9'da sunulan regresyon sonuçları ile irdelenmiștir.

Tablo 9:

İlișki Yönelimi ve Hizmet Kalitesine İlișkin Regresyon Analizi

\begin{tabular}{|l|l|l|l|l|l|}
\hline & \multicolumn{2}{|l|}{$\begin{array}{l}\text { Standartlaștırılmamıs } \\
\text { Katsayılar }\end{array}$} & $\begin{array}{l}\text { Standartlaștırıııı } \\
\text { Katsayılar }\end{array}$ & t & p \\
\hline & B & S. Hata & Beta & & \\
\hline Sabit & 1,945 & 0,338 & & 5,746 & 0,000 \\
\hline Örgütsel Öğrenme & 0,635 & 0,090 & 0,680 & 7,064 & 0,000 \\
\hline \multicolumn{7}{|l|}{ Model Özeti } & $\mathbf{R}^{2}$ & Düzeltilmiș $\mathbf{R}^{2}$ & S $_{\mathrm{x}}$ & \\
\hline $\mathbf{R}$ & 0,462 & 0,453 & 0,49374 & \\
\hline 0,680 &
\end{tabular}

$(F=49,896)$ 
Tablo 9' daki bulgular incelendiğinde, ilișki yöneliminin hizmet kalitesi üzerindeki etkisinin anlamlı olduğu görülmektedir $(p<0,05)$. İlișki yönetimi düzeyindeki 1 birimlik artıș, hizmet kalitesi düzeyinde 0,635 birimlik artışa yol açmaktadır. Hizmet kalitesi düzeyindeki değișimin \%46,3'ü ilișki yönelimi tarafından açıklanmaktadır. Bașka bir deyișle ilișki yöneliminin, hizmet kalitesi üzerinde pozitif bir etkiye sahiptir. Bu sonuçlara göre, $\mathrm{H}_{3}$ hipotezinin kabul edildiği görülmektedir.

\section{$\mathrm{H}_{4}$ Hipotezinin Testi}

Lojistik ișletmelerinde hizmet kalitesinin performansı hangi düzeyde yordadığı Tablo 10 'da sunulan regresyon sonuçları ile incelenmiștir.

Tablo 10:

Performans ve Hizmet Kalitesine İlișkin Regresyon Analizi

\begin{tabular}{|l|l|l|l|l|l|}
\hline & \multicolumn{2}{|l|}{$\begin{array}{l}\text { Standartlaștırılmamıs } \\
\text { Katsayılar }\end{array}$} & $\begin{array}{l}\text { Standartlaștırılmıs } \\
\text { Katsayılar }\end{array}$ & t & p \\
\hline & B & S. Hata & Beta & & \\
\hline Sabit & 1,535 & 0,345 & & 4,444 & 0,000 \\
\hline Örgütsel Öğrenme & 0,630 & 0,080 & 0,721 & 7,926 & 0,000 \\
\hline \multicolumn{7}{|l|}{ Model Özeti } & $\mathbf{R}^{2}$ & Düzeltilmiș $\mathbf{R}^{2}$ & S $_{\mathbf{x}}$ & \\
\hline $\mathbf{R}$ & 0,520 & 0,512 & 0,40794 & \\
\hline 0,721 &
\end{tabular}

$(F=62,818)$

Tablo 10'daki bulgular incelendiğinde, performasın hizmet kalitesi üzerindeki etkisinin anlamlı olduğu görülmektedir $(p<0,05)$. Hizmet kalitesi düzeyindeki 1 birimlik artış, performans düzeyinde 0,630 birimlik artıșa yol açmaktadır. Performans düzeyindeki değișimin \%52'si hizmet kalitesi tarafından açıklanmaktadır. Bașka bir deyișle performans, hizmet kalitesi üzerinde pozitif bir etkiye sahiptir. Bu sonuçlara göre, H4 hipotezinin kabul edildiği görülmektedir.

\section{Sonuç ve Değerlendirme}

Rekabetin hız kazandığı günümüzde dünyayla bütünleșme yönündeki gereklilik, ișletmeleri bu yapıya uymak zorunda bırakmaktadır. Bu doğrultuda öğrenme, ișletmelerin rekabet edebilirlikleri için sahip olmaları gereken önemli faktörlerden bir tanesi olmaktadır. İșletmeler öğrenme sürecine büyük önem göstermeli; öğrenmeye daha çok yatırım yapmalı ve tüm çalışanları içerecek şekilde düzenlemeler yapmalıdır. 
Lojistik ișletmelerinin öğrenme faaliyetlerine ağırlık vermeleriyle beraber, başarılarının ne derecede etkilendiğinin belirlenmesi ana amacıyla gerçekleștirilen bu araștırmada; “Örgütsel öğrenme ile lojistik hizmet kalitesi ve ișletme performansı arasında pozitif bir etki vardır" hipotezini destekleyecek bulgular elde edilmeye çalıșılmıștır. Bunun sonucunda, öğrenme sürecini benimseyen ve öğrenmeye gereken duyarlılığı gösteren lojistik ișletmelerinin davranıșlarının değiștiği, ișletmelerin genel olarak daha kaliteli hizmetler sağladığı, bunun da ișletme performansını arttırdığı ortaya çıkmıștır. Bu sonuç daha önce yapılan araștırma sonuçları (Panayides 2005, Panayides 2007b) ile paralellik göstermektedir.

Bu çalıșmadaki sonuçlar seçilen örneklem ile sınırlandırılmıștır. Daha sonraki çalıșmalarda diğer derneklere üye lojistik ișletmeleri de dikkate alınarak araștırma genișletilebilir. Ayrıca bu çalıșma için yapılan literatür taramamaları esnasında, Türkiye'de lojistik ișletmelerinde örgütsel öğrenme faaliyetlerine ilișkin araștırmaların çok kısıtlı yapı ve sayıda olduğu görülmüștür. Bu araștırmaların sayısının arttırılması hem ilgili literatürün genișlemesi hem de sektörünün daha da gelișmesi açısından faydalı olacaktır.

\section{KAYNAKÇA}

Argyris, Chris ve Donald A. Schön (1978) Organizational Learning: A Theory of Action Perspective, London: Addison-Wesley.

Barutçugil, İsmet (2002) Bilgi Yönetimi, 2.Baskı, İstanbul: Kariyer.

Barutçugil, İsmet (2004) Stratejik Insan Kaynakları Yönetimi, İstanbul: Kariyer.

Bektas, Cetin (2005) Işletme Becerilerive Grup Calıșması, Afyon: Afyon Eğitim Sağlık ve Bilimsel Araștırma Vakfı.

Bontis, Nick (1999) Managing An Organizational Learning System By Aligning Stocks and Flows of Knowledge An Empirical Examination of Intellectual Capital Knowledge Management and Business Performance, basılmamıs doktora tezi, Kanada: University of Western Ontario.

Carter, Craig R (2005) “Purchasing Social Responsibility and Firm Performance: The Key Mediating Roles of Organisational Learning and Supplier Performance"; International Journal of Physical Distribution \& Logistics Management, 35(3/4), s.177-194.

Calantone, R J; S Tamer Cavușgil ve Yushan Zhao (2002) “Learning Orientation, Firm Innovation Capability and Firm Performance"; Industrial Marketing Management, 31, s.515-524. 
Dinçer, Ömer ve Yahya Fidan (2003) Ișletme Yönetimine Giriș, 6. Baskı, İstanbul: Beta.

Drew, Stephen A. W. ve Peter A. C. Smith (1998) “The New Logistics Management Transformation Through Organizational Learning"; International Journal of Physical Distribution \& Logistics Management, 28(9/10), s.24-33.

Ellinger, Alexander E., Andrea D. Ellinger ve Scott B. Keller (2002) “Logistics Managers” Learning Environments and Firm Performance"; Journal of Business Logistics, 23(1), s.19-38.

Erdal, Murat ve Mehmet Sıtkı Saygılı(2007) Lojistik Ișletmelerinde Yönetim Organizasyon ve Filo Yönetimi, İstanbul: UTIKAD.

Eren, Erol (2001) Örgütsel Davranış ve Yönetim Psikolojisi, 7.Baskı, İstanbul: Beta.

Gorelick, Carol (2005) “Organizational Learning vs. the Learning Organization: A Conversation with a Practitioner"; The Learning Organization, 12(4), s.383-388.

Gürdal, Sahavet (2006) Türkiye Lojistik Sektörü Altyapı Analizi, İstanbul: İstanbul Ticaret Odası.

Hair, Joseph F., Ronald L. Tatham, Rolph E. Anderson ve William Black (1998) Multivariate Data Analysis, 5th Edition, New Jersey: Prentice Hall.

Huber, George P (1991) “Organizational Learning: The Contributing Processes and the Literatures"; Organization Science, 2, s.88-115.

Hult, G. Tomas M. ve O. C. Ferrell (1997) “A Global Learning Organization Structure and Market Information Processing"; Journal of Business Research, 40(2), s.155-166.

Hult, G. Tomas M., Ernest L. Nicholas, Larry C. Giunipero ve Robert F. Hurley (2000) "Global Organizatonal Learning in the Supply Chain: A Low Versus High Learning Study"; Journal of International Marketing, 8(3), s.61-83.

Koçel, Tamer (2004) Işletme Yöneticiliği, 6.Baskı, İstanbul: Beta.

Levinthal, Daniel A. ve James G. March (1993) "The Myopia of Learning"; Strategic Management Journal, 14, s.95-112.

Marshall, Joe, Simon Smith ve Steve Buxton (2009) “Learning Organizations and Organizational Learning: What Have We Learned”; Management Services, 53(2), s.36-44. 
Mentzer, John T., Daniel J. Flint ve Tomas M. Hult (2001) “Logistics Service Quality as a Segment-Customized Process"; Journal of Marketing, 65(4), s.82-104.

Ortenbland, Anders (2001) “On Differences Between Organizational Learning and Learning Organization"; The Learning Organization, 8(3), s.125-133.

Panayides, Photis M. (2007a) "Effects of Organizational Learning in the Third Party Logistics"; Journal of Business Logistics, 28(2), s.133-158.

Panayides, Photis M. (2007b) “The Impact of Organizational Learning on Relationship Orientation, Logistics Service Effectiveness and Performance"; Industrial Marketing Management, 36(1), s.68-80.

Ratten, Vanessa (2004) “Learning and Information Dissemination in Logistics Alliance"; Asia Pasific Journal of Marketing and Logistics, 16(4), s.65-81.

Senge, Peter M. (2004) Beșinci Disiplin Öğrenen Organizasyon Düșünüșü ve Uygulaması, 12. Baskı, İstanbul: Yapı Kredi.

Sin, Leo Y. M., Alan C. B. Tse, Oliver H. M. Yau, Jenny S. Y. Lee ve Raymond Chow (2002) “The Effect of Relationship Marketing Orientation on Business Performance in a Service-Oriented Economy"; Journal of Services Marketing, 16(7), s.656-676.

Sinkula, James M., Wiiliam E. Baker ve Thomas Noordewier (1997) “A Framework for Market-Based Organizational Learning: Linking Values, Knowledge and Behaviour"; Journal of the Academy of Marketing Science, 25(4), s.305-318.

Stata, R. (1989) “Organizational Learning The Key to Management Innovation"; Sloan Management Review, 30(3), s.63-74.

Trunick, Perry A. (1995) "How Do You Build Value"; Transportation \& Distribution, 36(12), s.29.

Wiley, Sandra (2005) "Transforming Your Firm! The Learning Culture of the Best"; Infotech Update, 14, s.8-11.

Yazıcı, Selim (2001) Öğrenen Organizasyonlar, İstanbul: Alfa.

Yıldıztekin, Aytekin (2001) “Lojistiğin Tanımı", http://atillayildiztekin.com/dergi_ve_ gazete_yazilari, Erișim tarihi: 12.11.2011 


\title{
KUZEY AFRİKA BÖLGESİNE LOJİSTİK ÜS KURMANIN TÜRKİY'NİN ULUSLARARASI TICARETI AÇISINDAN ÖNEMİ
}

NURDAN ÖZYEDİERLER ${ }^{(1)}$

\begin{abstract}
ÖZ
Bu çalıșmada Türkiye'nin Kuzey Afrika ve Ortadoğu bölgesi ile ticareti ve Mısır'a neden bir lojistik üs kurulması gerektiği anlatılmıștır. Son yıllarda Türkiye'nin dünyada güçlü bir ekonomi olarak anılmasında ihracatının büyük bir payı vardır. Türkiye büyüme ve gelișmesini sürdürebilmek için ihracatını daha da arttırmak zorundadır. Bu nedenle lojistik üslere ihtiyacı olacaktır. Lojistik üslerin sadece ülke sınırlarında değil yurtdıșında da kurulmasıyla hem maliyetler düșürülebilir hem de daha uzak pazarlara ulașılabilir. Bu kapsamda daha önceden yapılmış çalıșmalardan yararlanılarak kurulum yeri olarak Mısır düșünülmüștür. Dolayısıyla Mısır'a kurulacak bir lojistik üssün Türkiye'nin ticaretine yükselen bir ivme kazandıracağı ve bölgesel bağımlılığı azaltacağı öngörülmektedir. Anahtar Kelimeler: Küresel ticaret, lojistik üs (merkez), Ortadoğu ve Kuzey Afrika, Türkiye JEL Kodları: L90, L91, N90
\end{abstract}

\begin{abstract}
This article is about Turkey's trade with the Middle East and North Africa region and why it is important to build a logistic base in Egypt. Recently, export has had a big role to play in bolstering Turkey's position in the world. Turkey has to increase its exports in order to grow further. That's why it needs new logistic bases. These bases should not be built only at home but also abroad to cut costs and to enable the country to reach distant markets. In this respect, considering the previous studies made in this field, Egypt is thought to be a good location for a new base to be built. It has been predicted that building a new base in Egypt will help Turkey's export grow in the region and help lessen Turkey's dependence on other countries.
\end{abstract}

Keywords: Global trade, logistic base (center), Middle East and North Africa, Turkey JEL Codes: L90, L91, N90

1 İstanbul Ticaret Üniversitesi, Sosyal Bilimler Enstitüsü, Uluslararası Ticaret Bölümü nurdanozyedierler@ggmail.com 


\section{Giriș}

Gelișen dünya ekonomilerinde sürdürülebilir bir ekonomik büyüme sağlanabilmesi için dıș ticaret bir zorunluluktur. Ülkeler varlıklarını sürdürebilmek, dış ödemeler dengesizliklerini engellemek ve iktisadi kalkınma sağlamak gibi nedenlerle dış ticarete ihtiyaç duymaktadırlar. Uluslararası rekabetin son yüzyılda artması nedeniyle ülkeler daha zorlu bir rekabet içine girmișlerdir. Bu rekabette üstünlük sağlayabilmek için küresel ve bölgesel iș birlikleri yaratmaya çalıșmıșlardır. Bu sebeple ülkeler Avrupa Birliği (AB), Körfez İșbirliği Konseyi, Güneydoğu Asya Uluslar Birliği (ASEAN), Orta Amerika Topluluğu, Karadeniz Ekonomik İșbirliği Örgütü (KEI), Kuzey Amerika Ülkeleri Serbest Ticaret Anlașması (NAFTA), Avrupa Serbest Ticaret Birliği (EFTA) gibi yapılar ve Serbest Ticaret Anlașmaları (STA) olușturmuşlardır. Bu ekonomik topluluklar ve ekonomik ișbirliği anlașmaları bir yandan ülkelerin ticaretlerini geliștirmelerine olanak sağlarken, diğer taraftan da o ülke ya da ülke gruplarına bağımlılıklarının artırmalarına neden olmaktadır. Örneğin; Türkiye'nin ihracatında AB'nin payı 2012 yılında \%38,83 düzeyinde gerçekleșmiștir (TÜIKK, 2013: 1). Bu durumda ihracatını yoğun gerçekleștirdiği bir ülke ya da bölgede ortaya çıkacak ekonomik kriz Türkiye ekonomisini de doğrudan etkileyebilmektedir. Bu nedenle 2008 yılında Amerika Birleșik Devletleri'nde bașlayıp Avrupa'yı saran ekonomik krizden Türkiye de etkilenmiștir. Bundan kurtulmanın yolu bölgesel bağımlılığı engelleyecek yeni pazarlara yönelmek ve ulașım ağını güçlendirmekten geçer.

Günümüzde gelișmiș ve gelișmekte olan ülkeler küresel ekonominin nimetlerinden en iyi şekilde yararlanabilmek için yeni yapılacak STA'lar ile serbest bölgeler ve pazarlara daha hızlı ve daha uygun maliyetlerle ulașılabilmesini sağlayacak lojistik üslere önem vermișlerdir. Türkiye de bu önemin farkına varmıș, ulașım yollarını geliștirmeye, yenileme çalıșmaları yapmaya, yurtiçi ve yurtdıșı lojistik merkezler kurmaya bașlamıștır. Bu çalıșmaların devamında yurt içinde Mersin ve Samsun'da lojistik üslerin kurulumuna ilișkin yasal süreç ve alt yapı hazırlıkları devam etmekte, yurtdıșında da Rusya ve Suriye'de lojistik merkez kurulum çalıșmaları devam etmektedir.

Türkiye coğrafi konumu itibariyle doğu ile batı arasında bir köprü ve doğal bir lojistik üs konumundadır. Bu nedenle kara, deniz, hava ve demiryolu ulaștırma koridorlarına gereken önemi vermelidir. Bu koridorlar ile ticaretine yeni bir yön vererek sadece köprü olmanın ötesine geçebilir ve yüzünü $A B$ dıșındaki ülkelere de dönebilir. Böylelikle Türkiye'ye tarihsel bağlarla bağlı ülkelerle dıș ticaretini geliștirebilir. Dolayısıyla bu çalıșmanın ana hatlarını, tarihsel bağlarla bağlı olduğu Ortadoğu ve Kuzey Afrika ülkeleri ve bunlarla ikili ticaret düzeyleri olușturmaktadır. Türkiye'nin bu bölgeler ile olan ticaret hacmi son yıllarda artmaya bașlamıștır. TÜlK verilerine göre 2006 yılında Kuzey Afrika'ya olan ihracat 3,09 milyar dolar iken bu rakam 2012 yılında 9,44 milyar dolara çıkmıștır (TÜIK, 2013: 1). Bu artıșın daha yükselen bir seyir olușturulabilmesi için aynı bölgede ticaret hacminin yoğun olduğu ülkelerin belirlenmesi, lojistik üs ve ticaret mer- 
kezi olabilecek noktaların kararlaștırılması ve gerekli alt yapı hizmetlerinin sağlanarak, lojistik merkezlerin kurulması önem arz etmektedir.

Lojistik üs kurulum yeri seçilirken bütün ulaşım modlarına yakın olması ve alt yapının yeterli olması gibi önemli kriterlere dikkat edilmelidir. Dünyada daha önce yapılan lojistik üsler incelendiğinde ağırlıklı olarak deniz, kara ve demiryolu bağlantısının olması lojistik üsten daha fazla verim alınmasını sağladığı sonucuna ulașılmıștır. Bu açıdan en önemli lojistik üslere Rotterdam, Singapur ve Şanghay limanları örnek gösterilebilir. Türkiye'de bu büyüklükte limanlar bulunmamakla birlikte hali hazırda Trabzon, Mersin, İzmir, Tekirdağ ve İstanbul'da önemli lojistik limanları bulunmaktadır. Türkiye'nin dünya ekonomisindeki yeri ve büyüklüğü arttıkça limanlarının uluslararası ticaretteki önemi de artacaktır. Türkiye'nin ticaret hacmindeki gelișmeler dikkate alındığında, bölgesel bağımlılığını azaltacak lojistik merkezlere ihtiyacı olduğu açıktır. Kuzey Afrika bölgesinde kurulacak bir lojistik üssün Türkiye'nin dıș ticaretine ne gibi katkılar sağlayacağı bu araștırmanın asıl amacını olușturmaktadır.

Bu kapsamda çalıșmada öncelikle bu alanda yapılmıș literatür çalıșmaları incelenmiștir. Yapılan çalıșmalardan farklı olarak yurtdıșında lojistik üs kurmanın ticarete etkisinin incelemesi açısından literatüre katkı sağlamaktadır. Araștırmanın üçüncü bölümünde Türkiye'nin genel ve bölgesel dıș ticareti analiz edilmiș, dördüncü bölümde ise lojistik üs kavramı irdelendikten sonra lojistik üs kurulum yeri olarak Mısır'ın seçilmesinin nedenleri detaylandırılmıștır.

\section{Literatür}

Türkiye'nin dünya ticaretindeki yeri, bölgedeki ülkelerle ticaret potansiyeli ve ekonomik anlașmaların ticaretine etkileri üzerine yapılan çalıșmalarla ilgili açıklamalara aşağıda kısaca değinilmiștir.

\subsection{Uluslararası ticaret, ülke potansiyelleri ve ülkeler arası anlașmalar alanında yapılan çalıșmalar}

Dıș Ticaret Müsteșarlığı'nda olușturulan bir komite, gelecek dönemlerde gerçekleștirilecek pazara giriș faaliyetlerinin yoğunlașacağı ülkelerin tespiti amacıyla pazarın büyüklüğü, alım gücü düzeyleri, yatırımlar ve enerji politikaları gibi kriterleri göz önünde bulundurarak hedef ve öncelikli ülkeleri belirlemiștir (DTM, 2010: 162-167)

Dıș ticarette ülke potansiyelleri ile yapılan bir diğer çalıșma Karagöz ve Karagöz (2009) tarafından Çekim Modeli kullanılarak yapılan çalıșmadır. Bu çalıșmada kültürel ve tarihsel yakınlık, nüfus büyüklüğü, uzaklık ve GSMH gibi kriterler dikkate alınmıș ve Türkiye'nin küresel ticaretinde potansiyel arz eden ve potansiyelin üstünde ticaret yapılan 
ülkeler belirlenmiștir.

Genç vd. (2011) de Karagöz ve Karagöz gibi çekim modelinden faydalanmıș, bu sefer daha bölgesel bir çalıșma yapılmıș ve “Karadeniz Ekonomik İșbirliği Bölgesinde Ticaret Akımlarının Belirleyicileri"ni incelemișlerdir. Çalıșmalarında, ihracatçı ve ithalatçı ülkelerin gayri safi yurt içi hâsılaları ve ülke nüfuslarının bölgedeki ticaret akımlarını pozitif olarak etkilediğini tespit etmiștir. Ayrıca, üye ülkelerin bașkentlerinin birbirine olan uzaklığı, ticaret akımlarını negatif olarak etkilerken, ülkelerin ortak sınıra sahip olmaları ve aynı dili konușmalarının ticaret akımlarını pozitif olarak etkilediği sonucuna varılmıștır.

Özkaya (2011) da “ikili ve Çok Taraflı Anlașmaların Türkiye'nin İhracatı Üzerindeki Etkisi” ile ilgili yaptığı çalıșmasında çekim modeli ile Türkiye'nin ihracatında ikili anlașmaların etkili olmadığını, Gümrük Birliği (GB) anlașması dıșında Türkiye'nin taraf olduğu çok taraflı anlașmaların Türkiye'nin ihracatı üzerinde istatistiksel olarak anlamlı pozitif etkisi olduğu sonucuna varmıștır.

Bu çalıșmalar incelenirken özellikle 2009 ve sonrası yayınlanan çalıșmalar üzerinde durulmuștur. 2009 öncesinde de bu alanda yapılmış çalıșmalar mevcuttur. Bunlar özelikle Gümrük Birliği (GB) ile ilgili çalıșmalardır. Bunun sebebi GB'nin Türkiye'nin en eski anlaşmalarından biri olmasıdır. Bunlara örnek olarak; Kızıltan vd. (2008) tarafından yayınlanan “Gümrük Birliği'nin Türkiye'nin Avrupa ile İhracat ve İthalatına Etkisi” adlı makalesini gösterebiliriz. Kızıltan vd. Türkiye'nin 1985-2005 yılları arsındaki dıș ticareti incelemiș ve GB'nin Türkiye'nin AB ülkeleri ile olan dıș ticaretini artırıcı bir etkiye sahip olduğu sonucuna varmıșlardır.

Türkiye'de yapılan çalıșmaların dıșında, yurtdıșında yapılmış çalıșmalar bulunmaktadır. Örneğin; Lohrman (2000) Grubel-Lloyd endeksini kullanarak 1989-1997 yılları için AB ile Türkiye arasındaki sanayi malları ticaretinde endüstri-içi ticaretin boyutlarını hesaplamıștır. Çalıșmada AB ve Türkiye arasındaki ticarette, toplam imalat sanayi için endeks değerinin arttığı ve GB'den sonra AB ile ticaretin sermaye mallarına ve beceri yoğun mallara doğru değișme eğiliminde olduğu sonucuna ulașılmıștır.

Ülkelerin dıș ticaretini geliștirmek ve potansiyel pazarları ortaya çıkarmak ya da ticari ilișkilerin nedenlerini incelemek gibi sebeplerle özellikle çekim modelinden yararlanarak yapılmış birçok çalıșma bulunmaktadır. Jakab (2001) çekim modelinden yararlanarak üç Orta ve Doğu Avrupa ülkelerinin fiili ve potansiyel ticaret düzeylerini analiz etmiștir. Antonucci ve Manzocchi (2004), Türkiye'nin Avrupa Birliği'ne girmesinin fark yaratıp yaratamayacağını çekim modeli ile açıklamaya çalıșmıștır. Fratianni (2007), üç grup ülke için analiz yapmıștır; gelișmiș ile gelișmiș, gelișmekte olan ile gelișmekte olan ve gelișmiș ile gelișmekte olan ülkeler arasındaki dıș ticaret akımlarını incelemiștir. 


\subsection{Lojistik ve lojistik üs (kümelenme) alanında yapılan çalıșmalar}

Uluslararası ticaret, anlașmalar ya da bölgeselleșme gibi konularda birçok araștırma ve inceleme yapılmıș olmasına rağmen lojistik alanında yapılan çalıșmaları incelediğimizde, akademik açıdan yapılan incelemelerin yeterli olduğu söylenemez. Bașka bir ifadeyle, diğer alanlar koșma așamasındayken lojistik hala emeklemektedir.

Bu alanda yapılan çalıșmalar ağırlıklı olarak sektör temsilcileri ve onların olușturduğu topluluklar (UTIKAD ve UND gibi) tarafından yapılmaktadır. Bunların dıșında Ticaret Odaları, IGEME ve TCDD gibi kurum ve kurulușlar da çalıșmalar yapmaktadır. Çalıșmalarında daha çok lojistik üslerin önemini vurgulamıș ve il bazında araștırmalar yapmışlardır. Örneğin İzmir Ticaret Odası'nın (IZTO) 2008 yılında hazırladığı Türkiye'nin Lojistik Potansiyeli ve İzmir'in Lojistik Faaliyetleri Açısından Durum Analizi raporu ve 2010 yılında hazırladığı Lojistik Merkez Kavramı ve İtalya'daki Lojistik Merkezler çalıșmaları bunlardan bazılarıdır.

Lojistik alanında yapılan diğer çalıșmalar incelendiğinde Türkiye'nin lojistik üs olması ile ilgili yazıların ağırlıklı olduğu söylenebilir. Örneğin Kara ve diğerlerinin (2009) yayınlamıș oldukları makalelerinde Küresel ticarette lojistik üslerin önemi ve Türkiye'nin lojistik üs olma performanslarını incelemișlerdir. Bu çalıșma Türkiye'nin lojistik üs olma performansını coğrafi avantajlarını kullanabilmesine ve kurumsal alt yapısını, teknoloji ile birleștirmesine bağlamıștır.

Akçetin (2010), “Avrupa Birliği’ne Üyelik Sürecinde Küresel Lojistik Üs Olma Yolunda Türkiye" makalesinde Türkiye'nin lojistik üs olma vasfını incelemiș ve bunun gerçekleștirilebilmesi için coğrafi avantaj, fiziksel ve kurumsal alt yapısının iyi olması gerektiği sonucuna vurgu yapmıștır.

Lojistik alanda yapılan bir diğer çalıșma da Kılıç vd. (2009) tarafından kaleme alınan “Gelișmekte Olan Ülkelerde Sürdürülebilir Kalkınma Açısından Lojistik Köyler: Türkiye Örneği” makalesidir. Bu makalede lojistik köylerin ekonomik ve toplumsal faydalarına, yurtdışında olduğu gibi ülkemizde de lojistik köy projelerinin uygulamaya konulduğunda, bulundukları bölgenin ticari potansiyeline ve ekonomik gelișimine önemli katkılar sağlayacağı sonucuna ulașılmıștır. Ayrıca çalıșmada, lojistik köylerin ișletmelerin rekabet gücünü arttıracağı ve kombine tașımacılığın gelișimine de katkıda bulunacağına vurgu yapılmıștır.

“Ulusal ve Uluslararası Tașıma ve Ticarette Lojistik Köylerin Yapılanma Esasları ve Uygun Kuruluș Yeri Seçimi” adlı makalesinde Elgün (2011) de lojistik merkezlerin sayısından çok, fonksiyonel olmalarının önemli olduğunu ve lojistik üs kurulacak yerlerinin seçim modelleri kullanarak test edilmesi gerekliliğinin önemine dikkat çekmiștir. 
Ayrıca lokasyonların (kurulum yerlerinin) özelliklerini ve lojistik potansiyellerini ortaya koymada kullanılabilecek teknik ve modeller önermiștir.

Lojistik tanımlamalar ve kurulum yeri seçimlerinden farklı olarak “Türkiye'de Lojistik Sektörünün Gelișmișlik Düzeyinin Seçilmiș AB Ülkeleri ile Karșılaștırmalı Bir Analizi” adlı makalelerinde Tutar vd. (2009) Romanya, Macaristan ve Türkiye'deki lojistik sektörünü incelemiș ve Türkiye'nin lojistik üs olma yetisine sahip olduğunu karșılaștırmalı veriler kullanarak dile getirmișlerdir.

Gültekin (2011) de lojistik kümelenmede yeni bir konuya dikkat çekmiș ve Türkiye'de tarımsal kümelenmenin gerekliliğine değinmiștir. Bu çalıșması ile kümelenmenin dıș ticarette rekabet gücü düzeyini nasıl artırdığını açıklamaya çalıșmıștır.

Çalıșmalarını lojistik üs (köy) kurulum yerlerinin belirlenmesi alanında gerçekleștiren Chen ve Qu (2006) entropi ağırlığına dayalı Bulanık ÇBKV, Wang ve Liu (2007) bulanık AHP ve TOPSIS, Ertuğrul ve Karakaşoğlu (2008) bulanık TOPSIS, Kayıkçı (2010) Bulanık AHP ve ANN, Turskis ve Zavadskas (2010) Bulanık Katkı Oranı Değerlendirmesi (ARAS-F) yöntemlerini kullanarak kurulum yerini belirlemeye yönelik çalıșmalar yapmışlardır.

Yukarıda belirtilen çalıșmalarda genellikle lojistik üs tanımları ve kurulumları ile ilgili araștırmalar yapılmıș ve Türkiye'nin lojistik üs olma potansiyeli üzerinde durulmuștur. Bu çalıșmaların dıșında Tsamboulas ve Kapros (2003) tarafından kamu ve özel sektör finansman belirsizliği altında lojistik köylerin değerlendirilmesine ilișkin bir model çaııșması yapmıștır.

Bu çalıșmada Türkiye'nin bölgedeki ticaret hacimlerine değinilecek ve Türkiye'nin yurtdıșında lojistik üs kurmasının ihracatını nasıl etkileyeceği incelenecektir.

\section{Dıș Ticaret}

Dünyada tüm kaynakların hepsine birden sahip olabilen bir ülke yoktur. Bu sebeple ülkeler ihtiyaçlarını karșılayabilmek için kendi üretemedikleri mal ve hizmetleri dış ticaret yoluyla elde etmek zorundadırlar. Örneğin Türkiye bazı tarım ürünlerinde yeterli miktarda üretim yapabilirken, enerji gibi yaşamın ve üretimin vazgeçilmez unsuru olan kaynakları bașka ülkelerden temin etmek zorundadır.

Türkiye'nin 2006-2012 yılları arasındaki ihracat ve ithalat rakamları incelendiğinde (Tablo.1) ihracat rakamları 85,5 milyar \$'dan 152,5 milyar \$'a kadar yükselmiștir. Bununla beraber ithalat rakamları 139,5 milyar \$'dan 236,5 milyar \$'a yükselmiștir (TÜiK, 2013: 1). 
Tablo 1:

Türkiye'nin Dıș Ticaret Hacmi (bin \$, 2006-2012)

\begin{tabular}{|c|c|c|}
\hline Yıllar & inracat (\$) & ithalat (\$) \\
\hline 2006 & 85.534 .676 & 139.576 .174 \\
\hline 2007 & 107.271 .750 & 170.062 .715 \\
\hline 2008 & 132.027 .196 & 201.963 .574 \\
\hline 2009 & 102.142 .613 & 140.928 .421 \\
\hline 2010 & 113.883 .219 & 185.544 .332 \\
\hline 2011 & 134.906 .869 & 240.841 .676 \\
\hline 2012 & 152.536 .653 & 236.544 .494 \\
\hline
\end{tabular}

Kaynak: TüiK, 2013

Türkiye'yi çevreleyen bölgeler incelediğinde özellikle Avrupa (AB üyesi olan ve olmayanlar), Ortadoğu ve Kuzey Afrika gibi bölgeler öne çıkmaktadır. Așağıda bu bölgelerden bazıları ile Türkiye'nin ticaret düzeyleri incelenmiștir.

\subsection{Ortadoğu ile Ticaret}

Geniș bir yeraltı zenginliğine sahip olan bölgenin ekonomik açıdan cazip koșulları, Türkiye-Ortadoğu ilișkilerini de temelden etkilemektedir. Diğer taraftan Türkiye, önemli ekonomik merkezlerin ve enerji kaynakları bakımından zengin bölgelerin bulunduğu Asya ve Avrupa'nın kesişme noktasında yer alması sebebiyle Ortadoğu ülkeleri için ayrı bir jeostratejik öneme sahiptir. Bu bağlamda, karşılıklı bağımlılık içerisinde bulunan Türkiye ve Ortadoğu arasındaki ticari ilișkiler, son yıllarda uygulanan “komșularla sıfır sorun politikası" ve "çok yönlü dıș politika" doğrultusunda yeni bir ivme kazanmıș ve Tablo 2' de görüleceği gibi Ortadoğu ülkeleri ile olan ticaret hacmi gözle görülür bir artıs sergilemiștir (İpekyolu Kalkınma Ajansı, 2011: 131).

Tablo 2:

Türkiye'nin Ortadoğu Bölgesindeki Ülkeler İle Ticareti (2008-2012; a: İthalat, b: İhracat, bin \$)

\begin{tabular}{|c|c|c|c|c|c|c|}
\hline & & $\mathbf{2 0 0 8}$ & $\mathbf{2 0 0 9}$ & $\mathbf{2 0 1 0}$ & $\mathbf{2 0 1 1}$ & $\mathbf{2 0 1 2}$ \\
\hline \multirow{3}{*}{ Lübnan } & $\mathrm{a}$ & 178.781 & 108.800 & 228.536 & 282.744 & 176.393 \\
\cline { 2 - 7 } & $\mathrm{b}$ & 665.055 & 688.681 & 618.318 & 718.257 & 846.230 \\
\hline \multirow{3}{*}{ Suriye } & $\mathrm{a}$ & 323.697 & 221.454 & 452.493 & 336.646 & 67.448 \\
\cline { 2 - 7 } & $\mathrm{b}$ & 1.115 .013 & 1.421 .637 & 1.844 .605 & 1.609 .861 & 500.976 \\
\hline \multirow{3}{*}{ Irak } & $\mathrm{a}$ & 133.056 & 120.558 & 153.476 & 86.753 & 149.328 \\
\cline { 2 - 7 } & $\mathrm{b}$ & 3.916 .685 & 5.123 .406 & 6.036 .362 & 8.310 .130 & 10.827 .668 \\
\hline
\end{tabular}




\begin{tabular}{|c|c|c|c|c|c|c|}
\hline \multirow{2}{*}{ İran } & a & 8.199 .689 & 3.405 .986 & 7.645 .008 & 12.461 .532 & 11.964 .613 \\
\hline & $b$ & 2.029 .760 & 2.024 .546 & 3.044 .177 & 3.589 .635 & 9.922 .580 \\
\hline \multirow{2}{*}{ İsrail } & a & 1.447 .919 & 1.074 .727 & 1.359 .639 & 2.057 .314 & 1.710 .401 \\
\hline & $b$ & 1.935 .235 & 1.522 .436 & 2.080 .148 & 2.391 .148 & 2.330 .263 \\
\hline \multirow{2}{*}{ Ürdün } & a & 25.289 & 20.354 & 42.450 & 66.480 & 95.996 \\
\hline & $b$ & 460.738 & 455.352 & 571.334 & 506.839 & 771.095 \\
\hline \multirow{2}{*}{$\begin{array}{l}\text { Suudi } \\
\text { Arabistan }\end{array}$} & a & 908.917 & 775.784 & 1.380 .601 & 2.001 .529 & 2.171 .061 \\
\hline & $b$ & 2.201 .875 & 1.768 .216 & 2.217 .646 & 2.763 .476 & 3.677 .732 \\
\hline \multirow{2}{*}{ Kuveyt } & a & 80.638 & 184.219 & 214.515 & 270.446 & 278.464 \\
\hline & $b$ & 493.035 & 211.242 & 395.051 & 297.207 & 290.633 \\
\hline \multirow{2}{*}{ Bahreyn } & a & 95.516 & 24.289 & 71.682 & 111.454 & 158.922 \\
\hline & $b$ & 308.223 & 113.628 & 172.024 & 160.418 & 208.809 \\
\hline \multirow{2}{*}{ Katar } & $\mathrm{a}$ & 159.353 & 85.652 & 177.046 & 481.018 & 466.499 \\
\hline & $b$ & 1.074 .013 & 289.361 & 162.549 & 188.138 & 257.489 \\
\hline \multirow{2}{*}{ B. A. E. } & a & 691.202 & 667.857 & 698.421 & 1.649 .456 & 3.596 .546 \\
\hline & $b$ & 7.975 .400 & 2.896 .572 & 3.332 .885 & 3.706 .654 & 8.175 .541 \\
\hline \multirow{2}{*}{ Umman } & a & 10.611 & 16.584 & 39.464 & 56.558 & 52.850 \\
\hline & $b$ & 215.755 & 105.518 & 129.311 & 214.651 & 268.562 \\
\hline \multirow{2}{*}{ Yemen } & $\mathrm{a}$ & 703 & 310 & 1.044 & 464 & 368 \\
\hline & $b$ & 353.605 & 379.263 & 330.392 & 272.733 & 485.975 \\
\hline
\end{tabular}

Kaynak: TÜIK, 2013

Türkiye, AB'ye olan bağımlılığını azaltmak için özellikle Ortadoğu 'ya yönelmiștir. Siyasi dönüșüm hareketleri nedeniyle sekteye uğramasına rağmen bazı ülkelerle ticareti yükselmeye devam etmiștir. Örneğin; Saddam Hüseyin'in devrilmesi ve Irak'ın işgal edilmesinden sonra Irak'la ticari ilișkiler artmış özellikle de yeniden yapılanma süreci ile birlikte Türk inșaat firmalarının akınına uğramıștır.

\subsection{Kuzey Afrika ile Ticaret}

Dünya topraklarının \%20,4'ünü olușturan Afrika, 30.221 .532 km² yüzölçümü ile Asya'dan sonra dünyanın ikinci büyük kıtasıdır (Geocat, 2013). Amerikan Uluslararası Kalkınma Ajansı (USAID), Afrika nüfusunun 1 milyarı geçtiğini ve yıllık nüfus artıșının 24 milyon kiși olduğunu söylemektedir. Ortalama ömrün kısa, doğum ve ölüm oranının yüksek olduğu Afrika kıtasında nüfusun önemli kesimi gençlerden olușmaktadır (Milliyet Gazetesi, 2009).

Türkiye'nin Afrika ile ticaretinde en büyük paya, Kuzey Afrika bölgesi sahiptir. Kuzey Af- 
rika bölgesi denilen yer Afrika'nın kuzeyinde yer alan ülkeler için kullanılan bir kavramdır. Bu bölgenin içine Fas, Cezayir, Tunus, Libya ve Mısır girmektedir. Bazı kaynaklara göre Batı Sahra ve Sudan'da Kuzey Afrika ülkeleri içinde yer almaktadır.

Tablo 3:

Türkiye'nin Kuzey Afrika Bölgesindeki Ülkeler İle Ticareti (2008-2012; a: İthalat, b: İhracat, bin \$)

\begin{tabular}{|c|c|c|c|c|c|c|}
\hline & & $\mathbf{2 0 0 8}$ & $\mathbf{2 0 0 9}$ & $\mathbf{2 0 1 0}$ & $\mathbf{2 0 1 1}$ & $\mathbf{2 0 1 2}$ \\
\hline \multirow{3}{*}{ Fas } & $\mathrm{a}$ & 360.520 & 234.729 & 396.798 & 419.945 & 429.482 \\
\cline { 2 - 7 } & $\mathrm{b}$ & 957.769 & 598.541 & 623.957 & 920.896 & 1.015 .150 \\
\hline \multirow{3}{*}{ Cezayir } & $\mathrm{a}$ & 1.587 .510 & 768.995 & 1.068 .38 & 1.150 .330 & 925.205 \\
\cline { 2 - 7 } & $\mathrm{b}$ & 1.613 .640 & 1.777 .200 & 1.504 .59 & 1.470 .550 & 1.813 .280 \\
\hline \multirow{3}{*}{ Tunus } & $\mathrm{a}$ & 365.381 & 234.980 & 280.720 & 249.790 & 195.624 \\
\cline { 2 - 7 } & $\mathrm{b}$ & 778.098 & 645.767 & 713.632 & 802.302 & 796.828 \\
\hline \multirow{3}{*}{ Libya } & $\mathrm{a}$ & 336.325 & 357.417 & 425.652 & 139.763 & 416.158 \\
\cline { 2 - 7 } & $\mathrm{b}$ & 1.074 .290 & 1.795 .120 & 1.932 .37 & 747.629 & 2.140 .070 \\
\hline \multirow{3}{*}{ Mısır } & $\mathrm{a}$ & 886.237 & 641.552 & 926.476 & 1.382 .220 & 1.342 .050 \\
\cline { 2 - 7 } & $\mathrm{b}$ & 1.426 .45 & 2.599 .030 & 2.250 .580 & 2.759 .310 & 3.679 .690 \\
\hline
\end{tabular}

Kaynak: TÜIKK, 2013

Tablo 3'de Kuzey Afrika'daki ülkeler detaylı incelendiğinde özellikle 2010 yılında Tunus, Fas ve Libya ile ihracatta artış yaşanmıșken Mısır ve Cezayir ile ihracatta azalma görülmektedir. Bölge ile ithalat düzeyleri incelendiğinde ise 2008-2010 yılları arasında Türkiye ile ithalatta devamlı olarak bir artış göstermektedir. 2011 yılının sonlarında siyasi dönüșüm hareketleri nedeniyle ticarette genel itibariyle bir düșüș yașansa da 2012 yılında yeniden artıș yașanmıștır.

Türkiye'yi çevreleyen ülke ve ülke gruplarını incelediğimizde Türkiye'nin özellikle Avrupa ülkeleri ile yoğun ticareti olduğu görülmektedir. Bu bölgedeki değișimler Türkiye'yi doğrudan etkilemektedir. Türkiye bölgesel bağımlılığını ortadan kaldırmak ve yeni pazarlar keșfetmek için diğer bölgelere yönelmelidir. Bu kapsamda Ekonomi Bakanlığı'nın görüșü ile 2012-2013 döneminde hedef ülkeler belirlenmiștir. Bu ülkeler ağırlıklı olarak Ortadoğu ve Afrika'daki ülkelerden olușmaktadır. Bu kararın alınmasında bu bölgede potansiyelinin altında ihracat yapılmasının etkili olduğu da görülmektedir. Örneğin Almanya, Fransa ve İngiltere gibi ülkeler ile ihracat rakamları 6 milyon dolara ulașmıșken Ortadoğu ve Kuzey Afrika ülkelerinden en yoğun ticaretin yapıldığı Mısır'a ihracat 2 milyon dolar seviyelerinde kalmıștır. Özellikle de bu bölgeyle olan ticaretin artırılması için bakanlık düzeyinde çalıșmaların yürütüldüğü ve kararların alındığı așikârdır. Bu sebeple Afrika'ya açılmak isteyen Türkiye için hem ulaşım kolaylığı, hem ülke istikrarlılığı hem de dıș ticaret verileri dikkate alınıldığında en uygun bölge Kuzey Afrika özelinde de 
Mısır'dır. Bu bölgeye kurulacak lojistik üs yardımıyla ticaret hacmi arttırılabilir.

\section{Lojistik Üs}

Dünyada lojistik hareketlerin artmasına paralel olarak, lojistiğin çalıșma yapısı ve iș süreçlerinde bir takım farklılıklar olmuș ve buna paralel olarak bir takım yeni ihtiyaçlar ve faaliyetler ortaya çıkmıștır. Ortaya çıkan tüm bu lojistik faaliyetler ve farklılıklar lojistik köylerin doğmasını gerekli kılmıștır. “Lojistik merkezler”, “lojistik üs” ve “lojistik köy” tanımlamalarıyla da ele alınmaktadır (Elgün, 2011: 205).

Lojistik üs, tașımacılık, dağıtım, depolama, elleçleme, konsolidasyon, ayrıștırma, gümrükleme, ihracat, ithalat ve transit ișlemler, altyapı hizmetleri, sigorta ve bankacılık, danıșmanlık ve üretim gibi birçok entegre lojistik faaliyetin belirli bir bölgede gerçekleștirilmesini ifade etmektedir (Erdal, 2012: 14)

\subsection{Lojistik üslerin faydaları}

Lojistik üs kurulumuyla birlikte, ișletmelere ve ülkelere sayısız faydalar sağlamaktadır. Bunlardan bazıları; ürün trafik akıșının optimize edilmesi, konteynır yükleme boșaltma faaliyetlerinin iyileștirilmesi, lojistik merkezden faydalanan firmaların tüketicilerinin ihtiyaçlarına daha hızlı cevap verilmesine imkan sağlar, kullanıcıların ișletme maliyetlerinin düşürülmesi, șirketlerin kendi dağıtım kanalları üzerindeki kontrolü artırmak için bir platform yaratması, șirketlerin kapasitelerini genișletmelerine olanak sağlaması ve hava, kara, demir, deniz ulaşım merkezlerine bağlantı için olanak sağlama gibi faydaları bulunmaktadır (IZTO, 2008: 2). Ayrıca lojistik üsler bölgenin planlı arazi kullanımını ve ekonomik gelișimini teșvik etmekte, trafik yükü ve çevre kirliliğini azalmaktadır (Sirikijpanichkul ve Ferreira, 2006: 11-20).

Bu faydaların dıșında lojistik üsler ülkelerin ticaret hacimlerini de artırmaktadır böylelikle firmalar yeni pazarlara ulaşabilir ve üretimi için gerekli olan hammadde ve yarı mamulleri daha uygun maliyetlerle temin edebilirler.

\subsection{Dünyada ve Türkiye'deki lojistik üsler}

Avrupa'da 1960'lı yılların sonlarından itibaren, “yük köyü” kavramı ortaya çıkmıștır. Verona'daki (İtalya) “Freight Village Quadrante Europa” yük köyünün, yaklașık 30 yıldır hizmet verdiği göz önüne alınırsa, yük köyü (lojistik köy) kavramının yıllar önce ortaya çıktığı söylenebilir. Ticaret akıșlarını rasyonelleștiren, bütünleșmiș hizmet sağlayan, ulaștırma türlerinin birleșimini sağlayan, katma değerli lojistik hizmetler veren, kesintisiz șehir dağıtımını sağlayan ve șehir tıkanıklığını önlemeye çalışan lojistik hareketlerin toplandığı yer olan lojistik köyler, önemi gün geçtikçe artan merkezler olarak değerlen- 
dirilmektedir. Önce ABD ardından Japonya ve Batı Avrupa'ya geçmiş olan uygulamanın ilk örnekleri Fransa'da geniş ölçekte Paris bölgesel alanında Garanor ve Sogoris (Rungis) çevresinde olușturulmuștur. Bu uygulama, kentsel politikalara bağlı olarak geliștirilmiștir. 1960'ların sonları ve 70'lerin bașında ise lojistik köyler, İtalya ve Almanya'da kurulmaya bașlamıștır. Bu sırada lojistik köy kavramı da șekillenmeye bașlamıș ve karayolu/demiryolu çok türlü tașımacılığını sağlar hale getirilmiștir. 1980 ve 90'lı yıllarda ise lojistik köyler, dünyada hızla artma eğilimi göstererek Fransa, Almanya, İtalya, Hollanda, Belçika ve Ingiltere'de ilerlemeler kaydetmiș ve günümüzde lojistik köylerin avantajlarının farkına varılarak tüm dünyada örnekleri çoğalmaya bașlamıștır (Aydın ve Öğüt, 2008: 48). Örneğin Hong Kong, Antwerp, Rotterdam, Hamburg, Singapur, Dubai, Tokyo, Los Angeles, New York, Paris liman ve hava alanları en önemli lojistik merkezler arasında yer almaktadırlar (Stopford, 2009: 345-383).

Türkiye'de ise lojistik üs kavramı yeni bir olușum olarak karșımıza çıkmaktadır. Bu alandaki çalıșmalar ağırlıklı olarak devlet destekleriyle yapılmaya çalıșılmaktadır. Son yıllarda lojistiğin gelișmesiyle Türkiye lojistik üslerin önemini anlamıș ve çalıșmalarını hızlandırmıștır. Türkiye'de kurulması planlanan lojistik üslerin bașında İstanbul/ Halkalı, İzmit/Köseköy, Balıkesir/Gökköy, Samsun/Gelemen, Mersin/Yenice, Kayseri/ Boğazköprü ve Erzurum/Palandöken lojistik üsleri gelmektedir. Bunların dıșında özel sektörlere ait birçok lojistik üs projeleri bulunmaktadır. Bunlara örnek olarak İstanbul Hadımköy ve Tuzla Lojistik Köy Projesi, Tekirdağ/Çorlu Lojistik Köyü ve Manisa Lojistik Köyü projelerini sıralayabiliriz.

Ülkeler sadece kendi bünyelerinde değil diğer ülkelerde de lojistik üsler kurarak ülke ekonomilerini geliștirmek ve maliyetleri düșürmek gibi nedenlerle lojistik üsler açabilmektedirler. Bunlara Türkiye'nin Suriye ve Amerika Birleșik Devletleri'nde kurduğu lojistik üsleri örnek gösterebileceğimiz gibi görüșmelerin hala devam ettiği Rusya'ya lojistik üs kurulumu projesini de örnek gösterebiliriz.

\subsection{Mısır'a lojistik üs kurmanın önemi}

Mısır 1.001,450 km2'lik yüz ölçümü ile dünyanın en geniș 30. ülkesidir. Kuzeydoğu Afrika'da yer alan, kuzeyden Akdeniz ve doğudan Kızıldeniz'le kuşatılmıș ve Sina Yarımadası ile Asya kıtasına da taşan bir ülkedir.

Mısır'da modernleșen vergi sistemi, getirilen kolaylıklar ve mevzuatların basitleștirilmesi yabancı yatırımlar açısından ülkeyi cazip kılmıș ve yatırımcıları çekmiștir (Birleșmiș Markalar Derneği, 2012:1-97).

"Yatırım ortamı, 1997 yılında yürürlüğe giren Yatırım Teșvikleri Kanunu ve 1998 yılında yürürlüğe giren Șirketler Kanunu tarafından düzenlenmektedir. Bu kanunlar 
çerçevesinde yatırım yapan yatırımcılara \%100 mülkiyet hakkı tanınmıștır. Aynı kanun Mısır'daki tüm yatırımları millileștirme ve kamulaștırmaya karșı garanti altına almıștır. Bütün bu etkenler nedeniyle de 2010 yılı itibariyle ülkeye 6,8 milyar dolar doğrudan yabancı yatırım giriși gerçekleșmiștir"(DEIK,2011:5).

Süveyș kanalını kontrol eden Mısır, bu bölgede deniz, kara ve hava bağlantıları ile çok önemli bir tașımacılık ve ticaret merkezi haline gelmiștir. Son yıllarda Suriye'de yașanan gelișmeler nedeniyle bölgeyle olan ticari ilișkileri durmuș hatta Suriye hattı üzerinden ticaret yapılamaz hale gelmiștir. Bu sebeple Türkiye 24 Nisan 2012' de, Mısırla ilgili karayolu anlașmasını da kapsayan bir Ro-Ro hattının faaliyete geçmesi ile ilgili bir protokol imzalamıștır. Böylelikle Ortadoğu ve Kuzey Afrika'ya ulașım sorunları ortadan kaldırılmıș ve Suriye güzergâhı kullanımdan kaldırılmıș ve alternatif bir rota geliștirilmiștir. (Anadolu Ajansı, 2012 ve Erdoğan, 2012)

Mısır, Afrika ve Ortadoğu ile tașıma ağlarının bulunması, Mısır yönetiminin sağlamıș olduğu yatırım kolaylıkları, baskın bir tașıma türünün varlığı ve diğer tașıma türleri ile birleștirilebilme imkânı bulunması gibi nedenlerle Mısır'da kurulacak bölgesel bir lojistik üs, Türkiye için oldukça cazip bir proje olmaktadır.

Mısırda kurulacak bir lojistik üssün büyüklüğü en az 100,000 $\mathrm{m}^{2}$ alana sahip olmalıdır. Türkiye'de kurulması planlanan lojistik üslerin bile asgari alanı 120,000 $\mathrm{m}^{2}$ 'dir. Konumu ise bir șehrin içinde ya da yakınında olmakla beraber yerleșim bölgelerinden uzakta olmalıdır. Kara ve demir yolu gibi ana ulașım bağlantılarına sahip olmalıdır. Limanlara, iç suyollarına ve hava alanlarına yakın ya da kolay erișim olanağı olmalıdır. Mısır’ın seçilmesindeki amaçta, bu iç suyolu ve limanlardan yararlanılmaktır. Kurulacak üssün içerisinde gümrük müșavirlikleri ve acenteler için modern ofisler, silolar, tır parkı alanları, restoran ve dinlenme tesisleri, antrepolar, akaryakıt istasyonları, özel stok alanları ve depolar bulundurulmalıdır. Gelișmiş iletișim ve bilgi teknolojisi altyapısı kurulması gerekmektedir. Maliyeti ile ilgili değerlendirme yapabilmek için detaylı bir fizibilite çalıșması yapılmalı ve lokasyonun net belirlenmesi gerekmektedir. Mısır hükümetinin bu konudaki tutum ve sağladığı teșvikler doğrultusunda yer belirlendikten sonra maliyet hesaplanabilir. Türkiye'de kurulacak 511.000 m²'lik Kayseri Boğaz Köprü lojistik üssünün maliyetinin 90 milyon avro olduğu düșünülürse Mısır'a kurulacak bir lojistik üs, maliyetlerini çıkartacak potansiyele sahiptir.

Kurulacak lojistik üs ile Kuzey Afrika bölgesi ağırlıklı olmak üzere Afrika kıtasının tamamına ulașım sağlanabilecektir. Afrika genelinde büyük pazar payına sahip olan ülkelerin hâkimiyeti biraz azaltılabilir ve Türkiye'nin de pazarda kendine yer bulabilmesi sağlanabilir. 


\section{Sonuç}

Her geçen gün dünyada ticarete konu olan ürünler ve ürünlere verilen değer değișmiștir. Bununla birlikte artık bir malın üretilmesinden çok, müșterisinin bulunması ve ona uygun koșullarda teslim edilmesi önem kazanmıștır. Ticari ilișkilerin kurulabilmesi ve ticaretin yapılabilmesi artık sadece sınır kapılarında ve birkaç limanda yapılamayacağından dolayı dünya yük tașımacılığından lojistik kavramına geçmiștir. Türkiye ise lojistiğin önemini geç anlamıș ama son yıllarda lojistik master planlarını olușturmaya ve bunları eyleme geçirmeye bașlamıștır.

Günümüz dünyasında enerji olmadan insanın hayatını bile devam ettirebilmesi mümkün değildir. Bu yüzden enerji konusunda zengin ve el değmemiş yeraltı kaynaklarının bulunduğu Afrika ülkeleri gelișmiș ülkelerle birlikte, Türkiye'nin de dikkatini çekmiștir. Afrika ülkelerinde yoğun bir tüketim açlığı bulunmaktadır. Ancak bunların fiyatını ödeyebilecek mali imkânlara sahip ülke sayısı azdır. Bu sebeple ödemelerini ucuz enerji ve değerli yeraltı madenleri ile yapmaktadırlar. Türkiye de dıș ticaret yaptığı ülkelerde döviz yerine hammadde ve enerji ürünleri alarak enerji ve hammadde ihtiyacını daha uygun maliyetlerle sağlayabilir.

Türkiye'nin lojistik üs yapımında dikkat edeceği en önemli nokta; yer seçimi ve Türkiye'ye sağlayacağı avantajlardır. Bunları dikkate alarak yapılan çalıșmalar sonucunda Afrika'daki lojistik üssün; nüfus, Nil Nehri'nin ulașımda kullanılması ve Süveyș kanalının dünya ticaretindeki önemi sebebiyle Mısır en uygun yer olmaktadır. Bunun dıșında Mısır'ın lojistik üs olarak seçilmesinin bir diğer nedeni de Afrika'ya açılan bir köprü olmasıdır. Yine Mısır'da elektrik gibi önemli maliyet kalemleri Türkiye ile kıyaslandığında çok daha düșük fiyatlara sahiptir. Ayrıca bu bölgeye yatırımcıları çekmek için büyük teșvikler ve kolaylıklar sağlanmaktadır.

İleride yapılacak çalıșmalarda Türkiye'nin yurtdıșında açmıș olduğu lojistik üsler incelenerek ihracatın artırılması/arttırılması için hangi bölge ve șehirlere lojistik üs kurulması gerektiği ile ilgili araștırmalar yapılabilir ya da kurulmuş olan lojistik üslerin ihracata etkileri incelenebilir.

\section{KAYNAKÇA}

Akçetin, Eyüp (2010) “Avrupa Birliği’ne Üyelik Sürecinde Küresel Lojistik Üs Olma Yolunda Türkiye”, Adıyaman Üniversitesi Sosyal Bilimler Enstitüsü Dergisi, 3(5), s.1-14.

Anadolu Ajansı (tarihsiz) “Ro Ro Hattı Seferleri Yarın Bașlıyor” http://www.aa.com.tr/tr/ haber/47419--ro-ro-hatti-seferleri-yarin-basliyor, Erișim tarihi: 25 Nisan 2012. 
Antonucci, Daniele ve Stefano Manzocchi (2004) "Could Accession to the EU Make a Difference? An Empirical Assessment of Turkey's Trade Patterns", CNR-National Research Council Group on International Economics and Development çalıștayında sunulmuș tebliğ, Bocconi Üniversitesi, İtalya.

Aydın, Gülșen Teslime ve Kemal Selçuk Öğüt (2009) “Avrupa ve Türkiye’de Lojistik Köyleri", web.itu.edu.tr/oguts/Avrupada\%20ve\%20T\%FCrkiyede\%20lojistik\%20 k\%Fbyler.PDF, Erișim tarihi: 12 Kasım 2009.

Birleșmiş Markalar Derneği (2012) “Hedef Ülke Raporu: Mısır”, birlesmismarkalar. org.tr/images/UF/file/hedef-ulke-raporlari/M\%C4\%B1s\%C4\%B1r.pdf, Erișim tarihi: 17 Nisan 2012.

Chen, Yan ve Lili Qu. (2006) “Evaluating the Selection of Logistics Centre Location Using Fuzzy MCDM Model Based on Entropy Weight", 6. Dünya Akıllı Kontrol ve Otomasyon Kongresi'nde sunulmuș tebliğ, Dalian, Çin.

DEIK (2011) Mısır Ülke Raporu, Ankara.

DTM (2010) Dıș Ticaretin Görünümü 2023 Stratejileri, Ankara.

Elgün, Mahmut Nevfel (2011) “Ulusal ve Uluslararası Tașıma ve Ticarette Lojistik Köylerin Yapılanma Esasları ve Uygun Kuruluș Yeri Seçimi”, Afyon Kocatepe Üniversitesi IIBF Dergisi, XIII(II), s.203-205.

Erdal, Murat (2012) “Lojistik Üs Kavramı ve Türkiye Analizi”, www.utikad.org.tr/pdf/ Lojistikuskavrami.pdf, Erișim tarihi: 20 Nisan 2012.

Erdoğan, Murat (2012) “Nakliyeci Afrika Pazarına Mısır'dan Girecek”, www. persemberotasi.com/2012/04/nakliyeci-afrika-pazarina-misir\%E2\%80\%99dan-girecek, Erișim tarihi: 19 Nisan 2012.

Ertuğrul, İrfan ve Nilsen Karakașoğlu (2008) “Comparison Of Fuzzy AHP and Fuzzy TOPSIS Methods for Facility Location Selection”, The International Journal Of Advanced Manufacturing Technology, 39(7-8), s.783-795.

Fratianni, Michele (2007) The Gravity Equation In International Trade, Handbook of International Business, 2nd Edition, Ingiltere: Oxford University.

Genç, Murat Can, Seyfettin Artan ve Metin Berber (2011) “Karadeniz Ekonomik İ Birliği Bölgesinde Ticaret Akımlarının Belirleyicileri”, Atatürk Üniversitesi Iktisadi ve Idari Bilimler Dergisi, 25(2), s.207-224. 
Geocat (tarihsiz) “Afrika”, www.geocat.com.tr/kitalar.php?act=KITA\&ref=3, Erișim tarihi: 5 Haziran 2013.

Gültekin, Sadettin (2011) “Küreselleșme Çağında Dıș Ticarette Rekabet için Kümelenme Stratejisi: Türkiye'nin Tarım Kümelenmesi Gerekliliği", Kocaeli Üniversitesi Sosyal Bilimler Dergisi, 22(2), s.29-40.

İpekyolu Kalkınma Ajansı (2011) Ortadoğu Raporu, Gaziantep.

izTO (2008) Türkiye'nin Lojistik Potansiyeli ve Izmir'in Lojistik Faaliyetleri Açısından Durum Analizi Raporu, İzmir.

izTo (2010) Lojistik Merkez Kavramı ve Italya'daki Lojistik Merkezler, İzmir.

Jakab, Zoltán M., Mihaly A. Kovacs ve Andras Oszlay (2001) “How Far Has Trade Integration Advanced?: An Analysis Of The Actual And Potential Trade of Three Central and Eastern European Countries", Journal of Comparative Economics, 29(2), s.276-292.

Kara, Mehmet, Lütfü Tayfur ve Hamit Basık (2009) “Küresel Ticarette Lojistik Üslerin Önemi ve Türkiye”, Mustafa Kemal Üniversitesi Sosyal Bilimler Enstitüsü Dergisi, 6(1), s.69-84.

Karagöz, Kadir ve Murat Karagöz (2009) “Türkiye'nin Küresel Ticaret Potansiyeli: Cekim Modeli Yaklașımı", C.Ü. Iktisadi ve Idari Bilimler Dergisi, 10(2), s.127-144.

Kayıkçı, Yașanur (2010) “A Conceptual Model for Intermodal Freight Logistics Centre Location Decisions", Procedia-Social and Behavioral Sciences, 2(3), s.6297-6311.

Kılıç, Yavuz, M. Aycan Karaatlı, Fatih Demiral ve Yunus Pala, (2009) “Gelișmekte Olan Ülkelerde Sürdürülebilir Kalkınma Açısından Lojistik Köyler: Türkiye Örneği”. Uluslararası Davraz Kongresi'nde sunulmuș tebliğ, 24-27 Eylül 2009, Süleyman Demirel Üniversitesi, Isparta.

Kızıltan, Alaattin, Mustafa Ersungur ve Özgür Polat (2008) “Gümrük Birliğinin Türkiye'nin Avrupa Birliği ile İhracat ve İthalatına Etkisi”, Atatürk Üniversitesi Iktisadi ve Idari Bilimler Dergisi, 22(1), s.83-99.

Lohrmann, Astrid-Marina (2000) “Development Effects of the Customs Union between Turkey and the European Union: Catching-Up or the Heckscher-Ohlin Trap?", Russian and East European Finance and Trade, 36(4), s.26-44. 
Milliyet Gazetesi (2009) “Afrika'nın Nüfusu 1 Milyarı Geçti” dunya.milliyet.com.tr/ afrika-nin-nufusu---milyari-gecti/dunya/dunyadetay/23.08.2009/1131262/default.htm, Erișim tarihi: 15 Mart 2012.

Özkaya, Hakan (2011) “ikili ve Çok Taraflı Anlașmaların Türkiye'nin İhracatı Üzerindeki Etkisi”, Doğuș Üniversitesi Dergisi, 12(2), s.279-288.

Sirikijpanichkul, Ackchai ve Luis Ferreira (2006) "Solving the Conflicts in Intermodal Freight HubLocation Decisions", 5. BEE Postgraduate Infrastructure Theme Conference'da sunulmuș tebliğ, Queensland University of Technology, Avustralya.

Stopford, Martin (2009) Maritime Economics, Third Edition, New York: Taylor ve Francis Group.

Tsamboulas, A. Dimitrios ve Seraphim Kapros (2003) “Freight Village Evaluation Under Uncertainty with Public and Private Financing", Transport Policy, 10(2), s.141-156.

Turskis, Zenonas ve Edmundas Kazimieras Zavadskas (2010) “A New Fuzzy Additive Ratio Assessment Method (ARAS-F) Case Study: The Analysis Of Fuzzy Multiple Criteria in order to Select the Logistic Centers Location", Transport, 25(4), s.423-432.

Tutar, Erdinç, Filiz Tutar ve Handan Yetișen (2009) “Türkiye'de Lojistik Sektörünün Gelișmișlik Düzeyinin Seçilmiș AB Ülkeleri (Romanya ve Macaristan) IIle Karșılaștırmalı Bir Analizi", KMU IIBF Dergisi, 11(17), s.190-216.

TÜIK (2013) “Ülkelere Göre Dıș Ticaret Verileri”, http://www.tuik.gov.tr/VeriBilgi. do?altid=12, Erișim tarihi: 28 Şubat 2013.

Wang, Shengyuan ve Peide Liu (2007) “The Evaluation Study on Location Selection of Logistics Center Based on Fuzzy AHP and TOPSIS", Uluslararası Kablosuz Iletișim, Ağ Olușturma ve Mobil Bilgisayar Kullanım Kongresi'nde sunulmuș tebliğ, Sanghay, Çin. 


\title{
SELECTION OF CONTAINER PORT WITH FAHP-TOPSIS TECHNIQUE
}

\author{
İPEK EKER (1), AYFER ERGİN (2), GÜLER ALKAN (3)
}

\begin{abstract}
In today's world, more than $80 \%$ of world trade is done by sea transportation. Especially in 2000's, container transportation, formerly named as unitized cargo, and has reached very high numbers. The reason for the rapid increase in container transportation, in recent years, is that it can easily be integrated to other transportation systems. With globalization the increase in sea transportation, has brought the increase with the container transportation. Hence, in order to make the transportation network more efficient the importance of the selection of container ports has been increased. The research presented in this paper applies an integrated model using both the Fuzzy Analytic Hierarchy Process (FAHP) and TOPSIS methods to reveal and analyze container port selection by global container carriers. By the FAHP model, we can obtain the importance weight of each factor influencing the decision-making of carriers' port choices. By TOPSIS technique, container ports are ranked.
\end{abstract}

Within the process of defining the criteria expert opinions in shipping line firms were taken as well as the research was made in literature among the international articles published. In application of this study, Ambarlı Port region is chosen since this area has more than 42.04 (according to maritime trade statistics 2012) percent handling ratio of container transportation in Turkey. Thus, the criteria which are important on behalf of port selection such as geographic location, the hinterland economy, and customs were eliminated. Due to the reason that the study was made in a particular region elimination of the above-mentioned criteria is intended to bring a difference within the studies had been published in the literature. In addition, the criteria like port performance, port infrastructure, cost, information systems used in ports, and port security is selected in order to emphasize the difference in this study. Finally, the most important criterion is

1 Lecturer, BeykozVocational School of Logistics, ipekekerabeykoz.edu.tr

2 Research Assistant, Dr., İstanbul University, Department of Maritime Transportation Management Engineering, ayfersandistanbul.edu.tr

3 Professor Dr., İstanbul University, Department of Maritime Transportation Management Engineering. 
determined as "cost" while the second important criterion is "port efficiency". Among the present alternative container ports, alternative port $A$ is selected as the one which has the highest score.

Keywords: Fuzzy AHP, Port selection, TOPSIS Method

JEL Codes: C01, C02, C44, C61, R10, R40

Öz

Günümüzde dünya ticaretinin \%90'dan fazlası denizyolu tașımacılığı ile yapılmaktadır. Birimleștirilmiş yük olarak adlandırılan konteynır tașımacılığı özellikle 2000'li yıllarda çok yüksek sayılara ulașmıștır. Son yıllarda konteynır tașımacılığındaki hızlı artışının sebeplerinden birisi de diğer taşıma sistemlerine kolaylıkla entegre olabilmesidir. Globalleșmeyle birlikte deniz tașımacılığındaki artıș, beraberinde konteynır tașımacılığında da artış getirmiștir. Bu bağlamda tașımacılık ağını daha verimli hale getirmek konteynır limanlarının seçiminin önemini artırmıștır. Bu çalıșmada konteynır taşıyıcıları tarafından konteynır liman seçimini analiz etmek için yapılan uygulamada bulanık analitik hiyerarși süreci ve TOPSIS yöntemleri birlikte kullanılmıștır. Belirlenen kriterlerin ağırlıklarının hesaplanmasında bulanık AHP yöntemi ve bu ağırlıklar kullanılarak, TOPSís yöntemi ile alternatiflerin sıralanması gerçekleștirilmiștir.

Kriterleri belirlerken öncelikle literatürde bulunan uluslararası makaleler incelenmiș ve konteynır limanı seçmek adına konteynır taşıyıcı firmalarındaki uzman kișilerin görüșleri alınmıștır. Uygulama olarak Türkiye konteynır taşımacılığının \%40'tan fazlasını elleçleyen Ambarlı liman bölgesi seçilmiștir. Böylelikle liman seçimi adına önem tașıyan coğrafi lokasyon ve hinterland ekonomisi ve gümrük gibi kriterler elenerek özellikle liman performansı, altyapısı, fiyat, limanlarda kullanılan bilgi sistemleri ve liman güvenliği gibi kriterleri vurgulaması adına çalıșmanın farklılık getirmesi amaçlanmıștır. Sonuçta, en önemli kriter "fiyat" olurken ikinci en yüksek değeri alan kriter "liman verimliliği" olarak belirlenmiștir. Alternatif konteynır limanları arasında yapılan uygulama sonucunda en yüksek değeri alan A alternatif liman olarak seçilmiștir.

Anahtar Kelimeler: Bulanık AHP, Liman seçimi, TOPSIS Yöntemi

JEL Kodları: C01, C02, C44, C61, R10, R40 


\section{Introduction}

At the present time, $90 \%$ of world trade is being handled through seaports. This amount of handling ratio reflects the importance of ports in national and especially in international transportation. Container transportation referred as unitized cargo has increased since it can easily be integrated to other transportation modes, gets reduction in cargo handling time and costs, decreases the loss and damages, and presents safe and secure environment for the cargo. As a result, around 17 per cent of word seaborne trade relates specifically to container trade. The potential for container trade to continue increasing its share of dry cargo sector is therefore a real possibility. World container port throughput increased by an estimated 5.9 per cent to 572.8 million TEUs in 2011, its highest level ever (UNCTAD, 2012: 79). Parallel to world container trade Turkey's container port throughput has raised up by 6.63 per cent to 7.192,396 TEU in 2012 (DTGM, 2013: 25).

Being an interface linking sea and inland transportation, a port is an integral platform, serving as a base for logistics, production, information transfer and international trade, and as a springboard for the economic development of the hinterland (Lam and Dai, 2012: 509). Sea port choice is one of important issues in the development of international trade of the countries. Hence selection of the appropriate container port is a complex problem since it has both qualitative and quantitative variables. And it is requires an extensive evaluation process. In order to reduce the total transportation cost, and to increase the service quality, they are very important for shipping carriers to choose an optimal port for callings.

A containership involves a major capital investment, the daily operating costs e.g. the fuel cost, the crew salary, and the depreciation cost. The daily operating costs of a large containership may amount to thousands of US dollars. To select an optimal container port for containership calling could yield great potential of improving their economic performance and costs saving (Chou, 2010: 221). To choose an appropriate container port, a number of both quantitative and qualitative criteria should be considered and evaluated. Therefore port selection can be considered as a multiple criteria decision making (MCDM) problem. Since these criteria may vary in the degree of importance, analytic hierarchy process (AHP), one of the MCDM methods, is employed to identify these criteria, to define the effects of them on each other, to assess their importance and to choose a particular container port.

Recently, the port selection problem has received more attention and some studies have been reported in the literature. These studies are being mentioned in the literature review section of this study. In practice, the current mode of planning is still to a large extent undertaken manually, where considerable professional knowledge and experience 
is the key driver. This may not be an ideal method when time is of the essence and rapid decision-making is required to respond in competitive business conditions. A better, faster approach should be called for. There are numerous studies on freight transport choice by shippers, but they are mostly focused on modal choice and carrier selection, rather than addressing the more specific question of choice between competing ports. On the other hand, we think that the selection of port choice is an important issue in container transportation. Thus the results from this study can provide some practical information on port choice factors.

Most of the port selection methods mentioned have been developed based on the concepts of exact measurements and crisp evaluation. However most of the selection parameters cannot be given precisely and the evaluation data of the alternative ports suitability for various subjective criteria and the weights of the criteria are usually expressed in linguistic terms by the decision makers. This makes fuzzy logic a more natural approach for this kind of problems.

The remainder of this paper is organized as follows. The literature review is shown in Section 2. In Section 3 the methodology about Fuzzy AHP and TOPSIS are presented, and in Section 4 the proposed FAHP-TOPSIS methodology and the results of an application are given. Finally, some conclusions are presented in Section 5.

\section{Literature Review}

A wide number of studies have researched the factors determining the choice of ports. There are so many factors that are considered for selection of container ports. Brian (1985: 293) utilized the following 11 factors for port selection; port security, size of port, inland freight rates, port charges, quality of customs handling, free time, congestion, port equipment, number of sailings, proximity of port, possibility of inter-modal links. Tongzon and Sawant (2007: 477) developed a model for port choice of the shipping lines based on a revealed preference approach. The empirical study is based on a survey conducted among major shipping lines operating in Singapore and Malaysia. The findings have shown port charges and wide range of port services to be the only significant factors in their port choice. Chang et al. (2008: 877) applied a survey to shipping companies. As a result of this, six factors as; local cargo volume, terminal handling charge, berth availability, port location, transshipment volume and feeder network were considered relatively important. Tongzon (2009: 186) considered the criteria for port choice from freight forwarders' perspective. Finally, four criteria are found to be important. These are, efficiency, shipping frequency, adequate infrastructure and location, respectively.

One of the most important issues in today's international container transportation is the choice of transshipment port. In this sense, the choice of the transshipment port is the 
critical decision to make. For reduction on operational and port costs, while choosing the efficient, fast and good service giving port. There also have been many researches made on transshipment port choice. Lirn et al. (2003: 229) used the AHP technique to identify the importance of factors that influence transshipment port selection by Taiwanese ocean container carriers. Four main criteria and sixteen sub-criteria were applied in the study.

In their study regarding the work of an international transshipment port selection, Lirn et al. (2004: 70) have implemented an AHP technique using a survey of consisting 4 main and 12 sub-criteria for both global ocean container operators and port service providers and compared the results. Chou $(2007: 435,441)$ proposed a new fuzzy multiple criteria decision making method for solving the transshipment container port selection problem under fuzzy environment. Chou utilized six main criteria and eighteen sub-criteria.

Many research methods for port choice have been developed and proposed. Some of these methods are Mathematical Programming Models, Strength Weakness Opportunity and Threat (SWOT) analysis method, Multi Criteria Decision-Making (MCDM) Models, Hybrid Models, and Fuzzy MCDM Models. The commonly used method is AHP model which can integrate the qualitative factors and quantitative data. Ugboma et al. (2006: 251) utilized seven criteria for the port selection decision and identified four ports. The decision problem was structured into a three-level hierarchy using the Analytic Hierarchy Process. The findings suggest that shippers place high emphasis on efficiency, frequency of ship visits and adequate infrastructure, on the other hand quick response to port users' needs was insignificant to them. Chou (2010: 221) proposed an Analytic Hierarchy Process (AHP) model for simulating the behaviors of carriers' port choice and identifying the importance weight of every influential factor influencing carriers' port choices in the multiple-ports region. Onut et al. (2011: 182-187) studied a real world problem of a production firm which has three main warehouses and seven production facilities in the Marmara Region. In this study, an evaluation among seven alternative container ports with six main criteria has been made for a production firm. Chou et al. (2010: 1080) formulated a combined fuzzy multiple criteria decision making and optimization programming model for solving the container transportation demand split problem. Shengrong and Huiyuan (2010: 488) build a combined model of Cluster and TOPSIS analysis according to the characteristics of these two methods, and they use the model to evaluate port competitiveness of ten coastal ports in China. Veldman et al. (2011: 509) used a multinomial logic model for establishing a demand choice function for the Spanish container port services. Tran (2011: 39) sets up a non-linear programming model to deal with port choice decisions. The model has been applied in real data, with cargo flows between the USA and Northern Europe. Lam and Dai (2012: 514) integrate AHP with DSS using AIMMS, an optimization system development tool, in 2012. 


\section{Methodology}

\section{a. Fuzzy analytic hierarchy process}

In application, Chang's method is used. Let $X=\{x 1, x 2, \ldots, x n\}$ be an object set, and $U$ $=\{u 1, u 2, \ldots, u n\}$ be a goal set. According to the method of Chang's (1992: 352) extent analysis, each object is taken and extent analysis for each goal, gi; is performed, respectively. Therefore, $m$ extent analysis values for each object can be obtained, with the following signs:

$M_{g i}{ }^{1}, M_{g i}^{2}, \ldots \ldots \ldots M_{g i}^{m}, \quad \mathrm{i}=1,2, \ldots \mathrm{n}$

Where all the $M_{g i}^{j}(\mathrm{j}=1,2, \ldots \mathrm{m})$ are TFNs. The steps of Chang's extent analysis can be given as in the following:

Step 1: The value of fuzzy synthetic extent with respect to the ith object is defined as:

$S_{i}=\sum_{j=1}^{m} M_{g_{i}}^{j} \otimes\left[\sum_{i=1}^{n} \sum_{j=1}^{m} M_{g_{i}}^{j}\right]^{-1}$

To obtain $\sum_{j=1}^{m} M_{g_{i}}^{j}$ perform the fuzzy addition operation of $\mathrm{m}$ extent analysis values for a particular matrix such that:

$\sum_{j=1}^{m} M_{g_{i}}^{j}=\left(\sum_{j=1}^{m} l_{j}, \sum_{j=1}^{m} m_{j}, \sum_{j=1}^{m} u_{j}\right)$

And to obtain $\left[\sum_{i=1}^{n} \sum_{j=1}^{m} M_{G_{i}}^{j}\right]^{-1}$ perform the fuzzy addition operation of, $M_{g i}^{j}(\mathrm{j}=1,2, \ldots, \mathrm{m})$ values such that:

$\sum_{i=1}^{n} \sum_{j=1}^{m} M_{g_{i}}^{j}=\left(\sum_{i=1}^{n} l_{j}, \sum_{i=1}^{n} m_{j}, \sum_{i=1}^{n} u_{j}\right)$

And then compute the inverse of the vector such that:

$$
\left[\sum_{i=1}^{n} \sum_{j=1}^{m} M_{g_{i}}^{j}\right]^{-1}=\left(\frac{1}{\sum_{i=1}^{n} u_{i}}, \frac{1}{\sum_{i=1}^{n} m_{i}}, \frac{1}{\sum_{i=1}^{n} l_{i}}\right)
$$

Step 2: The degree of possibility of $M_{2}=\left(l_{2}, m_{2}, u_{2}\right) \geq M_{1}=\left(l_{1}, m_{1}, u_{1}\right)$ is defined as:

$$
V\left(M_{2} \geq M_{1}\right)=\sup _{y \geq x}\left\lfloor\min \mu_{M_{1}}(x), \mu_{M_{2}}(y)\right\rfloor
$$


And can be equivalently expressed as follows:

$$
V\left(M_{2} \geq M_{1}\right) \operatorname{hgt}\left(M_{1} \cap M_{2}\right)=\mu_{M_{2}}(d) \begin{cases}1, & \text { if } m_{2} \geq m_{1} \\ 0, & \text { if } l_{1} \geq u_{2} \\ \frac{l_{1}-u_{2}}{\left(m_{2}-u_{2}\right)-\left(m_{1}-l_{1}\right)} \text { else }\end{cases}
$$

Where $d$ is the ordinate of the highest intersection point $\mathrm{D}$ between $\mu_{M_{1}}$ and $\mu_{M_{2}}$.

To compare $M_{1}$ and, $M_{2}$ we need both the values of, $V\left(M_{1} \geq M_{2}\right)$ and $V\left(M_{2} \geq M_{1}\right)$

Step 3: The degree of possibility for a convex fuzzy number to be greater than $k$ convex fuzzy numbers $M_{i}(i=1,2, \ldots . ., k)$ can be defined by:

$V\left(M \geq M_{1}, M_{2}, \ldots \ldots ., M_{k}\right)=V\left[\left(M \geq M_{1}\right) v e\left(M \geq M_{2}\right)\right.$ ve....ve $\left.\left(M \geq M_{k}\right)\right]$

$=\min V\left(M \geq M_{i}\right), \quad i=1,2, \ldots \ldots, k$

Assume that:

$k=1,2, \ldots \ldots, n ; k \neq i$

$d^{\prime}\left(A_{i}\right)=\min V\left(S_{i} \geq S_{k}\right)$,

Then the weight vector is given by:

$W^{\prime}=\left(d^{\prime}\left(A_{1}\right), d^{\prime}\left(A_{2}\right), \ldots \ldots \ldots . . ., d^{\prime}\left(A_{n}\right)\right)^{T}$

Where $A_{i}(i=1,2, \ldots, n)$ are $n$ elements.

Step 4: Via normalization, the normalized weight vectors are:

$W=\left(d\left(A_{1}\right),\left(A_{2}\right), \ldots \ldots . . . d\left(A_{n}\right)\right)^{T}$

Where $W$ is a non-fuzzy number (Chang, 1992: 352; 1996: 649-651).

\section{b. TOPSIS Methodology}

The Technique for Order Preference by Similarity to Ideal Solution (TOPSIS), firstly introduced by Hwang and Yoon, is a multi-criteria decision making (MCDM) methodology based on the assumption that the best alternative should be as close as possible to the ideal solution and the farthest from the negative-ideal solution (Hwang and Yoon, 1981: 38-41).

The principle of compromise (of TOPSIS) for MCDM is that the chosen solution should have the shortest distance from the positive ideal solution as well as the longest dis- 
tance from the negative ideal solution.

TOPSIS defines an index called similarity to the positive- ideal solution by combining the proximity to the positive-ideal solution and remoteness from the negative-ideal solution. Then the method chooses an alternative with the maximum similarity to the positive-ideal solution. The method is presented as a series of successive steps:

Step 1: Calculate Normalized Ratings: The vector normalization is used for computing, which is given as:

$$
r_{i j}=\frac{x_{i j}}{\sqrt{\sum_{i=1}^{m} x_{i j}^{2}}} \mathrm{i}=1, \ldots, \mathrm{m} \text { ve } \mathrm{j}=1, \ldots, \mathrm{n}
$$

Step 2: Calculate Weighted Normalized Ratings: The weighted normalized value is calculated as:

$$
\mathcal{V}_{i j}=w_{j}^{*} r_{i j} \mathrm{i}=1, \ldots, \mathrm{m} ; \mathrm{j}=1, \ldots, \mathrm{n}
$$

Where ${ }^{w_{j}}$ is the weight of the $\mathrm{j}$. attribute.

Step 3: Identify positive-ideal and negative-ideal solutions: The $A^{*}$ and $A^{-}$are defined in terms of the weighted normalized values:

$$
\begin{aligned}
& A^{*}=\left\{v_{1}^{*}, v_{2}^{*}, \ldots, v_{j}^{*}, \ldots, v_{n}^{*}\right\}=\left\{\left(\max v_{i j} \mid j \in J_{1}\right),\left(\min v_{i j} \mid j \in J_{2}\right) \mid \mathrm{i}=1, \ldots, \mathrm{m}\right\}, \\
& A^{-}=\left\{v_{1}^{-}, v_{2}^{-}, \ldots, v_{j}^{-}, \ldots, v_{n}^{-}\right\}=\left\{\left(\min v_{i j} \mid j \in J_{1}\right),\left(\max v_{i j} \mid j \in J_{2}\right) \mid \mathrm{i}=1, \ldots, \mathrm{m}\right\}
\end{aligned}
$$

Where $J_{1}$ is a set of benefit attributes and $J_{2}$ is a set of cost attributes.

Step 4: Calculate Separation Measures: The separation between alternatives can be measured by the $n$ dimensional Euclidean distance. The separation of each alternative from the positive-ideal solution $A^{*}$, is then given by:

$$
\boldsymbol{S}_{i}^{*}=\sqrt{\sum_{j=1}^{n}\left(v_{i j}-v_{j}^{*}\right)^{2}}, i=1, \ldots, m .
$$

Similarly, the separation from the negative-ideal solution, $A^{-}$is given by

$$
S_{i}^{-}=\sqrt{\sum_{j=1}^{n}\left(v_{i j}-v_{j}^{-}\right)^{2}}, i=1, \ldots, m .
$$


Step 5: Calculate Similarities to Positive-Ideal Solution:

$$
C_{i}^{*}=\frac{S_{i}^{-}}{\left(S_{i}^{*}+S_{i}^{-}\right)} \quad \mathrm{i}=1, \ldots, \mathrm{m} . \quad 0 \leq C_{i}^{*} \leq 1
$$

Step 6: Rank Preference Order: Choose an alternative with the maximum $C_{i}^{*}$ or rank alternatives in descending order.

\section{Case Study: A FAHP-TOPSIS Methodology for Container Port Selection}

There are four main criteria and ten sub-criteria to select convenient container port in Ambarlı region. According to 2011 Chamber of Shipping statistics, Ambarlı Port region is the port administrative that does the maximum container handling with the $2,624,711$ TEU and $40.23 \%$ share. Ambarlı Port administrative is followed by Mersin and Gemlik with the shares \%17 and \%11.6, respectively (DTGM, 2012: 29).

As alternatives three container ports are chosen, the names of these three ports are kept anonymous and are referred to as $A, B$, and $C$ according to principle of competition. These three ports are considered as alternatives according to their container handling area, handling capacity, length of berth and draft depth. These ports are located in the same area. Thus, the criteria which are important on behalf of port selection such as geographic location, the hinterland economy, and customs were eliminated. As these ports address the same geographic location and the hinterland economy it is aimed to emphasize the importance of competitiveness. In addition, the criteria like port performance, port infrastructure, cost, information systems used in ports, and port security is selected for evaluation of the model.

Figure 1:

The Proposed Methodology

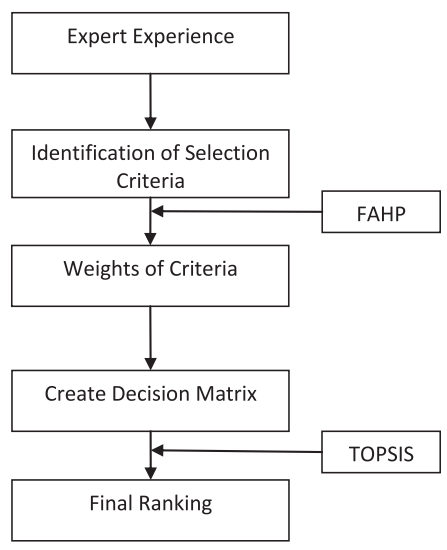


Firstly criteria for the evaluation are determined according to the DM's experience. When the evaluation criteria are identified then the FAHP method is applied to determine the weights of the criteria. Decision matrix is created. Each alternative is assessed via main and sub-criteria. TOPSIS technique is used to find the final ranking of the alternatives. The proposed methodology is summarized in Figure 1.

For determining the criteria expert opinions in shipping line firms were taken. Also there has been a literature review among the international articles. The four main criteria and the ten sub-criteria retained for the survey of global ocean carriers are given in Table 1.

Table 1:

Main criteria and sub-criteria for port selection

\begin{tabular}{|c|l|c|}
\hline MAIN CRITERIA & \multicolumn{1}{|c|}{ SUB-CRITERIA } & WEIGHT \\
\hline \multirow{2}{*}{ C1 Port Physical (PP) } & C11: Infrastructure condition (IC) & 0.50 \\
\cline { 2 - 3 } & C12: Port facilities and equipment (PFE) & 0.50 \\
\hline \multirow{4}{*}{ C2 Port Efficiency (PE) } & C21: Port berthing time length (PBTL) & 0.24 \\
\cline { 2 - 3 } & C22: Container handling efficiency (CHE) & 0.45 \\
\cline { 2 - 3 } & C23: Container yard efficiency (CYE) & 0.31 \\
\hline \multirow{2}{*}{ C3 Cost (C) } & C31: Port charge (PC) & 0.41 \\
\hline \multirow{2}{*}{ C4 0ther conditions (OC) } & C32: Cargo charge (PC) & 0.59 \\
\cline { 2 - 3 } & C41: EDI computer system (EDI) & 0.20 \\
\cline { 2 - 3 } & C43: Peod reputation related to damage and delays (GRDD) & 0.41 \\
\hline
\end{tabular}

\section{Explanations for each criteria and sub-criteria can be presented as follows:}

Port Physical (PP); including sub-criteria, Infrastructure Condition (IC), and Port Facilities and Equipment (PFE). Infrastructure Condition includes water access for the basic infrastructure of the port. Depth is the one of the major constraints which prevents the use of larger vessels to which carriers have been turning to recent years. Port Facilities and Equipment: Ports require special handling equipment (for instance reefer container services and hazardous container services) and adequate equipment capacity.

Port Efficiency (PE); including sub-criteria, Port berthing time length (PBTL), Container Handling Efficiency (CHE) Container Yard Efficiency (CYE). Port Berthing Time Length: The longer the length the faster to dock the ship and it can start loading and discharging as soon as possible. Thus, this faster loading and unloading brings the time advantage to ship owners and cargo owners. This time advantage reduces the time spent at port and also reduces the cost. And the most important thing the time advantage causes is the availability of the voyage. This also reduces the ordering costs, and loading the cargo 
faster for cargo owners. Container Handling Efficiency provides reduced waiting time for a ship at the port without changing the port infrastructure. Especially at ports that does not have an opportunity of enlargement the available capacity need to be used efficiently. For this type of ports this is the only way to increase the efficiency. To improve the container handling efficiency maximum usage of equipment and labor force is required. Container Yard Efficiency: In case of loading or discharging the LCL or FCL cargo at port the loading or discharging process occurs at Container Freight Station (CFS). The size and efficiency of CFS is important in a way that it brings time and cost advantage to import or export customers.

Cost (C); including sub-criteria as; Port Charge (PC) and Cargo Cost (CC). Port Charge includes the costs like water, oil, pilotage service etc. that the global ocean carrier pays other than the charge paid for the occupation of port. Cargo Charge consists of loading or discharging costs, temporary admission, and demurrage are some of cargo related costs. Demurrage refers to charge paid daily per a container after the period normally allowed to load and discharge cargo. The demurrage sometimes causes a loss to the seller as it increases cost of the total freight.

Other Conditions (OC); including as sub-criteria EDI Computer System (EDI), Good Reputation Related to Damage and Delays (GRDD) and Personnel Quality (PQ). EDI Computer System is an improved computer system that speeds up works, makes it easier and faster to monitor the process which means reduce cost. Good Reputation Related to Damage and Delays: Good reputation related to damage and delays; A port which damages will damage and delays transportations will not be chosen by decision makers whatever the port charges are, because delays and damages will damage the business image (Onut et al., 2011: 182-187). Personnel Quality: By personnel quality it is meant more educated workers (for example, cranes and IT-systems operators) are needed. Increased workforce will affect the operation cost and time. As the education level increases the processes at the management level will increase. Furthermore, high labor quality will attract more multinational corporations and shipping companies.

In this study there are four main criteria and ten sub-criteria. Here, three alternative container ports are considered to be evaluated as A, B, and C. The first step in the solution of the problem is comparison of the weight with criteria and alternatives. These comparisons are made according to triangle fuzzy numbers given in Table 2. 
Table 2:

Scale for FAHP Preference

\begin{tabular}{|c|c|c|}
\hline $\begin{array}{l}\text { Intensity of } \\
\text { importance }\end{array}$ & Definition & Explanation \\
\hline$(1,1,1)$ & Equal importance & Two activities contribute equally to the objective \\
\hline$(2 / 3,1,3 / 2)$ & Moderate importance & $\begin{array}{l}\text { Experience and judgement slightly favour one over } \\
\text { another }\end{array}$ \\
\hline$(3 / 2,2,5 / 2)$ & Strong importance & $\begin{array}{l}\text { Experience and judgment strongly favour one over } \\
\text { another }\end{array}$ \\
\hline$(5 / 2,3,7 / 2)$ & Very strong importance & $\begin{array}{l}\text { Activity is strongly favoured and its dominance is } \\
\text { demonstrated in practice }\end{array}$ \\
\hline$(7 / 2,4,9 / 2)$ & Absolute importance & $\begin{array}{l}\text { Importance of one over another affirmed on the } \\
\text { highest possible order }\end{array}$ \\
\hline
\end{tabular}

These comparisons can be determined according to experts' opinions or with surveys. In this study, the data is obtained by interviewing approximately 20 percent of the shipping line firms in Turkey. Comparisons and determination of weights are done by;

- Evaluation of four main criteria according to aim,

- Evaluation of sub-criteria for each main criteria,

Table 3:

Fuzzy Evaluation Matrix of Main Criteria

\begin{tabular}{|l|c|c|c|c|c|c|c|c|c|c|c|c|}
\hline & \multicolumn{3}{|c|}{ PP } & \multicolumn{3}{c|}{ PE } & \multicolumn{3}{c|}{ C } & \multicolumn{3}{c|}{ OC } \\
\hline PP & 1 & 1 & 1 & 0.51 & 0.63 & 0.82 & 0.47 & 0.63 & 0.87 & 0.56 & 0.79 & 1.14 \\
PE & 1.22 & 1.59 & 1.97 & 1 & 1 & 1 & 0.76 & 1.00 & 1.31 & 1.00 & 1.41 & 1.94 \\
C & 1.14 & 1.59 & 2.11 & 0.76 & 1.00 & 1.31 & 1 & 1 & 1 & 1.31 & 1.78 & 2.30 \\
OC & 0.80 & 1.26 & 1.78 & 0.52 & 0.71 & 1.00 & 0.44 & 0.56 & 0.76 & 1 & 1 & 1 \\
\hline
\end{tabular}

It is obtained;

$S_{P P}=(2.54,3.05,3.83) \otimes(1 / 21.31,1 / 16.95,1 / 13.58)=(0.12,0.18,0.28)$

$S_{P E}=(3.99,5.00,6.22) \otimes(1 / 21.31,1 / 16.95,1 / 13.58)=(0.19,0.30,0.46)$

$S_{C}=(4.22,5.37,6.71) \otimes(1 / 21.31,1 / 16.95,1 / 13.58)=(0.20,0.32,0.49)$

$S_{O C}=(2.83,3.53,4.54) \otimes(1 / 21.31,1 / 16.95,1 / 13.58)=(0.13,0.21,0.33)$ 
Using these vectors,

$V\left(S_{P P} \geq S_{P E}\right)=0.45, V\left(S_{P P} \geq S_{C}\right)=0.38, V\left(S_{P P} \geq S_{O C}\right)=0.84, V\left(S_{P E} \geq S_{P P}\right)=1$,

$V\left(S_{P E} \geq S_{C}\right)=0.92, V\left(S_{P E} \geq S_{O C}\right)=1, V\left(S_{C} \geq S_{P P}\right)=1, V\left(S_{C} \geq S_{P E}\right)=1, V\left(S_{C} \geq S_{O C}\right)=1$,

$V\left(S_{O C} \geq S_{P P}\right)=1, V\left(S_{O C} \geq S_{P E}\right)=0.63, V\left(S_{O C} \geq S_{C}\right)=0.56$ weight vector is calculated as

$W_{P S}=\left(\begin{array}{llll}0.13 & 0.32 & 0.35 & 0.19\end{array}\right)^{T}$.

From the criteria weights obtained by using the AHP method the weighted normalized matrix is computed as in Table 4.

Table 4:

Weighted Normalized Decision Matrix

\begin{tabular}{ccccccccccc}
\hline & IC & PFE & PBTL & CHE & CYE & PC & CC & EDI & GRDD & PQ \\
\hline PORT A & 0.29967 & 0.35969 & 0.13204 & 0.29413 & 0.21747 & 0.21492 & 0.29325 & 0.14030 & 0.26852 & 0.26963 \\
PORT B & 0.24355 & 0.26168 & 0.18485 & 0.25406 & 0.16069 & 0.25289 & 0.37184 & 0.09781 & 0.22617 & 0.20569 \\
PORT C & 0.31762 & 0.22836 & 0.07744 & 0.22681 & 0.15161 & 0.24074 & 0.35190 & 0.10367 & 0.21177 & 0.19259 \\
\hline
\end{tabular}

The results of TOPSIS analysis using FAHP weights are summarized in Table 5. Based on values, the ranking of the alternatives in descending order are Port $A, B$ and $C$. According to the last step, the best alternative is selected as Port A with the highest rank of all. The final ranking for all ports are presented in Table5.

Table 5:

Final Ranking

\begin{tabular}{cccc}
\hline & S $^{*}$ & $\mathbf{S}^{-}$ & $\mathrm{C}^{*}$ \\
\hline A & 0.10359 & 0.20491 & 0.664 \\
B & 0.17809 & 0.11998 & 0.403 \\
C & 0.21944 & 0.11474 & 0.343 \\
\hline
\end{tabular}

\section{Results}

In this study, we proposed an integrated FAHP-TOPSIS methodology for container port selection problem. This model is applied in Ambarlı Port region for three container ports. With the highest value of 0.664 Port $A$ is ranked as the first alternative to be selected. Other two alternatives are ranked as Port B and Port $C$ having the scores of 0.403 and 0.343 , respectively. The reason for Port A to be ranked as the first port among other alternatives is this port especially gets high evaluation from the criteria, like port 
efficiency; on the other side it has low performance on cost. Since these results coincide with the real data this integrated FAHP-TOPSIS methodology is compromising.

The results may be taken into consideration by port managers and government departments of marine transportation. Based on these results, port managers can further develop useful operational strategies and government departments of marine transportation also can make some significant port policies to improve the competence among ports.

In future studies, other decision-making methods can also be included in the methodology to ensure more integrated and/or comparative study. Different alternative methodologies such as ANP, TOPSIS, ELECTRE, Fuzzy ANP, fuzzy TOPSIS and fuzzy ELECTRE can be implicated. Also, another study can be done by using the same selection criteria between ports in different region of Turkey but serve the same hinterland. In addition, by changing a portion of the selection criteria used in this study a selection for appropriate transshipment port can be done. In addition, a different research can be done by creating separate working groups with ship owners, freight forwarders, and cargo owners to understand what they care about most on behalf of port selection.

\section{REFERENCES}

Alonsoz, Lorena, Jose Angel Vallejo and Veldman Simme (2011) “Determinants of Container Port Choice in Spain”, Maritime Policy and Management, 38(5), p.509-522.

Beresford , Anthony K.C., Taih-Cherng Lirn and Helen Thanopoulou (2003) "Transshipment Port Selection and Decision Making Behavior: Analyzing the Taiwanese Case", International Journal of Logistics, 6(4), p.229-244.

Beresford , Anthony K.C., Malcolm James Beynon, Taih-Cherng Lirn, and Helen Thanopoulou (2004) "An Application of AHP on Transshipment Port Selection: A Global Perspective", Maritime Economics \& Logistics, 6(1),p.70-91.

Brian, Slack (1985) "Containerization: Inter-Port Competition And Port Selection”, Maritime Policy and Management, 12(4), p.293-303.

Chang, Da Yong (1992) “Extent Analysis and Synthetic Decision”, in Optimization Techniques and Applications Vol. 1, Singapore: World Scientific, p. 352.

Chang, Da Yong (1996) "Applications of the Extent Analysis Method on Fuzzy AHP”, European Journal of Operational Research, 95(3), p.649-655. 
Chang, Young-Tae, Sang-Yoon Lee and Jose L. Tongzon (2008) “Port Selection Factors by Shipping Lines: Different Perspectives Between Trunk Liners and Feeder Service Providers", Marine Policy, 32(6), p.877-885.

Chou, Chien-Chang (2007) “A Fuzzy MCDM method for Solving Marine Transshipment Container Port Selection Problems", Applied Mathematics and Computation, 186(1), p.435-444.

Chou, Chien-Chang (2010) “AHP Model for the Container Port Choice in the Multiple-Ports Region”, Journal of Marine Science and Technology, 18(2), p.221-232.

Chou, Chien-Chang, Fu-Tsuan Kuo, Rong-Hua Gou, Chaur-Luh Tsai, Chun-Pong Wong and Ming-Cheng Tsou (2010) “Application of a Combined Fuzzy Multiple Criteria Decision Making and Optimization Programming Model on the Container Transportation Demand Split", Applied Soft Computing, 10, p.1080-1086.

Dai, Jing, and Jasmine Siu Lee Lam (2012) “A Decision Support System for Port Selection", Transportation Planning and Technology, 35(4), p.509-524.

Deniz Ticareti Genel Müdürlüğü (2013) Deniz Ticareti Istatistikleri, Ankara.

Huiyuan, Jiang, Lu Shengrong and Liu Yao (2010) “Port Competitiveness Evaluation Research Based on Combined Model of Cluster and TOPSIS Analysis", paper presented in International Conference on Environmental Science and Information Application Technology (ESIAT), 17-18 July 2010, Wuhan, China.

Hwang, Ching Lai, and Paul Yoon (1981) Multiple Attribute Decision Making Methods and Applications, New York: Springer-Verlag.

Onut, Semih, Umut R. Tuzkaya, and Erçin Torun(2011) “Selecting Container Port via a Fuzzy ANP-Based Approach: A Case Study in the Marmara Region Turkey", Transport Policy, c(s), p.182-193.

Sawant, Lavina and Jose L. Tongzon (2007) "Port Choice in a Competitive Environment: From the Shipping Lines' Perspective", Applied Economics, 39(4-6), p.477-492.

Tongzon, Jose, L. (2009) "Port Choice and Freight Forwarders", Transportation Research Part E-Logistics and Transportation Review, 45(1), p.186-195.

Tran, Nguyen Khoi (2011) “Studying Port Selection on Liner Routes: An Approach from Logistics Perspective", Research In Transportation Economics, 32(2011), p.39-53. 
Ugboma, Chinonye, Ogochukwu Ugboma and Innocent C. Ogwude (2006) “An Analytic Hierarchy Process (AHP) Approach to Port Selection Decisions - Empirical Evidence from Nigerian Ports", Maritime Economics \& Logistics, 8, p.251-266.

United Nations Conference on Trade and Development (2012) Review of Maritime Transport. 


\title{
TÜRKİYE'DE YAT VE MARİNA İŞLETMECİLİĞİ: İSTİHDAM DEĞERLENDİRMESİ İÇİN MEVCUT DURUM ANALİZí
}

\author{
GÖKÇE YÜKSEK (1)
}

\begin{abstract}
ÖZ
Ülkemizde yat turizmi hızla gelișmektedir. Her geçen gün artan turist sayısı, yapılan marina yatırımları bu sektörde önemli bir istihdam yaratmaktadır. Yat ve marina ișletmelerinde çalıșan nitelikli ara eleman sayısı yetersizdir. Buna rağmen, sektörde bu alanda eğitim veren üniversite mezunları istihdam edilmemektedir. Sektörde düșük ücret politikası nitelikli ara eleman bulmayı zorlaștırmaktadır. Yat ve marina sektöründeki gelecek tahminleri daha fazla eleman ihtiyacı olacağını göstermektedir. Bu araștırmada, Türkiye'de hızla gelișen yat turizmi sektörünün en önemli bileșenlerinden biri olan yat ve marina ișletmeciliğini incelenerek, istihdam konusu değerlendirilmiș ve çözüm önerilerinde bulunulmuștur.
\end{abstract}

Anahtar Kelimeler: Yat turizmi, marina ișletmeciliği, yat ișletmeciliği, marinalarda istihdam, deniz ișletmeciliği

JEL Kodları: L91, L99, E24, R41

\section{ABSTRACT}

Yacht tourism is still developing in our country. Increasing number of tourists and marina investments create a considerable employment in this sector. Number of qualified intermediate staff employed in yacht and marine business administrations are still inadequate. However, graduates of universities providing education on yacht and marine business are not employed by the sector. Low-wage policy in the sector obstructs to find qualified intermediate personnel. Future forecasts indicate the need for employees will increase in the yacht and marine sector. In this study, yacht and marine business administration is investigated, as one of the most important components in yacht tourism sector rapidly growing in Turkey, by evaluating employment issues and possible solutions are discussed.

Keywords: Yacht tourism, marine business, yacht business, employment in marines, maritime business.

JEL Codes: L91, L99, E24, R41

1 Yrd. Doç. Dr., Anadolu Üniversitesi, gozeráanadolu.edu.tr 


\section{Giriș}

Yat ișletmeciliğinin son 20 yıl içerisinde büyümesi ve modern marinacılık hizmetlerinin yaygınlașması ile ülkemizin kıyı bandında bulunan yerleșim merkezlerinde marina yatırımları çoğalmıș ve mevcut balıkçı barınakları bile marina haline getirilmeye çalıșılmıștır.

Turizm endüstrisinin önemli bir sektörü olan deniz turizmi, ülkemizin sahip olduğu denizler ve kıyı șeridi ve artan potansiyeliyle gün geçtikçe daha büyük bir ilgi yaratmakta ve turizm gelirlerinde artan bir pay elde etmektedir. Türk limanlarına kayıtlı özel ve ticari yatların ve marinaların sayılarının ve kapasitelerinin artıșı ve yabancı bayraklı yatların Türkiye kıyılarına artan ilgisi beraberinde sektörde çalıșan personelin sadece niceliksel değil niteliksel olarak da bir gelișme beklentisini de beraberinde getirmiștir. Özellikle deniz turizminde, yatçılık ve marina ișletmeciliği alanlarında yașanılan hızlı gelișim süreci, sektörün bu alanlarda yetișmiș personele duyduğu ihtiyacı ön plana çıkarmıștır. Dolayısıyla, bugün bu sektörün Deniz Ticaret Odası ve Bakanlıkların mevcut düzenlemeleri gelișmesi mümkün değildir.

\section{Yat ve Marina İșletmeciliği}

Dünyanın küreselleșmesinde önemli olan denizler, başlangıçtan bu yana turizm endüstrisinin temel ürünü ve önemli bir cazibe noktası olmuștur. Türkiye ise bulunduğu konum itibari ile dünyada denizcilik alanında önemli cazibe noktalarından biri olarak yer almaktadır. Birçok ekonomik alanda olduğu gibi turizm alanında da denizin kullanımı uluslararası pazarlarda Türkiye'ye rekabette üstünlük sağlamaktadır (Eriș, 2007: 37). Ülkemizde Deniz Turizmi, talebin en yüksek olduğu turizm çeșitlerinden biridir. Ülkemizde Deniz Turizmi gelirleri, turizm gelirlerinin yaklașık \%20’sini olușturmaktadır. 2010 yılı verileri itibariyle deniz turizminden 4.16 milyar dolarlık yıllık gelir elde edilmektedir. Deniz Turizmi iki temel bileșenden olușur (DTO, 2010: 131):

Deniz Turizmi Araçları: Özel ve ticari yatlar, Kruvaziyer gemiler, Günübirlik gezi tekneleri, Yüzer tesisler, Sualtı ve su üstü sporları araçları, Diğer deniz turizmi araçları.

Deniz Turizmi Tesisleri: Yat limanları, Kruvaziyer limanlar, Bağlama yerleri, İskeleler, Diğer deniz turizmi tesisleri.

\section{a. Yat İșletmeciliği}

Yat, deniz yolu taşımacılığına uygun donanıma ve teknik özelliklere göre gidebileceği mesafenin belirlendiği, önemli gereksinimlere yanıt verebilecek üniteleri bulunan, deneyimli mürettebata sahip turizm ve seyahat aracıdır. Yatlar, yelkenli ve motor yat ol- 
mak üzere ikiye ayrılır. Bunların dıșında bir de ülkemizde kullanılan ve ülkemize özgü olan guletler vardır. Guletler, yelkenli yat sınıfına giren fakat motor ve yelken donanımlı, özel bir tasarıma sahip ahșap gezi teknelerdir. Kültür ve Turizm Bakanlığı tarafından cııkarılan deniz turizmi yönetmeliğine göre ise yatlar; yelkenli, motorlu ve yelkenli ve motorlu yatların özelliklerini tașıyan karma yatlar olmak üzere üç grupta sınıflandırılmaktadır (Yüksek, 2010: 83).

Yelkenli ve motor yatlar ve guletlerden bașka, mega yatlar bulunmaktadır. 30-60 metre boyunda, (1990 yılından sonra 50 metre ve üzerindeki yatlara mega yat denilmiștir) ortalama yolcu bașına bir personel bulunduran, teknik ve estetik özellikleri beş yıldız otellerden üstün olan teknelere ise mega yat adı verilmektedir. Mega yatların müșteri profilleri çok yüksek gelir grubuna dâhil olduğundan döviz getirileri çok yüksektir. Ülkemizde son yıllarda ihraç edilmek üzere inșa edilen mega yat sayısı giderek artmakta ve milyar dolarlık bir sektör haline gelmektedir.

Yatlar, sahip oldukları özellikler bakımından yolcu gemilerinden farklılık gösterir. Yolcu gemilerinde temel amaç yolcuların konforlu bir șekilde ulaşımlarını sağlamak iken, yatlarda gezi, dinlenme, spor, macera gibi amaçlar olabilir. Yolcu gemileri sadece ticari amaçlarla kullanılırken, yatlar hem ticari hem de özel amaçlarla kullanılır. Ayrıca, yolcu gemileri yolcu tașıma kapasiteleri ve limanlara uğrama zorunlulukları varken, yatların yolcu kapasiteleri azdır ve limanlara uğrama zorunlulukları yoktur. Son olarak yolcu gemilerinde çalıșan personelin görevleri belirlenmiș ve sınırlandırılmıștır, yatlarda ise personelin görevlerinin kesin sınırları yoktur.

Yatçılık ise limanlar arasında, düzenli yolcu ulaşımını sağlamaktan çok, gezi, spor ve eğlence amacıyla, az sayıda kișinin hizmetine sunulan, görece pek büyük olmayan gemilerle yapılan turistik bir faaliyettir.

4.8.1983 Tarih ve 18125 Sayılı Resmi Gazetede yayımlanarak yürürlüğe giren Yat Turizmi Yönetmeliği günümüzde deniz turizminin hızlı gelișimi ve meslek dallarının çeșitlenmesi ve bahse konu Turizm Teșvik Kanununun değișmesi sonucu yetersiz kalması sebebiyle Kültür ve Turizm Bakanlığı koordinasyonunda diğer kamu ve sektör temsilcileri ve odası Deniz Turizmi Yönetmelik Taslağı çalıșmaları tamamlanarak Deniz Turizmi Yönetmeliği 24.07.2009 Tarih ve 27298 (Asıl) Sayılı Resmi Gazetede yayımlanarak yürürlüğe girmiștir (DTO, 2010: 132). Deniz Turizmi Yönetmeliğine göre yat işletmeleri, sahip oldukları veya kiraladıkları yerli ve yabancı bayraklı yatların mürettebatlı ve mürettebatsız olarak yönetmelikte belirtilen șartlarla gezi, eğlence ve spor amaçlı kullanımları için yatçıların geçici kullanımlarına vererek faaliyette bulunan, Bakanlıktan belgeli yatırım ve ișletmelerdir (Deniz Turizmi Yönetmeliği, 2012).

Yat ișletmeciliği yapan firmalar, seyahat acentaları ve tur operatörleri ile çalıșırlar ve 
denizcilikle ilgili konularda faaliyet gösterirler. Yat limanları, çekek yerleri kurabilir, deniz malzemeleri satabilir ve marina ișletmeciliği yapabilirler, ancak seyahat acentacılığı faaliyetinde bulunamazlar (Arıkan ve Ahipașaoğlu, 2005: 102).

Ülkemize gelen turistler, bareboat (mürettebatsız) ya da mürettebatlı tekneler kiralayarak kıyılarımızda gezinti yapma imkânına sahiptir. Mürettebatlı teknelerin büyük bir kısmı olan guletler ise ülkemize özgü bir seyahat ve tatil türü olan Mavi Yolculuk turizmini yaratmıștır. Bu konuda gerek turistlerin can ve mal güvenliği, gerek deniz kirliliği, gerekse haksız rekabetin önlenmesi ve mavi yolculuğun geleceğinin güvence altına alınması için ciddi bir kontrol sistemine ve yeni uygulanabilir kurallara ihtiyaç vardır.

\section{b. Marina İșletmeciliği}

Marina (yat limanı), küçük teknelerin ve yatların barınmaları için inșa edilmiș, yatların bakım ve onarımının yanı sıra, elektrik, su, telefon, lokanta, alıș-veriș vs. hizmetlerin sağlandığı turizme açık tesislerdir (Arıkan ve Ahipașaoğlu, 2005: 101). Bașka bir tanıma göre ise yat limanları (marinalar) ve çekek yerleri, kıyıda ve deniz içinde yapılması zorunlu, yerli ve yabancı yatlara bağlama, su, elektrik, kumanya veya kıșlama gibi hizmetler sunan kıyı tesisleridir (Olgaç, 2001: 5). Yat limanları açıklanırken bilinmesi gereken iki kavram da yat yanașma yeri ve yat çekek yeridir.

Yat yanaşma yeri; yeterli su derinliğine sahip yatların bağlanabilecekleri ve yatçıların yatlarından yürüyerek çıkabilmelerine olanak sağlayan iskelelere, dinlenme, yatlara bakım, onarım, yeme, içme ve alıș veriş gibi sosyal ünitelere sahip deniz turizmi liman tesisleridir.

Yat çekek yeri; yatlara, güvenli bir șekilde karaya çekme, bakım ve onarım hizmetleri ile denize indirme hizmetleri sunan deniz turizmi tesisleridir.

Yat limanları, tamir ve bakım, yakıt haberleșme ve alıș veriș hizmetleri yanında büyük merkezlere ve dinlence eğlence, yiyecek-içecek vb. hizmetleri sağlayan tesisler olduğundan konaklama sektörü içinde düșünülmektedir. Yat limanları;

- Direk liman hizmetleri; bağlama demirleme, kayıt ișlemleri, gemi bağlama için yeterli alan, hava koșullarından koruyucu bir yapı, park alanları, kıșın konaklama alanları, ülkeye giriș noktaları vb.

- Dolaylı liman hizmetleri, temiz su sağlama, yakıt ve elektrik gereksinimlerini sağlama, güncel iletișim sistemleri, güvenlik, atık su gibi,

- Gümrük ve yönetim ofisi gibi yönetim hizmetleri,

- Bakım ve onarım hizmetleri,

- Turiste yönelik diğer hizmetleri (restoran, temizlik hizmetleri, banka, eczane, sağlık vb. hizmetler verirler. 
Yat limanları, deniz turizmi yönetmeliğinde belirlenen bu alt ve üstyapı niteliklerine ve bunlara ilave olarak sağladıkları imkânlara göre sınıflandırılır ve belgelendirilir. Yat limanları; üç çıpalı yat limanları, dört çıpalı yat limanları, beș çıpalı yat limanları olarak üçe ayrılır (Deniz Turizmi Yönetmeliği, 2012).

Üc cıpalı yat limanları: Yukarıda açıklanan alt yapı ve üst yapı niteliklerinin yanı sıra aşağıda belirtilen nitelikleri de tașır:

1. Satıș üniteleri

2. Kadın ve erkek yatçılar için bağlama kapasitesinin en az \%5'i kadar duș ve tuvalet

3. Camașır ve bulașık yıkama yerleri

4. Yatçıların dinlenmelerini ve bir arada bulunmalarını sağlayan sosyal tesis

5. Bedensel engelliler için tuvalet ve özel düzenlemeler.

Dört çıpalı yat limanları: Üç çıpalı yat limanları için aranan șartların yanı sıra așağıda belirtilen nitelikleri tașır:

1. Lokanta veya kafeterya

2. Kadın ve erkek yatçılar için bağlama kapasitesinin en az \%10'u kadar duș ve tuvalet

3. Kuru temizleme hizmeti.

4. Yat çekek alanı ve vinç sistemleri

5. Bakım onarım hizmeti

6. Yatçı eșya depoları

7. Bağlama kapasitesinin en az \%20'si kadar otopark alanı veya otopark hizmeti

8. Tenis kortu

9. Yüzme havuzu veya plaj yeri

10. Aletli jimnastik, masaj, sauna, hamam imkânlarının sağlandığı üniteler.

Beș çıpalı yat limanları: Dört çıpalı yat limanları için aranan şartların yanı sıra aşağıda belirtilen nitelikleri tașır:

1. Helikopter pisti

2. Banka hizmetleri ünitesi

3. Revir

4. Sergi, konser, eğlence mekânları

5. Toplantı salonu

6. En az iki tenis kortu

7. Bağlama kapasitesinin en az \%30'u kadar otopark.

\section{Araștırmanın Amacı ve Yöntemi}

Bu araștırmanın amacı ülkemizde hızla gelișen deniz turizmi sektörünün en önemli bileșenlerinden biri olan yat ve marina ișletmeciliğinin mevcut durumunu inceleyerek, istihdam sorunlarını tespit etmek ve çözüm önerilerinde bulunmaktır. 
Türkiye'de yat ve marina ișletmelerine yönelik yatırımlar hızla devam ederken kalifiye ara eleman sıkıntısı mevcuttur. Deniz Ticaret Odası ve Kültür ve Turizm Bakanlığı'nın geleceğe yönelik bilimsel tahmin yöntemlerinin sonuçları ve yapılacak yatırımların bilgileri göstermektedir ki ülkemizde mevcut deniz turizmi ve denizciliğe yönelik açılan eğitim kurumlarından mezun olan personelin sayısı, günümüzdeki yat ve marina ișletmeleri ve gelecekte açılacak bu ișletmelerin ihtiyacını ve ülkemize gelmesi tahmin edilen yat ve turist sayısını karșılamayacaktır. Bu problem doğrultusunda betimsel analiz yapılan çalıșmada veri toplama aracı olarak "görüșme formu” kullanılmıștır. Araștırmanın çerçevesi 4 aşamadan olușmaktadır. İlk aşamada betimsel analiz için bir kavramsal bir çerçeve olușturulmuș, yat ve marina ișletmeciliğine ve istihdama yönelik literatür taraması yapılmıș, Türkiye' de yat ve marina ișletmeciliğine yönelik ikincil veri kaynaklarına ulașılmıștır. Verilere ulașmada kaynak taraması yanında Türkiye'deki marinaların istihdam sorunlarına yönelik 6 sorudan oluşan görüșme formu hazırlanarak iki marina yöneticisine doldurtulmuștur (D-Marin Marinalar Koordinatörü ve Setur Kușadası Marina Müdürül. İkinci olarak bu veriler kavramsal çerçeveye göre sınıflandırılarak mevcut durum betimlenmeye çalıșılmıștır. Üçüncü aşamada betimsel analizin sonucunda elde edilen bulgular ortaya konmuștur. Son așamada ise bulgular yorumlanarak araștırma problemine çözüm önerisinde bulunulmuștur.

\section{a. Türkiye'de Yat ve Marina İșletmeciliği Mevcut Durum Analizi}

Deniz turizmi sektörü hızla gelișmekte olan ülkemizde yatçılık ve marina ișletmeciliği büyük bir öneme sahiptir. Bunun yanında Akdeniz çanağı ve Avrupa ülkelerinin kıyı uzunlukları ve yat limanlarına ve yat trafiklerine bakıldığında henüz yapılacak çok șeyin olduğu söylenebilir. Bugün ülkemizde Bakanlık belgeli toplam 76 ișletme, 959 yat ve 8091 yatak kapasitesi mevcuttur (Bakınız Tablo 1). Tablo 1'de ülkemizdeki yat yatırım belgeli ișletmelerin sayısında son yıllarda bir düșüș olduğu görülmektedir. Bu sektörün bu anlamda yeteri kadar beslendiğine yorumlanabileceği gibi bu konunun göz ardı edilemeye başlandığı șeklinde de yorumlanabilir.

Tablo 1:

Bakanlık Belgeli Yat İșletmeleri ve Yatak Sayıları

\begin{tabular}{|c|c|c|c|c|c|c|c|c|c|}
\hline & \multicolumn{3}{|c|}{ ISSLETME SAYISI } & \multicolumn{3}{c|}{ YAT SAYISI } & \multicolumn{3}{c|}{ YATAK SAYISI } \\
\hline YILLAR & YERLI & YABANCI & TOPLAM & YERLI & YABANCI & TOPLAM & YERLI & YABANCI & TOPLAM \\
\hline $\mathbf{1 9 8 6}$ & 36 & 21 & $\mathbf{5 7}$ & 226 & 378 & $\mathbf{6 0 4}$ & 2402 & 2515 & $\mathbf{4 9 1 7}$ \\
\hline $\mathbf{1 9 8 7}$ & 52 & 19 & $\mathbf{7 1}$ & 360 & 375 & $\mathbf{7 3 5}$ & 3360 & 2769 & $\mathbf{6 1 2 9}$ \\
\hline $\mathbf{1 9 8 8}$ & $\mathbf{7 3}$ & 20 & $\mathbf{9 3}$ & 473 & 527 & $\mathbf{1 0 0 0}$ & 4431 & 3816 & $\mathbf{8 2 4 7}$ \\
\hline $\mathbf{1 9 8 9}$ & 83 & 24 & $\mathbf{1 0 7}$ & 544 & 623 & $\mathbf{1 1 6 7}$ & 4964 & 4394 & $\mathbf{9 3 5 8}$ \\
\hline
\end{tabular}




\begin{tabular}{|c|c|c|c|c|c|c|c|c|c|}
\hline 1990 & 84 & 24 & 108 & 441 & 583 & 1024 & 4365 & 4102 & 8467 \\
\hline 1991 & 88 & 19 & 107 & 460 & 403 & 863 & 4559 & 2846 & 7405 \\
\hline 1992 & 93 & 18 & 111 & 481 & 523 & 1004 & 4971 & 3609 & 8580 \\
\hline 1993 & 95 & 18 & 113 & 474 & 553 & 1027 & 5034 & 3732 & 8766 \\
\hline 1994 & 99 & 15 & 114 & 524 & 498 & 1022 & 5401 & 3243 & 8644 \\
\hline 1995 & 98 & 11 & 109 & 547 & 412 & 959 & 5567 & 2616 & 8183 \\
\hline 1996 & 98 & 10 & 108 & 585 & 398 & 983 & 5905 & 2542 & 8447 \\
\hline 1997 & 99 & 7 & 106 & 606 & 393 & 999 & 6071 & 2479 & 8550 \\
\hline 1998 & 100 & 8 & 108 & 618 & 414 & 1032 & 6100 & 2557 & 8657 \\
\hline 1999 & 101 & 9 & 110 & 612 & 410 & 1022 & 6013 & 2573 & 8586 \\
\hline 2000 & 100 & 10 & 110 & 817 & 455 & 1272 & 7378 & 2856 & 10234 \\
\hline 2001 & 98 & 10 & 108 & 821 & 480 & 1301 & 7404 & 2977 & 10381 \\
\hline 2002 & 96 & 10 & 106 & 725 & 369 & 1094 & 6774 & 2457 & 9231 \\
\hline 2003 & 97 & 9 & 106 & 725 & 333 & 1058 & 6905 & 2329 & 9234 \\
\hline 2004 & 83 & 8 & 91 & 699 & 294 & 993 & 6377 & 2110 & 8487 \\
\hline 2005 & 76 & 10 & 86 & 723 & 345 & 1068 & 6394 & 2486 & 8880 \\
\hline 2006 & 60 & 11 & 71 & 666 & 395 & 1061 & 5398 & 2764 & 8162 \\
\hline 2007 & 58 & 11 & 69 & 845 & 381 & 1226 & 6764 & 2748 & 9512 \\
\hline 2008 & 61 & 15 & 76 & 990 & 431 & 1421 & 8051 & 3116 & 11167 \\
\hline 2009 & 53 & 18 & 71 & 943 & 433 & 1376 & 7443 & 3191 & 10634 \\
\hline 2010 & 59 & 17 & 76 & 521 & 438 & 959 & 4851 & 3240 & 8091 \\
\hline 2011 & 60 & 17 & 77 & 512 & 438 & 959 & 4853 & 3240 & 8093 \\
\hline
\end{tabular}

Kaynak: Kültür ve Turizm Bakanlığı

T.C. Ulaștırma, Denizcilik ve Haberleșme bakanlığı tarafından hazırlatılan Turizm Kıyı Yapıları Master Plan Çalıșmasında talebin belirlenmesine yönelik regresyon analizi yapılarak bu analizde iki yol izlenmiștir. Bunlardan ilki Türkiye genelinde (makro) tahminleme (Șekil 1) diğeri ise bölgesel bazda (mikro) tahminlemelerdir (Șekil 2). Makro tahminleme gerçekleșen toplam yat sayısı üzerinden hesaplanırken mikro tahminlemede bölgesel bazda gerçekleșen gemi, yolcu ve yat hesaplamaları üzerinden gerçekleștirilmiștir (T.C. Ulaștırma Bakanlığı, 2010: 101). 
Sekil 1:

Türkiye Geneli Toplam Yat Yolcu Talep Tahmin Modeli

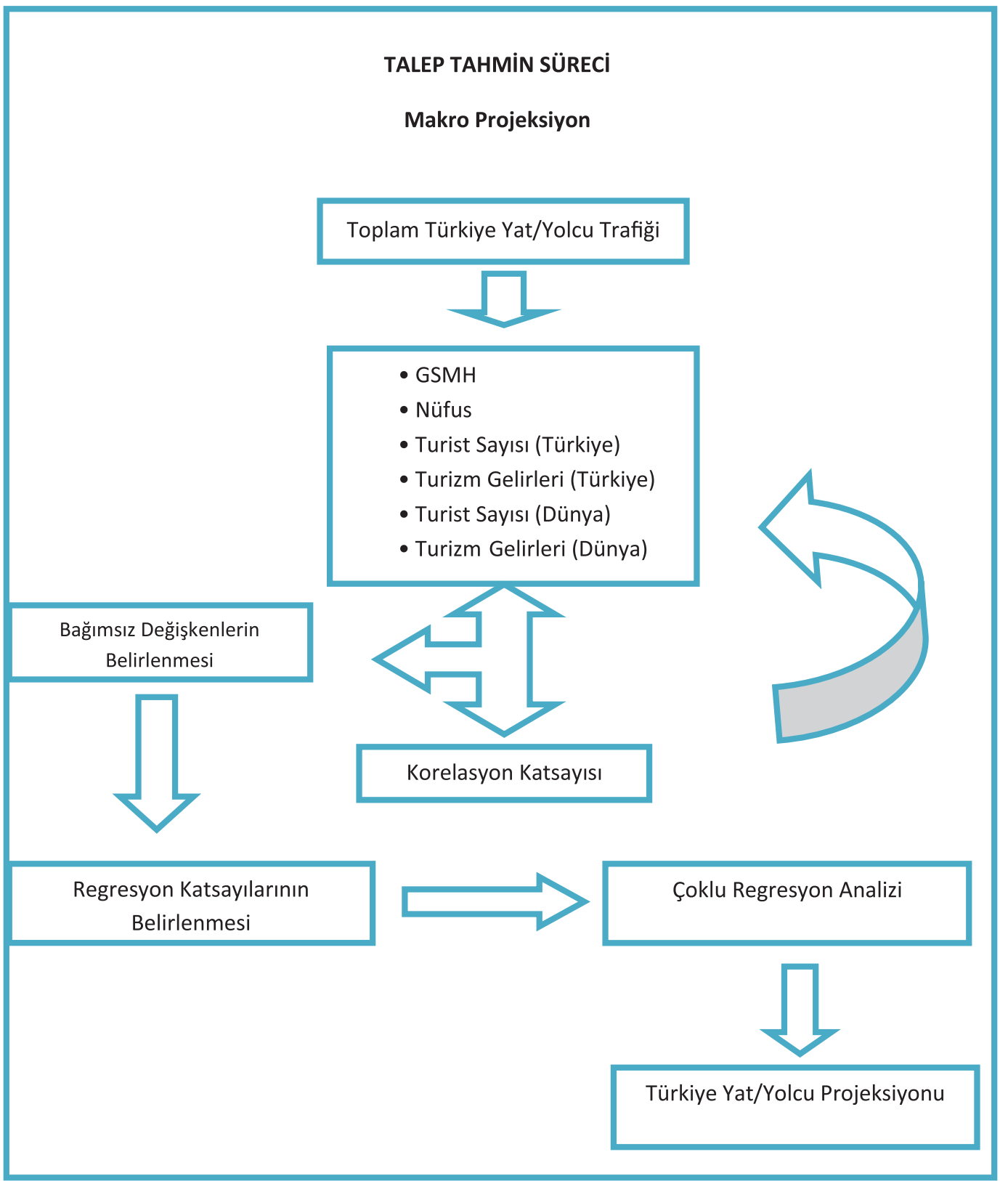

Kaynak: T.C. Ulaștırma Bakanlığı, 2010: 102 
Sekil 2:

Bölgeler Bazında Yat Yolcu Talep Tahmin Modeli

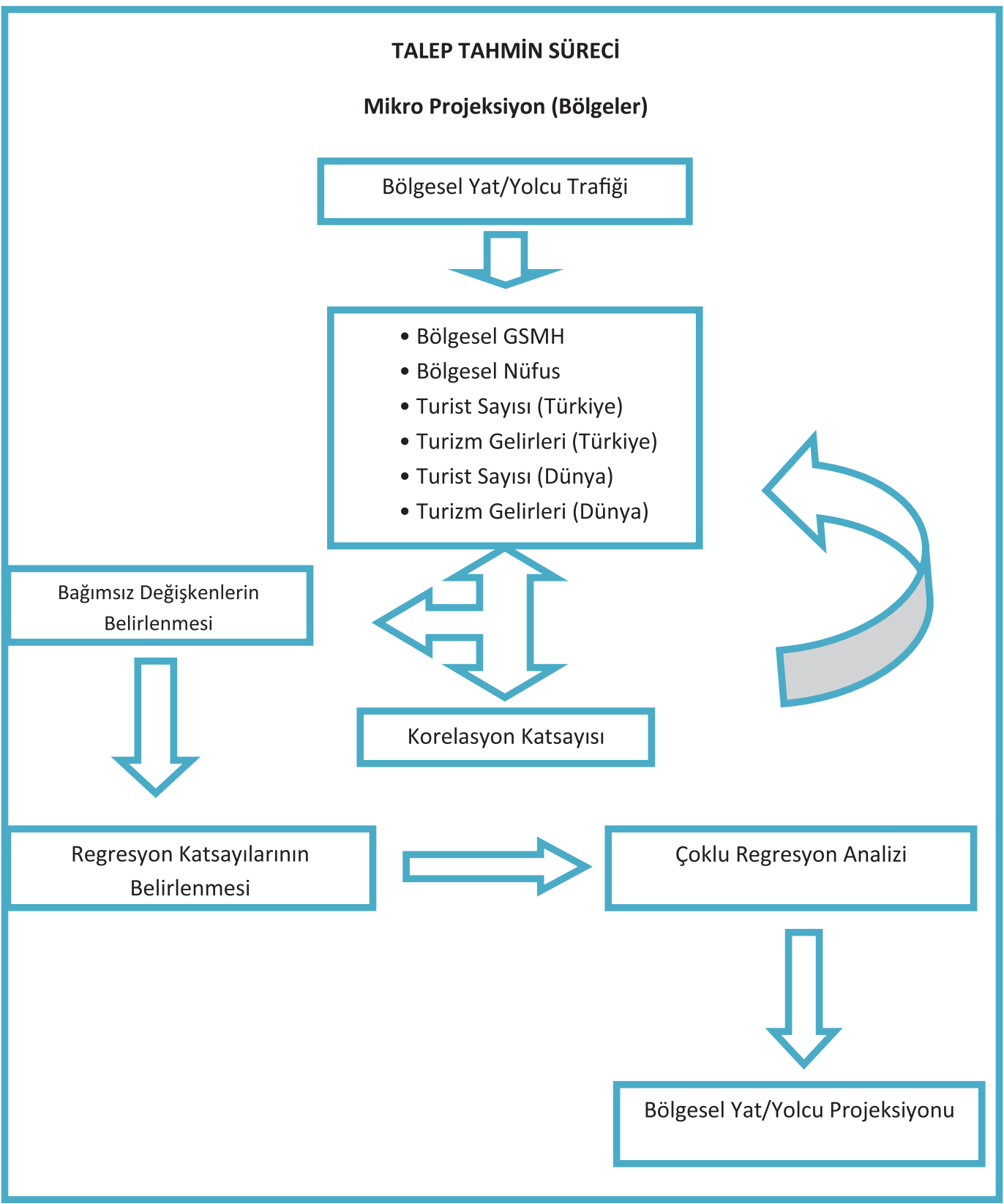

Kaynak: T.C. Ulaștırma Bakanlığı, 2010: 103

Türkiye deki toplam (Türk ve yabancı bayraklı) yat sayısının belirlenmesinde yararlanılan regresyon analizinde bağımlı değișken olarak yat sayısı, bağımsız değișken olarak en yüksek korelasyon sayısını veren turizm gelirleri, toplam turist sayısı (Türkiye ve 
Dünyal kullanılmıștır. GSMH ve nüfus ile yat sayısı arasındaki ilișki düşük seviyede bulunmuş bu nedenle kullanılmamıștır. Gerek Türkiye geneli gerekse bölgeler bazında tüm tahmin analizleri kötümser, ortalama ve iyimser senaryolar altında incelenmiștir. İlk așamada yat sayısı tüm Türkiye üzerinden tahminlenmiș, daha sonra bölgeler bazında hesaplanan yıllara göre yat talep tahmininden tekrar Türkiye genel yat talep tahminine ulașılmıștır (T.C. Ulaștırma Bakanlığı, 2010: 104). Yapılan bu tahminler önümüzdeki 20 yıl içinde yat sayılarında önemli bir artıș olacağını göstermektedir (Tablo 2 ve 3).

Tablo 2:

Türkiye Geneli Yat Talep Tahmini (Mikro Projeksiyon)

\begin{tabular}{|c|c|c|c|}
\hline Yıllar & Kötümser & Ortalama & iyimser \\
\hline $\mathbf{2 0 1 5}$ & 18008 & 19911 & 21944 \\
\hline $\mathbf{2 0 2 0}$ & 22022 & 26816 & 32043 \\
\hline $\mathbf{2 0 2 5}$ & 26828 & 36197 & 46441 \\
\hline $\mathbf{2 0 3 0}$ & 32631 & 48890 & 66843 \\
\hline
\end{tabular}

Kaynak: T.C. Ulaștırma Bakanlığı, 2010.

Tahmin edilen tüm değerler yeterli yat bağlama kapasitesinin zamanında arzı ile mümkün olabilecektir. Zira yat turizminde gelișimin önündeki en önemli sınırlayıcı parametre liman kapasiteleridir. Gelișme ancak liman kapasitelerinin yat artıșına paralel arttırılması ile mümkün olabilecektir. Makro ve mikro projeksiyonlarda hesaplanan yat sayıları arasındaki farkın en önemli nedeni Türkiye genelindeki artıșın bölgeler bazındaki artıștan daha yüksek olmasıdır.

Tablo 3:

Türkiye Geneli Yat Talep Tahmini (Makro Projeksiyon)

\begin{tabular}{|c|c|c|c|}
\hline Yıllar & Kötümser & Ortalama & Iyimser \\
\hline $\mathbf{2 0 1 5}$ & 17.648 & 20.467 & 23.281 \\
\hline $\mathbf{2 0 2 0}$ & 20.791 & 27.277 & 34.114 \\
\hline $\mathbf{2 0 2 5}$ & 23.880 & 35.442 & 48.144 \\
\hline $\mathbf{2 0 3 0}$ & 26.811 & 45.012 & 65.768 \\
\hline
\end{tabular}

Kaynak : T.C. Ulaștırma Bakanlığı, 2010.

Mevcut yat limanlarının toplam kapasitesi 15.526 adet değișik boy ve özellikte yattır. En kötü senaryo göz önüne alınsa bile Türkiye deki yat bağlama kapasitesinin iki katına çıkarılması gerekmektedir. Ülkemizde bir kısım balıkçı barınağı hali hazırda yatlara barınma hizmeti vermektedir. Bir bölüm yat ise belediye iskelelerinde, çekek yerlerinde veya korunumlu koylarda barınmaktadır. Yat limanı sayısının artması ile söz konusu yatlarında yat limanlarına geleceği öngörülmektedir. Türkiye geneli toplam yat verileri 
üzerinden gerçekleștirilen makro projeksiyonlarda yat trafiğinin yirmi yıl içerisinde üç katına çıkacağı tahminlenmiștir. Bunun bașlıca nedeni kapasite artıșının talep artıșını tetikleyecek olmasıdır (Turizm Kıyı Yapıları Master Plan Çalıșması Sonuç Raporu, 2010: 105).

Yine Turizm Kıyı Yapıları Master Plan Çalıșması Sonuç Raporunda (2010) verilen bilgilere göre regresyon yöntemi ile yapılan limanlarımıza giriș yapacak yatların sayısı tahminlenmiștir. 2030 yılında yaklașık 200.000 yatın (transit log ve sarı bayraklı yatlar) limanlarımıza giriș yapacağı belirtilmektedir.

Tablo 4 incelendiğinde, yatırım belgeli yat ișletmeleri ve yat sayılarının son yıllarda azalmakta olduğu görülür. 2000'li yılların bașlarında sayısal olarak pek fazla dalgalanma göstermeyen rakamların son dönemlerde keskin bir șekildeki azalıșı dikkat çekmektedir.

Tablo 4:

Yat Yatırım Belgeli İșletmeler

\begin{tabular}{|c|c|c|c|}
\hline Yıllar & İșletme Sayısı & Yat Sayısı & Yatak Sayısı \\
\hline $\mathbf{2 0 0 0}$ & 72 & 325 & 3642 \\
\hline $\mathbf{2 0 0 1}$ & 69 & 307 & 3551 \\
\hline $\mathbf{2 0 0 2}$ & 52 & 234 & 2645 \\
\hline $\mathbf{2 0 0 3}$ & 52 & 234 & 2645 \\
\hline $\mathbf{2 0 0 4}$ & 33 & 148 & 1532 \\
\hline $\mathbf{2 0 0 5}$ & 19 & 97 & 874 \\
\hline $\mathbf{2 0 0 6}$ & 5 & 19 & 235 \\
\hline $\mathbf{2 0 0 7}$ & 5 & 19 & 235 \\
\hline $\mathbf{2 0 0 8}$ & 3 & 10 & 139 \\
\hline $\mathbf{2 0 0 9}$ & 3 & 10 & 139 \\
\hline $\mathbf{2 0 1 0}$ & 2 & 3 & 46 \\
\hline $\mathbf{2 0 1 1}$ & 2 & 3 & 46 \\
\hline
\end{tabular}

Kaynak: Kültür ve Turizm Bakanlığı, 2013.

Yatlardaki sayısal gerilemeye karșın ülkemize gelen yerli ve yabancı yatlardaki yolcu sayıları (Tablo 5) yıllar itibariyle artıș göstermektedir. Özellikle, son yıllarda yolcu sayısı 20 bini aşan rakamlara ulașılmıștır. Bu sonuç, turistik ziyaretler, yat çekek yerleri ve yat limanlarının kıșlaması vb. gerekçelerle ülkemiz kıyılarının önemli bir uğrak yeri olarak tercih edildiğinin bir göstergesi olarak alınabilir. 
Tablo 5:

Ülkemiz Limanlarına Yat ile Gelen Yolcu Sayıları

\begin{tabular}{|c|c|c|c|c|c|c|}
\hline \multirow[t]{2}{*}{ Yillar } & \multicolumn{3}{|c|}{ Yerli } & \multicolumn{3}{|c|}{ Yabancı } \\
\hline & Ticari & Özel & Toplam & Ticari & Özel & Toplam \\
\hline 1988 & 305 & 405 & 710 & 5268 & 9604 & 14872 \\
\hline 1989 & 287 & 337 & 624 & 5331 & 8495 & 13826 \\
\hline 1990 & 656 & 541 & 1197 & 5845 & 10770 & 16615 \\
\hline 1991 & 352 & 286 & 638 & 2828 & 5368 & 8196 \\
\hline 1992 & 439 & 186 & 625 & 6401 & 5515 & 11916 \\
\hline 1993 & 346 & 200 & 546 & 4622 & 6636 & 11258 \\
\hline 1994 & 195 & 128 & 323 & 5010 & 6825 & 11835 \\
\hline 1995 & 324 & 82 & 406 & 6165 & 5251 & 11416 \\
\hline 1996 & 432 & 227 & 659 & 6898 & 7287 & 14185 \\
\hline 1997 & 480 & 288 & 768 & 3481 & 7514 & 10995 \\
\hline 1998 & 572 & 314 & 886 & 6853 & 5980 & 12833 \\
\hline 1999 & 389 & 454 & 843 & 3142 & 5521 & 8663 \\
\hline 2000 & 536 & 226 & 762 & 4162 & 2466 & 6628 \\
\hline 2001 & 750 & 260 & 1010 & 5577 & 4300 & 9877 \\
\hline 2002 & 960 & 318 & 1278 & 7684 & 4894 & 12578 \\
\hline 2003 & 1048 & 513 & 1561 & 6836 & 2727 & 9563 \\
\hline 2004 & 1307 & 605 & 1912 & 9932 & 3528 & 13460 \\
\hline 2005 & 1511 & 675 & 2186 & 13574 & 3660 & 17234 \\
\hline 2006 & 1859 & 1152 & 3011 & 16649 & 5984 & 22633 \\
\hline 2007 & 2155 & 2159 & 4314 & 15456 & 10627 & 26083 \\
\hline 2008 & 2065 & 1821 & 3886 & 18984 & 6340 & 25324 \\
\hline 2009 & 2467 & 3746 & 6213 & 15104 & 9419 & 24523 \\
\hline 2010 & 2152 & 3480 & 5632 & 11386 & 10025 & 21411 \\
\hline 2011 & 2797 & 4666 & 7463 & 12042 & 8780 & 20822 \\
\hline
\end{tabular}

Kaynak: Kültür ve Turizm Bakanlığı, 2013.

Yıllar itibariye yerli ve yabancı yatlarda çalıșan personel sayısına bakıldığında (Tablo 6) son yıllarda bir artış gösterdiği dikkat çekmektedir. Yat ve çalıșan sayısındaki bu artışlar dikkate alındığında yatçılık ve yat ișletmeciliği çalıșma alanının giderek ivme kazandığı söylenebilir. 
Tablo 6:

Ülkemiz Limanlarına Gelen Yatların Mürettebat Sayıları

\begin{tabular}{|c|c|c|c|c|c|c|}
\hline \multirow[t]{2}{*}{ Yillar } & \multicolumn{3}{|c|}{ Yerli } & \multicolumn{3}{|c|}{ Yabancı } \\
\hline & Ticari & Özel & Toplam & Ticari & Özel & Toplam \\
\hline 1988 & 997 & 371 & 1368 & 1525 & 2524 & 4049 \\
\hline 1989 & 1063 & 316 & 1379 & 1621 & 1762 & 3383 \\
\hline 1990 & 2100 & 728 & 2828 & 1038 & 3099 & 4137 \\
\hline 1991 & 1126 & 285 & 1411 & 411 & 1540 & 1951 \\
\hline 1992 & 1643 & 74 & 1717 & 1447 & 729 & 2176 \\
\hline 1993 & 1043 & 67 & 1110 & 1219 & 745 & 1964 \\
\hline 1994 & 1248 & 117 & 1365 & 1214 & 664 & 1878 \\
\hline 1995 & 1466 & 41 & 1507 & 1468 & 463 & 1931 \\
\hline 1996 & 1947 & 104 & 2051 & 1115 & 354 & 1469 \\
\hline 1997 & 1631 & 205 & 1836 & 675 & 1350 & 2025 \\
\hline 1998 & 3220 & 252 & 3472 & 501 & 974 & 1475 \\
\hline 1999 & 1280 & 31 & 1311 & 831 & 81 & 912 \\
\hline 2000 & 1502 & 130 & 1632 & 195 & 1141 & 1336 \\
\hline 2001 & 2190 & 219 & 2409 & 600 & 3665 & 4265 \\
\hline 2002 & 3014 & 288 & 3302 & 330 & 2641 & 2971 \\
\hline 2003 & 3688 & 1251 & 4939 & 2473 & 8277 & 10750 \\
\hline 2004 & 4709 & 1048 & 5757 & 886 & 7162 & 8048 \\
\hline 2005 & 5667 & 1563 & 7230 & 1259 & 7421 & 8680 \\
\hline 2006 & 6130 & 2414 & 8544 & 2825 & 8506 & 11331 \\
\hline 2007 & 6453 & 5122 & 11575 & 2771 & 10562 & 13333 \\
\hline 2008 & 7170 & 3242 & 10412 & 838 & 9023 & 9861 \\
\hline 2009 & 6365 & 4614 & 10979 & 2093 & 10840 & 12933 \\
\hline 2010 & 5597 & 4148 & 9745 & 635 & 7438 & 8073 \\
\hline 2011 & 6541 & 5241 & 11782 & 686 & 7961 & 8647 \\
\hline
\end{tabular}

Kaynak: Kültür ve Turizm Bakanlığı, 2013.

İtalya'nın 6.500 km. uzunluğundaki kıyılarında 380, İspanya'nın 4.964 km uzunluğundaki kıyılarında 96, Hırvatistan'ın 5.835 km uzunluğundaki kıyılarında 50 adet marina varken, her yönü ile çok daha güzel, değișik, zengin 8333 kilometrelik kıyılarımızda ise sadece 46 adet marina bulunmaktadır (Tablo 7) (DT0, 2010: 132).

Tablo 7 incelendiğinde yat limanlarının Bodrum, Göcek, Didim, Kuşadası ve Fethiye kıyılarında yoğunlaștığı görülür. Bunu İstanbul ve Antalya illeri takip etmektedir. 
Tablo 7:

Kültür ve Turizm Bakanlığı’ndan Belgeli Deniz Turizmi Tesisleri

\begin{tabular}{|c|c|c|c|c|}
\hline \multirow[t]{2}{*}{ Liman Adı } & \multirow[t]{2}{*}{ Türü } & \multirow[t]{2}{*}{ Bulunduğu İt } & \multicolumn{2}{|c|}{ Kapasite } \\
\hline & & & Denizde & Karada \\
\hline 1. Setur Kușadası Yat Limanı & Ana Yat Limanı & Kușadası / AYDIN & 310 & - \\
\hline 2. Ataköy Yat Limanı & Tali Yat Limanı & Ataköy / ISTANBUL & 700 & 40 \\
\hline 3. Akdeniz Kemer Marinası & Tali Yat Limanı & Kemer / ANTALYA & 150 & 150 \\
\hline 4. Kaleiçi Yat Limanı & Yat Yanașma Yeri & Kaleiçi / ANTALYA & 90 & - \\
\hline 5. Altınyunus Yat Limanı & Tali Yat Limanı & Çeșme / IZMIR & 90 & 60 \\
\hline 6. Amiral Fahri Korutürk Yat Limanı & Tali Yat Limanı & Fenerbahçe / ISTANBUL & 558 & - \\
\hline 7. Marmaris Yat Limanı & Ana Yat Limanı & Marmaris / MUĞLA & 676 & 122 \\
\hline 8. Club Marina & Yat Yanașma Yeri & Göcek / MUĞLA & 121 & - \\
\hline 9. Celebi Marina & Tali Yat Limanı & ANTALYA & 200 & 150 \\
\hline 10. Ayvalık Marina & Tali Yat Limanı & Ayvalık / BALIKESIR & 100 & - \\
\hline 11. Kumlubükü Yat Club & Yat Yanașma Yeri & Marmaris / MUĞLA & 10 & - \\
\hline 12. Turgutreis Yat Limanı & Ana Yat Limanı & Turgutreis/MUĞLA & 455 & 100 \\
\hline 13. Ece Marina & Yat Yanașma Yeri & Fethiye/MUĞLA & 230 & - \\
\hline 14. Milta Bodrum & Tali Yat Limanı & Bodrum/MUĞLA & 348 & 50 \\
\hline 15. My Marina & Yat Yanașma Yeri & Marmaris/MUĞLA & 48 & 15 \\
\hline 16. D-Marin Didim & Ana Yat Limanı & Didim/AYDIN & 619 & 650 \\
\hline 17. Port Göcek Marina & 3 çıpalı Yat limanı & Fethiye/Muğla & 379 & - \\
\hline TOPLAM & & & 5084 & 1337 \\
\hline GENEL TOPLAM & & & 64 & \\
\hline
\end{tabular}

Kaynak: Kültür ve Turizm Bakanlığı, 2013.

Tablo 8' da görüldüğü gibi turistik amaçlarla hizmet veren yat limanları da yine Ege bölgesinde toplanmıștır. Burada sadece yeni bir yat alanı olarak Kocaeli Gebze dikkat çekmektedir.

Tablo 8:

Turizm İșletmesi Belgeli Yat Çekek Yerleri

\begin{tabular}{|l|c|c|c|c|}
\hline Liman Adı & Türü & Bulunduğu İ & \multicolumn{2}{c|}{ Kapasite } \\
\hline & & & Denizde & Karada \\
\hline 1-Atabay Turizm Yat Çekek Yeri & Yat Çekek Yeri & Gebze / KOCAELI & - & 60 \\
\hline 2-Ayvalık Yat Çekek Yeri & Yat Çekek Yeri & Ayvalık/ BALIKESIR & - & 140 \\
\hline 3-Albatros Yat Çekek Yeri & Yat Çekek Yeri & Marmaris / MUĞLA & 40 & 48 \\
\hline 4-Yat Lift & Yat Çekek Yeri & Bodrum/ MUĞLA & - & 400 \\
\hline
\end{tabular}




\begin{tabular}{|l|c|c|c|c|}
\hline 5-Ağanlar Yat Çekek Yeri & Yat Çekek Yeri & Bodrum/ MUĞLA & - & 200 \\
\hline 6-Göcek Yat Çekek Yeri & Yat Çekek Yeri & Fethiye/ MUĞLA & - & 156 \\
\hline TOPLAM & & & 40 & 1004 \\
\hline GENEL TOPLAM & & & 1044 \\
\hline
\end{tabular}

Kaynak: Kültür ve Turizm Bakanlığı, 2013.

Tablo 9' da yatırım belgeli olarak hizmet veren ișletmeye açılacak olan yat ișletmelerinin de Muğla ili kıyılarında, İstanbul'da ve Antalya'da olduğu görülür. Bu sonuçlara göre ülkemizdeki yatçılık ve marinacılıkta en gelișmiș yörenin bașta Ege bölgesi olduğu, bunu İstanbul ve Antalya'nın izlediği söylenebilir.

Tablo 9:

Turizm Yatırımı Belgeli Yat Limanları

\begin{tabular}{|c|c|c|c|c|}
\hline \multirow[t]{2}{*}{ Liman Adı } & \multirow[t]{2}{*}{ Türü } & \multirow[t]{2}{*}{ Bulunduğu ìl } & \multicolumn{2}{|c|}{ Kapasite } \\
\hline & & & Denizde & Karada \\
\hline 1-Alacatur Turistik Tesisleri Yat Limanı & Tali Yat Limanı & Turgutreis / MUĞLA & 40 & 12 \\
\hline 2-Meersea Körmen Yat Limanı & Tali Yat Limanı & Datça / MUĞLA & 246 & 56 \\
\hline 3-Martı Marina ve Yat İșletmeleri A.\$̦. & Tali Yat Limanı & Marmaris / MUĞLA & 301 & 70 \\
\hline 4-Kalkedon Marina & Tali Yat Limanı & Bodrum / MUĞLA & 200 & 200 \\
\hline 5-Bodrum Yalıkavak Yat Limanı & Ana Yat Limanı & Bodrum / MUĞLA & 336 & 100 \\
\hline 6-Alaçatı Yat Limanı & Ana Yat Limanı & Çeșme/IZMiR & 260 & 250 \\
\hline 7-Ataport Yat Limanı & Ana Yat Limanı & Zeytinburnu/ISTANBUL & 1000 & 100 \\
\hline 8-Alanya Yat Limanı & Ana Yat Limanı & Alanya/ANTALYA & 287 & 160 \\
\hline 9-Marintürk Exclusive Göcek & Yat Yanașma Yeri & Göcek-Fethiye/MUĞLA & 96 & - \\
\hline 10-Marintürk Göcek Village Port & Tali Yat Limanı & Göcek-Fethiye/MUĞLA & 116 & 200 \\
\hline 11-Mandalya Yat Yanașma Yeri & Yat Yanașma Yeri & Milas/MUĞLA & 50 & - \\
\hline 12-Çeșme Yat Limanı & Ana Yat Limanı & Çeșme/IZMiR & 377 & 100 \\
\hline 13-Burhaniye Yat Limanı & Tali Yat Limanı & Burhaniye/BALIKESIR & 210 & 100 \\
\hline 14-Yalova Yat Limanı & Ana Yat Limanı & YALOVA & 240 & 80 \\
\hline 15-Sığacık Yat Limanı & 5 Çıpalı Yat Limanı & Seferihisar/IZMIR & 400 & 80 \\
\hline 16-Skopea Marina & Rıhtım/İskele & Göcek/MUĞLA & 80 & - \\
\hline TOPLAM & & & 4239 & 1508 \\
\hline GENEL TOPLAM & & & \multicolumn{2}{|c|}{5747} \\
\hline
\end{tabular}




\section{b. Yat ve Marina İșletmelerinin İstihdam Değerlendirmesi}

Tablo 6'daki verilere bilgilere dayanarak ülkemizde yerli ticari ve özel yatlarda ortalama beș personel çalıșmakta olduğu, yolcu bașına yaklașık 1,5 personel düștüğü belirlenmiștir. Yıllar itibariyle yolcu sayısındaki artıș nitelikli personel ihtiyacını da arttırmaktadır. Ülkemiz yat limanlarına 2001 yılı itibariyle yerli ve yabancı yatlar ile yaklaşık 30 bin yolcu gelmiștir.

Yat turizminin sağladığı istihdam olanaklarının hesaplamak için, bir yatın üretiminden bașlayarak denizde veya karada geçirdiği süreler boyunca aldığı hizmetlerin ayrıntılı olarak değerlendirilmesi gerekmektedir.

Özellikle turizm amaçlı kullanılan yatların, istihdam gerektiren süreleri aşağıdaki biçimde sınıflandırılabilir (T.C. Ulaștırma Bakanlığı, 2010: 389). Bunlar;

- Yat üretim süreleri: Yatların üretilmeleri için geçen zamandır.

- Marinada bekleme süresi:

- Marina hizmetleri: Marinaların hizmetlerini gerçekleștirmek üzere yararlandığı personel istihdamı

- Mürettebat hizmetleri: Yatların denizde yanașma yerinde beklerken geçirdikleri zamandır

- Seyir süreleri; yatların seyir sırasında (liman dıșında denizde iken) geçirdikleri zamandır.

- Bakım süreleri; yatların bakım için çekek yerinde geçirdikleri zamandır.

Yatların ahșap, fiber, kompozit ya da alüminyum ${ }^{(2)}$ olması, büyüklüklerinin değișiklik göstermesi nedeni ile yukarıda verilen dört ayrı zamandaki hizmet gereksinimleri ve istihdam yaratma durumları da farklıdır. Bunu ayrıntılandırmak için öncelikle yatları kategorilere ayırmak gereklidir. Bu çalıșmada üç ayrı yat kategorisi düșünülerek yaratılabilecek istihdam hesaplanmaya çalıșılmıștır. Bu kategoriler așağıdaki gibidir:

1. Kategori A: 15 metre uzunluktan daha küçük olan yatlar: Bu yatlar ülkemizdeki toplam yat sayısının \%66'sını olușturmaktadır.

2. Kategori B: 15 ile 25 metre arası uzunlukta olan: Bu yatlar ülkemizdeki toplam yat sayısının \%24'ünü olușturmaktadır.

3. Kategori C: 25 metre uzunluktan daha büyük olan: Bu yatlar ülkemizdeki toplam yat sayısının \%10'unu olușturmaktadır.

Yat turizmi istihdamı hesaplanırken yatın imalatı için gerekli istihdam hesaplamalara

2 http://akasiayachting.com/tr/yat-imalati/ Erișim tarihi 16 Haziran 2013. 
dâhil edilmemiștir. Ülkemizde bir marinada her 10 yat için ortalama bir marina görevlisi istihdam edildiği varsayılmaktadır. Bu rakam ülkedeki 24 marina üzerinde yapılan bir araștırma ile marina, yat ve personel sayıları alınarak belirlenmiștir. Yatların marinalarda bekleme zamanında gerekli olan istihdam yat marinada beklerken yatın içinde görev yapan maaşlı personeli ifade etmektedir ki bunlar da kaptan ve tayfa sayısıdır. Fakat A Kategorisindeki yatlar marinada beklerken yat içinde görevli bulundurmazken, B kategorisindeki yatlarda en az bir kaptan ve genellikle bir tayfa bulundurulmalıdır. C kategorisindeki yatlarda ise bir kaptan ve en az bir tayfa zorunludur (T.C. Ulaștırma Bakanlığı, 2010: 390).

Yatların seyri esnasında tüm kategorilerde kaptan ve yat personeli zorunludur. Yatların seyir süreleri değișkenlik göstermesine karșın Kategori A için yılda 12 hafta, Kategori $B$ için yılda 10 hafta ve Kategori $C$ için ise yılda 8 hafta seyir süresi kabul edilmektedir. Kategori A tipi yatların seyri için seyir süresince yat bașına ortalama 0.5 istihdam, Kategori B tipi yatlarda 3 ve Kategori C tipi yatlarda ise yat bașına ortalama 4 istihdam öngörülmektedir.

Yatların bakım sırasında gerekli olan istihdama bakılacak olursa yatın ortalama bakım süresi dikkate alınmalıdır. Kategori A tipi yatların normal bakımı için ortalama 1.5 hafta ve 3 bakım elemanı, Kategori B tipi yatların normal bakımı için ortalama 2.5 hafta ve 5 bakım elemanı gerektiği varsayılabilir. Bu iki kategori yatların ahșap veya fiber olmasının hizmet süreleri ve ihtiyaç duyulan bakım elemanı sayısını değiștireceği de dikkate alınarak ortalama değerler varsayılmaktadır. Kategori C tipi yatların ise normal bakım için ortalama 4 hafta ve 8 bakım elemanına ihtiyaç duyacağı kabul edilebilir.

Master planda (2010) bu veriler kullanılarak yapılan hesaplar Tablo 10'da görülmektedir. Buna göre ülkemizde yat sayısında yaklașık 35,000 adet artıș olması ve bunların da Kategori A, B ve C arasındaki dağılımı sırası ile \%66, \%24 ve \%10 olarak düșünüldüğünde istihdam artıșının yaklașık 37,000 kiși olabileceği öngörülebilir. Ülke içindeki yat üretimi sayısının, denize indirilecek yeni yatların toplam sayısındaki payı tam olarak tahmin edilemeyeceğinden, Tablo 10' da verilen toplam istihdam hesapları içinde yat üretiminde gerekli olan istihdam yoktur. 
Tablo 10:

Yat Turizmi İstihdam Hesapları

\begin{tabular}{|c|c|c|c|c|c|c|}
\hline Kategori & Yüzde & $\begin{array}{c}\text { Artan Yat } \\
\text { Sayısı }\end{array}$ & $\begin{array}{c}\text { Marina } \\
\text { Hizmetleri } \\
\text { istihdam/yat }\end{array}$ & $\begin{array}{c}\text { Marina } \\
\text { hizmetleri } \\
\text { İstihdam/ } \\
\text { toplam yat }\end{array}$ & $\begin{array}{c}\text { Marinalarda } \\
\text { Bekleme } \\
\text { (hafta/yat/ } \\
\text { yil) }\end{array}$ & İstihdam/Yıl \\
\hline $\mathrm{A}$ & 66 & 23,100 & 0.1 & 2, & 52 & 2,310 \\
\hline B & 24 & 8,400 & 0.1 & 8 & 52 & 84 \\
\hline \multirow[t]{2}{*}{ C } & 10 & 3,500 & 0.1 & 3 & 52 & 35 \\
\hline & & & & & Toplam & 3,500 \\
\hline Kategori & Yüzde & $\begin{array}{c}\text { Artan Yat } \\
\text { Sayısı }\end{array}$ & $\begin{array}{l}\text { Marinalarda } \\
\text { Bekleme } \\
\text { istihdam/yat }\end{array}$ & $\begin{array}{c}\text { Marinalarda } \\
\text { bekleme } \\
\text { istihdam/ } \\
\text { toplam yat }\end{array}$ & $\begin{array}{c}\text { Marinalarda } \\
\text { bekleme } \\
\text { (hafta/yat/yıl) }\end{array}$ & İstihdam/yıl \\
\hline A & 66 & 23,100 & 0 & 0 & 40 & 0 \\
\hline B & 24 & 8,400 & 1.5 & 12 & 42 & 10177 \\
\hline \multirow[t]{2}{*}{ C } & 10 & 3,500 & 2.5 & 8, & 44 & 740 \\
\hline & & & & & Toplam & 17581 \\
\hline Kategori & Yüzde & $\begin{array}{l}\text { Artan Yat } \\
\text { Sayısı }\end{array}$ & $\begin{array}{l}\text { Seyir Halinde } \\
\text { istihdam/yat }\end{array}$ & $\begin{array}{l}\text { Seyir halinde } \\
\text { istihdam/ } \\
\text { toplam yat }\end{array}$ & $\begin{array}{l}\text { Seyir halinde } \\
\text { (hafta/yat/yıl) }\end{array}$ & İstihdam/Yıl \\
\hline A & 66 & 23,100 & 0.5 & 11, & 12 & 2,665 \\
\hline B & 24 & 8,400 & 3 & 25, & 10 & 4,846 \\
\hline \multirow[t]{2}{*}{$\mathrm{C}$} & 10 & 3,500 & 4 & 14 & 8 & 2,154 \\
\hline & & & & & Toplam & 9,665 \\
\hline Kategori & Yüzde & $\begin{array}{l}\text { Artan Yat } \\
\text { Sayısı }\end{array}$ & $\begin{array}{c}\text { Bakım } \\
\text { Yerlerinde } \\
\text { istihdam/yat }\end{array}$ & $\begin{array}{l}\text { Bakım } \\
\text { Yerlerinde } \\
\text { istihdam/ } \\
\text { toplam yat }\end{array}$ & $\begin{array}{c}\text { Bakım } \\
\text { Yerlerinde } \\
\text { (hafta/yat/yıl) }\end{array}$ & İstihdam/Yıl \\
\hline A & 66 & 23,100 & 3 & 69, & 1.5 & 1,999 \\
\hline $\mathrm{B}$ & 24 & 8,400 & 5 & 42 & 2.5 & 2,019 \\
\hline \multirow[t]{3}{*}{ C } & 10 & 3,500 & 8 & 28 & 4 & 2,154 \\
\hline & & & & & Toplam & 6,172 \\
\hline & & & & & $\begin{array}{l}\text { Genel } \\
\text { Toplam* }\end{array}$ & 36,918 \\
\hline
\end{tabular}

* Marina yapımı ve yat imalatı için gereken istihdam hariç Kaynak: T.C. Ulaștırma Bakanlığı, 2010.

Deniz Turizmi Yönetmeliği'nin 18. Maddesine göre, yat ișletmecileri 1618 sayılı Seyahat Acentaları ve Seyahat Acentaları Birliği Kanunu kapsamında Seyahat acentalarına münhasır faaliyetlerde bulunamazlar. Ancak yat ișletmeleri yatçıları geliș noktalarından alıp, varıs noktalarına bırakabilirler. Mürettebat olarak adlandırılan yat personeli ile ilgili bir organizasyon șemasına Şekil 1'de yer verilmektedir. 
Sekil 3:

Yat ișletmelerine İlișkin Örnek Organizasyon \$̣eması

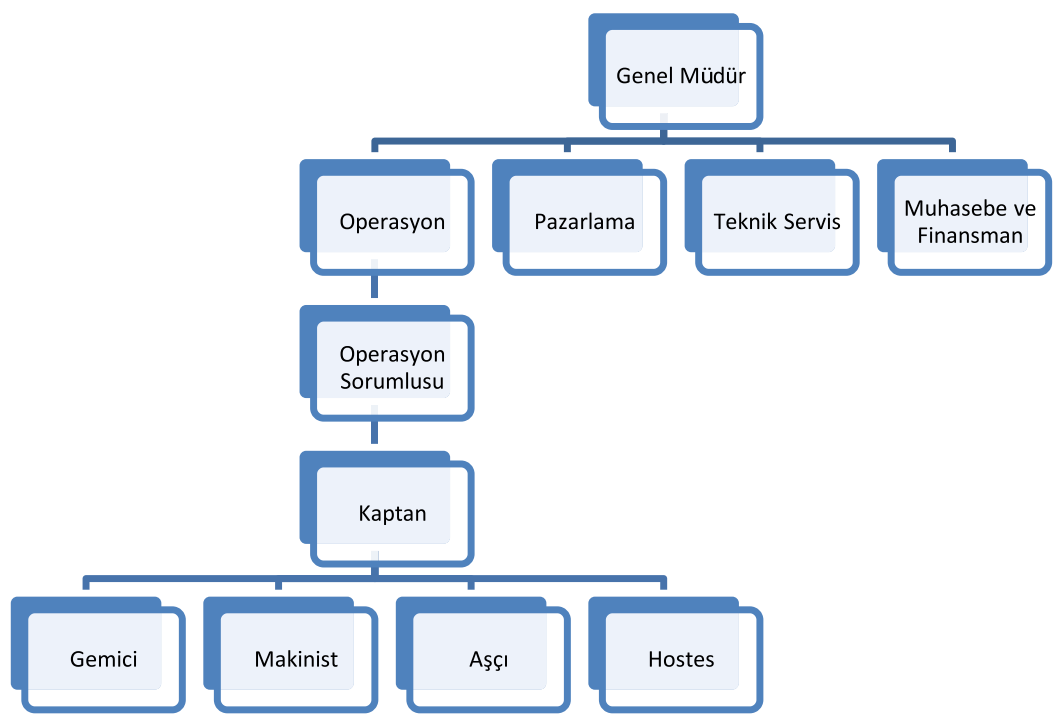

Kaynak: Hassan Tunç v.d., 2010: s.354.

Semada yer alan personelin Meslek Standartları Komisyonu tarafından yapılan görev tanımları ise şöyledir:

- Yat Kaptanı; tekneyi seyrüsefere hazırlama, yolcu alma, limana yanașma, ayrılma, teknenin iç ve dıș temizliği ile bakım tutum ișlemlerini yaptırma bilgi ve becerisine sahip nitelikli kiși,

- Gemici; tekne, yat ve geminin her türlü temizliğini yapan kiși,

- Makinist; Yatın makine bölümüne bakan ehliyetli, mekanik bilgisi ve elektronik bilgilerine sahip personeldir.

- Aşç; otel, lokanta, hastane, gemi, yolcu treni ve kamuya açık yiyecek yenilen diğer yerlerde, öğünleri planlayan, yemekleri hazırlayan ve pișiren, mutfaktaki çalıșmaları organize eden kiși,

- Hostes; seyahatlerde hizmet veren elemanlar.

Yat ișletmeleri, her ne kadar seyahat acentacılığı ișlemlerini yapamıyor olsa da farklı isimler adı altında ile bu hizmeti gerçekleștiren yat ișletmeleri bulunmaktadır. Yatçılık sektöründe mürettebatsız yat kiralayan yat ișletmeleri, yatlara handling ve lojistik hizmet veren işletmeler, mega yatlar kiralayan ve yat turları düzenleyen yat acentaları faaliyet göstermektedir. Hizmet çeșitliliğine bakıldığında, bu alanda yatlarda ve çekek yerlerinde (marinalarda) çalıșacak hizmet elemanı yanında, deniz turları konusunda yetișmiş elemana da ihtiyaç olduğu görülmektedir. 
Son 20 yıl içerisinde modern marinacılık hizmetlerinin yaygınlașması ile ülkemizin kıyı bandında bulunan yerleșim merkezlerinde yat limanı yatırımları çoğalmıș ve mevcut balıkçı barınakları bile yat limanı haline getirilmeye çalıșılmıștır. Yatların kıșlamaya alındıkları, bakım ve onarımlarının yapıldığı yat çekek yerleri, marina ișletmecileri için önemli bir gelir kaynağıdır. Yat limanlarının kara alanlarında da çekek yerleri bulunduğu gibi, yatlara sadece çekek, bakım ve onarım hizmeti sunan bağımsız tesisler de mevcuttur. Çekek yerlerinde bakım, onarım ve karaya çekme hizmeti verildiği için teknik personel istihdam edilmektedir. Yat yanașma yerlerinde ise bakım ve onarım hizmetlerinin yanında yat ile yolculuk yapanlara yeme içme, alıș veriş gibi hizmetler de verildiği için servis elemanları da istihdam edilir. Bir marinadaki organizasyon yapısına Șekil 2'de yer verilmektedir.

Sekil 4:

Bir Marinanın Organizasyon Yapısının Șeması

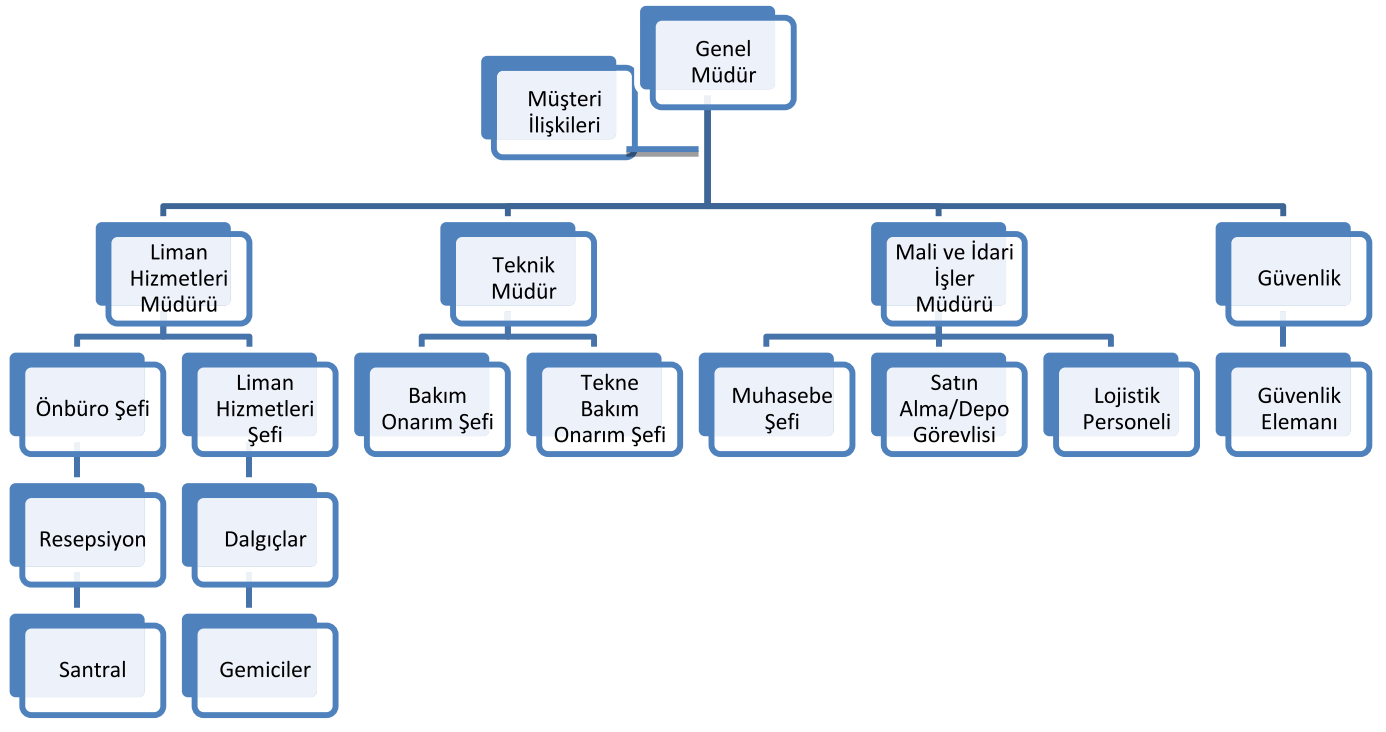

Kaynak: Hassan Tunç v.d., 2010: 368.

Yatlarda çalıștığı halde yatçılıkla doğrudan ilgili olmayan diğer personel ise ilgili alan şöyle sıralanabilir:

- Muhasebe Elemanı

- Kasa Elemanı

- Soför

- Personel Elemanı

- Servis Elemanı 
- Tesisatçı

- Marangoz

- Lift Operatörü

- Tekne elektrik

- Teknik Tașeronlar

- Bahçevan

- Temizlik Tașeronu olarak sayılabilir.

Bir bașka çalıșmada (Demirkol vd., 2002: 23) bir marinada çalıșan personeli așağıdaki gibi belirlenmiștir:

- Genel Müdür

- Marina Müdürü

- Personel Müdürü

- Satıs ve Pazarlama

- Mali ve İdari İșler

- Güvenlik

- Teknik Servisi

- Liman Hizmetleri

- Temizlik

- Önbüro

- Muhasebe

- Marina Sorumlu Kaptanı

- Market

- Sosyal ve İdari İșler

\section{Bulgular ve Değerlendirme}

Marinalar, yat turizmiyle hareket eden turistlere her türlü tur hizmetin yanı sıra yiyecek ve içecek temin eden, restoran hizmeti veren, yatın bakım ve onarımının yapıldığı merkezlerdir. Yat ve marinacılık sektöründe kaliteli elaman istihdam etmek, ișgücü düzeyinin karșılığı ücret vermek, profesyonel așçı ve kaptan istihdam etmek, tekneleri belirli standartta tutmak, marinaların uluslararası standartlarda fiziksel özelliklere kavușturulması gibi sorunlar yașanmaktadır (Yarcan, 1993: 87).

Yat-Marina ișletmeleri, sunduğu hizmetler itibarı lyata ilișkin bakım-onarım hizmeti, yatçıya servis, önbüro hizmetleri, konaklama hizmetleri vs.) ile aynı personelde çeșitli yeterlilikleri bir arada gerektirmektedir. Bu bağlamda bu sektörde çalışacak olan personelde bazı asgari nitelikleri taşıması gerekmektedir. Söz konusu bu nitelikleri genel olarak șöyle sıralamak mümkündür (Demirkol vd., 2002: 20-21); 
- Yata hizmet veren yönetici ve çalıșan konumundaki kișinin, denizcilik bilgisine ve Gemi Adamı ${ }^{(3)}$ ehliyetine sahip olması yanında, bu kișilerin bakım ve onarımdan sorumlu olmaları durumunda, motor, yat inșa, yelken, elektronik, fiber, metal ve ahșap boya bilgilerine de sahip olmaları gerekir.

- Yatçılara hizmet veren çalıșanlar ise ön büro, mutfak, servis, muhasebe, temizlik vb. tüm turizm hizmetleri ile ilgili mesleki bilgi ve beceriye sahip olması yanında, yatçılarla daha iyi diyalog kurabilmesi için deniz konusunda da bilgili olması gerekir. Ancak bu grup personelde Gemi Adamı olma koșulu aranmamaktadır.

Bu meslekte gerekli olan bilgi ve becerilerin yanı sıra; müșteri memnuniyeti, dış görünüș, temizlik, iletișim, ayrıca yabancı konușma düzeyinde yabancı dil bilmek gibi özelliklere ihtiyaç duyulmaktadır.

Turizmin çeșitlendirilmesi ve yat turizminde görünen gelișmeler ve Türkiye'nin Akdeniz havzasındaki en fazla mavi bayraklı kıyılara sahip ülke imajına sahip olması, Türk yat turizminin hızla gelișmesine neden olmuștur. 2011 yılında 23 milyar dolar olan turizm gelirinin yaklaşık 4 milyar doları, kapasitesinin sadece \%10'u kullanılan yat turizminden elde edilmektedir. Yat turizmi ve buna bağlı olarak yat ve marina işletmeciliği sektörünün gelișimi de ülke ekonomisi için büyük önem tașımaktadır. Bu sektör hizmet yoğun bir sektördür ve kalifiye elemana ihtiyaç duyulmaktadır. Sektörün her geçen gün artan bu ihtiyacına bağlı olarak, yat turizminde görev alacak personelin eğitimi konusu bazı eğitim kurumları tarafından tartıșılmaya bașlanmıștır. Türkiye'de yat turizminde çalıșacak personelin eğitiminde denizcilik ve ulaștırma sektöründe hizmet veren farklı eğitim kurumlarından yararlanılmaktadır bu kurumlar șunlardır (Kozak, 1999: 52): Çeșitli yat ve yatçılık dernekleri tarafından açılan kısa dönemli kurslar, denizcilik gemi inșaatı liseleri, denizcilik yüksekokulları ve son yıllarda açılan denizcilik fakülteleridir.

Ülkemiz kıyılarında 2002 yılı sonu itibariyle 25 adet marina varken, 2011 yılında bu sayı 46'ya çıkmıș ve bu süreçte marina sayısında \%94'lük bir artıș olmuștur. Bu artış özellikle sektörün işgücü ihtiyacını da gündeme getirmiștir. Fakat bu sektörde; önbüro bölümünde çalıșanların turizm alanında eğitim veren üniversitelerden mezun öğrenciler olduğu, gemici olarak çalıșmak üzere denizcilik ve su sporlarında yetișmiș elemanların tercih edildiği, idari kadronun ise çekirdekten yetiștiği belirtilmiștir. Dolayısı ile istihdama yönelik ciddi bir sorunun yașanmadığı vurgulanmıștır. Bunun yanında marina yatırımları ve yat trafiğinde beklenen artışa karșı günümüzdeki istihdam stratejilerinin yeterli olmayacağı görüșü hâkimdir. Ayrıca bu alanda mezun veren okullardan mezunların da marinalarda çalıșmadığı vurgulanmıștır. Yine marina ve yat sektöründe uygulanan düșük ücret politikası nedeniyle ara elemanların niteliklerinin de düșük olduğu, üniversite mezunları tarafından tercih edilmediği, personel devir oranının yüksek olduğu be-

3 Geminin kaptanına, zabitlerine, yardımcı zabitlerine, stajyerlerine, tayfalarına ve yardımcı hizmet personeline gemi adamı denir. 
lirtilmektedir. Marinalarda en çok teknik șef ve yetișmiş elektrik teknisyeni bulma konusunda sorun yașanabildiği, özellikle teknik șef pozisyonu için gemi inșaat bölümlerinin ideal yeterlilik olduğu, çekek personelinin ise alt kadrolardan yetiștirilerek sağlandığı da belirtilen bir diğer unsurdur.

Sayısal verilerin aksine, istihdam sorunu yok gibi algılansa da bunun niceliksel anlamda olduğunu söylemek mümkündür. Diğer taraftan marinalarda hizmet kalitesinin arttırılabilmesi için, mevcut personelin eğitimi ya da eğitimli personelin istihdam edilmesi zorunluluğu kaçınılmaz olacaktır.

\section{A. Yat ve Marina İșletmeciliği Eğitimi}

Ülkemizde yatçılık ve yat güzergâhları konularında, marina ișletmeciliği konusunda gerekli bilgi ve donanıma sahip personel yetiștirmek üzere eğitim veren ön lisans programları Marina İșletmeciliği; Yat İșletme ve Yönetimi olarak adlandırılmıștır. Bu programlarda marinalara, denizcilik ișletmelerine, brokerlik șirketlerine, limanlara, gemi inșa tesislerine șu elemanların yetiștirilmesi amaçlanmaktadır;

- Yönetici yardımcısı,

- Türk veya yabancı bayraklı özel ve ticari yatlara yat kaptanı,

- Deniz ve denizcilikle ilgili tüm sektörlere danıșman ve uzman personel,

- İdari personel,

- Yat kaptanı,

- Yat servis elamanları,

- Marinalarda çalıșacak büro elamanlarını ve teknik personel.

Türkiye'de denizcilik öğretiminin dört yıllık lisans programlarında gerçekleștirildiği 10 yüksekokul bulunmaktadır (Ölçme, Seçme ve Yerleștirme Merkezi, 2012). Bu okullar lojistik, ulaștırma, mühendislik ve ișletme yönetimi alanlarında lisans eğitimi vermekte ve deniz ticaret filosuna zabit, deniz ticaret filosunun yönetim, destek ve acenta hizmetlerini yerine getirecek personel yetiștirmektedir. Denizcilik Fakültesi, Deniz Ulaștırma ve İșletme Mühendisliği, Gemi Makineleri İșletme Mühendisliği gibi isimlerle kurulan bu okullardan denizcilik sektörünün farklı alanlarında çalıșacak nitelikli personel mezun olmaktadır. Denizcilik Fakülteleri, deniz ticaret filolarında çalıșacak üst düzey gemi adamlarını ve denizcilik ile ilgili sektörde görev alacak kalifiye yöneticiler yetiștirirken, Deniz Ulaștırma ve İșletme Mühendisliği bölümü mezunları, ticari denizcilik, güverte zabitliği ve uzak yol kaptanlığı yapmaktadırlar. Gemi Makineleri İșletme Mühendisliği bölümünde ise uzak yol gemilerinde bașmühendis yetiștirilmektedir.

Türkiye'de dört yıllık lisans eğitimi veren Denizcilik Okulları ve Fakülteleriyle ilgili bilgilere aşağıda yer verilmektedir (Ölçme, Seçme ve Yerleștirme Merkezi, 2012). 
Denizcilik Fakülteleri ve Yüksekokulları

- Zirve Üniversitesi Deniz Ulaștırma İșletme Mühendisliği

- Dokuz Eylül Üniversitesi-Denizcilik Fakültesi

- İstanbul Teknik Üniversitesi-Denizcilik Fakültesi

- İstanbul Üniversitesi-Mühendislik Fakültesi

- Karadeniz Teknik Üniversitesi-Sürmene Deniz Bilimleri Fakültesi

- Kocaeli Üniversitesi-Barbaros Denizcilik Yüksekokulu

- Piri Reis Üniversitesi-Denizcilik Yüksek Okulu

- Rize Üniversitesi-Turgut Kıran Denizcilik Yüksekokulu

- Yakın Doğu Üniversitesi-Denizcilik Fakültesi

- Yıldız Teknik Üniversitesi-Makine Fakültesi

- Zonguldak Karaelmas Üniversitesi-Deniz ișletmeciliği ve Yönetimi Yüksekokulu

Ülkemizde denizcilik sektöründe özellikle ara eleman açığını kapatacak personelin yetișmesine yönelik önlisans programları șunlardır;

- Sınırlı Vardiya Zabiti yetiștiren Deniz ve Liman İșletmeciliği programı

- Vardiya Zabiti yetiștiren Deniz Ulaștırma ve İșletme Programı

- Makine Zabiti yetiștiren Gemi Makineleri İșletme Programı

- Yat turizm ișletmelerinde çalıșacak yat kaptanı, idari personel, yat servis elemanı ve marinada çalıșacak büro elemanı yetiștiren Yat İșletme ve Yönetimi programı

- Yatlarda kaptan, marinalarda ve denizcilik ișletmelerinde, brokerlik șirketlerinde, gemi inșa tesislerinde çalıșacak yönetici yardımcısı ve büro elemanı yetiștiren Marina İșletme programı.

Türkiye'de bu eğitimi veren yükseköğretim kurumları ile ilgili bilgilere așağıda yer verilmiștir.

\section{Denizcilik Meslek Yüksekokulları}

1. Bahçeșehir Üniversitesi-Meslek Yüksekokulu (Deniz ve Liman İșletmeciliği)

2. Beykoz Lojistik Meslek Yüksekokulu (Marina İșletme ve Deniz ve Liman İsletmeciliği)

3. Çanakkale Üniversitesi-Gelibolu Piri Reis Meslek Yüksekokulu (Deniz ve Liman İșletmeciliği)

4. Dokuz Eylül Üniversitesi-Seferihisar Fevziye Hepkon Sosyal Bilimler Meslek Yüksek Okulu (Marina İșletme)

5. Galatasaray Üniversitesi-Meslek Yüksekokulu (Gemi Makineleri İșletme ve Deniz Ulaștırma ve İșletme)

6. İstanbul Teknik Üniversitesi-Meslek Yüksekokulu (Gemi Makineleri İşletme ve Deniz Ulaștırma ve İșletme)

7. Kocaeli Üniversitesi-Karamürsel Meslek Yüksekokulu (Deniz ve Liman İșletmeciliği ve Gemi Makineleri İsletme) 
8. Mersin Üniversitesi-Deniz ve Ticaret Meslek Yüksekokulu (Deniz Ulaștırma ve İșletme, Deniz ve Liman İșletmeciliği ve Gemi Makineleri İșletme)

9. Ordu Üniversitesi-Fatsa Meslek Yüksekokulu (Gemi Makineleri İșletme ve Deniz Ulaștırma ve İșletme)

10. Uludağ Üniversitesi-Gemlik Asım Kocabıyık Meslek Yüksekokulu (Deniz ve Liman İșletmeciliğil

11. Yakın Doğu Üniversitesi -Denizcilik Meslek Yüksekokulu (Deniz Ulaștırma ve İșletme, Deniz ve Liman İșletmeciliği ve Gemi Makineleri İșletme)

12. Yalova Üniversitesi-Yalova Meslek Yüksekokulu (Yat İșletme ve Yönetimi ve Deniz ve Liman İșletmeciliğil

13. Zonguldak Karaelmas Üniversitesi -Alaplı Meslek Yüksekokulu (Gemi Makineleri İsletme)

14. Mustafa Kemal Üniversitesi-Pirinçlik Meslek Yüksekokulu (Deniz ve Liman İșletmeciliğil

\section{Sonuç ve Öneriler}

Görüldüğü üzere ülkemizde yat ve marinacılık sektöründe çalıșmak üzere ara eleman yetiștiren sadece üç okul ve bölüm bulunmaktadır. Marina ișletme programlarının öğrenci kontenjanı yaklașık 30 kișidir. Yat İsletme ve Yönetimi Bölümünün kontenjanı ise 40 kișidir. Ülkemizde üniversitelerin dıșında yat ve marinacılık sektörüne ara eleman yetiștirmek üzere özel sektör ve kamu tarafından açılan çeșitli kurslar da bulunmaktadır. Milli Eğitim Bakanlığı tarafından Halk Eğitim Merkezlerinde Marina İsletmeciliği Kursu, Yat Hizmet Elemanı Yetiștirme Kursu ve Özel sektör tarafından İleri Seviye Yatçılık kursları verilmektedir.

Bu çalıșma göstermektedir ki sayısı az olarak görülen eğitim kurumlarından mezunların yat ve marina ișletmelerinde çalıșma oranı düșüktür. Bu nedenle öncelikle mevcut okulların sektör ile ișbirliği kaçınılmazdır.

Pek çok yeni marina yatırımının yapılıyor olması, bu alanda eğitimli ve nitelikli personel eksikliği ve bu alanda çalıșan ara elemanlarda mesleki olarak standartlaşmanın olmaması, yat ve marina ișletmeciliği alanında eğitim verecek önlisans programlarının gerekliliğini doğurmaktadır. Dolayısı ile yüksek eğitim kurumlarının ilgili programları açarak sektörde duyulan nitelikli ara eleman açığına destek olmaları önerilmektedir. Ayrıca hâlihazırda yat ve marina ișletmelerinde çalıșan alaylı olarak tanımlanan eğitimi olmayan personelin hem çalıșma hayatlarına devam edip diğer yandan eğitimlerini sürdürebilmeleri için açık öğretim sisteminde bu programlar önerilmektedir.

Bu programlarda, yat ve marinalarda çalıșacak, yat işletmelerinde çalıșacak idari personel, yat servis elamanları, marinalarda çalıșacak büro elamanlarını yetiștirilmelidir. 


\section{KAYNAKÇA}

Ahipașaoğlu, Halit Suavi ve İrfan Arıkan (2005) Seyahat Işletmeleri Yönetimi ve Ulaștırma Sistemleri, Ankara: Detay.

Akoğlan Kozak, Meryem (1999) “Türkiye'de Yat Turizmi Eğitimi”; TUGEV Seçme Makaleleriçinde, 49, Temmuz.

Anonim (2013) http://akasiayachting.com/tr/yat-imalati Erișim tarihi 16 Haziran 2013.

Arlı, Erdal (2012) “Yat Limanı İșletmeciliğinde Hizmet Kalitesi Faktörlerinin Tekrar Tercih Etme Niyeti, Tavsiye Etme Niyeti ve Genel Memnuniyet Düzeyi Üzerindeki Etkisi”, Anatolia: Turizm Araștırmaları Dergisi, 23 (1), s.19-32.

Demirkol, Sehnaz, Elbeyi Pelit ve Gonca Kılıç (2010) “Yat, Kruvaziyer ve Marina İsletmelerinde Kalite Yönetimi”, Turizm Işletmelerinde Toplam Kalite Yönetimi içinde (der. S. Demirkol ve M. Halis), İstanbul: Değișim.

Demirkol, Șehnaz, Elbeyi Pelit ve Gonca Kılıç (2002) “Yat-Marina İșletmelerindeki Yönetici ve İşörren Sorunları Üzerine Bir Alan Araștırması”, Turizm Akademik Dergisi, 1, s.13-32.

Deniz Ticaret Odası (2010) “2010 Deniz Sektörü Raporu”, İstanbul.

Deniz Ticaret Odası (2012) http://www.denizticaretodasi.org/ Erișim tarihi 18 Kasım 2012.

Eriș, Engin Deniz (2007) "Uluslararası Pazarlarda Türk Marinalarının Cekiciliği Ve Pazarlama Stratejileri"; Ege Akademik Bakıș/Ege Academic Review, 7 (1), s.37-55.

Kültür ve Turizm Bakanlığı (2012) Deniz Turizmi Yönetmeliği, http://teftis.kulturturizm. gov.tr/TR,14610/deniz-turizmi-yonetmeligi.html Erișim tarihi 20 Kasım 2012.

Olgaç, Serkan (2001) Türkiye'deki Yat Limanlarından Elde Edilen Gelirlerin Türkiye Turizmine Katkısı. Basılmamıș Yüksek Lisans Tezi, Eskișehir: Anadolu Üniversitesi Sosyal Bilimler Enstitüsü.

Ölçme, Seçme ve Yerleștirme Merkezi (2012) http://dokuman.osym.gov.tr/pdfdokuman/ 2012/OSYS/20120SYSKONTKILAVUZ.pdf Erișim tarihi 23 Aralık 2012.

T.C. Ulaștırma Bakanlığı (2010) Turizm Kıyı Yapıları Master Plan Çalıșması Sonuç Raporu. Ankara: Yüksel Proje Uluslararası A.S. ve Belde Proje ve Danıșmanlık Tic. Ltd. Ști. Yarcan, Şükrü (1993) Seyahat Yönetimi, İstanbul: Boğaziçi Üniversitesi Meslek Yüksekokulu Turizm Programı Yayını.

Yüksek, Gökçe (2010) “Yat Turizmi”, Turizm Ulaștırmasıiçinde (der. İ. Arıkan), Eskișehir: Anadolu Üniversitesi Yayın No: 2131, Açıköğretim Fakültesi Yayın No:1159. 


\title{
FİZİKSEL AKTİVİTE VE SAĞLIKLI BESLENMENİN BİLİŞİM SEKTÖRÜNDE MASA BAŞINDA ÇALIŞANLARIN SAĞLIĞINA ETKİLERİNİN DEĞERLEMESİ (1)
}

BURCU GÜVEN (2)

\begin{abstract}
öz
Bu çalıșmada son yıllarda ișyeri koșullarının değișimi ve sağlığı koruma yerine geliștirme ile birlikte ortaya çıkan fiziksel aktivite ve sağlıklı beslenme hizmetleri ele alınmıştır. Bu kapsamda bilișim sektöründe masa bașında çalıșanlara yönelik fiziksel aktivite ve sağlıklı beslenme bağlamında yönetsel faaliyetlerin bilișim sektöründe masa bașında çalıșanların sağlığına etkisi araștırılmıștır. Araștırmanın uygulama alanı İstanbul bölgesinde yer alan bilișim sektöründeki büyük ölçekli ișletmelerdir.
\end{abstract}

Araștırmanın sonucunda elde edilen veriler faktör analizine tabi tutulmuș, ișyeri ortamı ve yönetsel faaliyetlerle ilgili olan faktörler ile çalıșan sağlığı arasında korelasyon ve çoklu regresyon analizleri yapılmıștır. İșyeri sağlık iklimi, ișyeri sağlık kültürü ve çalışanların yönlendirilmesiyle ilgili olan bu değișkenler ile bulgular yorumlanmıștır.

Anahtar Kelimeler: Fiziksel aktivite, İșyeri sağlık iklimi, İşyeri sağlık kültürü, Masa başında çalıșanlar, Sağlıklı beslenme

JEL Kodları: M12

\section{ABSTRACT}

In the research with the changes occurred in the working conditions, the perception of the concept of health phsyical activity and healthy nutrition are studied within the context of employee health promotion services. In the methodological part of the research, the effects of physcial activity and healthy nutrition on sedentary workers' health have been assessed in information technology sector.

1 Bu makale 10-12 Mayıs 2012 tarihinde gerçekleșen 11.Ulusal İșletmecilik Kongresi'nde sunulan “Fiziksel Aktivite ve Sağlıklı Beslenmenin Masa Bașında Çalıșanların Sağlığına Etkilerinin Değerlemesi ve Bilișim Sektörüne Yönelik Bir Uygulama” bașlıklı tebliğin geliștirilmiș halidir.

2 Öğr. Gör. Dr., Beykoz Lojistik Meslek Yüksekokulu, burcuguvenabeykoz.edu.tr 
The data obtained from the research are first analysed with the help of factor analysis. In addition, the findings of the factor analysis related to worksite health climate, managerial activities and their effects on the employee health are analysed with corelation and multiple regression analysis methods. These variables and findings regarding worksite health climate, worksite health culture and the coordination of the employee in the services are interpreted.

Keywords: Healthy nutrition, physical activity, sedentary workers, worksite health climate, worksite health culture

JEL Codes: M12 


\section{Giriș}

Gelișmiş ülkelerin ekonomik güçlerinin kaynağı sanayi devrimi dönemlerinde endüstriye dayanırken günümüzde bilgiye sahip olan ülkeler bir adım önde olmaktadır. Bu değișimlere bağlı olarak gelișmiș ülkelerde öne çıkan sektörlerin hizmet üreten, bilgi kullanımı ağırlıklı, bilișim sektörünün de içinde yer aldığı üçüncül sektörler olduğu görülmektedir (Mütercimler, 2006: 67). Ekonomide görülen bu değișimler, çalıșma koșullarının değișimine neden olarak bedensel emeğin kullanımından ziyade zihinsel emeğin kullanımına neden olmaktadır. İsyerleri yașanan bu değișimler ile birlikte fabrikadan ofise dönüșmekte, çalıșanlar mesai saatleri süresince ofislerde masa bașında, bilgisayar karșısında minimum hareket, maksimum zihin emeği ile çalıșmaktadırlar.

Çalıșanlar yalnızca çalıșma hayatında hareketsizlik ile karşı karşıya kalmamakta, gündelik hayatta teknolojik dönüșümler ile gelen yenilikler de hareketsizliği arttırmaktadır. Gelișen teknolojinin yanı sıra zaman sıkıntısı, büyük șehirlerdeki yașam biçimlerinin getirdiği değișiklikler beslenme alıșkanlıklarını değiștirmektedir. Yașam biçimlerindeki değișimlerin etkilediği bir diğer konu ise ölüm nedenleridir. Türkiye'de ölümlerin en önemli nedeni kalp-damar rahatsızlıklarıdır. Kalp-damar rahatsızlıklarının ardından kanser gelmektedir (Sağlık Bakanlığı, 2010: 20). Bu rahatsızlıkları hareketsizlik ve sağlıksız beslenme doğrudan etkilemektedir. Bu değișimlerin yanı sıra sağlık kavramının tanımı ile ilgili gerçekleșen dönüșümler, sağlığın korunması yerine geliștirilmesi yönündeki bakıș açısının yerleșmesi, sağlıklı olmanın üst sınırının olmaması fiziksel aktivite (FA) ve sağlıklı beslenme (SB) gibi sağlığı geliștirici hizmetleri ortaya çıkarmıștır. Günümüzde ișletmelerin çalıșan sağlığı ile ilgili olușturdukları politikaları düzenlerken bu faktörleri dikkate almaları gerekmektedir.

Türkiye' de 2010 yılından itibaren Sağlık Bakanlığı ve çeșitli ilaç firmalarının, derneklerin ve vakıfların yürüttükleri kampanyalar ile toplum, sağlıklı beslenme ve fiziksel aktivite konusunda bilinçlendirilmeye çalıșılmaktadır. Türkiye'nin gelișmiș ülkelerle ekonomik anlamda yarıșabilmesi, onlarla aynı platformlarda yer alabilmesi ve toplumun refahı için yalnızca sosyal güvenlik sistemlerindeki değișimlerin yeterli olmayacağı daha pratik çözümlere de gereksinim duyulduğunun FA ve SB hizmetlerinin uygulamaları ile anlasılması gerekmektedir.

\section{Araștırma}

Araștırmada, 5 adet ana ve 2 adet demografik hipotez toplanan veriler ve kullanılan analiz yöntemleri ile test edilmiștir. 


\subsection{Araștırmanın Modeli}

Araștırmada bağımlı değișkenler ve bağımsız değișken arasındaki değerlendirmeyi yapabilmek amacıyla așağıdaki hipotezler olușturulmuștur.

\section{Araștırmanın Hipotezleri}

$\mathrm{H}_{1}$ : İşyeri ortamının sağlıklı beslenme ve fiziksel aktivite için uygunluğu ile çalıșan sağlığı arasında ilișki vardır.

$\mathrm{H}_{2}$ : İșletmenin sağlıklı beslenmeye verdiği önem ve yönlendirme ile çalıșan sağlığı arasında ilișki vardır.

$\mathrm{H}_{3}$ : İșletmenin fiziksel aktiviteye verdiği önem ve yönlendirme ile çalıșan sağlığı arasında ilișki vardır.

$\mathrm{H}_{4}$ : İșletme çalıșanlarının fiziksel aktiviteye verdiği önem ve yönlendirme ile çalıșan sağlığı arasında ilișki vardır.

$\mathrm{H}_{5}$ : İșletme çalıșanlarının sağlıklı beslenmeye verdiği önem ve yönlendirme ile çalıșan sağlığı arasında ilișki vardır.

\section{Demografik Özellikler ile Ilgili Hipotezler}

$\mathrm{H}_{6}$ : Cinsiyet ile sağlık durumu arasında ilișki vardır.

$\mathrm{H}_{7}$ : Çalıșanların medeni durumu ile sağlık durumları arasında ilișki vardır.

Araștırma kapsamında belirlenen hipotezlere bağlı olarak “İşyeri Ortamının Sağlıklı Beslenme ve Fiziksel Aktivite İçin Uygunluğu”, “İșlemenin Fiziksel Aktiviteye Verdiği Önem ve Yönlendirme”, “İșletmenin Sağlıklı Beslenmeye Verdiği Önem ve Yönlendirme”, “İșletme Çalıșanlarının Fiziksel Aktiviteye Verdikleri Önem”, “İșletme Calıșanlarının Sağlıklı Beslenmeye Verdiği Önem”, incelenmiș ve her bir boyutun çalıșanların sağlığı üzerindeki görece etkisi karșılaștırmalı olarak sorgulanmıștır. Araștırmada belirlenen hipotezleri test edebilmek için iki ölçeğe bașvurulmuștur. Araștırmanın ölçeklerinden biri Mazzola'nun 2010 yılında geliștirdiği “İşyeri Fiziksel Aktivite Ve Beslenme İklimi” ölçeğidir (Mazzola, 2010: 90-5). Bu ölçekte kullanılan Likert ölçeği 1'den 5'e kadar , “Hiç Katılmıyorum”, “Kısmen Katılıyorum”, “Orta Düzeyde Katılıyorum”, “Büyük Ölçüde Katılıyorum”, “Tümüyle Katılıyorum” ifadelerini içermektedir.

Araștırmada kullanılan diğer ölçek ise Hege R. Eriksen, Camilla Ihlebak ve Holger Ursin tarafından geliștirilen “Sübjektif Sağlık Șikâyetleri” ölçeğidir. 28 farklı sağlık șikâyetinin yer aldığı ölçekte çalıșanlardan her bir sağlık problemini son bir ayda yașama durumlarını, hangi șiddette yașadıklarını ve söz konusu problemin ne kadar sürdüğünü belirtmeleri istenmiștir ( Eriksen vd. , 2002: 20-9). Hastalığın șiddetinin ölçülmesinde “Hiç”, “Hafif Düzeyde”, “Orta” ve “Ciddi” olmak üzere dörtlü Likert ölçeğinden yararlanılmıștır. 
Ölçeklerin yabancı dilden çevrilmesinden ve geçerlilik ile ilgili yașanabilecek olan sıkıntıları giderebilmek adına iki ölçekte tüm sorular kullanılmıș, soruların çevirisi yapılırken çeviri biliminden bir uzman, bir Türk dili ve edebiyatı uzmanı ile ișletme bilimi uzmanlarının görüșlerine bașvurulmuștur.

\subsection{Araștırmanın Amacı}

Araștırmanın amacı, bilișim sektöründeki ișletmelerde FA ve SB’ye yönelik hizmetler ile ilgili yürütülen yönetsel faaliyetlerin çalıșan sağlığına etkilerini ortaya koymaktır. Uygulamada kullanılan ölçeklerde, çalıșanların FA ve SB'ye yönlendirilmesinin, ișletmenin hizmetlere verdiği önemin ve ișyerinde hizmetler için uygun çevresel koșullar olușturulmasının çalıșan sağlığına etkilerinin değerlemesi araștırılmaktadır.

\subsection{Anakütle ve Örneklem}

Bilișim sektöründe yer alan ișletme çalıșanları araștırmanın hedef kitlesini olușturmaktadır. TÜlK verilerine göre ülkemizdeki büyük ölçekli ișletmelerde 3,5 milyon kiși çalıșmaktadır. 2008 yılında TÜIKK tarafından yayınlanan raporda girișimlerin faaliyet sınıflandırılması verilmiștir. Söz konusu olan bilișim sektöründeki ișletmeler, sınıflandırmada “I- Ulaștırma, Depolama ve Haberleșme Faaliyetleri” içerisinde yer almakta ve söz konusu sınıflandırmanın toplam faaliyet alanları içerisindeki payı \%16,9'dur. Bu hesaba göre yaklașık olarak 591.000 kiși bu faaliyet alanında çalıșmaktadır.

Bu evren çerçevesinde ve basit rastlantısal örneklem türüne bağlı olarak anket soruları araștırmanın yapıldığı ișletmelerde tesadüfî olarak belirlenen 600 çalıșana uygulanmıs ve 450 anket geri dönüșü gerçekleșmiș, bu anketlerden 401'i geçerli kabul edilmiștir. Bu örneklem türünde çalıșanların birbirine kıyasla eșit seçilme durumu söz konusudur (Erdoğan, 2007: 171). Sonuç olarak araștırma bulgularının \%95 güven aralığında, $\pm \% 5$ örnekleme hatası ile genellenebileceği söylenebilmektedir (Türker, 2006: 47)

\subsection{Verilerin Analizi}

Araștırmada veri toplama araçları ile elde edilen bilgilerin çözümlenmesi SPSS 18 paket programı kullanılarak bilgisayar ortamında gerçekleștirilmiștir. Anketin güvenilirliğinin test edilmesinde Alfa Katsayısından (Cronbach Alfa) yararlanılmıștır. Yapılan analizlerde 401 katılımcıdan elde edilen veriler kullanılmıștır. Ayrıca soruların, alfa katsayısına ne derecede ve ne yönde etkide bulunduklarını saptayabilmek için; “Değișken Silindiği Takdirde Ölçeğin Alfa Katsayısı” (Alpha if Item Deleted) değeri hesaplanmıștır. Söz konusu değerler, herhangi bir değișken silindiği takdirde, geri kalan değișkenlerin iç tutarlılıklarını göstermektedir. 
Bu çerçevede ișyerinde sağlıklı beslenme ve fiziksel aktivite iklimi ölçeği anketinin güvenilirliğinin incelenmesi sonrasında $a=0,937$ gibi yüksek bir güvenilirlik değeri elde edilmiștir.

Tablo 1:

Güvenilirlik Değeri

\begin{tabular}{|c|c|}
\hline Cronbach's Alpha & Madde Sayısı \\
\hline, 937 & 23 \\
\hline
\end{tabular}

Tablo 2'de ise sübjektif sağlık șikâyetleri ölçeğinin güvenilirlik değerleri gösterilmiștir.

Tablo 2:

Sübjektif Sağlık Șikâyetleri Ölçeği Güvenilirlik Değeri

\begin{tabular}{|c|c|}
\hline Cronbach's Alpha & Madde Sayısı \\
\hline, 891 & 28 \\
\hline
\end{tabular}

Ölçeğin faktör yapısının belirlenmesinde faktör analizi yönteminden yararlanılmıștır. Varyans analizi tablosundaki verilerden ölçeğin 5 faktörden oluștuğu anlașılmaktadır. Ayrıca varyans değerleri incelendiğinde ölçeği olușturan 5 faktörün toplam varyansın \%65'ini açıkladığı görülmektedir. Sonuçlar Tablo 3'de gösterilmektedir.

Tablo 3:

Toplam Varyans

\begin{tabular}{|c|c|c|c|c|c|c|}
\hline \multirow{2}{*}{ Bileșen } & \multicolumn{3}{|c|}{ Bașlangıç Değerleri } & \multicolumn{3}{|c|}{ Yönlendirilmiş Yüklemeler Toplamı } \\
\hline & Top. & $\%$ Var. & Top. $\%$ & Top. & $\%$ Var. & Top. \% \\
\hline 1 & 9,955 & 43,285 & 43,285 & 3,877 & 16,857 & 16,857 \\
\hline 2 & 1,595 & 6,936 & 50,221 & 3,509 & 15,255 & 32,112 \\
\hline 3 & 1,255 & 5,455 & 55,677 & 3,218 & 13,993 & 46,104 \\
\hline 4 & 1,171 & 5,090 & 60,767 & 3,137 & 13,640 & 59,744 \\
\hline 5 & 1,055 & 4,588 & 65,355 & 1,291 & 5,611 & 65,355 \\
\hline 6 & ,884 & 3,842 & 69,196 & & & \\
\hline 7 & ,790 & 3,436 & 72,632 & & & \\
\hline 8 & ,733 & 3,187 & 75,819 & & & \\
\hline 9 &, 634 & 2,755 & 78,574 & & & \\
\hline 10 &, 533 & 2,318 & 80,892 & & & \\
\hline 11 &, 525 & 2,284 & 83,176 & & & \\
\hline 12 & ,484 & 2,105 & 85,281 & & & \\
\hline
\end{tabular}




\begin{tabular}{|l|l|l|l|l|l|l|}
\hline $\mathbf{1 3}$ &, 437 & 1,901 & 87,182 & & & \\
\hline $\mathbf{1 4}$ &, 427 & 1,854 & 89,036 & & & \\
\hline $\mathbf{1 5}$ &, 401 & 1,742 & 90,778 & & & \\
\hline $\mathbf{1 6}$ &, 365 & 1,588 & 92,365 & & & \\
\hline $\mathbf{1 7}$ &, 338 & 1,469 & 93,834 & & & \\
\hline $\mathbf{1 8}$ &, 298 & 1,294 & 95,128 & & & \\
\hline $\mathbf{1 9}$ &, 273 & 1,186 & 96,315 & & & \\
\hline $\mathbf{2 0}$ &, 259 & 1,127 & 97,442 & & & \\
\hline $\mathbf{2 1}$ &, 226 &, 982 & 98,424 & & & \\
\hline $\mathbf{2 2}$ &, 190 &, 827 & 99,250 & & & \\
\hline $\mathbf{2 3}$ &, 172 &, 750 & 100,000 & & & \\
\hline
\end{tabular}

Tablo 4'de gösterilen temel bileșenler analizi sonrasında elde edilen bileșen matrisinde de ölçeğin 5 faktörden oluștuğu anlașılmakla birlikte, belirgin bir faktör yapısı elde edilememiștir. Bu nedenle her bir faktörün yüklemelerini daha net olarak görerek faktörler arası karșılaștırmaya imkân vermek amacıyla elde edilen 5 faktörlük sonuç yönlendirmeye tabii tutulmuștur. Bu amaçla Varimax yönlendirme metodu kullanılmıștır. Sonuçlar Tablo 4'de gösterilmektedir.

Tablo 4:

Temel Bileșenler Matrisi

\begin{tabular}{|c|c|c|c|c|c|}
\hline & \multicolumn{5}{|c|}{ Bileșen } \\
\hline & 1 & 2 & 3 & 4 & 5 \\
\hline 1. Șirketim çalıșanlarının egzersiz yapmasına önem verir. & ,659 & & & & \\
\hline $\begin{array}{l}\text { 2. Șirketim çalışanlarının sağlıklı beslenmesine önem } \\
\text { verir. }\end{array}$ &, 680 & & & & \\
\hline $\begin{array}{l}\text { 3. Şirket çalıșanlarına sağlıklı besinler yeterli ölçüde } \\
\text { tanıtılmaktadır. }\end{array}$ &, 732 & & & & \\
\hline $\begin{array}{l}\text { 4. Șirket çalıșanlarına uygun egzersiz alıșkanlıkları yeterli } \\
\text { ölçüde anlatılmaktadır. }\end{array}$ &, 731 & & & & \\
\hline $\begin{array}{l}\text { 5. Șirket çalıșanları sağlıklı beslenmeye büyük önem } \\
\text { vermektedirler. }\end{array}$ &, 718 & & & & \\
\hline $\begin{array}{l}\text { 6. Șirket çalıșanları düzgün egzersiz yapmaya büyük önem } \\
\text { vermektedirler. }\end{array}$ &, 701 & & & & \\
\hline $\begin{array}{l}\text { 7. Sirket çalıșanları birbirlerinin egzersiz alıșkanlıklarını } \\
\text { desteklerler. }\end{array}$ & .706 & & & & \\
\hline $\begin{array}{l}\text { 8. Șirketteki çalıșanların büyük bir kısmı fiziksel olarak } \\
\text { formdadır. }\end{array}$ & 674 & & & & \\
\hline 9. Șirket çalıșanları sağlıklı beslenmeye teșvik edilirler. &, 780 & & & & \\
\hline
\end{tabular}




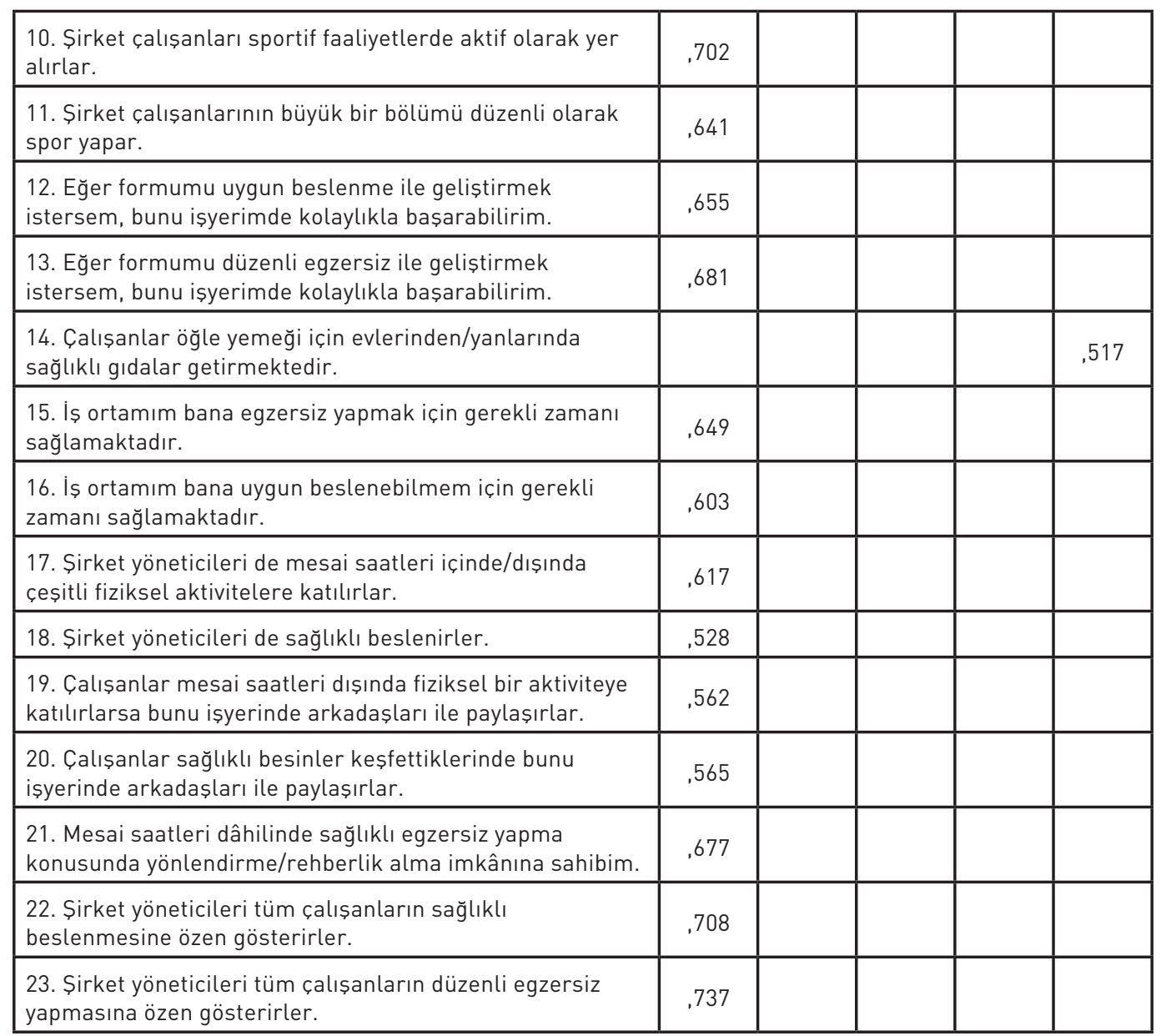

Tablo 4' de değerlerden “Çalıșanlar öğle yemeği için evlerinden/yanlarında sağlıklı gıdalar getirmektedir" maddesi ayrı bir faktör olarak yer almaktadır. Sağlıklı bir faktör yapısı için her bir faktör altında en az üç soru olması gerekliliği dikkate alınarak söz konusu madde ölçekten çıkartılmıș ve analiz tekrarlanmıștır (Stevens, 2009: 35). Tablo 5'te çıkarılan soru ile olușturulan yönlendirilmiș temel bileșenler matrisi ortaya konmuștur.

Tablo 5:

Yönlendirilmiș Temel Bileșenler Matrisi

\begin{tabular}{|l|c|c|c|c|c|}
\hline & \multicolumn{5}{|c|}{ Bileșen } \\
\hline & $\mathbf{1}$ & $\mathbf{2}$ & $\mathbf{3}$ & $\mathbf{4}$ & $\mathbf{5}$ \\
\hline 1. Șirketim çalıșanlarının egzersiz yapmasına önem verir. &, 635 & & & & \\
\hline $\begin{array}{l}\text { 2. Șirketim çalıșanlarının sağlıklı beslenmesine önem } \\
\text { verir. }\end{array}$ & & & & \multirow{5}{*}{, 582} & \\
\hline $\begin{array}{l}\text { 3. Șirket çalıșanlarına sağlıklı besinler yeterli ölçüde } \\
\text { tanıtılmaktadır. }\end{array}$ &, 543 & & &, 552 & \\
\hline
\end{tabular}




\begin{tabular}{|c|c|c|c|c|c|}
\hline $\begin{array}{l}\text { 4. Șirket çalıșanlarına uygun egzersiz alıșkanlıkları yeterli } \\
\text { ölçüde anlatılmaktadır. }\end{array}$ & ,707 & & & & \\
\hline $\begin{array}{l}\text { 5. Șirket çalıșanları sağlıklı beslenmeye büyük önem } \\
\text { vermektedirler. }\end{array}$ & & & &, 515 & \\
\hline $\begin{array}{l}\text { 6. Șirket çalıșanları düzgün egzersiz yapmaya büyük önem } \\
\text { vermektedirler. }\end{array}$ & 668 & & & & \\
\hline $\begin{array}{l}\text { 7. Șirket çalıșanları birbirlerinin egzersiz alıșkanlıklarını } \\
\text { desteklerler. }\end{array}$ &, 599 & & & & \\
\hline $\begin{array}{l}\text { 8. Șirketteki çalıșanların büyük bir kısmı fiziksel olarak } \\
\text { formdadır. }\end{array}$ & & &, 561 & & \\
\hline 9. Șirket çalıșanları sağlıklı beslenmeye teșvik edilirler. & & & &, 521 & \\
\hline $\begin{array}{l}\text { 10. Șirket çalıșanları sportif faaliyetlerde aktif olarak yer } \\
\text { alırlar. }\end{array}$ & & &, 516 & & \\
\hline $\begin{array}{l}\text { 11. Șirket çalıșanlarının büyük bir bölümü düzenli olarak } \\
\text { spor yapar. }\end{array}$ & & &, 552 & & \\
\hline $\begin{array}{l}\text { 12. Eğer formumu uygun beslenme ile geliștirmek } \\
\text { istersem, bunu ișyerimde kolaylıkla bașarabilirim. }\end{array}$ & & ,708 & & & \\
\hline $\begin{array}{l}\text { 13. Eğer formumu düzenli egzersiz ile geliștirmek } \\
\text { istersem, bunu ișyerimde kolaylıkla bașarabilirim. }\end{array}$ & &, 765 & & & \\
\hline $\begin{array}{l}\text { 14. Çalıșanlar öğle yemeği için evlerinden/yanlarında } \\
\text { sağlıklı gıdalar getirmektedir. }\end{array}$ & & & & & 811 \\
\hline $\begin{array}{l}\text { 15. İș ortamım bana egzersiz yapmak için gerekli zamanı } \\
\text { sağlamaktadır. }\end{array}$ & & ,779 & & & \\
\hline $\begin{array}{l}\text { 16. İș ortamım bana uygun beslenebilmem için gerekli } \\
\text { zamanı sağlamaktadır. }\end{array}$ & & ,654 & & & \\
\hline $\begin{array}{l}\text { 17. Şirket yöneticileri de mesai saatleri içinde/dıșında } \\
\text { çeșitli fiziksel aktivitelere katılırlar. }\end{array}$ & & & & & \\
\hline 18. Şirket yöneticileri de sağlıklı beslenirler. & & & & 680 & \\
\hline $\begin{array}{l}\text { 19. Çalıșanlar mesai saatleri dıșında fiziksel bir aktiviteye } \\
\text { katılırlarsa bunu ișyerinde arkadașları ile paylașırlar. }\end{array}$ & & & .766 & & \\
\hline $\begin{array}{l}\text { 20. Calıșanlar sağlıklı besinler keșfettiklerinde bunu } \\
\text { ișyerinde arkadașları ile paylașırlar. }\end{array}$ & & &, 707 & & \\
\hline $\begin{array}{l}\text { 21. Mesai saatleri dâhilinde sağlıklı egzersiz yapma } \\
\text { konusunda yönlendirme/rehberlik alma imkânına sahibim. }\end{array}$ & &, 572 & & & \\
\hline $\begin{array}{l}\text { 22. Șirket yöneticileri tüm çalıșanların sağlıklı } \\
\text { beslenmesine özen gösterirler. }\end{array}$ & & & &, 753 & \\
\hline $\begin{array}{l}\text { 23. Șirket yöneticileri tüm çalıșanların düzenli egzersiz } \\
\text { yapmasına özen gösterirler. }\end{array}$ & & & & ,532 & \\
\hline
\end{tabular}

Tekrarlanan analiz sonrasında varyans analizi tablosundaki verilerden ölçeğinin 4 faktöre düștüğü anlașılmaktadır. Ayrıca varyans değerleri incelendiğinde ölçeği olușturan 4 faktörün toplam varyansın \% 64'ünü açıkladığı görülmektedir. Sonuçlar Tablo 6'da yer almaktadır. 
Tablo 6:

Toplam Varyans-2

\begin{tabular}{|c|c|c|c|c|c|c|}
\hline \multirow{2}{*}{ Bileșen } & \multicolumn{3}{|c|}{ Bașlangıç Değerleri } & \multicolumn{3}{|c|}{ Yönlendirilmiș Yüklemeler Toplamı } \\
\hline & Top. & $\%$ Var. & Top. $\%$ & Top. & $\%$ Var. & Top. \% \\
\hline 1 & 9,565 & 45,547 & 45,547 & 3,900 & 18,570 & 18,570 \\
\hline 2 & 1,556 & 7,409 & 52,955 & 3,614 & 17,211 & 35,781 \\
\hline 3 & 1,221 & 5,815 & 58,770 & 3,546 & 16,886 & 52,667 \\
\hline 4 & 1,127 & 5,368 & 64,139 & 2,409 & 11,472 & 64,139 \\
\hline 5 & 870 & 4,144 & 68,283 & & & \\
\hline 6 &, 809 & 3,851 & 72,135 & & & \\
\hline 7 &, 742 & 3,535 & 75,669 & & & \\
\hline 8 &, 558 & 2,658 & 78,327 & & & \\
\hline 9 &, 544 & 2,591 & 80,918 & & & \\
\hline 10 &, 525 & 2,500 & 83,417 & & & \\
\hline 11 & ,483 & 2,298 & 85,716 & & & \\
\hline 12 &, 433 & 2,060 & 87,776 & & & \\
\hline 13 & .406 & 1,931 & 89,707 & & & \\
\hline 14 & .366 & 1,743 & 91,450 & & & \\
\hline 15 &, 343 & 1,634 & 93,084 & & & \\
\hline 16 & ,314 & 1,497 & 94,580 & & & \\
\hline 17 & ,278 & 1,323 & 95,903 & & & \\
\hline 18 &, 265 & 1,262 & 97,165 & & & \\
\hline 19 & ,228 & 1,084 & 98,249 & & & \\
\hline 20 & ,194 &, 926 & 99,175 & & & \\
\hline 21 & ,173 & ,825 & 100,000 & & & \\
\hline 22 & ,190 &, 827 & 99,250 & & & \\
\hline 23 & ,172 & ,750 & 100,000 & & & \\
\hline
\end{tabular}

Temel bileșenler analizi sonrasında elde edilen bileșen matrisinde de ölçeğin 4 faktörden oluștuğu anlașılmakla birlikte, belirgin bir faktör yapısı elde edilememiștir. Bu nedenle her bir faktörün yüklemelerini daha net olarak görerek faktörler arası karşılaștırmaya imkân vermek amacıyla elde edilen 4 faktörlük sonuç yönlendirmeye tabii tutulmuștur. Bu amaçla Varimax yönlendirme metodu kullanılmıștır. Sonuçlar Tablo 7'de yer almaktadır. 
Tablo 7:

Temel Bileșenler Matrisi-2

\begin{tabular}{|c|c|c|c|c|}
\hline & \multicolumn{4}{|c|}{ Bileșen } \\
\hline & 1 & 2 & 3 & 4 \\
\hline 1. Șirketim çalıșanlarının egzersiz yapmasına önem verir. & .668 & & & \\
\hline 2. Șirketim çalıșanlarının sağlıklı beslenmesine önem verir. & 691 & & & \\
\hline 3. Șirket çalıșanlarına sağlıklı besinler yeterli ölçüde tanıtılmaktadır. & .736 & & & \\
\hline $\begin{array}{l}\text { 4. Șirket çalıșanlarına uygun egzersiz alıșkanlıkları yeterli ölçüde } \\
\text { anlatılmaktadır. }\end{array}$ & ,732 & & & \\
\hline 5. Șirket çalıșanları sağlıklı beslenmeye büyük önem vermektedirler. &, 721 & & & \\
\hline $\begin{array}{l}\text { 6. Șirket çalıșanları düzgün egzersiz yapmaya büyük önem } \\
\text { vermektedirler. }\end{array}$ &, 704 & & & \\
\hline $\begin{array}{l}\text { 7. Șirket çalıșanları birbirlerinin egzersiz alıșkanlıklarını } \\
\text { desteklerler. }\end{array}$ & .709 & & & \\
\hline 8. Șirketteki çalıșanların büyük bir kısmı fiziksel olarak formdadır. & ,671 & & & \\
\hline 9. Șirket çalıșanları sağlıklı beslenmeye teșvik edilirler. & .785 & & & \\
\hline 10. Șirket çalıșanları sportif faaliyetlerde aktif olarak yer alırlar. & .699 & & & \\
\hline 11. Șirket çalıșanlarının büyük bir bölümü düzenli olarak spor yapar. & ,637 & & & \\
\hline $\begin{array}{l}\text { 12. Eğer formumu uygun beslenme ile geliștirmek istersem, bunu } \\
\text { ișyerimde kolaylıkla bașarabilirim. }\end{array}$ & 657 & & & \\
\hline $\begin{array}{l}\text { 13. Eğer formumu düzenli egzersiz ile geliștirmek istersem, bunu } \\
\text { ișyerimde kolaylıkla bașarabilirim. }\end{array}$ &, 686 & & & \\
\hline $\begin{array}{l}\text { 15. İș ortamım bana egzersiz yapmak için gerekli zamanı } \\
\text { sağlamaktadır. }\end{array}$ & ,647 & & & \\
\hline $\begin{array}{l}\text { 16. İș ortamım bana uygun beslenebilmem için gerekli zamanı } \\
\text { sağlamaktadır. }\end{array}$ & 605 & & & \\
\hline 18. Șirket yöneticileri de sağlıklı beslenirler. &, 518 & & & \\
\hline $\begin{array}{l}\text { 19. Çalıșanlar mesai saatleri dıșında fiziksel bir aktiviteye } \\
\text { katılırlarsa bunu ișyerinde arkadașları ile paylașırlar. }\end{array}$ &, 557 & & & \\
\hline $\begin{array}{l}\text { 20. Çalıșanlar sağlıklı besinler keșfettiklerinde bunu ișyerinde } \\
\text { arkadașları ile paylașırlar. }\end{array}$ & .566 & & & \\
\hline $\begin{array}{l}\text { 21. Mesai saatleri dâhilinde sağlıklı egzersiz yapma konusunda } \\
\text { yönlendirme/rehberlik alma imkânına sahibim. }\end{array}$ & .677 & & & \\
\hline $\begin{array}{l}\text { 22. Șirket yöneticileri tüm çalıșanların sağlıklı beslenmesine özen } \\
\text { gösterirler. }\end{array}$ & .709 & & & \\
\hline $\begin{array}{l}\text { 23. Sirket yöneticileri tüm çalıșanların düzenli egzersiz yapmasına } \\
\text { özen gösterirler. }\end{array}$ & .734 & & & \\
\hline
\end{tabular}

Varimax yöntemi kullanılarak yapılan yönlendirme sonucunda elde edilen faktör yapısı Tablo 8'de sunulmuștur. Tablodaki değerlerden “Çalıșanlar mesai saatleri dıșında fiziksel bir aktiviteye katılırlarsa bunu ișyerinde arkadașları ile paylașırlar", "CCalıșanlar 
sağlıklı besinler keșfettiklerinde bunu ișyerinde arkadaşları ile paylaşırlar" maddeleri ayrı bir faktör olarak yer almaktadır. Sağlıklı bir faktör yapısı için her bir faktör altında en az üç soru olması gerekliliği dikkate alınarak söz konusu madde ölçekten çıkartılmıs ve analiz tekrarlanmıștır (Stevens, 2009: 40).

Tablo 8:

Yönlendirilmiș Temel Bileșenler Matrisi-2

\begin{tabular}{|c|c|c|c|c|}
\hline & \multicolumn{4}{|c|}{ Bileșen } \\
\hline & 1 & 2 & 3 & 4 \\
\hline 1. Șirketim çalıșanlarının egzersiz yapmasına önem verir. & & &, 536 & \\
\hline 2. Șirketim çalıșanlarının sağlıklı beslenmesine önem verir. & & .662 & & \\
\hline 3. Șirket çalıșanlarına sağlıklı besinler yeterli ölçüde tanıtılmaktadır. & & .644 & & \\
\hline $\begin{array}{l}\text { 4. Șirket çalıșanlarına uygun egzersiz alıșkanlıkları yeterli ölçüde } \\
\text { anlatılmaktadır. }\end{array}$ & ,651 & & & \\
\hline 5. Șirket çalıșanları sağlıklı beslenmeye büyük önem vermektedirler. & &, 566 & & \\
\hline $\begin{array}{l}\text { 6. Șirket çalıșanları düzgün egzersiz yapmaya büyük önem } \\
\text { vermektedirler. }\end{array}$ &, 741 & & & \\
\hline $\begin{array}{l}\text { 7. Șirket çalıșanları birbirlerinin egzersiz alıșkanlıklarını } \\
\text { desteklerler. }\end{array}$ & ,682 & & & \\
\hline 8. Șirketteki çalıșanların büyük bir kısmı fiziksel olarak formdadır. &, 540 & & & \\
\hline 9. Șirket çalıșanları sağlıklı beslenmeye teșvik edilirler. & &, 587 & & \\
\hline 10. Şirket çalıșanları sportif faaliyetlerde aktif olarak yer alırlar. & ,609 & & & \\
\hline 11. Șirket çalıșanlarının büyük bir bölümü düzenli olarak spor yapar. &, 551 & & & \\
\hline $\begin{array}{l}\text { 12. Eğer formumu uygun beslenme ile geliștirmek istersem, bunu } \\
\text { ișyerimde kolaylıkla bașarabilirim. }\end{array}$ & & &, 710 & \\
\hline $\begin{array}{l}\text { 13. Eğer formumu düzenli egzersiz ile geliștirmek istersem, bunu } \\
\text { ișyerimde kolaylıkla bașarabilirim. }\end{array}$ & & &, 785 & \\
\hline $\begin{array}{l}\text { 15. İs ortamım bana egzersiz yapmak için gerekli zamanı } \\
\text { sağlamaktadır. }\end{array}$ & & & ,780 & \\
\hline $\begin{array}{l}\text { 16. İș ortamım bana uygun beslenebilmem için gerekli zamanı } \\
\text { sağlamaktadır. }\end{array}$ & & & ,642 & \\
\hline 18. Șirket yöneticileri de sağlıklı beslenirler. & &, 623 & & \\
\hline $\begin{array}{l}\text { 19. Çalıșanlar mesai saatleri dıșında fiziksel bir aktiviteye } \\
\text { katılırlarsa bunu ișyerinde arkadașları ile paylaşırlar. }\end{array}$ & & & &, 765 \\
\hline $\begin{array}{l}\text { 20. Çalıșanlar sağlıklı besinler keșfettiklerinde bunu ișyerinde } \\
\text { arkadașları ile paylașırlar. }\end{array}$ & & & & ,693 \\
\hline $\begin{array}{l}\text { 21. Mesai saatleri dâhilinde sağlıklı egzersiz yapma konusunda } \\
\text { yönlendirme/rehberlik alma imkânına sahibim. }\end{array}$ & & &, 582 & \\
\hline $\begin{array}{l}\text { 22. Șirket yöneticileri tüm çalıșanların sağlıklı beslenmesine özen } \\
\text { gösterirler. }\end{array}$ & &, 771 & & \\
\hline $\begin{array}{l}\text { 23. Șirket yöneticileri tüm çalıșanların düzenli egzersiz yapmasına } \\
\text { özen gösterirler. }\end{array}$ & &, 571 & & \\
\hline
\end{tabular}


Tekrarlanan analiz sonrasında Varyans Analizi tablosundaki verilerden ölçeğinin faktör sayısının değișmediği anlașılmaktadır. Ayrıca varyans değerleri incelendiğinde ölçeği olușturan 4 faktörün toplam varyansın \%66'sını açıkladığı görülmektedir. Dolayısıyla anketten 2 sorunun çıkartılması ölçeğin açıklama gücünü \%2 oranında arttırmıștır. Sonuçlar Tablo 9'da yer almaktadır.

Tablo 9:

Toplam Varyans-3

\begin{tabular}{|c|c|c|c|c|c|c|}
\hline \multirow{2}{*}{ Bilesen } & \multicolumn{3}{|c|}{ Bașlangıç Değerleri } & \multicolumn{3}{|c|}{ Yönlendirilmiș Yüklemeler Toplamı } \\
\hline & Top. & $\%$ Var. & Top. \% & Top. & $\%$ Var. & Top. $\%$ \\
\hline 1 & 9,005 & 47,397 & 47,397 & 3,397 & 17,876 & 17,876 \\
\hline 2 & 1,447 & 7,617 & 55,014 & 3,216 & 16,924 & 34,800 \\
\hline 3 & 1,132 & 5,960 & 60,974 & 3,133 & 16,491 & 51,291 \\
\hline 4 & 1,025 & 5,394 & 66,369 & 2,865 & 15,077 & 66,369 \\
\hline 5 &, 820 & 4,317 & 70,686 & & & \\
\hline 6 &, 768 & 4,044 & 74,730 & & & \\
\hline 7 &, 560 & 2,949 & 77,678 & & & \\
\hline 8 &, 528 & 2,777 & 80,455 & & & \\
\hline 9 &, 516 & 2,713 & 83,169 & & & \\
\hline 10 & ,487 & 2,561 & 85,730 & & & \\
\hline 11 & ,420 & 2,211 & 87,941 & & & \\
\hline 12 & ,398 & 2,094 & 90,035 & & & \\
\hline 13 &, 361 & 1,900 & 91,934 & & & \\
\hline 14 & ,340 & 1,788 & 93,723 & & & \\
\hline 15 &, 314 & 1,651 & 95,374 & & & \\
\hline 16 & ,266 & 1,401 & 96,774 & & & \\
\hline 17 & 237 & 1,247 & 98,022 & & & \\
\hline 18 & ,201 & 1,060 & 99,081 & & & \\
\hline 19 & , 175 &, 919 & 100,000 & & & \\
\hline
\end{tabular}

Temel bileșenler analizi sonrasında elde edilen bileșen matrisinde de ölçeğin 4 faktörden oluștuğu anlașılmakla birlikte, belirgin bir faktör yapısı elde edilememiștir. Bu nedenle her bir faktörün yüklemelerini daha net olarak görerek faktörler arası karșılaștırmaya imkân vermek amacıyla elde edilen 4 faktörlük sonuç yönlendirmeye tabii tutulmuștur. Bu amaçla Varimax yönlendirme metodu kullanılmıștır. Sonuçlar Tablo 10 'da yer almaktadır. 
Tablo 10:

Temel Bileșenler Matrisi-3

\begin{tabular}{|c|c|c|c|c|}
\hline & \multicolumn{4}{|c|}{ Bileșen } \\
\hline & 1 & 2 & 3 & 4 \\
\hline 1. Șirketim çalıșanlarının egzersiz yapmasına önem verir. & ,680 & & & \\
\hline 2. Șirketim çalıșanlarının sağlıklı beslenmesine önem verir. &, 700 & & & \\
\hline 3. Șirket çalıșanlarına sağlıklı besinler yeterli ölçüde tanıtılmaktadır. & ,743 & & & \\
\hline $\begin{array}{l}\text { 4. Șirket çalıșanlarına uygun egzersiz alıșkanlıkları yeterli ölçüde } \\
\text { anlatılmaktadır. }\end{array}$ & .747 & & & \\
\hline 5. Șirket çalıșanları sağlıklı beslenmeye büyük önem vermektedirler. &, 718 & & & \\
\hline $\begin{array}{l}\text { 6. Șirket çalıșanları düzgün egzersiz yapmaya büyük önem } \\
\text { vermektedirler. }\end{array}$ & ,704 & & & \\
\hline $\begin{array}{l}\text { 7. Șirket çalıșanları birbirlerinin egzersiz alıșkanlıklarını } \\
\text { desteklerler. }\end{array}$ &, 700 & & & \\
\hline 8. Șirketteki çalıșanların büyük bir kısmı fiziksel olarak formdadır. & ,662 & & & \\
\hline 9. Șirket çalıșanları sağlıklı beslenmeye teșvik edilirler. & .786 & & & \\
\hline 10. Șirket çalıșanları sportif faaliyetlerde aktif olarak yer alırlar. & 695 & & & \\
\hline 11. Șirket çalıșanlarının büyük bir bölümü düzenli olarak spor yapar. &, 633 & & & \\
\hline $\begin{array}{l}\text { 12. Eğer formumu uygun beslenme ile geliștirmek istersem, bunu } \\
\text { ișyerimde kolaylıkla bașarabilirim. }\end{array}$ & ,656 & & & \\
\hline $\begin{array}{l}\text { 13. Eğer formumu düzenli egzersiz ile geliștirmek istersem, bunu } \\
\text { ișyerimde kolaylıkla bașarabilirim. }\end{array}$ & ,699 & & & \\
\hline $\begin{array}{l}\text { 15. İș ortamım bana egzersiz yapmak için gerekli zamanı } \\
\text { sağlamaktadır. }\end{array}$ & 657 &, 518 & & \\
\hline $\begin{array}{l}\text { 16. İș ortamım bana uygun beslenebilmem için gerekli zamanı } \\
\text { sağlamaktadır. }\end{array}$ & .604 & & & \\
\hline 18. Șirket yöneticileri de sağlıklı beslenirler. & .510 & &, 535 & \\
\hline $\begin{array}{l}\text { 21. Mesai saatleri dâhilinde sağlıklı egzersiz yapma konusunda } \\
\text { yönlendirme/rehberlik alma imkânına sahibim. }\end{array}$ & 687 & & & \\
\hline $\begin{array}{l}\text { 22. Șirket yöneticileri tüm çalıșanların sağlıklı beslenmesine özen } \\
\text { gösterirler. }\end{array}$ & ,713 & & & \\
\hline $\begin{array}{l}\text { 23. Șirket yöneticileri tüm çalıșanların düzenli egzersiz yapmasına } \\
\text { özen gösterirler. }\end{array}$ & ,742 & & & \\
\hline
\end{tabular}

Varimax yöntemi kullanılarak yapılan yönlendirme sonucunda elde edilen faktör yapısı aşağıda sunulmuștur:

\section{İșletmenin Egzersize Verdiği Önem ve Yönlendirme}

1. Șirketim çalıșanlarının egzersiz yapmasına önem verir.

4. Şirket çalıșanlarına uygun egzersiz alıșkanlıkları yeterli ölçüde anlatılmaktadır.

21. Mesai saatleri dâhilinde sağlıklı egzersiz yapma konusunda yönlendirme/rehberlik 
alma imkânına sahibim.

23. Șirket yöneticileri tüm çalıșanların düzenli egzersiz yapmasına özen gösterirler.

\section{İșletmenin Sağlıklı Beslenmeye Verdiği Önem ve Yönlendirme}

2. Șirketim çalıșanlarının sağlıklı beslenmesine önem verir.

3. Sirket çalıșanlarına sağlıklı besinler yeterli ölçüde tanıtılmaktadır.

5. Şirket çalıșanları sağlıklı beslenmeye büyük önem vermektedirler.

9. Șirket çalıșanları sağlıklı beslenmeye teșvik edilirler.

18. Sirket yöneticileri de sağlıklı beslenirler.

22. Șirket yöneticileri tüm çalıșanların sağlıklı beslenmesine özen gösterirler.

\section{İșletme Calıșanlarının Egzersize Verdikleri Önem}

6. Sirket çalıșanları düzgün egzersiz yapmaya büyük önem vermektedirler.

7. Șirket çalıșanları birbirlerinin egzersiz alıșkanlıklarını desteklerler.

8. Șirketteki çalıșanların büyük bir kısmı fiziksel olarak formdadır.

10. Sirket çalıșanları sportif faaliyetlerde aktif olarak yer alırlar.

11. Șirket çalıșanlarının büyük bir bölümü düzenli olarak spor yapar.

\section{İşyeri Ortamının Sağlıklı Beslenme ve Egzersiz İçin Uygunluğu}

12. Eğer formumu uygun beslenme ile geliștirmek istersem, bunu ișyerimde kolaylıkla bașarabilirim.

13. Eğer formumu düzenli egzersiz ile geliștirmek istersem, bunu ișyerimde kolaylıkla bașarabilirim.

15. İs ortamım bana egzersiz yapmak için gerekli zamanı sağlamaktadır.

16. İs ortamım bana uygun beslenebilmem için gerekli zamanı sağlamaktadır.

Bundan sonra yapılan analizlerde faktör bazında ortalamalar alınmıș ve her bir faktörün çalıșan sağlığına etkisi araștırılmıștır. Sonuçlar Tablo 11'de yer almaktadır.

Tablo 11:

Yönlendirilmiș Temel Bileșenler Matrisi

\begin{tabular}{|l|c|c|c|c|}
\hline & \multicolumn{3}{|c|}{ Bilesen } \\
\hline & $\mathbf{1}$ & $\mathbf{2}$ & $\mathbf{3}$ & $\mathbf{4}$ \\
\hline 1. Şirketim çalıșanlarının egzersiz yapmasına önem verir. & &, 703 & & \\
\hline 2. Şirketim çalıșanlarının sağlıkıı beslenmesine önem verir. & & &, 613 & \\
\hline 3. Şirket çalıșanlarına sağlıkı besinler yeterli ölçüde tanıtılmaktadır. & &, 504 &, 567 & \\
\hline $\begin{array}{l}\text { 4. Sirket çalıșanlarına uygun egzersiz alıșkanlıkları yeterli ölçüde } \\
\text { anlatımaktadır. }\end{array}$ & &, 741 & & \\
\hline 5. Sirket çalıșanları sağlıklı beslenmeye büyük önem vermektedirler. & & &, 563 & \\
\hline
\end{tabular}




\begin{tabular}{|c|c|c|c|c|}
\hline $\begin{array}{l}\text { 6. Șirket çalıșanları düzgün egzersiz yapmaya büyük önem } \\
\text { vermektedirler. }\end{array}$ & .658 & & & \\
\hline $\begin{array}{l}\text { 7. Șirket çalıșanları birbirlerinin egzersiz alıșkanlıklarını } \\
\text { desteklerler. }\end{array}$ & .628 & & & \\
\hline 8. Șirketteki çalıșanların büyük bir kısmı fiziksel olarak formdadır. & .710 & & & \\
\hline 9. Șirket çalıșanları sağlıklı beslenmeye teșvik edilirler. & & &, 551 & \\
\hline 10. Șirket çalıșanları sportif faaliyetlerde aktif olarak yer alırlar. & .697 & & & \\
\hline 11. Șirket çalıșanlarının büyük bir bölümü düzenli olarak spor yapar. & .755 & & & \\
\hline $\begin{array}{l}\text { 12. Eğer formumu uygun beslenme ile geliștirmek istersem, bunu } \\
\text { ișyerimde kolaylıkla bașarabilirim. }\end{array}$ & & & & ,773 \\
\hline $\begin{array}{l}\text { 13. Eğer formumu düzenli egzersiz ile geliștirmek istersem, bunu } \\
\text { ișyerimde kolaylıkla bașarabilirim. }\end{array}$ & & & & ,737 \\
\hline $\begin{array}{l}\text { 15. İș ortamım bana egzersiz yapmak için gerekli zamanı } \\
\text { sağlamaktadır. }\end{array}$ & & & & 678 \\
\hline $\begin{array}{l}\text { 16. İș ortamım bana uygun beslenebilmem için gerekli zamanı } \\
\text { sağlamaktadır. }\end{array}$ & & & & ,709 \\
\hline 18. Șirket yöneticileri de sağlıklı beslenirler. & & &, 705 & \\
\hline $\begin{array}{l}\text { 21. Mesai saatleri dâhilinde sağlıklı egzersiz yapma konusunda yön- } \\
\text { lendirme/rehberlik alma imkânına sahibim. }\end{array}$ & & .566 & & \\
\hline $\begin{array}{l}\text { 22. Șirket yöneticileri tüm çalıșanların sağlıklı beslenmesine özen } \\
\text { gösterirler. }\end{array}$ & & &, 735 & \\
\hline $\begin{array}{l}\text { 23. Șirket yöneticileri tüm çalıșanların düzenli egzersiz yapmasına } \\
\text { özen gösterirler. }\end{array}$ & & .534 & & \\
\hline
\end{tabular}

\section{Bulgular ve Yorum}

Bulgular yorumlanırken İș Ortamının Sağlıklı Beslenme ve Egzersiz İçin Uygunluğu”, “Şirketin Egzersize Verdiği Önem ve Yönlendirme”, “Şirketin Sağlıklı Beslenmeye Verdiği Önem ve Yönlendirme”, “Şirket Çalıșanların Egzersize Verdikleri Önem” bașlıkları altında incelenmiș ve her bir boyutun çalıșanların sağlığı üzerindeki görece etkisi karşılaștırmalı olarak sorgulanmıștır. Ayrıca araștırmanın örneklemine ilișkin demografik bilgiler tanımlayıcı istatistikler yardımıyla özetlenmiștir.

Örneklem grubunun demografik özelliklerine göre dağılımı frekans ve yüzde tanımlayıcı istatistikleri kullanarak incelenmiștir. Örneklem grubunun cinsiyetlerine göre dağılımları \%42 erkek, \%58 kadındır. Katılımcıların \%48'i evli, \%52'si bekârdır. Katılımcıların \%50'si 30 yașın altında iken, \%37'si 31-40 yaș arası, \%9'u 41-50 yaș arası, \%4'ü 51-60 yaș arasındadır. Araștırmanın ana hipotezleri sorgulanırken SB ve FA ile çalıșanların sağlık durumu arasındaki ilișki değerlendirilmiștir. 
Tablo 12:

FA ve SB ile Sağlık Durumu Arasındaki İlișki

\begin{tabular}{|c|c|c|c|c|c|c|}
\hline & & $\begin{array}{l}\text { Sağlık } \\
\text { Durumu }\end{array}$ & $\begin{array}{l}\text { İșletmenin } \\
\text { Egzersize } \\
\text { Verdiği } \\
\text { Önem ve } \\
\text { Yönlendirm }\end{array}$ & $\begin{array}{l}\text { İșletmenin } \\
\text { Sağlıklı } \\
\text { Beslenmeye } \\
\text { Verdiği } \\
\text { Önem ve } \\
\text { Yönlendirm }\end{array}$ & $\begin{array}{l}\text { İșletme } \\
\text { Çalıșanların } \\
\text { Egzersize } \\
\text { Verdikleri } \\
\text { Önem }\end{array}$ & $\begin{array}{l}\text { İș Ortamının } \\
\text { Sağlıklı } \\
\text { Beslenme ve } \\
\text { Egzersiz İçin } \\
\text { Uygunluğu }\end{array}$ \\
\hline \multirow{3}{*}{$\begin{array}{l}\text { Sağlık } \\
\text { Durumu }\end{array}$} & $\begin{array}{c}\text { Pearson } \\
\text { Korelasyonu }\end{array}$ & 1 &,$- 224^{* *}$ &,$- 250 * *$ &,$- 170^{* *}$ &,$- 272^{* *}$ \\
\hline & Anlamlılık & & ,000 & ,000 & ,001 & ,000 \\
\hline & $\mathrm{N}$ & 401 & 401 & 401 & 401 & 401 \\
\hline \multirow{3}{*}{$\begin{array}{l}\text { İșletmenin } \\
\text { Egzersize } \\
\text { Verdiği } \\
\text { Önem ve } \\
\text { Yönlendirme }\end{array}$} & $\begin{array}{c}\text { Pearson } \\
\text { Korelasyonu }\end{array}$ &,$- 224^{* *}$ & 1 &, $714^{* *}$ &, $678 * *$ &, $677^{* *}$ \\
\hline & Anlamlılık & ,000 & & ,000 & ,000 & ,000 \\
\hline & $\mathrm{N}$ & 401 & 401 & 401 & 401 & 401 \\
\hline \multirow{3}{*}{$\begin{array}{l}\text { İșletmenin } \\
\text { Sağlıklı } \\
\text { Beslenmeye } \\
\text { Verdiği } \\
\text { Önem ve } \\
\text { Yönlendirme }\end{array}$} & $\begin{array}{c}\text { Pearson } \\
\text { Korelasyonu }\end{array}$ &,$- 250 * *$ &, $714^{* *}$ & 1 &, $692 * *$ &, $610^{* *}$ \\
\hline & Anlamlılık & ,000 & ,000 & & ,000 & ,000 \\
\hline & $\mathrm{N}$ & 401 & 401 & 401 & 401 & 401 \\
\hline \multirow{3}{*}{$\begin{array}{l}\text { İșletme } \\
\text { Çalıșanların } \\
\text { Egzersize } \\
\text { Verdikleri } \\
\text { Önem }\end{array}$} & $\begin{array}{c}\text { Pearson } \\
\text { Korelasyonu }\end{array}$ &,$- 170 * *$ &, $678 * *$ &, $692^{* *}$ & 1 &, $554^{* *}$ \\
\hline & Anlamlılık & ,001 & ,000 &, 000 & &, 000 \\
\hline & $\mathrm{N}$ & 401 & 401 & 401 & 401 & 401 \\
\hline \multirow{3}{*}{$\begin{array}{c}\text { İșyeri } \\
\text { Ortamının } \\
\text { Sağlıklı } \\
\text { Beslenme ve } \\
\text { Egzersiz İçin } \\
\text { Uygunluğu }\end{array}$} & $\begin{array}{c}\text { Pearson } \\
\text { Korelasyonu }\end{array}$ &,$- 272^{* *}$ &, $677^{* *}$ &, $610 * *$ &, $554^{* *}$ & 1 \\
\hline & Anlamlılık & ,000 & ,000 &, 000 &, 000 & \\
\hline & $\mathrm{N}$ & 401 & 401 & 401 & 401 & 401 \\
\hline
\end{tabular}

Tablo 12'deki değerler, katılımcıların “İşyeri Ortamının Sağlıklı Beslenme ve Egzersiz İçin Uygunluğu”, “İșletmenin Egzersize Verdiği Önem ve Yönlendirme”, “İşletmenin Sağlıklı Beslenmeye Verdiği Önem ve Yönlendirme”, “ișletme Çalıșanlarının Egzersize Verdikleri Önem” faktörlerinden aldıkları puanlar ile “Sübjektif Sağlık Șikâyetleri” ölçeğinden aldıkları değerler arasında $\mathrm{p} \leftarrow, 0.01$ düzeyinde negatif bir ilișki olduğunu ortaya koymaktadır. Bu bulgudan hareketle ișyerindeki fiziksel aktivite ve sağlıklı beslenme hizmetlerinin niteliği yükseldikçe, çalıșanların sağlık șikâyetlerinin azaldığı söylenebilir. Bununla birlikte korelasyon analizi birden fazla bağımsız değișkenin tek bir bağımlı değișken üzerindeki bütünleșik etkisini göstermede sınırlılıkları olan bir analiz yöntemidir. Bu nedenle daha sağlıklı bir yorum yapabilmek için basamaklı (stepwise) çoklu 
regresyon analizi kullanılmıștır. Bu yöntemde tüm değișkenler bir arada denkleme sokulmakla birlikte, bağımlı değișken üzerinde anlamlı etkiye sahip olmayan değișkenler analiz dıșı bırakılmaktadır.

Bu çerçevede hesaplanan çoklu regresyon analizi sonuçları Tablo 13'de özetlenmiștir. Buna göre “İșyeri Ortamının Sağlıklı Beslenme ve Egzersiz İçin Uygunluğu” ve “İșletmenin Sağlıklı Beslenmeye Verdiği Önem ve Yönlendirme” faktörleri bağımlı değișken olan sağlık durumu üzerinde anlamlı etkiye sahiptir.

Tablo 13:

FA ve SB ile Sağlık Durumu Arasındaki İlișkiye Ait Çoklu Regresyon Analizi Sonuçları

\begin{tabular}{|c|c|c|c|c|c|c|}
\hline \multirow{2}{*}{\multicolumn{2}{|c|}{ Model }} & \multicolumn{2}{|c|}{ Standart Olmayan Katsayılar } & \multirow{3}{*}{$\begin{array}{c}\begin{array}{c}\text { Standart } \\
\text { Katsayılar }\end{array} \\
\text { Beta }\end{array}$} & \multirow[t]{2}{*}{$\mathrm{t}$} & \multirow[t]{2}{*}{ Anlamlılık } \\
\hline & & $\mathrm{B}$ & Std. Hata & & & \\
\hline \multirow[b]{2}{*}{1} & (Sabit) & 458,910 & 35,260 & & 13,015 &, 000 \\
\hline & $\begin{array}{l}\text { İşyeri } \\
\text { Ortamının } \\
\text { Sağlıklı } \\
\text { Beslenme ve } \\
\text { Egzersiz İçin } \\
\text { Uygunluğu }\end{array}$ & $-74,609$ & 13,227 &,- 272 & $-5,641$ &, 000 \\
\hline \multirow{3}{*}{2} & (Sabit) & 510,982 & 42,284 & & 12,085 &, 000 \\
\hline & $\begin{array}{l}\text { İşyeri } \\
\text { Ortamının } \\
\text { Sağlıklı } \\
\text { Beslenme ve } \\
\text { Egzersiz İçin } \\
\text { Uygunluğu }\end{array}$ & $-52,255$ & 16,609 &,- 190 & $-3,146$ &, 002 \\
\hline & $\begin{array}{l}\text { İșletmenin } \\
\text { Sağlıklı } \\
\text { Beslenmeye } \\
\text { Verdiği } \\
\text { Önem ve } \\
\text { Yönlendirme }\end{array}$ & $-43,603$ & 19,756 &,- 134 & $-2,207$ &, 028 \\
\hline
\end{tabular}

Tablo 14'de verilen Model Özetindeki değerler ise “isşyeri Ortamının Sağlıklı Beslenme ve Egzersiz İçin Uygunluğu” faktörünün r2 = ,074 oranında değișim yaratırken, “İșletmenin Sağlıklı Beslenmeye Verdiği Önem ve Yönlendirme" faktörü bunun üzerine $r 2=, 011$ derecesinde ek bir varyans açıklamaktadır. 
Tablo 14:

Model Özeti

\begin{tabular}{|c|c|c|c|c|c|c|}
\hline \multirow[b]{2}{*}{$\mathbf{R}$} & \multirow[b]{2}{*}{ R2 } & \multirow[b]{2}{*}{$\begin{array}{c}\text { Düzeltilmiş } \\
\text { R2 }\end{array}$} & \multirow[b]{2}{*}{ Std. Hata } & \multicolumn{3}{|c|}{ Değișim İstatistikleri } \\
\hline & & & & $\begin{array}{l}\text { R Kare } \\
\text { Değișimi }\end{array}$ & F Değiși & $\begin{array}{c}\text { F } \\
\text { Değișiminin } \\
\text { Anlamlılığı }\end{array}$ \\
\hline, 272 & ,074 & ,072 & 278,96969 & ,074 & 31,817 &, 000 \\
\hline ,292 & ,085 & ,080 & 277,62608 & 011 & 4,871 & ,028 \\
\hline
\end{tabular}

Tablo 15'de veriler ise "İșletmenin Egzersize Verdiği Önem ve Yönlendirme" ve "İșletme Çalışanların Egzersize Verdikleri Önem” faktörlerinin “İşyeri Ortamının Sağlıklı Beslenme ve Egzersiz İçin Uygunluğu” ve “İșletmenin Sağlıklı Beslenmeye Verdiği Önem ve Yönlendirme" faktörleri ile birlikte alındıklarında anlamlılıklarını yitirdiklerini göstermektedir. Tabloda bağımsız değișkenler iki gruba ayrılmıș ve bunların bağımlı değișken olan “sağlık durumuna" olan etkileri ortaya konmuștur.

Tablo 15:

Analiz Dıșı Bırakılan Değișkenler

\begin{tabular}{|c|c|c|c|c|c|c|}
\hline \multicolumn{2}{|r|}{ Model } & Beta & $t$ & Anlamlılık & $\begin{array}{c}\text { Kısmi } \\
\text { Korelasyon }\end{array}$ & Tolerans \\
\hline \multirow{3}{*}{1} & $\begin{array}{l}\text { İșletmenin } \\
\text { Egzersize } \\
\text { Verdiği Önem ve } \\
\text { Yönlendirme }\end{array}$ &,- 074 & $-1,138$ &, 256 &,- 057 &, 542 \\
\hline & $\begin{array}{l}\text { İșletmenin Sağlıklı } \\
\text { Beslenmeye } \\
\text { Verdiği Önem ve } \\
\text { Yönlendirme }\end{array}$ &,- 134 & $-2,207$ & ,028 &,- 110 & .628 \\
\hline & $\begin{array}{c}\text { İșletme } \\
\text { Çalıșanlarının } \\
\text { Egzersize } \\
\text { Verdikleri Önem }\end{array}$ &,- 028 &,- 489 & .625 &,- 025 & ,693 \\
\hline \multirow{2}{*}{2} & $\begin{array}{l}\text { İșletmenin } \\
\text { Egzersize } \\
\text { Verdiği Önem ve } \\
\text { Yönlendirme }\end{array}$ & ,000 &,- 002 &, 998 & ,000 &, 397 \\
\hline & $\begin{array}{c}\text { İșletme } \\
\text { Çalıșanlarının } \\
\text { Egzersize } \\
\text { Verdikleri Önem }\end{array}$ & ,056 & 819 &, 413 & ,041 &, 494 \\
\hline
\end{tabular}

Bu bulgulardan hareketle FA ve SB hizmetlerinin niteliği ile çalıșanların sağlık durumu arasında doğrusal bir ilișki olduğu, sağlık hizmetlerinin niteliği arttıkça çalıșanların sağlık durumun olumlu yönde geliștiği sonucuna varılmıștır. Ayrıca “İșyeri Ortamının Sağlıklı Beslenme ve Egzersiz İçin Uygunluğu” ve “İsletmenin Sağlıklı Beslenmeye Verdiği 
Önem ve Yönlendirme” çalıșan sağlığını doğrudan etkileyen faktörlerdir. “Ișletmenin Egzersize Verdiği Önem ve Yönlendirme” ve “issletme Çalıșanların Egzersize Verdikleri Önem” faktörleri ise yalnız bașlarına alındıklarında çalıșan sağlığını olumlu etkilemekle birlikte, analize diğer faktörler dâhil edildiğinde anlamlılıklarını yitirmektedirler.

Bu durum ișletmenin egzersize verdiği önemin zaten kendisini iș ortamındaki değișikliklerle göstereceği, iș ortamında değișiklik olmaması durumunda söz konusu önemin anlamını yitireceği ve bu nedenlerle “İșletmenin Egzersize Verdiği Önem ve Yönlendirme" faktörünün “İşyeri Ortamının Sağlıklı Beslenme ve Egzersiz İçin Uygunluğu” faktörünün varlığında çalıșanların sağlığına anlamlı bir katkı sağlamayacağı söylenebilir.

“İșletme Çalıșanlarının Egzersize Verdikleri Önem” faktörünün ise “İşyeri Ortamının Sağlıklı Beslenme ve Egzersiz İçin Uygunluğu” ve “issletmenin Sağlıklı Beslenmeye Verdiği Önem ve Yönlendirme" faktörleri ile birlikte anlamlılığını yitirmesi önemli bir bulgudur. Bu bulgu ișletmede sağlıklı bir beslenme ve egzersiz ortamı bulunması durumunda egzersize önem vermeyen çalıșanların dahi sağlık durumunun geliștiğini ortaya koymaktadır. Diğer bir ifade ile kurumsal düzenlemeler ve yönetimle ilgili yürütülen faaliyetler kișiyi kendi önceliklerinden daha fazla etkilemekte, egzersize önem vermeyen çalıșanlar dahi bu faaliyetlere iștirak ederek sağlık durumlarını geliștirmektedir. “İșletme çalıșanlarının sağlıklı beslenmeye verdiği önem” ise yeterli faktör düzeyi oluşturamadığı için buna ilișkin hipotez reddedilmiștir.

Tablo 16'da yapılan analizler sonucunda araștırmanın ana hipotezlerinin "kabul" veya "red" durumları özetlenmiștir.

Tablo 16:

Araștırmanın Hipotez Testi Sonuçları

\begin{tabular}{|c|l|c|}
\hline Hipotez No & \multicolumn{1}{|c|}{ Hipotezin İfadesi } & Sonuç \\
\hline $\mathbf{H}_{1}$ & $\begin{array}{l}\text { İșyeri ortamının sağlıklı beslenme ve fiziksel aktivite için uygunluğu ile çalıșan } \\
\text { sağlığı arasında ilișki vardır. }\end{array}$ & Kabul \\
\hline $\mathbf{H}_{2}$ & $\begin{array}{l}\text { İșletmenin sağlıklı beslenmeye verdiği önem ve yönlendirme ile çalıșan sağlığı } \\
\text { arasında ilișki vardır. }\end{array}$ & Kabul \\
\hline $\mathbf{H}_{3}$ & $\begin{array}{l}\text { İșletmenin fiziksel aktiviteye verdiği önem ve yönlendirme ile çalıșan sağlığı } \\
\text { arasında ilișki vardır. }\end{array}$ & Kabul \\
\hline $\mathbf{H}_{4}$ & $\begin{array}{l}\text { İșletme çalıșanlarının fiziksel aktiviteye verdiği önem ve yönlendirme ile çalı- } \\
\text { șan sağlığı arasında ilișki vardır. }\end{array}$ & Kabul \\
\hline $\mathbf{H}_{5}$ & $\begin{array}{l}\text { İșletme çalıșanlarının sağlıklı beslenmeye verdiği önem ve yönlendirme ile } \\
\text { çalıșan sağlığı arasında ilișki vardır. }\end{array}$ & Red \\
\hline
\end{tabular}


Çalıșanların sağlık durumları ile cinsiyetleri arasındaki ilișki t-testi kullanılarak incelenmiș ve analiz sonuçları Tablo 17'de sunulmuștur. Tablonun anlamlılık sütunundaki değerden ( $p=, 00 ; p<, 01)$ söz konusu değișkenler arasındaki ilișkinin istatistiksel olarak anlamlı olduğu anlaşılmaktadır.

Tablo 17:

Calıșanların Sağlık Durumu ile Cinsiyetleri Arasındaki İlișki

\begin{tabular}{|c|c|c|c|c|c|c|}
\hline \multicolumn{2}{|c|}{} & \multicolumn{2}{c|}{ Levene Testi } & \multicolumn{3}{c|}{ t-testi } \\
\cline { 3 - 7 } & F & Anlamlılık & t & df & Anlamlılık \\
\hline \multirow{3}{*}{$\begin{array}{c}\text { Sağlık } \\
\text { Durumu }\end{array}$} & $\begin{array}{c}\text { Varyansların Eșitliği } \\
\text { Varsayımı }\end{array}$ & 28,786 &, 000 & 6,187 & 399 &, 000 \\
\cline { 2 - 7 } & $\begin{array}{c}\text { Varyansların Eșitsizliği } \\
\text { Varsayımı }\end{array}$ & & & 5,798 & 266,994 &, 000 \\
\hline
\end{tabular}

Çalıșanların sağlık durumlarının cinsiyetlerine bağlı olarak değișimi ise Tablo 18'de sunulmuștur. Tablonun ortalama sütunundaki değerler kadınların algılanan sağlık șikâyeti puanlarının erkeklerin puanlarından daha yüksek olduğunu göstermektedir. Bu bulgu t-testi bulguları ile birlikte değerlendirildiğinde erkeklerin kadınlardan daha sağlıklı oldukları sonucuna ulașılmıștır.

Tablo 18

Çalıșanların Sağlık Durumunun Cinsiyetlerine Bağlı Olarak Değișimi

\begin{tabular}{|c|c|c|c|c|c|c|}
\hline & \multicolumn{2}{|c|}{ Cinsiyet } & N & Ortalama & Std. Sapma & Std. Hata \\
\hline \multirow{2}{*}{$\begin{array}{c}\text { Sağlık } \\
\text { Durumu }\end{array}$} & \multirow{2}{*}{ Dimension } & Kadın & 170 & 375,9235 & 341,82665 & 26,21691 \\
\cline { 3 - 7 } & & Erkek & 231 & 202,8139 & 217,15944 & 14,28804 \\
\hline
\end{tabular}

Çalışanların sağlık durumları ile medeni durumları arasındaki ilișki t-testi kullanılarak incelenmiș ve analiz sonuçları Tablo 19' da sunulmuștur. Tablonun anlamlılık sütunundaki değerden ( $p=, 25 ; p \rightarrow$,05) söz konusu değișkenler arasındaki ilișkinin istatistiksel olarak anlamlı olmadığı anlașılmaktadır. Bu bulgudan hareketle çalıșanların sağlık durumlarının medeni durumlarına bağlı olarak değișmediği sonucuna varılmıștır.

Tablo 19:

Çalıșanların Sağlık Durumu ile Medeni Durumları Arasındaki İlișki

\begin{tabular}{|c|c|c|c|c|c|c|}
\hline \multirow{2}{*}{} & \multicolumn{2}{|c|}{ Levene Testi } & \multicolumn{3}{c|}{ t-testi } \\
\cline { 3 - 7 } & F & Anlamlılık & t & df & Anlamlılık \\
\hline \multirow{3}{*}{$\begin{array}{c}\text { Sağlık } \\
\text { Durumu }\end{array}$} & $\begin{array}{c}\text { Varyansların Eșitliği } \\
\text { Varsayımı }\end{array}$ & 2,100 &, 148 & $-1,143$ & 399 &, 254 \\
\cline { 2 - 7 } & $\begin{array}{c}\text { Varyansların Eșitsizliği } \\
\text { Varsayımı }\end{array}$ & & & $-1,157$ & 388,340 &, 248 \\
\hline
\end{tabular}


Tablo 20:

Demografik Değișkenler İle İlgili Hipotezlerin Sonuçları

\begin{tabular}{|c|l|c|}
\hline Hipotez No & \multicolumn{1}{|c|}{ Hipotezin Ifadesi } & Sonuc \\
\hline $\mathbf{H}_{6}$ & Cinsiyet ile sağ ık durumu arasında ilișki vardır & Kabul \\
\hline $\mathbf{H}_{7}$ & Çalıșanların medeni durumu ile sağlık durumları arasında ilișki vardır. & Red \\
\hline
\end{tabular}

\section{Sonuç ve Öneriler}

Araștırmanın verilerinin analizinde elde edilen sonuçlar bu sektörde çalıșanların büyük bir bölümünün 30 yaș altında yer aldığını, bu grubun ardından da 31-40 yaș aralığında ki çalıșanların yer aldığını göstermektedir. Çok büyük bir çoğunluk üniversite mezunudur, çalıșanların yarıdan fazlası erkektir. Demografik özelliklere ilișkin bulgular çalıșanların çoğunluğunun milenyum kușağında, bir kısmının da X kușağında yer aldığını göstermektedir (Calabrese, 2010: 166). Dolayısı ile çalıșanların kent yașamını benimsemiș, sağlıktaki gelișmeleri takip eden, FA ve SB konularına duyarlı ve istekli oldukları düșünülmektedir. Araștırmanın yine bir diğer ilginç bulgusu da çalıșanların çok büyük bir çoğunluğunun ișveren destekli özel sağlık sigortasının bulunmasıdır.

Araștırmanın faktör analizi sonucunda elde edilen bulgular neticesinde ișyerinde fiziksel aktivite beslenmeye yönelik hizmetler bu hizmetlere ilișkin yürütülen yönetsel faaliyetler ve çalıșan sağlığı arasında bir ilișki kurulmaktadır. "İșletmenin egzersize verdiği önem ve yönlendirme”, "İșletmenin sağlıklı beslenmeye verdiği önem ve yönlendirme" “Iş̧letme çalışanlarının egzersize verdikleri önem” “isşyeri ortamının sağlıklı beslenme ve egzersiz için uygunluğu" șeklindeki bağımsız değișkenlerin çalıșan sağlığını ne düzeyde etkilediğini ortaya koymak adına olușturulan hipotezler ile korelasyon ve çoklu regresyon analizleri kullanılarak test edilmiștir. "İșletme çalıșanlarının sağlıklı beslenmeye verdiği önem ve yönlendirme" konusuna ilișkin sonuçlarda yeterli bir faktör olușumu belirlenememiștir.

Araștırmanın sonuçları ișletmelerin FA ve SB'e yönelik yönetsel faaliyetlerinin niteliklerini arttırdıkça çalıșan sağlığına ilișkin sonuçların daha olumlu olacağını destekler biçimdedir. Yönetsel faaliyetlerin niteliklerini arttıran faktörler birbirlerine kıyasla az veya çok çalıșan sağlığını etkiliyor olsa da bu faktörlerin her biri çalıșan sağlığına olumlu etkilerde bulunmaktadır. Bilișim sektöründeki ișletmelerin hizmetlerle ilgili yüksek maliyetlere katlanmadan önce hizmetlerin yönetimi ile ilgili ne gibi faaliyetler ve düzenlemeler yapmaları gerektiğini iyi belirlemeleri gerekmektedir. Dolayısıyla ișletmeler çalıșanların daha fazla zihin kullanmak zorunda olmalarını, masa bașında, hareketsiz daha fazla zaman geçirmek zorunda kalmalarını çalıșan sağlığı ile ilgili faaliyetleri yürütürken dikkate almalıdırlar. 
Araștırma aynı zamanda FA ve SB gibi çalıșan sağlığını geliștirici hizmetlere yönelik temel bir araștırmadır. Sonuçlar bu hizmetlerin sağlığa olumlu etkilerini desteklemekte, ileride yapılacak olan ve hizmetlerin verimlilik, prezenteizm ve örgütsel bağlılık gibiörgüt sorunlarına olan etkilerinin incelenebileceği araștırmalara bir temel olușturmaktadır.

\section{KAYNAKLAR}

Calabrese, John (2010) “Evolution Of Twenty-First Century Knowledge Workers" On The Horizon, 8(3), s.160-170.

Erdoğan, İrfan (2007) Pozitivist Metodoloji, 2.Baskı, Ankara: Erk.

Eriksen, Hege.; IhlabæK,Camila ; Ursin, Holger (2002) “Prevalence of Subjective Health Complaints in Norway", Scandinavian Public Health, 30(20),20-29.

Mazzola, Joseph J. (2010) Workplace Nutrition and Exercise Climate: Scale Development and Preliminary Model Test, Basılmamıș Doktora Tezi, Florida: Güney Florida Üniversitesi.

Mütercimler, Erol (2006) Geleceği Yönetmek ve Kazanmak lçin Stratejik Düşünme, İstanbul: Alfa.

Sağlık Bakanlığı (2010) Türkiye Obezite (SSișmanlık) Ile Mücadele ve Kontrol Programı 2010-2014, Ankara.

Stevens, James (2009) Applied Multivariate Statistics For The Social Sciences, New York: Taylor \& Francis Group.

Türker, Baș (2006) Anket Nasıl Hazırlanır? Uygulanır? Değerlendirilir?, Ankara :Seçkin. 


$$
\mid 108
$$




\title{
TÜM YÖNLERİYLE ESNEK ÇALIŞMA MODELLERI
}

\author{
YÜCEL ÖZTÜRKOĞLU (1)
}

\begin{abstract}
öz
Günümüz ekonomik șartlarında ișletmeler, her geçen gün yoğunlașan rekabet baskısını daha ağır olarak hissetmektedirler. Bu nedenle, yöneticiler ișletmelerinin varlıklarını sürdürebilmek için yeni arayıșlar içine giriyorlar. Artık, müșteri memnuniyetinin üst düzeyde sağlanabilmesi için iș gören memnuniyetinin de oldukça önemli olduğu yöneticiler tarafından bilinmektedir. Bu memnuniyeti arttırmanın farklı yollarından birisi de çalıșma sürelerinin esnekleștirilmesidir. Esneklikle ulașılmak istenen, her alanda değișen koşullara en kısa ve en iyi şekilde uyum sağlayarak, ișletmenin rekabet gücünü artırmaktır. Çalıșmanın tamamında esneklik, sürede esneklik anlamında kullanılacaktır ve sürede esneklik kavramı, esnek çalıșma saatleri ile ifade edilecektir. Bu çalıșmada, ülkemiz için henüz çok yeni olan esneklik kavramı tüm yönleri ile alınmıștır. En temel on bir esnek çalıșma modeli detaylı olarak incelenmiștir.
\end{abstract}

Anahtar Kelimeler: Esneklik, esnek çalıșma modelleri, esnek çalıșma saatleri JEL Kodları: M00, M12.

\begin{abstract}
In present economic conditions, companies feel more severe competitive pressure intensified with each passing day. Therefore, managers seek and embrace new management methods to survive. Today, managers know that in order to ensure the highest level of customer satisfaction, employee satisfaction is also very important. Making working hours more flexible is one way of increasing employee satisfaction. Companies seek to increase their competitiveness by adapting to changing circumstances in the best and quickest way with flexibility. Throughout the study, flexibility will be used in the sense of time flexibility and the concept of flexibility will refer to flexible working hours. This study takes all aspects of flexibility, which is still a quite new concept in Turkey, into account and examines in detail the eleven basic flexible working models.
\end{abstract}

Keywords: Flexibility, flexible working models, flexible working hours JEL Codes: M00, M12.

1 Yrd. Doç. Dr., Yaşar Üniversitesi, yucel.ozturk@ayasar.edu.tr 


\section{Giriș}

Tüm dünyada etkileri giderek yoğunlașan küreselleșme hareketleri ile birlikte, alabildiğince hızlanan teknolojik ilerlemeler çok kapsamlı değișimlere yol açmıștır. Son yıllarda, ekonomik sınırların neredeyse ortadan kalkması sonucunda, mal ve hizmetin oluș sürelerinin kısalması, ișin ve iș organizasyonunun yeniden yapılanması, ișçi ve ișverenleri her geçen gün daha çetin bir rekabet mücadelesi ile karșı karșıya bırakmıștır. Bu mücadeleye devam etmek için yeni arayıșlar içine giren sektörler son yıllarda önem kazanan esnekliğin avantajlarından azami ölçüde yararlanmaya çalıșırlar.

Esneklik, çağın getirdiği yeniliklere, ilerleyen teknolojilere beklenen uyumun sağlanması anlamına gelir. Esneklikle ulașılmak istenen amaç, her alanda değișen koșullara en kısa ve en iyi şekilde uyum sağlayarak, ișletmenin rekabet gücünü artırmaktır. Esneklik, ișletmelerin üretim kapasitesine, piyasa ve rekabet koșullarına daha fazla cevap vermek üzere katı kuralların yumuşatılarak taraflara daha çok serbestlik tanıyan bir çalıșma sisteminin benimsenmesidir (Karakoyunlu, 2003: 8). Esneklik ile iș, ișyeri ve mesai kavramları yeniden tanımlanır. Ayrıca mekânda ve zamanda kesin sınırların ortadan kalkması ile çalıșan kișilere bir takım özgürlükler verilerek motivasyonları büyük oranda artırılır. TiSK yaptığı bir çalıșmada esneklik kavramını; sayısal esneklik, uzaklaștırma stratejileri, fonksiyonel esneklik, ücret esnekliği ve sürede esneklik olarak sınıflandırmıștır (TiSK, 1999: 7).

Sayısal esneklik, ișletmelerin arz ve taleplerinde meydana gelebilecek kısa süreli değişikliklere cevap verebilmesi amacı ile ișgücünde, hem kalite hem de miktar açısından değișiklik yapılabilmesini ifade eder. Uzaklaștırma stratejileri, ișletmede yapılan bazı ișlerin bașka ișletmelere yaptırılması veya bazı hizmetlerin ișletme dıșındaki firmalardan sağlanması olarak ifade edilir. Fonksiyonel esneklik, talepteki değișikliklere veya sistemdeki farklılıklara uyum sağlama kabiliyeti olarak açıklanabilir. Fonksiyonel esneklik, miktarda esneklik, kalitede esneklik ve üretim süresinde esneklik olmak üzere farklı açılardan değerlendirilir (Köstekli, 2000: 47). Ücrette esneklik, çalışanların ücretlerinin, performanslarının değerlendirilmesi ve ișletmenin ekonomik yapısının dikkate alınması sonucunda, kișilere ve ișletmelere göre ayrı ayrı belirlenebilmesidir. Sürede esneklik, iș süresi işletme açısından, ihtiyaç duyulan zamanlarda ișin yapılması olarak tarif edilirken çalıșan açısından ise ișe bașlama ve iși bitirme saatlerinin kișisel istekler doğrultusunda belirlenmesidir. Bu durumda iș süresi, Türk İș Kanununun 61. Maddesinde belirtilenden farklı olarak ișveren ile ișçi arasında kararlaștırılır.

Bu çalıșmanın tamamında esneklik, sürede esneklik anlamında kullanılacaktır ve sürede esneklik kavramı, esnek çalıșma saatleri ile ifade edilmeye çalıșılacaktır. Esnek çalıșma saatleri normal çalıșma süresinin, ișe bașlama saatinin ve mola zamanlarının farklılașması ile ortaya çıkar. Ülkemizde normal çalıșma süresi, 4857 sayılı yeni İș Ka- 
nununa göre, günlük çalıșma süresi fazla çalıșma ücreti ödenmeksizin haftanın her gününe eșit biçimde dağılmıș olarak, günlük 11 saate kadar çıkarılmakla 6 iș günü temel alındığında haftada 66 saat olarak belirlenmektedir. Esnekleștirme sürecinde, ișveren ve iș gören tarafları karșılıklı anlașma yoluyla çalıșma zamanını, yer, süre ve dağılım bakımından tercihleri doğrultusunda yeniden düzenlerler. Çalıșma zamanının ne kadar esnek olduğu, ișveren ve iș görenlerin tercihlerini, hangi ölçüde yansıttığı ile ölçülür.

Esnek çalıșma saatleri uygulamasının yararları șöyle sıralanabilir (Crompton, 2002): Uygun bir șekilde kullanıldığı takdirde trafik sorununun çözümüne önemli katkılar sağlar. İs görenlerin performans arzlarının zaman içindeki dağılımından yararlanılır. Çalışma saatleri, performansın yüksek olduğu zaman aralığına göre yeniden düzenlenerek, işgücü verimliliğinde artıș sağlanır, dolayısıyla ișletmenin verimliliği de yükselir. İșletmenin daha uzun süreli hizmet vermesine, dolayısıyla daha yüksek kapasite kullanımına olanak tanıdığı için, yatırımların geri dönüș hızı olumlu etkilenir. Sık izin alma, ișe devamsızlık ve kısa sürede iș değiștirme gibi sorunlar azalır. Calıșma saatlerinin esnekleștirilmesi ișletmenin müșterilerin hizmet ihtiyaçlarını karșılama imkânını arttırır. İșletmenin hizmet verdiği zaman aralığı müșterinin talebi doğrultusunda olacağı için müșteri memnuniyeti artar. Günlük çalıșma süresinin uzaması fazla mesaiyi önler. Talebin yoğun olduğu dönemlerde yüksek maliyetli fazla mesai yapma zorunluluğu çalıșma saatlerinin talebe uygun hale getirilmesi ile ortadan kalkar. Ayrıca, iş gücü ve dolayısıyla üretim maliyetleri düșer. İșveren, çalıșanlarını, makinelerini ve teçhizatlarını çok daha uzun süreli ve efektif kullanma kabiliyetini kazanır. Bu verimliği artırır, çevrim süresinin ve teslim zamanının kısalmasını sağlar. Sonuç olarak kaynakların etkin kullanılması nedeniyle maliyetler düșer. Çalıșanların motivasyonu artar, iș görenin talebi doğrultusunda düzenlenen çalıșma zamanında, çalıșan kiși daha çok motive olur, daha az hata yapar ve daha verimli çalıșır. İșletmeye bağlılığı artar, ișletmenin amaçları ile iş görenin amaçlarının aynı doğrultuda olması sağlanır. Geniş karar alanı sağlar ve zamanı iyi kullanma becerisi kazandırır. İs görenin çalıșma zamanına kendisinin karar vermesi kișisel sorumluluk tașıma kabiliyetini ve özgüvenini geliștirir. Çalıșma saatlerini kendisinin ayarlayabilmesi, iş görenin iș hayatı ile özel hayatını uyumlu biçimde yürütebilmesini sağlar. Kendi çalıșma zamanını ihtiyaçları ve tercihleri doğrultusunda düzenleyebilen bir iș gören daha verimli çalıșacağı için ișten çıkarılması riski azalır ve iş yerine güveni artar. Esnek çalıșma zamanının uygulanması sonucunda ortaya çıkan hatasız ürün, zamanında malın teslim edilmesi, müșteriye uygun servis zamanın belirlenmesi gibi bütün avantajlarından müșteriler de yararlanır.

\section{Esnek Çalıșma Modelleri}

Esnek çalıșma modelleri, verim düșüklüğünün giderilmesi ve ișyerlerinin kesintisiz çalıștırılması konusunda etkin bir yol olduğundan ișverenler tarafından tercih edilirken, çalıșanlara ise çalıșma saatleri bakımından seçenek sağlayabilme imkânı tanıdığı için 
iș gören tarafından da sıcak yaklaşılan uygulamalardır (Mahiroğulları, 2005: 49). Gelecekte esnek çalıșma yöntemlerinin eğilimini araștıran Trade Union Congress tarafından yapılan bir araștırmanın sonuçlarına göre (Duck, 1999: 10) yakın gelecekte esnek çalıșma yöntemleri, çalıșma hayatında yer alan taraflar arasındaki ilișkilerde daha önemli rol oynayacaktır. Gerek çalıșanlar gerekse ișverenler tarafından esnek çalıșma yöntemlerine olan talep giderek ivme kazanacaktır. Gelecekte genel kabul görecek olacak çalıșma ilișkileri günümüz çalıșma ilișkilerinden oldukça farklı șekillenecektir. İș gören ile ișveren arasında, esnek çalıșma șekilleri toplu sözleșme görüșmelerinde yer alan ana konulardan biri olacaktır. Kısmi süreli çalıșma artmaya devam ederken, işyerinde esneklik arayıșları daha fazla yaratıcılık gerektirecektir.

Tüm dünyada kabul edilmiș toplam 11 farklı esnek çalıșma modelleri bulunmaktadır. Çalıșmanın bundan sonraki bölümlerinde, Tablo 1'de belirtilen esnek çalıșma modelleri detaylı olarak incelenmektedir.

\section{Tablo 1:}

\section{Esnek Çalıșma Modelleri}

\begin{tabular}{|l|}
\hline 1. Kısmi Süreli Çalıșma \\
a. Klasik Kısmi Süreli Calıșma \\
b. Esnek Kısmi Süreli Çalıșma \\
2. İs Paylașımı \\
a. Bölünmüș Gün \\
b. Bölünmüș Hafta \\
c. Dönüșümlü Hafta \\
d. Belirli Olmayan Dönüșümler \\
3. Kayan (Esnek) İș Süresi \\
a. Basit Kayan İs Süresi Modeli \\
b. Vasıflı Kayan İs Süresi \\
4. Cağrı Üzerine Çalıșma \\
5. Evde Çalıșma \\
6. Tele (Uzaktan) Çalıșma \\
a. Evde Büro \\
b. Uydu büro \\
c. Komșu Büro \\
d. Gezici Büro \\
7. Ödünç İș İlișkisi \\
8. Yoğunlaștırılmıș İs Haftası Modeli \\
9. Yıllık İs Süreleri Modeli \\
10. Emekliliğe Yumușak Geçiș Modeli \\
11. Vardiya Modelleri \\
\hline
\end{tabular}




\section{a. Kısmi Süreli Calıșma}

İșyerinde normal çalıșma saatlerinden daha kısa süre ile çalıșmaya part-time çalıșma, kısmi süreli çalıșma veya yarı zamanlı çalıșma denilmektedir. Kısmi süreli çalıșmanın temel özelliği normal çalıșma süresinden kısa olması, düzenli yapılması ve isteğe bağlı olmasıdır. Kısmi süreli çalıșma, Türk İș Kanunu düzenlenmediği gibi, kanuni herhangi bir tanımı da yapılmıș değildir. Uluslararası Çalıșma Örgütü (ILO) ise kısmi süreli çalıșmayı "ișçi ile ișveren arasında karșılıklı anlașma ile olușan ve normal iș süresinden daha kısa olan düzenli çalıșma"olarak tanımlamaktadır (Centel ve Süzek, 2002).

Kısmi süreli ișin tanımı konusunda ülkeler arasında ortak bir yaklașım söz konusu değildir. İngiltere yasalarına göre, kısmi süreli çalıșma bir haftada toplam 30 saatin altındaki çalıșma șekli olarak ifade edilir. Fransa'da yasal ve toplu sözleșmelerle, o ișletme için esas alınan haftalık çalıșma süresinin \%80'i kadar olan istihdam türleri, İspanya'da ise haftalık normal çalıșma süresinin üçte ikisinin altında kalan ișler kısmi süreli çalıșma saati olarak ifade edilmektedir. Danimarka'da ise kısmi süreli çalıșma saati ișverenler ve sendikalar arasında yapılan anlașma yoluyla belirlenir (ILO, 1993: 5).

Kısmi süreli çalıșma modellerinin üç önemli unsuru bulunmaktadır. Bunlar süre, süreklilik ve serbest irade olarak tanımlanır.

Süre: Kısmi süreli çalıșma, süresi kısaltılmıș bir çalıșma șeklidir. Kısmi süreli çalıșmadan söz edebilmek için iș görenin çalıșma süresinin, çalıștığı işyerinde uygulanan normal çalıșma süresinden kısa olması gerekir. Kısmi süreli çalıșmalarda çalıșma süresi ülkeden ülkeye farklılık gösterir. Bazı ülkelerde haftalık çalıșma süresinden daha az çalıșılırken, bazı ülkelerde ise normal çalıșma süresinin \%20'si ve daha azı çalıșma saati olarak kabul edilir. Ayrıca, kısmi süreli çalıșmayı "belli bir saatin altında çalıșmalar" olarak kabul eden ülkeler de bulunmaktadır.

Süreklilik: Kısmi süreli çalıșmanın ikinci unsuru sürekliliktir. Bu çalıșmanın sürekli ve düzenli olması, kısmi süreli çalıșmayı kısa süreli çalıșmadan ve belirli süreli çalıșmadan ayırt eden bir unsurdur. Kısa süreli çalıșma geçicidir, sürekli değildir.

Serbest Irade: Kısmi süreli çalıșmanın son unsuru ise serbest iradeye bağlı olmasıdır. Yani, kısmi süreli çalıșmanın gönüllü olarak, çalıșan kimsenin kendi istek ve tercihi ile yapılmasıdır. Ancak bu unsur tartıșmaya açıktır. Uygulamada, kısmi süreli çalıșmanın ișgören ile ișveren tarafından kararlaștırıldığı durumlar dıșında, sadece ișveren tarafından öngörüldüğü çok sayıda kısmi süreli çalıșma da bulunmaktadır. İşçinin bu tip çalıșma modelini serbest iradesi dıșında, sadece ișsiz kalmamak için kabul ettiği bilinmektedir. Kısmi çalıșmanın ișverenler açısından yararları șunlardır: Kısmi süreli çalıșanlar, günlük çalıșma sürelerinin az olması nedeniyle ișlerine daha fazla dikkat gösterirler. Bu 
da kısmi süreli çalıșanların tam zamanlı çalıșanlara göre verimliliklerini artıran önemli bir unsurdur. Kısmi süreli çalıșan iş görenlerden, tam zamanlı çalıșan iș görenlerin bulunamadıkları dönemlerde veya ara verdikleri zamanlarda yararlanılabilir. İșe gelmeme veya geç gelme durumu kısmi süreli çalıșanlarda daha az görülür. Diğer taraftan, yıllık izinler gibi öngörülebilen veya hastalık nedeniyle ișe gelememe gibi beklenmeyen durumlarda kısmi süreli çalıșan iș görenler kullanılarak üretim veya hizmetin devamlılığı sağlanır. Kısmi süreli çalıșan iș görenlerin istihdam edilmesi halinde, ișyerindeki makinelerin ve donanımların uzun süreli kullanılabilmesi imkânı doğar. Ayrıca genellikle perakende satış yapan yerlerin geç vakte kadar hizmet sunabilmesi sağlanır. Normal çalıșma süresine ilave edilen kısmı süreli çalıșma ile çalıșma saatinin uzatılması, fazla mesai ödemelerini gereksiz kılarak maliyetlerde azalmaya neden olabilir. Tam gün çalıșan iş görenlere ödenen ekstra sosyal yardımların kısmi süreli çalıșan iş görenlere ödenmemesi nedeniyle, maliyetlerde düșüș sağlanabilir. Ayrıca, ișletmenin girdiği ișkolunda genel ekonomik durumda meydana gelen dalgalanmalara paralel olarak, üretimin azaltılması veya artırılmasının gerektiği dönemlerde iș sürelerinin de kısmi süreli çalıșan iș gören kullanmak suretiyle azaltılması veya arttırılması mümkün olabilir.

Kısmi süreli çalıșmanın ișverenler açısından avantajlarının yanı sıra dezavantajları da vardır; sabah veya öğleden sonra ișe gelmek isteyenler arasında problemler yașanabilir. Kısmi süreli çalıșan iş görenler çalıșma saatlerinin gün içinde değiștirilmesine sıcak bakmayabilirler. Kısmi süreli çalıșan iș görenler iș yerlerinde tam gün çalıșanlara göre daha kısa süre bulundukları için kendilerini, ișletmeye ait hissetmezler. Kısmi süreli çalıșanların istihdamına ilișkin idari masrafları, tam gün çalıșanlar kadar yüksek olabilir. İșçi devir hızı kısmi süreli çalışanlarda daha yüksek olmaktadır. Kısmi süreli çalıșanlar, ihtiyaç duyulduğunda diğer șehirlere ve bölgelere seyahat etme konusunda gönülsüz davranabilmektedir.

Kısmi süreli çalıșma Türk iș mevzuatında düzenlenmediği gibi kanuni herhangi bir tanımı da yapılmıș değildir. Bu konuya ilișkin AB'nin 15 Aralık 1997 tarihli 97/81 sayılı "kısmi süreli çalışma" direktifi bulunmaktadır. İlgili direktifin amaçlar kısmında "kısmi süreli işçi veya işler" tanımlaması geniș tutulmasına rağmen İș Kanunu Tasarısında sadece "kısmi iş sözleșmesi" tanımı yapılmıștır. Bu tanımdan yola çıkarak kısmi süreli çalıșmanın, ișçinin normal haftalık çalıșma süresinin, tam süreli iș sözleșmesiyle çalışan emsal ișçiye göre önemli ölçüde daha az belirlendiği çalıșma biçimi olduğu anlașılır. Kısmi süreli çalıșma, 4857 sayılı İș Kanununun 13. ve 14. maddelerinde düzenlenmiștir. Bu düzenlemenin amacının, Bakanlar Kurulu Genelgesinde sayıları gittikçe artan kısmi çalıșmaları teșvik etmek, ișverenlerle ișçilerin ihtiyaçlarını karșılayacak șekilde çalıșma sürelerinin esnek bir organizasyon çerçevesinde düzenlenmesine katkıda bulunmak biçiminde olduğu belirtilmektedir (Türk-İs, 2003:18).

Günümüzde gelișmemiș ülkelerde sınırlı bir uygulama alanına sahip olan kısmi süreli 
çalıșma, ișsizliği önlemek ve esnekliği sağlamak amacıyla uygulanmaktadır. AB ülkelerinde, istihdamda görülen artıșın büyük çoğunluğunu kısmi süreli çalıșma türlerinde meydana gelen hızlı artış olușturmaktadır. Örneğin, Hollanda'da, 1980'li yıllarda, istihdamda meydana gelen artışın 2/3'ü kısmi süreli istihdam türlerinden meydana gelmiștir. 1991 yılında, İngiltere'de, tam gün istihdam edilenlerin sayısında önemli bir düșüs görülmüștür. Aynı dönemde Belçika, Almanya, İtalya, Hollanda ve Portekiz'de görülen istihdam artıșının önemli bir bölümünü kısmi süreli çalıșma olușturmaktadır (Tiziano, 1992: 4).

Yapılan araștırmalar, Avrupa Birliği ülkelerinde çalıșanların 1/7'sinin kısmi süreli çalıștığını, kısmi süreli istihdamın son on yılda büyük bir ilerleme gösterdiğini ortaya koymaktadır. En yüksek kısmi süreli çalıșma oranı 2000 verilerine göre \% 41,2 ile Hollanda'dadır. İngiltere, İsvec, Danimarka ve Belçika'da toplam istihdamın \%20'sinden fazlasını kısmi süreli çalıșanlar olușturmaktadır. Bu oran İrlanda, Fransa, Avusturya, Almanya'da \%15'in, Portekiz, Lüksemburg ve Finlandiya'da \%10'un üzerindedir. Sadece İtalya, İspanya ve Yunanistan'da \%10'un altındadır (Tiziano, 1992:, 5). Ülkemizde ise kısmı süreli çalıșanların toplam istihdam içerisindeki payı \% 5,8'dir ve bunun \%63,7'sini de kadınlar olușturmaktadır (Centel, 1992: 45). Kısmi süreli çalıșma kendi içinde klasik ve esnek kısmi süreli çalıșma olarak iki ayrılır.

\section{i) Klasik kısmi süreli çalıșma}

Klasik kısmi çalıșma, ișyerindeki normal iș süresine oranla daha az süreli çalıșma saatlerini içeren ve çalıșma saatlerinin miktarı ile konumunun önceden kesin biçimde belirlendiği bir çalıșma türüdür. Klasik tipteki çalıșmaya, uygulamada "yarım gün çalıșma" ve "kısmi vardiya çalıșması" biçiminde rastlanır. Öğleden önce veya sonra ya da akșam yapılan ve süresi genellikle normal günlük iş süresinin yarısı kadar olan yarım gün çalıșmaya, ișletmenin daha uzun süreyle açık tutulması ve yapılacak ișlerin yığılmasından veya azlığından doğan ișgücü gereksinimlerini karșılamak amacıyla bașvurulur. Ayrıca ișlerin yığılmasını önlemek üzere, haftanın veya ayın belirli günlerinde tam gün veya kısaltılmış çalıșma saatleriyle çalıșma durumları da uygulamada karșılașılan klasik kısmi çalıșma biçimleri içinde yer alır. Kısmi vardiya çalıșmasında ise, ya ișletmedeki günlük normal iș süresi vardiya sayısına bölünerek yada değișik uzunlukta ve konumda bulunan vardiyalar aracılığı ile ișletmenin günlük normal iş süresi uzatılır. Bunlardan ilki, ișten çıkarmaları önleme ve verimliliği yükseltme gibi düșüncelerden kaynaklanırken, diğeri ise daha çok işyerinin uzun süreli açık tutulmasında gerekli personel gereksinimini giderme amacını güder (Centel, 1992: 55).

\section{ii) Esnek kısmi süreli çalıșma}

Esnek kısmi çalıșma kavramı, ișyerindeki normal iș süresine oranla daha az çalıșma sa- 
atlerini içeren ve bunların miktar ile konumunu belirleme yetkisinin taraflara bırakıldığı çalıșma biçimini anlatır. Esnek kısmi çalıșmanın klasik kısmi çalıșma biçimlerinden ayrılan en önemli özelliği, çalıșma süresinin uzunluğunu ve dağılımını belirleme olanağının iş görene veya ișverene tanınmasıdır. Bu anlamda, esnek kısmi çalıșma, geleneksel türdeki kısmi çalıșmadan farklı olarak kesin çalıșma saatlerinin yerine, esnek çalıșma saatleri anlayıșını içerir (Centel, 1992: 56).

\section{b. İș Paylașımı}

İs paylașımı, tam gün süreli bir ișin ve onun sağladığı yararların birden fazla ișçi tarafından paylașılmasıdır. Bu modelde, hizmetin sağlanması görevi, birden çok sayıdaki iș gören tarafından paylașılıp üstlenilmektedir. Bir başka deyișle "tam gün" niteliğindeki bir ișin yapılması birkaç iș gören tarafından günün belirli saatlerinde sırasıyla ișe gelinerek gerçekleștirmekte ve bu iș için öngörülen ücret ve diğer sosyal haklar iși paylașan iş görenler arasında bölüșülmektedir. İși paylașan iș görenlerin her biri ile ișveren ayrı iș akdi yapar. İ paylașım sözleșmesinde kimin ne zaman çalıșacağına iş görenler karar verir (Yavuz, 1995: 78 ).

Bu çalıșmayı kısmi çalıșmadan ayıran en önemli özellik, ișin "tam gün” olmasıdır. Kısmi çalıșmada ise iș, niteliği itibariyle günün belirli bir zaman dilimi içinde bir kiși tarafından gerçekleștirilir. İs paylașımı, tam gün süre ile çalıșmanın avantajları ile kısmi süreli çalıșmanın yararlarını birleștiren bir sistemdir.

İs paylașımında üzerinde durulması gerekli üç önemli özellik mevcuttur. Bunlardan ilki iș süresinin iș görenler tarafından belirlenebilmesi, ikincisi iș paylașımına giren iș görenlerin ekip olușturması ve üçüncüsü tüm üyelerin birbirinin yerini alma anlayıșının hâkim olmasıdır. Burada en önemli nokta, iși paylașanların, çalıșma süresi içinde ișin durmaksızın sürdürülmesi sorumluluğunu üstlenmeleridir. İs paylașımı, çalıșanlara, çalıșma sürelerini düzenlemede daha fazla serbestlik tanıyan bir sistemdir. Bir iș gören kendi çalıșma süresi içerisinde yapması gereken ișin tamamını herhangi bir nedenle yerine getiremez ise bu eksik aynı iș sorumluğunu tașıyan diğer iș görenler tarafından karșılanabilir. İs paylașımının yaygın olarak dört farklı uygulama șekli bulunmaktadır (Yavuz, 1995: 78 ).

Bölünmüş Gün: İs paylașımında bulunanlar her gün yarım gün çalıșırlar. Örneğin, iș görenlerden biri sabah çalıșırken diğeri öğleden sonra ișbașı yapar. Bölünmüs Hafta: Çalıșma süresi gün olarak değil hafta olarak bölünmektedir. İs paylașanlardan biri haftanın ilk yarısında (örn. pazartesi, salı, çarșamba öğleye kadar) çalıșırken diğeri ikinci yarısında çalıșır. Bu, iș paylașımında en çok görülen uygulama biçimidir. Dönüșümlü Hafta: Calıșanlar haftayı bölmeden bir hafta boyunca çalıșmaktadırlar. Bu model de, iș paylașanlardan biri bir tam hafta çalıșırken, diğeri bir sonraki haftayı tam olarak çalıșır. 
Genellikle ișe geliș ve gidișlerin sorunlu olduğu uzak yerlerde bulunan ișyerleri ya da işyerlerinden uzak yașayan çalıșanlar tarafından tercih edilir. Belirli Olmayan Dönüsümler: Bu uygulama șeklinde iș paylașımı, iș gören ve ișverenlerin ihtiyaçlarına göre düzenlenir. Çalıșma süresinin nasıl paylașılacağı belli bir takvime bağlı olmaz. Çalıșma sürelerinin önceden bilinmesi mümkün değildir. İși paylașanlar ile iși verenlerin ișbirliği ile çalıșma süresi tespit edilir. İș paylașımının bu türü, ișletme içi esnekliği önemli ölçüde artırmaktadır.

İs paylașımının ișveren açısından başlıca faydaları; iș gücü devir hızının azalmasıdır. İs paylașımı, ișe giriș-çıkıșların sayısının azalmasına yardımcı olur. Çünkü bazı ișlerin rutin veya yorucu olması bu ișlerde giriș-çıkıșın artmasına neden olabilir. Bu tür ișlerin bir kaç ișçi tarafından paylaşılarak gerçekleștirilmesi halinde ișten çıkıșlar da azalabilir. İșverenler tam gün ișin kișisel ihtiyaçlara uyumlu olmaması nedeniyle nitelikli çalıșanlarını kaybedebilir. İ paylașımı bu nitelikli elemanların iște tutulabilmesini sağlamak açısından da önemlidir. İșe gelmemenin önlenmesi: İs paylaşımı ile ișçi, kendisine ayırabileceği daha çok zaman elde ettiği için kișisel nedenlerden dolayı ișe gelememe durumlarını en aza indirir. Sürekliliğin sağlanması: İs paylașanlardan biri hasta olsa ya da izin alsa, ișin diğer yarısı yapılmaktadır. Diğer iș paylașanın bu gibi durumlarda geçici olarak daha fazla çalıșması da mümkün olabilir. İș bașında konsantrasyonun artması: İs paylașanın çalıșma süresinin tam gün çalıșana göre daha az olması nedeniyle ișine daha çok özen gösterip, daha çok enerji sarf etmesi beklenir. Bu durum özellikle sıkıcı, rutin ve fiziksel yorgunluğa neden olan ișlerde önem kazanır. İşcilerin yeteneklerinden daha fazla yararlanılabilmesi için iș paylaşımı, ișverenlere iş görenlerin yetenek ve bilgilerini doğru yerde kullanabilme imkânını sağlamaktadır. Bir iș gören için bir günde katlanılacak maliyet yerine, aynı iși bir günde daha kısa süre çalıșıp aynı maliyete katlanılarak yapan iki iș görenin bilgi ve yeteneğinden yararlanılması söz konusudur. Geniș istihdam havuzunun olușturulması: İ ș paylașımı ișverenlerce daha kapasiteli kișilerin ișe alınmasını mümkün kılmaktadır. Nitelikleri iyi olup tam gün çalıșma imkânı olmayan kișilerden bu șekilde yararlanmak mümkündür. Gençler için daha iyi meslek eğitimi: Bazı ișverenler çok sayıda gencin iș yerinde eğitim görmesini iş paylaşımı ile gerçekleștirebilir. İ paylașımı ile eğitim gören sayısı iki katına çıkabilirken, bunlara yapılan masrafların iki katına çıkması söz konusu olmayabilir. Emekliliğe yumușak geçiș imkânı tanıması: İș paylașımının, emekliliğine az kalanlar arasında uygulanması halinde de birçok yararı söz konusudur. Azaltılmıș iș saatleri emekliliğine az kalanlara tam gün çalıșma ile tam gün boş zaman arasında bir geçiș süreci yaratır. Bunun yanında, mesleki eğitim gören, staj yapan ya da iș bașı eğitimi alan genç ișçilere bu eğitimlerini tecrübeli ișçilerle birlikte yapma imkânı sağlar.

İs paylaşımı, ișveren açısından belirtilen yararları yanında, özellikle ekonomik darboğazların yașandığı ve ișsizliğin yüksek olduğu dönemlerde hükümetler tarafından ișsizliğin önüne geçilmesinde uygulanan tedbirler arasında yer almaktadır. İş paylașımında 
bir ișin birkaç kiși tarafından yapılabilmesi sayesinde ișsizlerin sayısında da bir azalma olabilmektedir. İş paylașımının belirtilen avantajları yanında, ișveren açısından dezavantajlarını da sıralamak mümkündür: İdari masraflar; bir iște iki kișinin istihdam edilmesi halinde ișyerinin personel bölümünün yükü artabilir buraya yapılan masraflar da yükselebilir. İletișim; iș paylașımı yapanların her türlü yeni ve farklı bilgiden haberdar olabilmesi için çok daha dikkat gösterilmesi gerekecek; diğer taraftan, ișin bir ișçiden diğer ișçiye devredilmesi esnasında ișçilerin iletișim kurabilmesi için ilave bir süreye ihtiyaç duyulacaktır. Denetim; iș paylașımı uygulanan ișlerin denetimi ve kontrolü ile bunların paylaştırılması ve koordine edilmesi sırasında yöneticilerin daha fazla çaba ve özen göstermesi gerekir. Sorumluluğun dağıtılması; iș paylașımı yapanlar arasında üstlendikleri sorumluluklar bakımından farklılıklar bulunması halinde, ișin yürütülmesi sırasında bazı sorunlar ortaya çıkabilir. Gecikme; iș paylaşımı yapan ișçilerden birinin ișe geç gelmesi durumunda özellikle diğer ișçinin, bu ișçinin yaptığı bazı ișleri bilmemesi halinde sorunlar yașanabilir.

Tam gün süreli istihdama göre kısmi süreli çalıșmada ücretin daha az olması ve yükselme olanaklarının sınırlı olması, iş görenler açısından dezavantaj olarak görülmektedir. İs paylaşımı ilk olarak ABD'de uygulanmıș, daha sonra Avrupa'da denenmiștir. Ülkemiz düzenlemeleri göz önüne alındığında, iș paylașımına benzeyen çalıșma biçimi olarak, 1475 sayılı İș Kanununun 10. maddesinde yer alan takım sözleșmesi örnek gösterilebilir. Ancak iş paylaşımını takım sözleșmesinden ayıran bazı farklılıklar vardır. Bunlar is görme sorumluluğu ve ücret talep hakkıdır.

Iș Görme Sorumluluğu: İs paylașan ekibe ait iș görme borcu, bunlar arasındaki iç ilișkiye dayanırken takım sözleșmesinde iș görme borcu, iș gören ile ișveren arasında doğrudan yapılan sözleșme ile olușur. Ücret Talep Hakkı: İ paylașımında ücret talep hakkı gruba ait iken, takım sözleșmesinde ișveren ya da ișveren vekili iș görenlerin her birine ücret ödemek zorundadır.

Diğer taraftan İs Kanununun iș sürelerine ilișkin emredici hükümlerine uygun olmak koșuluyla, tarafların aralarında bu sözleșmeyi yapmalarına bir engel yoktur. İși paylașan ișçiler ayrı kısmi çalıșma yapan kișiler olarak kabul edilir. İș Kanunu Tasarısı'nda, iș paylaşımı ayrı ayrı düzenlenmemiș olup, ancak kısmi çalıșmanın bir türü olarak uygulanmasına tasarı ve mevcut kanun engel değildir.

\section{c. Kayan (Esnek) İș Süresi}

Esnek kısmi çalıșma türlerinin en eskilerinden biri olan kayan (esnek) iș süresi, günlük ișe bașlama ve iși bitirme zamanını veya belirli bir zaman dilimi içinde ortalama günlük çalıșma süresini așmadan günlük çalıșma süresi uzunluğunu da çalıșanların belirlediği bir çalıșma modeli olarak tanımlanabilir. Bu modelde, tüm iș görenlerin iș bașında ol- 
masını gerektiren temel bir süre vardır. Bu temel süre “asıl, sabit veya çekirdek zaman” olarak ifade edilir. İş gören, bu çekirdek sürenin dıșında istediği zaman ișe gelmekte, ara dinlenmesi ve paydosunu kendi belirlemektedir. Çekirdek zaman aralığı dıșında kalan çalıșma saatleri esnek zaman olarak adlandırılır. Kayan esnek iş sürelerinin uygulanmasının en önemli avantajları; ișe geç gelme ve devamsızlıkların azaltılması, iș görenlerin en verimli zamanlarında çalıșacak șekilde kendilerini ayarlayabilmeleri, ișe geliş-gidiș saatlerindeki farklılașma nedeniyle trafik sorununun azaltılmasıdır.

Kayan esnek iș sürelerinin uygulanmasının avantajları olduğu gibi gerek iş görenlere gerekse ișverene yüklediği bazı dezavantajları da bulunmaktadır. Bunlar; ișletmenin uzun süre açık olması nedeniyle enerji giderlerinin artması, üstlerin astlarıyla haberleșme sorunları yaşaması, ișlerin yetiștirilmesi konusunda doğabilecek anlașmazlıklardır. Kayan (esnek) iș sürelerinin uygulanması Almanya'da ilk defa 1960'larda görülmüștür. Daha sonraları diğer Avrupa ve İskandinav ülkelerine süratle yayılmıștır. Kayan (esnek) iș süresinin iki farklı modeli mevcuttur (Brewster vd., 1997). Bunlar, basit ve kayan iș süreleri modelleridir.

\section{i) Basit Kayan Iș Süresi Modeli}

Bu tür kayan iş süresi uygulamasında, önceden sabit olarak belirlenen günlük iș süresi içinde iș gören, çekirdek süre dıșındaki esnek sürede sadece ișe bașlama, ara dinlenmesi ve ișin bitiș zamanını kendisi belirler. Böylece iș görenin, çalıșmaya erken veya geç bașlayıp, iși erken veya geç bitirmesi kendi isteğine bağlı olur (TiSK, 1998).

\section{ii) Vasıflı Kayan Iss Süresi}

Vasıflı kayan iș süresinde, ișçi günlük çalıșma süresinin uzunluğunu da kısmen kendisi belirleyebilmektedir. Burada iş gören, çekirdek süresinde çalıșmak koşuluyla, günlük çalıșma fazlasını veya açığını belirli bir zaman dilimi içinde (hafta, ay) daha az ya da daha fazla çalıșmak suretiyle denkleștirme olanağına sahiptir. Bu șekilde iș gören, çalıșılmayan süreleri zaman içinde telafi edebilmekte veya fazla çalıșılan süreleri serbest zaman olarak kullanabilmektedir.

\section{d. Cağrı Üzerine Çalıșma}

Kısmi süreli çalıșmanın özel bir șekli olan çağrı üzerine çalıșma, önceden yapılan bir hizmet akdi uyarınca iș görenin ișveren tarafından çağrıldığında ișyerine gelerek çalıșmasıdır. Bu çalıșma modelinin temelinde ișletmeye esneklik sağlayarak, ișletmenin talep değișikliklerine uyumunu temin etme ihtiyacı vardır. Talebin az olduğu dönemlerde isteğe bağlı olarak iș sürelerinin azaltılması, talebin arttığı dönemlerde ise çağrı üzerine çalıștırmanın olanaklı hale gelmesi sağlanır. Ayrıca ekonomik durgunluk dönem- 
lerinde talebin ve üretimin azalması halinde çalıșma süreleri azaltılarak, iș görenlerin ișten çıkarılması bu model sayesinde önlenebilir.

Bu model genel olarak iki șekilde uygulanmaktadır. Illk olarak, iş görenler ve ișverenler belirli bir zaman dilimi içinde (hafta, ay, yıl) çalıșma süresinin ne kadar olacağını birlikte belirleyebilirler. Böylelikle ișverene, ișçinin iș edimini ne zaman yerine getireceğini çağrı yoluyla belirleyebilme olanağı tanınmaktadır. Ayrıca yapılan sözleșmeyle iș gören ne kadar süre çalıșacağını bilir. Diğer uygulama yönteminde ise çalıșılacak sürenin belirlenmesi tek taraflı olarak ișveren tarafından düzenlenir. İs görene ne kadar zaman önceden haber verileceği ve iș görenin her seferinde ne kadar süre çalıșacağı konuları ön plana çıkar. Almanya'da kapasiteye bağlı değișken iș süresi KAPOVAZ olarak da adlandırılan, çağrı üzerine çalıșma Alman İstihdamı Teșvik Yasasına göre, bu modellerden birincisine imkân tanımaktadır. Söz konusu yasaya göre, ișçi ile ișveren ișçinin hizmet edimini ișin uzunluğuna göre yerine getirmesini kararlaștırdıklarında, mutlaka iș süresini de belirlemek zorundadırlar. Böyle bir belirlemeye gidilmediği takdirde, tarafların 40 saatlik haftalık iș süresine karar verdikleri kabul edilir.

\section{e. Evde Calıșma}

Evde çalıșma 1996 tarihli 177 sayılı Evde Calıșma Sözleșmesinde, “Bağlı olduğu ișverene ait işyeri veya sair bir tesis dıșında evinde, ücret karșılığı ișverenin belirlediği bir malı veya hizmeti üreten kișinin çalıșması" șeklinde tanımlanmıștır. Uluslararası Çalıșma Örgütü'nün yaptığı tanımlama ise "Bir ișveren veya aracı için ișçinin seçtiği bir yerde, genellikle işçinin kendi evinde, ișveren veya aracının denetimi olmaksızın, bir sözleșme gereğince bir malın üretilmesi veya hizmetin sağlanması "biçimindedir (Alp ve Sönmez, 2011:10). Evde çalıșmanın ișçi ve ișveren açısından avantajları vardır. Özellikle ev kadınları için evde çalıșma, ev ișlerinin yapılması ve aile sorumluluklarının yerine getirilmesi açısından oldukça avantajlı bir çalıșma șeklidir. Ayrıca, evde çalıșma çocuklar ve özürlüler için de uygun bir çalıșma șeklidir. İșveren açısından ise evde çalıșma genel ișletme maliyetlerini düșürür. Evde çalıșma, zaman esnekliği yanında çalıșma yeri esnekliği de sağlar. Bu yönüyle evde çalıșma, esnek çalıșma biçimleri arasında en radikal olanı olarak nitelendirilir.

Gelișmekte olan ülkelerde geçmișten beri uygulanan bu çalıșma șekli; gelișmiș ülkelerde de yaygınlık kazanmaya bașlamıștır. Kısmi süreli çalıșmada olduğu gibi evde çalıșmada da en büyük çalıșan oranını kadınlar olușturmaktadır. Almanya, Yunanistan, İtalya, Hollanda, İspanya ve İngiltere evde çalıșmanın önem kazandığı ülkeler arasındadır. Avrupa Konseyinin bir araștırmasına göre Almanya, İtalya, Hollanda, İrlanda ve Yunanistan'da evde çalıșanların \%90-95'ini kadınlar olușturmaktadır. Bu oran, Fransa'da \%84, İspanya'da \%75, Ingiltere'de ise \%70'tir. Eurostat'a göre ise Avrupa'da 6,9 milyon kiși ile çalıșan nüfusun \%4,9'u evde çalıșmaktadır (Eyrenci ve Bakırcı, 2000: 28). 
Ülkemizde bu çalıșma modeli İș Kanununda özel olarak düzenlenmemekle birlikte uygulamada sıklıkla görülür. Bu çalıșma modeli İș Kanunu Tasarısında da yer almaz ancak uygulanmasına engel teșkil edecek bir madde yoktur. Ülkemizde evde çalıșma modeli, ilk olarak Güneydoğu Anadolu'da yașanan istihdam problemine çare bulmak amacı ile uygulamaya bașlatılmıștır. Daha sonra model Türk toplumunun geleneksel aile yapısına son derece uygun olduğu görülerek Türkiye'de uygulanmaya bașlanmıștır. Evde çalıșma modeli ülkemizde özellikle tekstil sektöründe yaygın olarak kullanılmaktadır. Eve parça bașı ücret karșılında iș verme, ülkemizde gizli ișsizliğin önüne geçilerek aktif olmayan aile bireylerinin ișgücüne kazandırılması açısından önemli bir fonksiyonu bulunmaktadır (Kuzgun, 2007: 856).

\section{f. Tele (Uzaktan) Çalıșma}

Bilgisayar ve iletișim teknolojisinin imkânlarının kullanılması sureti ile geliștirilen yeni çalıșma modellerinden birisi de tele çalıșmadır. Literatürde tele çalıșmanın tanımı üzerinde bir fikir birliği yoktur. Genel olarak merkez bürodan veya üretimin yapıldığı yerden uzak bir yerde yapılan, çalıșma șekli olarak tanımlatabiliriz. Bilgisayar ve iletișim teknolojisindeki gelișmeler sonucunda ortaya çıkmıștır. Uzaktan çalıșma telefon, faks makinesi, ev bilgisayarları ve internet kullanımı ile mümkün olur. Tele çalıșmanın karakteristik özellikleri șu șekilde sıralanabilir; iș, ișyeri dıșında ayrı bir yerde görülür. Bu yer ile esas ișyeri arasında elektronik iletișim araçları ile kurulmuş bir bağ vardır. İs programlanabilir bir araç vasıtası ile yapılır.

Tele çalıșma modelinin ișyeri ve çalıșan açısından bașlıca avantajları; esnek üretime olanak vermesi; ihtiyaç duyulduğu anda artan iș talepleri, tele-çalıșma ile dıșarıdan karșılanabilir. Dıș kaynak kullanımı; tele-çalıșmadan, dıș kaynak kullanımı yöntemi olarak da yararlanılabilir. Personel maliyetlerini düșürmesi; tele-çalıșma ile iș, proje bazında ve sonuç odaklı verildiği için çoğu zaman personel maliyetlerinde düșüș sağlanmaktadır. İşyeri ișletim giderlerini düșürmesi; ișyerinde personel çalıștırmaya bağlı olarak; kira, ofis ekipmanları, elektrik, su, ulașım, yemek, sağlık gibi birçok masraf kaleminde düșüș sağlanmaktadır. Esnek çalıșma saatlerinin uygulanabilirliği; kiși çalıșma saatlerini kendi intiyaçlarına göre ayarlayabilmektedir. Serbest iș kıyafetleri; kiși istediği kıyafetle çalıșabilmektedir. Performansa göre değerlendirme; kiși performansına göre iş sonuçları elde edecek ve karșılığını alacaktır. Bireysel maliyetlerde düșüș sağlanması; eğer firma tarafından karşılanmıyorsa ulaşım ve yemek masrafları azalır. İkametgâh yerinin serbestçe kararlaștırılmasının mümkün olması. Kadın, çocuk, sakat ve hükümlülere yeni iș imkânı yaratması gibi olumlu yönleri mevcuttur. Zamanın istenildiği gibi planlanmasına imkân verilmesidir.

Tele çalıșma modelinin ișyeri ve çalıșan açısından dezavantajları; statüsünün belirsizliği nedeniyle çalıșanlar sosyal güvencelerden yoksun kalabilir. Firmalar istenen nitelikte 
iș üretebilecek kișileri bulmakta zorluk çekebilir, bu da ișin sürekliliğini ya da kalitesini olumsuz yönde etkiler. Kurumsal bağlılık, bu tür çalıșanlardan herhangi bir kurumsal bağlılık beklemek olanaksızdır. Bu durum çalıșanların daha iyi koșullarda kısa sürede bașka ișlere geçmesine yol açabilir. Ayrıca, kurum kültürünü de olumsuz yönde etkiler. Tele çalıșma örgütsel öğrenmeyi azaltmaktadır. Bu yüzden firmaların temel faaliyetleri ile ilgili alanlarında bu tür çalıșmalardan kaçınılması önerilir. İș güvenliğinin az olması, tüm esnek çalıșma modellerinde olduğu gibi tele çalıșmada da iș güvenliği yeterli değildir. Ayrıca performans her zaman istenen düzeyde olmayabilir. Çalıșma saatlerinin esnekliği çok abartıldığında, bireyin doğal bio-ritminin dıșında bir çalıșma ve yașam düzeyine geçilebilir. İs görenin performansının izlenmesi ve ölçülmesinde zorluklar yaşanır. İsyerindeki sosyal paylașımın bulunmaması sonucu yabancılașma, tele çalıșmanın en büyük dezavantajı olarak görülür. Bazı kișilerin kișilik özellikleri itibariyle ekip çalıșmasından ziyade, tek bașına çalıșmaya daha uygun olduklarını ve bunların bu tür sorunları daha az yașadıklarını da göz ardı etmemek gerekir. Nitekim bu tür çalıșma en çok bu kișilik özelliklerine sahip olanlar tarafından tercih edilmektedir.

Pek çok AB ülkesinde merkezi ve yerel yönetimlerde uygulanmakta olan ve özel yasal düzenlemeler yapılan tele çalıșma modeline ilișkin olarak ülkemizde 2010 yılında İș Kanunun 14. maddesinde değișiklik yapmayı öngören 61. maddesine tele çalıșma eklenmiștir (Kandemir, 2011). Tele çalıșmanın dört farklı çalıșma șekilleri bulunmaktadır. Bunlar; evde büro, uydu büro, komșu büro ve gezici bürodur.

Evde Büro: Burada iș edimini görmekle yükümlü olan kiși, üstlendiği iși kendi evinde elektronik iletișim ağı ile yerine getirir. Bu çalıșmada bilgisayar donanımı evde bulunur, ev ile ișletme merkezi arasında bağlantı kurulur ve kișiler kendi evlerinde çalıșırlar. Çoğunlukla e-posta, ofis bilgisayarlarına bağlı bilgisayarlar, telefon ve faks makineleri kullanılarak gerçekleștirilir. İs görenlerin kullandıkları teçhizat kendilerine veya ișletmeye ait olabilir. Bu ișlere örnek olarak muhasebecilik, bilgisayar programcılığı gösterilebilir. Klasik anlamda evde çalıșmayla karșılaștırıldığında, evde büronun bütünüyle farklı bir dizi beceriyi, organizasyon biçimini gerektirdiği ve merkezdeki ișverenle değișik ilișkileri içerdiği görülür. Klasik evde çalıșma biçiminde ise daha çok el becerilerine dayalı ișler söz konusudur. Uydu Büro: Tele çalıșmanın bu șeklinde iș görme edimi ișletme dıșında tek iş gören tarafından gerçekleștirilmektedir. Uydu bürolar merkez bürodan uzak bölgelerde kurulan, ancak elektronik iletișim araçları ile merkezle her zaman ilișki içinde olan birimlerdir. Burada iș gören, ișletmenin personeli konumundadır ve bir istihdam biçimi olmasına karșın, ișletme yapısı içinde bağımlı iș ilișkisine dayanarak, ișverenin denetimi altında çalıșmaktadır. Amaç, ișletme dıșında kurulan merkezin söz konusu ișletmenin iș görenlerinin büyük çoğunluğunun ikamet ettiği bir bölgede kurulmasıdır. Bir uydu ofiste sadece tek bir firmadan iş görenler bulunur. Uydu ofislerdeki teçhizat, firma tarafından sağlanır. Bilgisayarlar, telefon, faks ve diğer teçhizat mevcut olduğundan iș görenler șehirdeki ana ofise gitmek zorunda kalmazlar. Komșu Büro: 
Tele çalıșmanın bu biçiminde bir kaç ișletme tarafından kurulan büro, aynı sektörde faaliyette bulunan ișletmelere elektronik iletișim araçları vasıtasıyla hizmet sunmaktadır. Komșu bürolar birkaç ișletmenin bir araya gelmesiyle kurulabileceği gibi, serbest çalıșan konumundaki kișilerce de kurulabilmekte ve faaliyetlerinden çeșitli ișletmeler yararlanabilmektedir. Bu durumda ișletmeler arasındaki ilișki ticaret hukuku kurallarına göre düzenlenir. Komșu büroların en önemli avantajı personel tașıma giderlerinden ve zamandan tasarruf sağlamasıdır. Ayrıca ișletmeler, șehir merkezleri dıșında uygun fiyatlarla kurdukları bürolardan ortak hizmet aldıklarında genel giderlerden de önemli ölçüde tasarruf etmektedir. Gezici Büro: Tele çalıșmanın bu şeklinde, bir șirket ya da ișyeri temsilcisinin iși ile ilgili diğer bölgelere yaptığı yolculuklarda videotekst gibi elektronik iletișim araçlarını kullanarak merkezle bağlantı kurması mümkün olur. Videotekst bir ekran ve telekomünikasyon șebekesine bağlı bir terminalin meydana getirdiği karșılıklı iletișimi gerçekleștiren bir sistemdir. Bu sistem yaygın olarak ișletme temsilcileri ile tamir, bakım, servis hizmetlerinde kullanılmaktadır.

\section{g. Ödünç İș İlișkisi}

Ödünç iș ilișkisi, ödünç veren ișveren, ișçi ve ișçiyi ödünç alan ișveren arasında kurulan hukuki bir ilișki olarak tanımlanır (Tuncay, 2003: 57). Ödünç iș ilișkisi, ișverenin iș yükünün azalması halinde, personelini ișten çıkarmak yerine ihtiyacı olan bașka bir ișletmeye geçici bir süre için vermesidir. Yine ișveren, mevsimlik ișlerde ve ihtisas gerektiren ișlerde olduğu gibi, geçici olarak duyduğu ișgücü ihtiyacını, diğer ișverenlerden ödünç olarak karșılayabilir.

Ödünç iș ilișkisinde üçlü bir ilișki mevcuttur bu ilișki; iș gören, iş görenin hizmet akdi ile bağlı olduğu ișveren (ödünç veren) ve geçici süre ile çalıștığı ișveren (ödünç alan) arasındadır. İş gören, ödünç alana karșı iș görme borcunu yerine getirmekle yükümlüdür. Ayrıca, onun verdiği talimatlara da uymak zorundadır. Ödünç alanın iș göreni gözetme sorumluluğu bulunur. Ücret ödeme borcu, aralarında hizmet akdi devam eden yani ödünç veren ișverene aittir. Ancak iș gören rıza gösterirse, ücret ödeme borcu geçici olarak ödünç alana da geçebilir. Bir ișverenin ilișkisi bulunduğu diğer bir ișveren gözetiminde güvendiği bir kișiyi kendi iș yerinde bulundurmak istemesi söz konusu olabilir. Holdingleșme ile ülkemizde de uygulanan bu istihdam türünde, bir holding, diğer sermaye sahipleri ile kurduğu bir șirkette, kuruluș ve faaliyete geçme safhalarında ya da kurulan șirkette veya işyerinde ortaya çıkan güçüklerin giderilmesinde kendine bağlı ve güvendiği üst kademe yöneticisinin görevlendirilmesini uygun görebilir. Yine üst kademe yönetici olarak yetiștirilmek istenen iș gören, geçici süre ile değișik faaliyetleri yürüten diğer șirketlerin emrinde çalıștırılabilir. Bir ișveren hizmet akdine göre istihdam ettiği ișçisini, geçici bir süreyle çalıștırmak üzere bașka bir ișverene verdiğinde, mevcut hizmet akdi sona ermez, devam eder. İş görenin geçici olarak emrinde çalıșacağı ișveren ile arasında bir hizmet akdinin kurulması söz konusu değildir. İlk ișveren, iș gören- 
den ișin görülmesinin talep edilmesi hakkını geçici süre ile ve iş görenin rızası ile ikinci ișverene devretmiș bulunmaktadır.

Ödünç iș ilișkisi çeșitli hukuk sistemlerinde incelendiğinde, bu tür ișçi istihdamının hemen her ülkede mevcut olduğu görülür. Bu üçlü ilișkinin hukuki yapısında bir ülkeden diğerine az çok farklılıklar vardır. Uygulanan tüm ülkelerde genel görüș, bașkasına ișçi verilmesinin ya da diğer bir deyimle ödünç iș gören istihdam edilmesinin gerek ulusal gerekse uluslararası düzeyde firmaların rekabet şansını artırdığıdır. Avrupa Birliği Çalıșma Müktesebatı'nda da düzenlenmiș olan ödünç iș ilișkisi ile ilgili hükümler; konseyin 91/383 sayılı “Belirli Süreli veya Ödünç İș İlișkili İsçilerin Sağlık Koruma ve Güvenliğin Düzeltilmesine Yönelik Önlemlerin Tamamlanması Hakkında Yönerge"si ile 96/71 sayılı “Hizmetlerin İfası Çerçevesinde İşçilerin (Bașka Bir Üye Ülkeye) Gönderilmesi Hakkında Yönerge"sinde yer almaktadır. 91/383 sayılı Yönergede, yönergenin amacını olușturan konuların yanında, ödünç iș ilișkisi hakkında genel kavram ve esaslar yönünden hükümlere, 96/71 sayılı yönergede ise ödünç iș ilișkisini kapsar hükümlere yer verilmektedir (Ekin 2002, 16). Türk çalıșma hayatında ödünç iș ilișkisi, 1960'lı yıllardan bașlayarak, sermaye yoğunlașmasıyla sayıları gittikçe artan șirket toplulukları ve holdinglerle çok kullanılan bir yol haline gelmiștir. Son dönemlerde ise ödünç iș ilișkisini mesleki faaliyet olarak yürütüp gelir sağlamayı amaçlayan girișimcilerin sayılarında artış olduğu tespit edilmiștir.

Ülkemizde çalıșma yașamının ihtiyaçlarının ortaya çıkardığı ve yaygınlaștırdığı bu ilișki türü hakkında Borçlar Kanunu madde 320/2' de yer alan hüküm dıșında herhangi bir düzenleme bulunmamaktadır. Borçlar Kanunu'nun 320. maddesi uyarınca "Hilafı mukaveleden veya hal icabından anlașılmadıkça işçi taahhüt ettiği șeyi kendisi yapmaya mecbur olup başkasına devredemez. Is sahibinin dahi hakkını bașkasına devredebilmesi aynı kayıtlara tabidir" (Ekin, 2002: 22). Bu yasal düzenlemeye göre ișveren iș yapma sorumluluğunu isteme hakkını kural olarak üçüncü kișiye devredemez. Ancak, anılan hükümde sözleșmeyle bu hakkın devrine olanak tanındığından bu yönde ișçinin rızasının bulunması halinde ödünç iș ilișkisi kurulabilir. İș görenin iș görme borcunu bașka bir ișverenin işyerinde yerine getirebilir. Borçlar Kanunu madde 320'de ifade edilen "halin icabı", örneğin ișyerinin devredildiği veya ișverenin kișiliğinin değiștiği hallerde ortaya çıkar ve bu gibi durumlarda ișin görülmesini isteme hakkı ișçinin rızasına gerek olmadan yeni ișverene geçer (Ekin, 2002: 22).

Ülkemizde ödünç iș ilișkisinin asgari șartlarının belirlenmesi için yasal düzenlemelerin yapılması gerekmektedir. İ Kanunu Tasarısında "Isveren (ödünç veren), yazılı rızasını almak suretiyle bir işciyi başka bir ișverene (ödünç alan) iş görme edimini yerine getirmek üzere geçici olarak verdiğinde ödünç iş ilișkisi kurulmuş olur"(Ekin, 2002: 25). ifadesi yer almaktadır. Ayrıca ödünç iș ilișkisinin AB'nin 91/383 ve 96/71 sayılı yönergelerinde, belirli süreli ve yazılı olarak yapılacağı, gerektiğinde yenilenebileceği belirtilmiș, 
bu yönergeler dikkate alınarak ödünç veren ve ödünç alan ișverenlerin yükümlülüklerine de yer verilmiștir.

\section{h. Yoğunlaștırılmıș İș Haftası Modeli}

Yoğunlaștırılmıș iș haftası, toplam haftalık iș süresinin, klasik olan 5 veya 6 ișgününe değil, daha az sayıda (3 veya 4) ișgününe sıkıștırılmak suretiyle dağıtılmasını ifade etmektedir. Örneğin, haftalık 40 saat olan çalıșma süresinin 4 iş gününe sıkıștırılarak diğer günlerin boș kalması sağlanır. Yoğunlaștırılmıș iș haftası, iș gören için daha fazla boș veya serbest zaman, ișe daha az gidip gelme, daha fazla mesleki eğitim imkânı vermektedir. İşveren bakımından ise, ișletmenin cari giderlerinin azaltılması, bakım-onarım ișlerinin ișin durmasına sebep olmadan yapılması gibi kolaylıklar sağlar (Göçer, 1994).

\section{i. Yıllık İș Süreleri Modeli}

Periyodik olarak yılın belirli dönemlerinde iș hacminin artı̆̆ı veya asgari düzeye indiği bazı işyerlerinde ortalama iș süresi, bir yıllık dönem için yapılan tam ve fazla çalıșmalar ile asgari çalıșma süreleri dengelenmek suretiyle hesap edilir. Bu tür çalıșmada iș görenin ücreti fiilen çalıșılan süreye göre değil, ortalama iș süresine göre ve daha ziyade sabit aylık ücret olarak belirlenmektedir. Bu șekilde asgari çalıșma dönemlerinde iș görenin ücretinde bir azalma olmamaktadır. Bu özellikle ülkemizde otomotiv ve tekstil sektöründe sıkça yașanan darboğazlar ya da talebin bir hayli arttığı dönemlerde uygulanması gereken bir yöntem olarak görülmektedir (TISK, 1999). Çalıșan kișinin tıpkı banka hesabı gibi, çalıștığı süreleri kaydettiği bir çalıșma saati hesabı bulunur. İs gören günlük çalıșılması gereken sürenin eksik veya fazla olan kısmını bu hesaba kaydeder. Belirtilen süre içerisinde iș gören, çalıșması sözleșmelerle belirlenen zamanı doldurur. Günlük veya haftalık çalıșma sürelerini kendi tercihine göre ayarlar. Çalıșma saati hesabı modellerinin farklı türleri geliștirilmiștir.

\section{j. Emekliliğe Yumușak Geçiș Modeli}

İs görenin birden bire emekliye ayrılmasına alternatif olan emekliliğe yumuşak geçiș modelinde, belirli bir yaștan sonra ișçi tedricen azalan sürelerde istihdam edilir. Bunun yanında, emeklilik yașına az kalan ișçiye kayan iş süreleri sisteminde çok daha geniş olanaklar tanınır. Bu șekilde emekliliğe yumușak geçisin amacı, iș göreni emeklilik șokundan kurtarmak ve aynı zamanda iș görenin yașlanmasına bağlı olarak azalan çalıșma gücüne uygun bir șekilde iș sürelerini azaltmaktır (Göçer, 1994). 


\section{k. Vardiya Modelleri}

Bir iș görenin çalıșma saatinin ișletmenin faaliyet gösterdiği zamandan kısa olması durumunda ya da tam tersine ișletmenin faaliyet gösterdiği süre çalıșanların çalıșma saatinden uzun ise personel planlamasında çalıșma saatlerinin düzenlenmesi zorlașır. Bu durumda vardiyalı çalıșma söz konusu olur. Vardiyalı çalıșma, ișin niteliği gereği sürekli çalıșılması gereken ișlerde geçmișten bu yana uygulanan çalıșma şeklidir. Diğer çalıșma modelleri ile kombine edilerek de uygulanmaktadır. Günümüzde iki veya üçlü vardiya sistemi yerine kayan (esnek) vardiya sistemleri uygulanmaktadır. Çok sayıda kısmi süreli vardiya grupları olușturarak bu grupların çalıșma süreleri birbiri ardına eklenmek suretiyle ișyerindeki vardiya çalıșmasında bütünlük sağlanır. Bu sistemde vardiyaların değișik uzunlukta belirlenebilmesi, ișletmenin günlük normal iş süresinin uzatılmasını sağlar. Vardiya sistemleri, özellikle işyerinde üretim kapasitesinde bir artıșın planlandığı dönemlerde ya da vardiya ișçilerinin de kısmi süreli çalıșmak istemeleri halinde yararlı olmaktadır. Esnek vardiya modelinde modelin esnekliği, iș görenlerin tercihlerinin, vardiyaların süresinde, yerinde ve dağılımında ne derecede dikkate alındığı ile ölçülür. AB ülkelerinde yoğun olarak kullanılan bu çalıșma yöntemi, ülkemizde de uygulanmaktadır. 1475 sayılı İș Kanunu ve bu Kanuna dayanılarak çıkartılan Tüzük, vardiyalı çalıșmanın usul ve esaslarını düzenlemiștir. İș Kanunu Tasarısı ile bu çalıșma sisteminin daha da esnekleștirilerek uygulanması mümkün olabilecektir.

Esnek vardiya modelleri denince genel olarak, ișletmedeki çalıșma zamanının birden fazla bașlama ve bitiș zamanları ile önceden belirlenen dağılım ve süreleri farklı olan parçalara ayrılması anlașılır. Böylece ișletmede çalıșılması gereken süre, aynı iş yerinde farklı iș görenler tarafından belirlenen aralıklarda paylaștırılarak çalıșma saatlerinin, ișverenin ihtiyaçları doğrultusunda uzatılması sağlanır. Çalıșma saati günün büyük bir bölümünü veya 24 saatini kapsayabilir. Vardiya sisteminin olușturulmasında çok sayıda uygulama biçimi mevcuttur. Bu sisteminin esnekleștirilmesi genellikle başka modellerle kombine edilmesi ile sağlanır. Örneğin vardiyaların bașlama ve bitiș zamanları değișken olabilir. Veya bir hesap açılmak suretiyle vardiyalarda iş görenlerin çalıșma sürelerindeki farklılıklar kaydedilerek belli bir zaman aralığında çalıșılan sürenin eșitlenmesi öngörülebilir. Bazı iș yerlerinde vardiya sürelerinde esneklik sağlanırken, çalışanların mutlaka iş yerinde bulunmaları gereken çekirdek zaman aralıkları tespit edilir.

Modelin en büyük avantajı ișletmenin çalıșma saatlerinin uzatılabilmesidir. Özellikle hizmet sektöründeki bazı ișletmelerin (hastane, ıșıl ișlem fırını bulunan ișletmeler) 24 saat çalıșmaları zorunludur. Pek çok ișletmede bu modelin uygulanması ile fazla mesai ücreti ödemeden kapasite kullanım oranı arttırılabilinir. Diğer avantajları sırasıyla (Korkusuz, 2005); ișletmelerde bulunan araç ve gereçlerin kullanımının maksimum düzeye çıkarılmasını sağlamak, teknolojik yöntemlerin gelișiminin sürekliliğini sağlamak, iletișim, sağlık, güvenlik, turizm ve ulașım gibi hizmet sektörlerinde toplumun genelinin 
taleplerinin karșılanmasına yardımcı olmaktır.

En büyük dezavantajı ise gece vardiyalarında iș görenin psikolojik ve fizyolojik yüklenmesinin artmasıdır. Bu dezavantaj vardiya dönüșümlerinin düzenlenmesi ile minimuma indirilmeye çalıșılmaktadır. Esneklik bakımından en önemli ölçü ise ișletmenin çalıșma saatleri ile ilgili ihtiyaçlarını karșılarken, iş görenlerin vardiyalar ile ilgili tercihlerinin modelde göz önüne alınmasıdır.

\section{Sonuç}

Esneklik, piyasa ve rekabet koșullarına daha fazla cevap vermek üzere katı kuralların yumuşatılarak taraflara daha çok serbestlik tanıyan bir çalıșma sisteminin benimsenmesidir. Çalıșma saatlerinin esnekliği ișveren ve iș görenlerin isteklerinin hangi ölçüde dikkate alındığı ile ölçülür. Geçmiș yılların aksine, yeni dönem ișverenlerin ortak görüșü “ișin nerede" yapıldığından ziyade, “ișin istenilen șartlarda” yapılıyor olmasına odaklanmaktadırlar. Esnek çalıșma modelleri sayesinde ișveren-ișçi-müșteri memnuniyeti döngüsünün maksimize olduğu rahatlıkla görülmektedir. Tüm dünya da hızla yaygınlașan esnek çalıșma modelleri, ülkemizde ise birkaç büyük kurumsal firma dışında çok fazla tercih edilmemektedir. Oysaki özellikle 4857 sayılı İs Kanununda yapılan değișikliklerin genel gerekçesinde teknolojinin yarattığı yeni koşullara uyum çabasına değinilerek, yeni teknolojilere bağlı olarak yeni çalıșma türlerinin ortaya çıktığı ve yaygınlașması gerektiği vurgulanmaktadır (Hatman, 2003).

Esnek çalıșma modellerinin șirketler ve çalıșanları tarafından tam anlamıyla bilinmemesi bu yeni çalıșma sisteminden uzak durulmasına sebep olmaktadır. Esneklik kavramının getirdiği önyargının aksine, mekân ve zaman kavramı bakımından bağımsızlık sağlaması durumunda, çalıșanların da șirkete daha fazla katkı sağladığı görülmektedir. Çalıșanın, çalıșma ortamında ki mutluluğu șirkete olan sadakatini da beraberinde getirmektedir.

Șirketlerin ișleyiși ve çalıșanların ihtiyaçları dikkate alınarak şirket bünyesine uygun esnek çalıșma modellerinden biri seçildiği takdirde çalıșanların verimliliğinin arttığı, iș değiștirmede ciddi azalmalar kaydedildiği, bununla beraber yeni personel alım maliyetlerinin azaldığı görülmektedir. Bu çalıșmada, ülkemiz için yeni bir kavram olan esnek çalıșma modelleri detaylı olarak incelenmiștir. Her bir modelin kendi içinde olușturduğu avantajlar ve dezavantajlar gerek șirket açısından gerekse çalıșan açısından; ayrı ayrı ele alınmıștır. Şirket kendine uygun esneklikte bir model seçerek yukarıda belirtilen avantajların yanında çalıșanlarının iș ve özel hayatlarının da dengede tutulmasına yardımcı olacaktır. 


\section{KAYNAKÇA}

Alp, Elif ve Alev Sönmez (2011) “ILO'nun 177 Sayılı Evde Çalıșma Sözleșmesi”, TÜHIS Is Hukuku ve Iktisat Dergisi, 23(5-6), s.16-27.

Brewster, Chris, Lesley Mayne ve Olga Tregaskis (1997) “Flexible Working in Europe: A Review of the Evidence", Management International Review Özel Sayı, 1997/1, s.85-103.

Centel, Tankut ve Sarper Süzek (2002) iș Hukuku, İstanbul: Beta.

Centel, Tankut (1992) Kısmi Calıșma, İstanbul: Kazancı Hukuk.

Crompton, Rosemary (2002) "Employment, Flexible Working and the Family"; The British Journal of Sociology, 53(4), s.537-558.

Duck, Jeanie Daniel (1999) “Changing Management”, MESS: Harvard Business Review.

Ekin, Nusret (2002) "Çağdaș İș Kanunu İhtiyacı”; Ișveren Dergisi, XL(12), s.26.

Eyrenci, Öner ve Kadriye Bakırcı (2000) Dünyada ve Türkiye'de Evde Calıșma ve Eve is Verme, İstanbul: İstanbul Ticaret Odası.

Göçer, İthan (1994) “İstihdam Hizmetlerinin Çeșitlendirilmesi ve Özel İstihdam Acentaları", İșveren Dergisi, 32(6), s.20-22.

Hatman, Ülkü (2003) Esnek Calıșma ve Endüstri llişkilerine Etkisi, Basılmamıș Yüksek Lisans Tezi, İstanbul: Marmara Üniversitesi Sosyal Bilimler Enstitüsü.

ILO (1993) World of Work. No:5.

Kandemir, Murat (2011) Iss Hukuku ve Sosyal Güvenlik Hukuku Açısından Tele Calıșma, Ankara: Legal.

Karakoyunlu, Erdoğan (2003) “Ya Esneklik Olmazsa..?”, İșveren Dergisi, TiSK Yayını, 41(5), s.7-8.

Kuzgun, İnci (2007) “Türkiye'de Firma Açısından Esnekliğe Dayalı İstihdam Stratejisi”, Journal of Yașar University, 2(8), s.841-861.

Korkusuz, Refik (2005) "Vardiyalı (Postalar Halinde) Çalıșma ve Türk İş Hukuku'ndaki Düzenlenmesi", Gazi Üniversitesi Hukuk Fakültesi Dergisi, 9(1-2), s.68-85. 
Köstekli, Șener (2000) Esneklik ve Sendikal Politikalar, Türk-Iș Yıllığı cilt 1.Ankara.

Mahiroğulları, Adnan (2005) Türkiye'de Issçi Sendikacılığı, İstanbul: Kitabevi.

TísK, (1999) Çalışma Hayatında Esneklik, Ankara.

Tiziano, Treu (1992) “Labour Flexibility in Europe”, International Labour Review, 131(45), s.497-512.

Tuncay, Can (2003) "İș Kanunu Tasarısı'ndaki Ödünç İș Illișkisi ve Eleștirisi”; Mercek Dergisi, 8(30), s.57.

Türk-İs (2003) 19. Olağan Genel Kurul Calıșma Raporu 1999-2003, Ankara.

Türk-İs (1998) 20. Olağan Genel Kurul Calıșma Raporu, Ankara.

Yavuz, Arif (1995) Esnek Calıșma ve Endüstri Ilişskileri' ne Etkisi, Ankara: Kamu İșletmeleri İsveren Sendikası. 


\section{BEYKOZ AKADEMI DERGISI YAYIN İLKELERI}

1. Beykoz Akademi Dergisi, 6 ayda bir yayınlanan, hakemli bir dergidir. Dergi, her yılın Haziran ve Aralık aylarında yayınlanır.

2. Beykoz Akademi Dergisi, İșletme, Lojistik ve Iktisat bașta olmak üzere, iktisadi ve idari bilimler konusunda eserler kabul eder.

3. Beykoz Akademi Dergisi, Türkçe ve İngilizce dillerinde yazılmıș eserleri kabul eder. Türkçe yayınlanan eserlerde normal özet dıșında İngilizce genișletilmiş özet sunulur.

4. Beykoz Akademi dergisinde yayınlanacak eserler makale (article) ve kitap incelemesi (book review) olmak üzere iki gruba ayrılır. Her iki gruptaki yazılar hakem değerlendirmesine tabidir.

5. Yayınlanması amacıyla dergiye gönderilecek eserler, daha önce hiçbir yerde yayınlanmamı veya gönderildiği tarih itibariyle yayınlanma amacıyla hakemlik sürecinde olmayan çalıșmalar olmalıdır.

6. Değerlendirme süreci, yazar tarafından eserin Beykoz Akademi Dergisi'nin resmi editör adresine elektronik yoldan iletilmesiyle bașlar. Bunun dıșında herhangi bir yoldan eser kabulü yapılmaz.

7. Beykoz Akademi Dergisi'nde yayınlanacak tüm makaleler, yazarın kimliğinden haberdar olmayan iki hakemin denetiminden (double-blind review) geçer. Hakemlerin raporları, hakemlerin kimlikleri saklı tutularak yazara iletilir ve gerekli görülen durumlarda yazardan düzeltmeler istenir. Hakemlik sürecinde giren bir eserin dergide yayınlanıp yayınlanmayacağına editör tarafından, hakemlik sürecinin tamamlanmasından sonra karar verilir.

8. Dergiye gönderilen yazıların ön değerlendirmesi editör tarafından, yazının teslim edildiği tarihten itibaren iki hafta içerisinde yapılır ve șekil șartlarını sağlamayan ya da konu bakımından Beykoz Akademi Dergisi'nin yayın kapsamıyla uyușmayan yazılar geri çevrilir. Eğer editör tarafından yazının șekil șartlarını sağladığı ve Beykoz Akademi Dergisi'nin yayın kapsamıyla uyuștuğu düșünülürse, hakemlik süreci bașlatılır ve yazara bu yönde bilgi verilir. Hakemler yazıyı değerlendirir ve raporlarını editöre sunarlar. Bu noktada yazının

a. Yayınlanmasının mümkün olmadığına,

b. Kapsamlı düzeltmelerle birlikte yayınlanabileceğine,

c. Küçük düzeltmelerle yayınlanabileceğine veya

d. Mevcut haliyle yayınlanabileceğine

karar verilmiş olabilir. Bu karar, anonim hakem raporlarıyla birlikte yazara iletilir. Eğer yazıda düzeltme istenmișse, kapsamlı düzeltmeleri tamamlamanın süresi bir ay, küçük düzeltmeleri tamamlamanın süresi iki haftadır.

9. Yazar, hakemlik sürecinin herhangi bir noktasında yazısını gerekçe göstermeksizin geri çekebilir. Hakemlik sürecini bașarılı biçimde tamamlayan eserler yayın așamasına gelir ve yazardan yayınlanması için son onayı alınır. Bu noktadan itibaren yazının telif hakları Beykoz Akademi Dergisi'ne geçer ve yazar tarafından geri çekilmesi olanaksız hale gelir.

10. Beykoz Akademi Dergisi'nde yayınlanan eserler için herhangi bir telif ücreti ödenmez.

11. Beykoz Akademi Dergisi, hiçbir şart altında makalelerin hakemlik sürecine sokulması ya da yayımlanması için yazarlardan ücret talep etmez.

12. Editörlük ya da hakemlik sürecinin herhangi bir noktasında intihal içerdiği tespit edilen eserler derhal, bu gerekçeyle reddedilir.

13. Beykoz Akademi Dergisi'ne yayınlanma amacıyla eser gönderen kișiler bu ilkeleri okumuș ve kabul etmiș sayılırlar. 


\section{BEYKOZ AKADEMI DERGISI'NDE YAYINLANACAK ESERLERDE ARANACAK OLAN ȘEKIL SARTLARI}

\section{Biçim ve Sunum}

a. Eserler Microsoft Word programının son sürümünde yazılmış olmalıdır.

b. Eserlerde başlığın altında yazar(lar)ın, Adı Soyadı bulunmalıdır. Birden fazla yazarın bulunması durumunda yazarlardan ismi ilk sıraya yazılacak olan yazar aynı zamanda makalenin sorumlu yazarı (corresponding author) olacaktır.

c. Yazar(lar)ın bağlı bulunduğu kurum, varsa akademik titr ve elektronik posta adresi ilk sayfanın dipnotlarında belirtilmelidir.

d. Eserin bașında, Türkçe ve İngilizce olarak 500'er kelimelik Özet ve Abstract sunulmalıdır. Özet ve Abstract'ın sonunda, 3-5 adet anahtar kelime, JEL kodlarıyla birlikte alfabetik sırayla verilmelidir.

e. Eserin başlığı, tamamı büyük harfle ve koyu yazılmalıdır. Eser içerisinde bașlıklar üç seviye olmalı ve așağıdaki örnekte görüldüğü gibi biçimlendirilmelidir. 3. alt seviyeden daha derin bașlık açılmamalıdır.

\section{ESER BAŞLIĞI}

\section{Bölüm Bașlığı}

\section{a. Alt bașlık}

\section{i) Madde}

f. Eserin tamamı, Calibri fontla, 11 punto, 1,15 satır aralığı ve paragraflardan sonra 10 nokta boșlukla yazılmalı, metnin tamamı sola yaslanmalıdır.

g. Eserlerde yer alacak tablolar ve sekiller kendi gruplarında ayrı ayrı numaralandırılmalıdır (Tablo 1, Tablo 2 vb.). Tablo ve sekil başlıklarının “ilk Harfleri Büyük" yazılmalıdır. Tablo başlıkları tabloların üstüne, șekil bașlıkları șekillerin altına yazılmalıdır. Özgün olmayan tablo ve sekillerde muhakkak obje altında kaynak gösterilmelidir.

h. Her türlü yazım ve noktalama konusunda Türk Dil Kurumu tarafından uygulanmakta olan güncel kurallar dikkate alınır.

\section{Metin İçinde Kaynak Gösterilmesi}

a. Beykoz Akademi Dergisi'nde yayınlanacak eserlerde kaynaklar dipnotlarda değil, metnin içerisinde gösterilir. En temel halinde bu gösterge yazarın soyadı, eser yılı ve kaynak gösterilen yerin eserdeki sayfa numarası seklinde yapılır (Boratav, 2010: 35).

b. Eğer aynı noktada birden fazla esere atıf yapılacaksa atıflar parantez içerisinde ve noktalı virgülle ayrılarak, yazarın soyadına göre alfabetik olarak sıralanır (Boratav, 2010: 35; Cem, 1974: 122).

c. Eğer iki yazarı bir kaynağa atıf yapılacaksa yazarların soyadı kaynaktaki sırayla 
verilir ve birbirlerinden "ve" bağlacı kullanılarak ayrılır (Hinderink ve Kıray, 1970: 140).

d. Eğer ikiden fazla yazarlı bir kaynağa atıf yapılacaksa, yazarlardan yalnızca birinin soyadının ardından “vd." (ve diğerleri) kısaltması kullanılır (Oyan vd., 2001: 25).

e. Aynı yazarın birden fazla eserine atıf yapılacaksa yazarın soyadı bir kez kullanılır ve atıf tarih sırasına göre yapılır (Boratav, 1986: 41; 2010: 35).

f. Aynı yazarın aynı yıl içerisinde yayınlanmıș birden fazla eseri kaynak gösteriliyorsa, bu eserler yılın sonuna küçük harf eklenerek sıralanır (Boratav, 1995a: 23).

g. Eğer yazarın ismi metin içinde geçerken atıf yapılıyorsa parantez içerisinde tekrar yazılmaz ve atıf, yazarın isminden hemen sonra değil, atıfın yapıldığı kelimenin sonrasına konur: Boratav'a göre (2010: 35).

h. İstisnai olarak, dipnotta atıf yapılacaksa, aynı kurallar uygulanır.

\section{Alıntılar}

a. Metin içinde yapılan her türlü alıntı, bir cümlenin parçası dahi olsa "tırnak içinde ve italik"yazılır ve uygun biçimde atıf yapılır.

b. İki tam cümleyi geçen alıntılar ayrı bir paragraf olarak, tırnak içine alınmadan ve 10 punto boyu ile italikyazımalıdır. Bu durumda atıf alıntının sonunda, aynı punto boyu ile ancak italik yapılmadan verilmelidir.

c. Blok alıntılardan kaçınılmalıdır.

\section{Dipnotlar}
a. Dipnotlar eser boyunca numaralandırılmalıdır
b. Dipnotlar, metin içinde bulunmasına gerek görülmeyen ancak ikincil öneme sahip olduğu için okuyucuya sunulması istenen konulara ayrılmalıdır.
c. Dipnotlarda hiçbir șart altında șekil, tablo vb. sunulmamalıdır.
d. Dipnotlar kesinlikle nokta ile biter.

\section{Kaynakça}

a. Kaynakça yazar soyadına göre sıralanmalı, aynı yazarın birden fazla eserinin kaynakçada yer alması durumunda eserler kendi içlerinde eskiden yeniye doğru sıralanmalıdır. Kaynakçanın her maddesinde yazar adı ve yıl kısmı kalın yazılır. Tarihsiz ya da yayın tarihi belirlenemeyen eserler "tarihsiz" șeklinde tarihlenerek yazarın en yeni eserinin altına yerleștirilmelidir. Yazarı bilinmeyen eserler “Anonim” isimli bir yazar tarafından yazılmıș gibi kaynak gösterilmelidir.

b. Kaynakça numaralandırılmamalıdır.

c. Kaynakçanın her maddesinin sonuna nokta konur.

d. Yayınlayan kurulușun adı verilirken bu ismin "Yayınevi”, "Press”, “Publishers" vb. bölümü yazılmaz.

e. Makale isimleri "Tırnak İçerisinde ve Baș Harfleri Büyük”, kitap isimleri Baş Harfleri Büyük ve Italikyazılır. 
f. İnternet üzerinden erișilen ve değișebilir kaynaklarda (haber portalları, blog yazıları vb.) muhakkak erișim tarihi belirtilir.

g. Makalelere yapılan atıflarda makalenin yayınlandığı periyodik yayının cilt ve numarası bu önekler olmadan belirtilir ikincisi parantez içine alınarak belirtilir, ardından sayfa aralığı "s." önekiyle verilir. Örneğin bir periyodik yayının 5. cildinin 10. sayısında 150 ile 200. sayfalar arasında yayınlanmıs olan bir makale 5(10), s.150-200 olarak gösterilir.

h. Her durumda yazarın ismi Soyad, Ad olarak yazılır. Iki yazar varsa isimleri orijinal kaynakta verildiği sıra ile verilir ve ikinci yazarın ismi "ve" bağlacından sonra Ad Soyad șeklinde yazılır. Üç veya daha fazla yazar olması durumunda aynı kural çerçevesinde, yalnızca sonuncu isim "ve” bağlacıyla ayrılarak yazılır. Birden fazla ismi ya da soyadı olan yazarlarda kısaltma kullanılmaz.

i. Bunun ötesinde, çeșitli kaynakların kaynakçada nasıl gösterilebileceği așağıda örneklenmiștir:

Kitap:

Boratav, Korkut (1986) Istanbul ve Anadolu'dan Sinıf Profilleri, Ankara: İmge.

Kitap, birden fazla yazarlı:

Kıray, Mübeccel ve Jan Hinderink (1970) Social Stratification as an Obstacle to Development: A Study of Four Turkish Villages, New York: Praeger.

Kitap, birinciden sonraki basımlar:

Boratav, Korkut (2010) Türkiye Iktisat Tarihi: 1908-2007, 12. Baskı, Ankara: İmge.

Çeviri kitap (gerektiğinde yukarıdaki biçimde baskı sayısı eklenerek):

Foster, William Zebulon (2011) Üc Enternasyonalin Tarihi, çev. C. Saday, İstanbul: Yazılama.

Dergiden makale:

Patnaik, Utsa (1979) “Neo-Populism and Marxism: The Chayanovian View of the Agrarian Question and Its Fundamental Fallacy"; The Journal of Peasant Studies, 6(49), s.375420 .

Derleme kitaptan makale:

Boratav, Korkut (1988) “Birikim Biçimleri ve Tarım”, Türkiye'de Tarımsal Yapılar (19232000)içinde (der. S. Pamuk ve Z. Toprak), s. 237-256, Ankara: Yurt.

Derleme kitabın kendisi (gerektiğinde yukarıdaki biçimde baskı sayısı eklenerek):

Pamuk, Sevket ve Zafer Toprak (der.) (1997) Türkiye'de Tarımsal Yapılar (1923-2000), Ankara: Yurt. 
Kurum tarafında hazırlanmıș rapor:

Devlet Planlama Teșkilatı (1963) 1. Beș Yıllık Kalkınma Planı 1963-1967, Ankara.

Konferansa sunulmuş bildiri:

Güler, Birgül Ayman (2002) “Dünya Bankası Proje Anlașmaları”, 2002 Tarım Haftası: Küreselleșme ve Türkiye Tarımı sempozyumunda sunulan bildiri, 7-8 Ocak 2002, Ziraat Mühendisleri Odası, Ankara.

Çalıșma Metni (Working Paper):

Șenses, Fikret (2007) Uluslararası Gelișmeler Ișığında Türkiye Yükseköğretim Sistemi: Temel Eğilimler, Sorunlar, Celişkiler ve Öneriler, Ankara: ODTÜ Ekonomik Araștırmalar Merkezi, ERC Working Papers No: 07/05.

Lisansüstü tez:

Önal, Nevzat Evrim (2007) 1980 Sonrası Devlet Politikalarının Tarımsal Dönüșüme Etkisi, Basılmamıș Doktora Tezi, İstanbul: Marmara Üniversitesi, Sosyal Bilimler Enstitüsü.

Internet adresinden makale:

Levidow, Les (2002) “Marketizing Higher Education: Neoliberal Strategies and CounterStrategies", http://oro.open.ac.uk/5069/2/LL_Marketising_HE.pdf, Erișim tarihi: 5 Ocak 2011. 



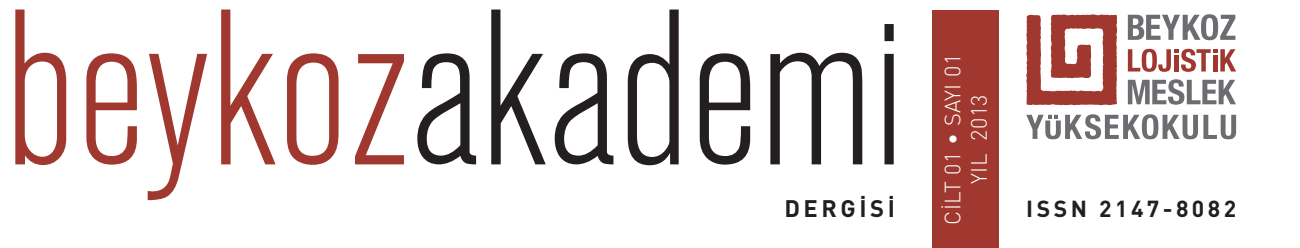

ÖRGÜTSEL ÖĞRENMENIN LOJISTIK

IȘLETMELERINE ETKILERI

KUZEY AFRIKA BÖLGESINE LOJISTIK

ÜS KURMANIN TÜRKIYE'NIN ULUSLARARASI

TICARETI AÇISINDAN ÖNEMI

SELECTION OF CONTAINER PORT WITH

FAHP-TOPSIS TECHNIQUE

TÜRKIYE'DE YAT VE MARINA ISLLETMECILIĞI: ISTIHDAM DEĞERLENDIRMESI IÇIN MEVCUT DURUM ANALIZI

FIZIKSEL AKTIVITE VE SAĞLIKLI BESLENMENIN BILIȘIM SEKTÖRÜNDE MASA BAȘINDA ÇALISTANLARIN SAĞLIĞINA ETKILERININ DEĞERLEMESI

TÜM YÖNLERIYLE ESNEK CCALIȘMA MODELLERI 